Portland State University

PDXScholar

$1-1-2011$

\title{
Analysis and Characterization of Debris Flows in November, 2006, Mount Adams, Washington.
}

Kendra Justine Williams

Portland State University

Follow this and additional works at: https://pdxscholar.library.pdx.edu/open_access_etds Let us know how access to this document benefits you.

\section{Recommended Citation}

Williams, Kendra Justine, "Analysis and Characterization of Debris Flows in November, 2006, Mount Adams, Washington." (2011). Dissertations and Theses. Paper 186.

https://doi.org/10.15760/etd.186

This Thesis is brought to you for free and open access. It has been accepted for inclusion in Dissertations and Theses by an authorized administrator of PDXScholar. Please contact us if we can make this document more accessible: pdxscholar@pdx.edu. 
Analysis and Characterization of Debris Flows in November, 2006,

Mount Adams, Washington

by

Kendra Justine Williams

A thesis submitted in partial fulfillment of the

requirements for the degree of

\author{
Master of Science \\ in \\ Geology
}

Thesis Committee:

Scott F. Burns, Chair

Andrew G. Fountain

Thomas C. Pierson

Portland State University

(C)2011 


\begin{abstract}
Debris flows caused by heavy rains occurred in November of 2006 on several Cascade volcanoes. Mt. Adams experienced debris flows in seven of eighteen drainages including Adams Creek, Big Muddy Creek, Lewis Creek, Little Muddy Creek, Muddy Fork, Rusk Creek and Salt Creek. Six debris flows occurred on the northeast side of the mountain. A landslide initiated one debris flow, three were initiated by heavy water flow and in channel landslides, and three were initiated by a coalescence of eroded channels (headless debris flows). Four pre-2006 debris flows were found in the Cascade Creek, Crofton Creek, Hellroaring Creek and Morrison Creek drainages. Every 2006 debris flow initiated in Quaternary glacial drift. Attributes of the drainages were investigated to determine differences between drainages with debris flows and those without. The upper basins of drainages with debris flows averaged $37 \%$ glacial coverage, $29 \%$ bedrock and $35 \%$ unconsolidated material. The upper basins of drainages without debris flows without averaged $12 \%$ glacial coverage, $63 \%$ bedrock, and $25 \%$ unconsolidated material. All of the drainages with debris flows were directly connected to a glacier, opposed to only $36 \%$ of the drainages without debris flows. Drainages with debris flows averaged $18 \%$ slopes above $33^{\circ}, 10 \%$ vegetation, a gradient of 0.38 , a Melton's Ruggedness Number of 0.62 , an average annual rainfall of $2.16 \mathrm{~m}$, and $-52 \%$ glacier lost between 1904-2006. The upper basins of drainages without debris flows averaged $11 \%$ slopes above $33^{\circ}, 18 \%$ vegetation, a gradient of 0.31 , a MRN of 0.58 , an
\end{abstract}


average annual rainfall of $2.38 \mathrm{~m}$, and $-41 \%$ glacier lost between 1904-2006. A multiple logistic regression was performed to determine factors with highest influence on predicting the probability of a debris flow. Influencing factors were percent glacial coverage and average annual rainfall. They predicted the 2006 debris flows with an $89 \%$ accuracy rate. This model was used to produce a debris flow hazard map. Due to the number of Cascade volcanoes that experienced debris flows as a result of the November 2006 storm, data of this type could be combined from multiple mountains to construct a general Cascade Mountain debris flow hazard model. 


\section{Acknowledgements}

First, I would like to thank my family for encouraging my study of geology and their constant support while finishing this project, even coming into the field with me when field assistants weren't available. Also continuously supportive have been Allen Matasy, and my lifelong friends, Kiah Bray, Lauren Clark, Tonya Corning, Emily Davis, and Maria Grompe.

I would like to thank my advisor, Scott Burns, for his encouragement and infectious passion in this field. Also my hardworking field assistants, Stacy Smith and Geoff Kahl, deserve recognition for their exertions and friendly support in the wilderness. I would also like to acknowledge Danielle Sitts, for her work collecting Mount Adams glacier data.

Darryl Lloyd was the first in the field for this project taking fabulous photos, making keen observations and collecting valuable data. Without this information I would not have known where to begin tackling this project so for this I am very thankful.

To Geoff McCarthy, who generously flew me and my parents in his plane not only around Mt. Adams twice but also around Mt. Saint Helens, an ecstatic thank you. We got amazing photos, and I don't think I will ever forget that experience.

I'm very appreciative of my committee members, Andrew Fountain and Tom Pierson, for their valuable time and input. I would also like to acknowledge Will Conley, of the Yakama Nation Fisheries Project, who had great advice and knowledge about the Yakama portion of Mt. Adams. 
Finally, a large thank you to the Mazamas organization for the student research grant from 2009 that made much of the field work for this project possible. 


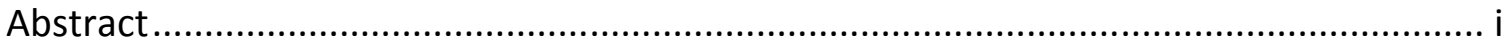

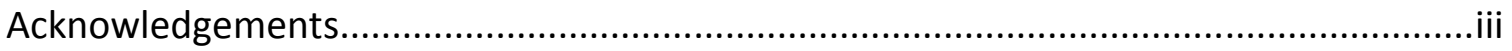

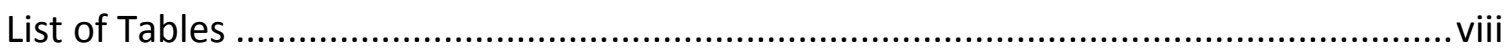

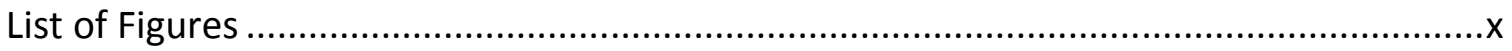

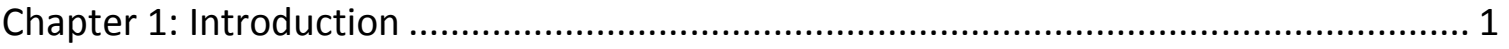

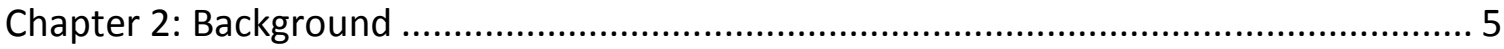

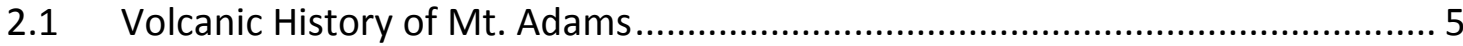

2.2 Mt. Adams: Landslides, Lahars, and Debris Flows ........................................ 6

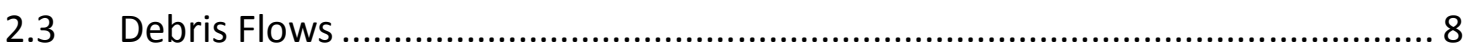

2.3.1 Debris Flow Behavior .......................................................................... 8

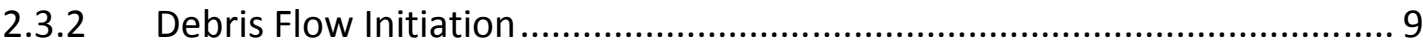

2.3.3 Debris Flow Producing Basins: Transport Limited or Weathering Limited. 11

2.3.4 Debris Flow Hazard Modeling ................................................................. 11

2.4 Other Cascade Mountain Debris Flow Research....................................... 13

2.5 Madden - Julian Oscillations and the November 2006 Storm ........................ 15

2.6 Damages in the Gifford Pinchot National Forest .......................................... 17

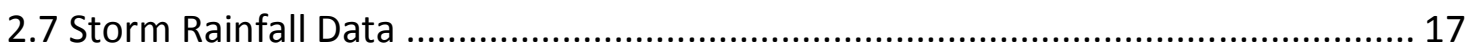

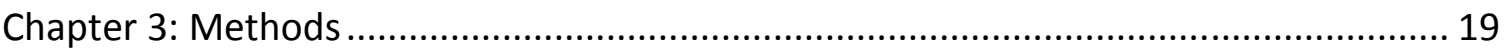

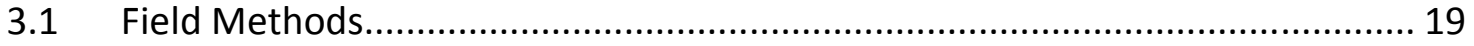

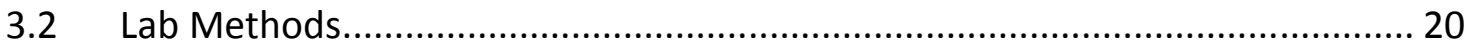

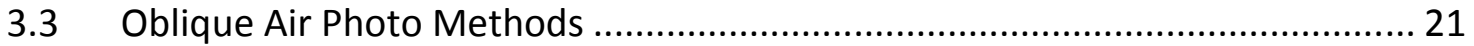

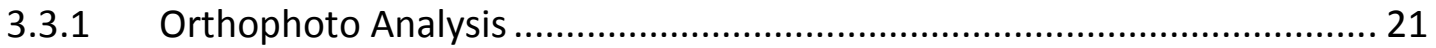

Oblique Air Photo Analysis................................................................... 22

3.4 GIS Evaluation of Basin Attributes ............................................................ 23

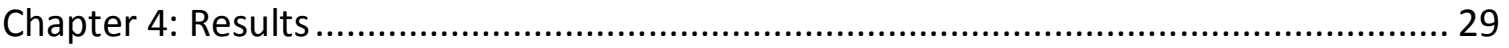

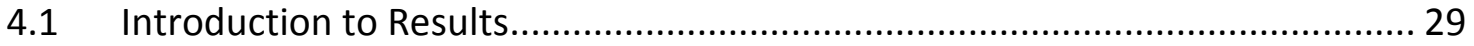

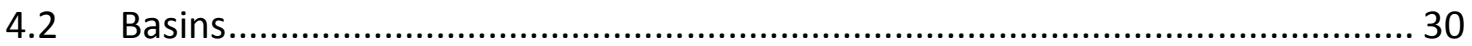

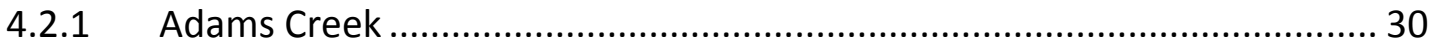

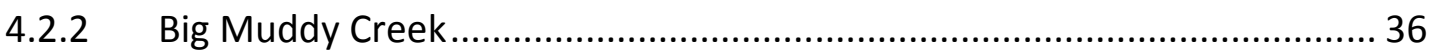

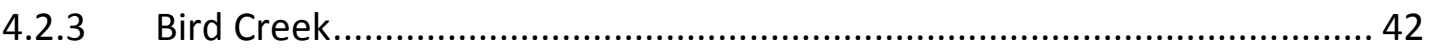




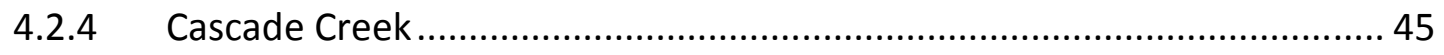

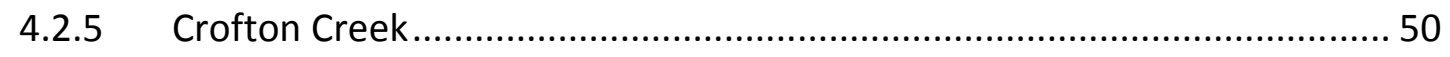

4.2.6 East Fork.......................................................................................... 54

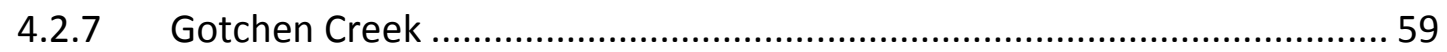

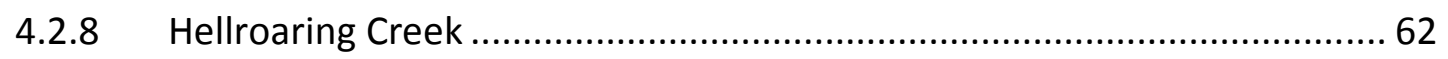

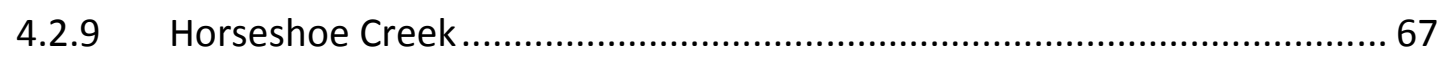

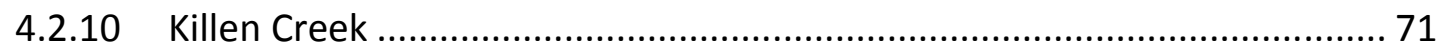

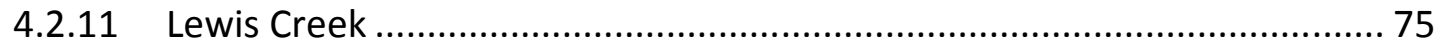

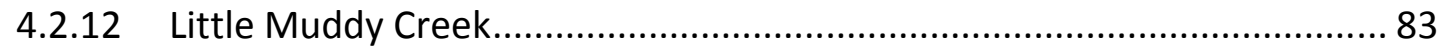

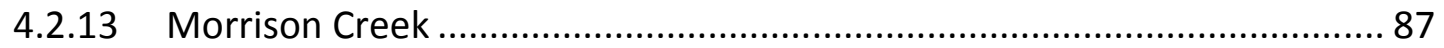

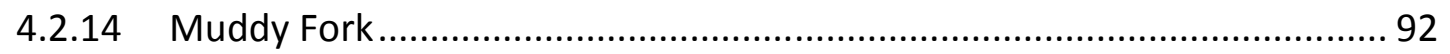

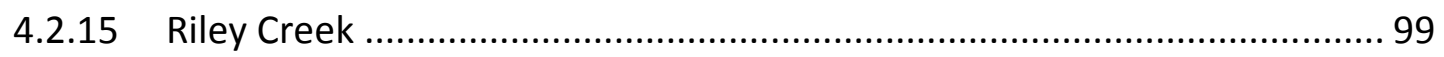

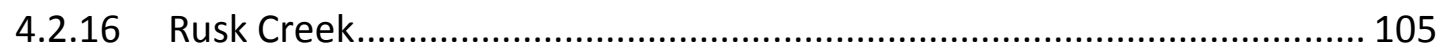

4.2.17 Salt Creek ...................................................................................... 111

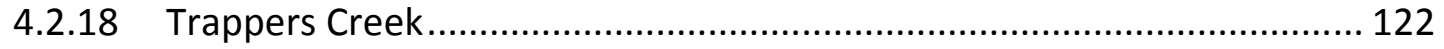

4.3 Summary of Results.............................................................................. 125

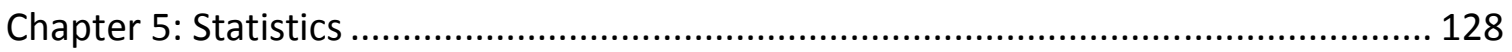

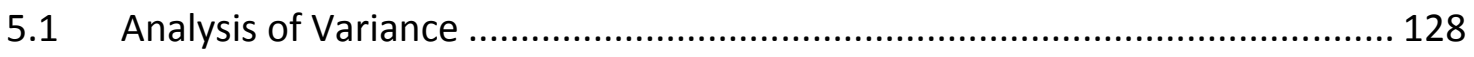

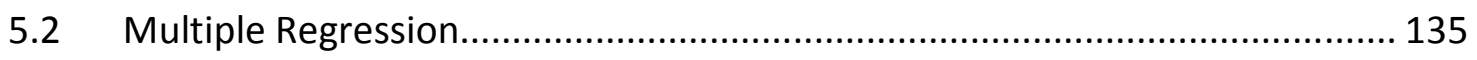

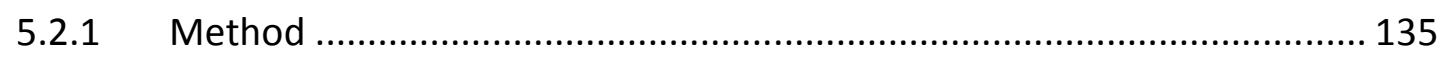

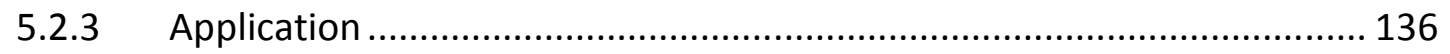

5.2.4 Regression with combined Mt. Adams and Mt. Hood Data ..................... 143

5.3 Summary of results of statistical analysis ...................................................... 149

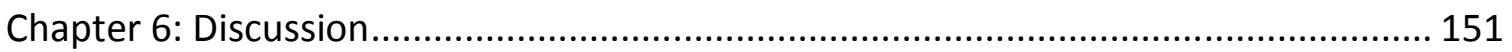

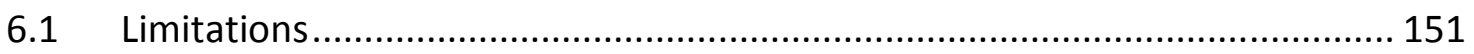

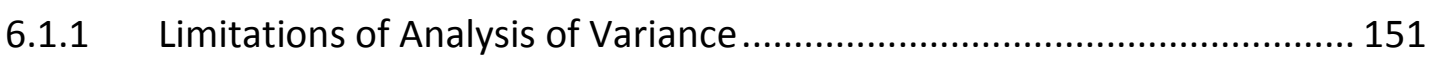

6.1.2 Limitations of Multiple Logistic Regression ........................................... 151

6.1.3 Limitations of the Wald Test.................................................................... 153

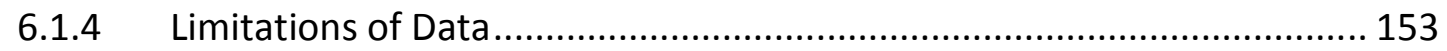

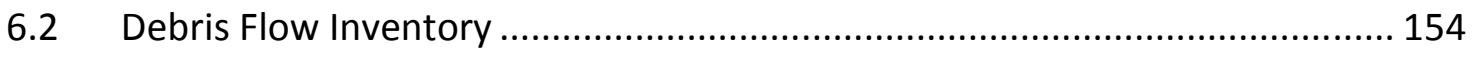

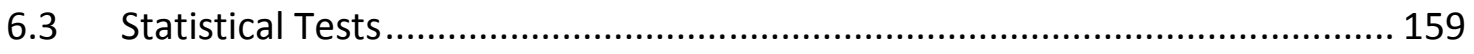




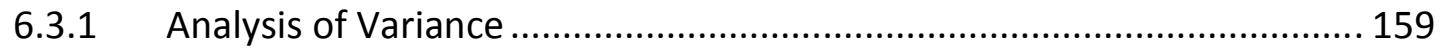

6.3.2 Multiple Logistic Regression .............................................................. 160

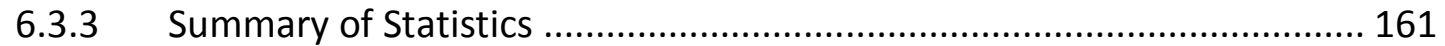

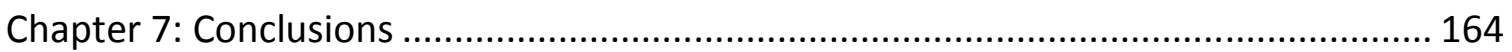

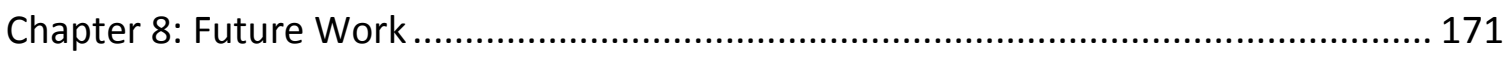

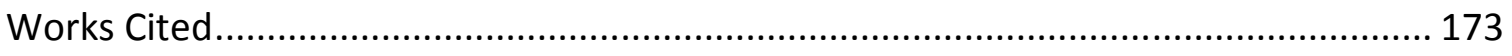

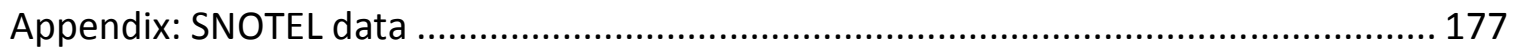




\section{List of Tables}

Table 1: Particle size distribution and classification of soil samples

Table 2: Adams Creek sieve results, Sample 106 subsets 1, 2 and 3. See Table 1 for exact

size definitions. Bottom row holds the average values....................................... 32

Table 3: Adams Creek Drainage Basin attributes. ..................................................... 36

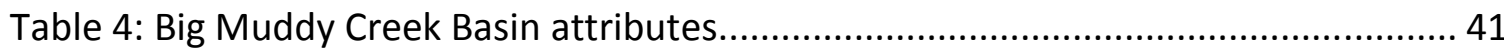

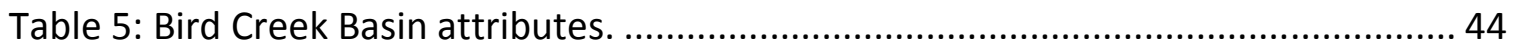

Table 6: Cascade Creek sieve results, sample 95 subsets 1, 2 and 3. See Table 1 for exact size definitions. Bottom row holds the average values.......................................... 48

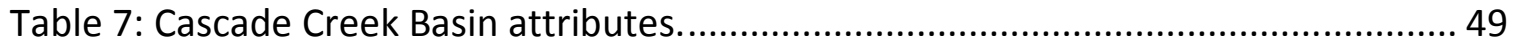

Table 8: Crofton Creek Drainage Basin Attributes......................................................... 54

Table 9: East Fork sieve results, sample 128 subsets 1, 2 and 3. See Table 1 for exact size definitions. Bottom row holds the average values............................................ 57

Table 10: East Fork Drainage Basin attributes ............................................................... 58

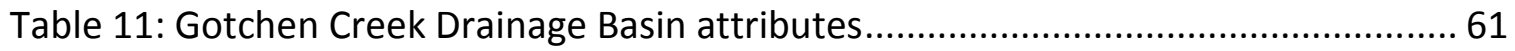

Table 12: Hellroaring Creek sieve results, sample 102 subsets 1, 2 and 3. See Table 1 for exact size definitions. Bottom row holds the average values. ............................. 65

Table 13: Hellroaring Creek Drainage basin attributes................................................ 66

Table 14: Horseshoe Creek sieve results, sample 91 subsets 1, 2 and 3. See Table 1 for exact size definitions. Bottom row holds the average values. ...............................69

Table 15: Horseshoe Creek Drainage s ....................................................................... 71

Table 16: Killen Creek sieve results, sample 127 subsets 1, 2 and 3. See Table 1 for exact size definitions. Bottom row holds the average values................................... 73

Table 17: Killen Creek Drainage Basin attributes.......................................................... 75

Table 18: Lewis Creek sieve results, sample 111 subsets 1, 2 and 3 and sample 116 subsets 1, 2, and 3 (respectively). See Table 1 for exact size definitions. Bottom

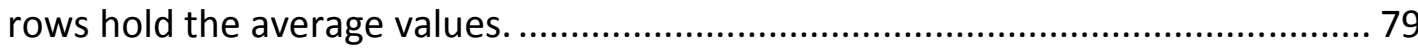

Table 19: Lewis Creek Drainage Basin attributes.................................................... 82

Table 20: Little Muddy Creek Drainage Basin attributes ............................................. 86

Table 21: Morrison Creek sieve results, sample 140. See Table 1 for exact size

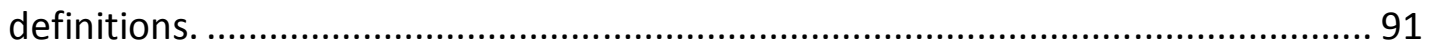

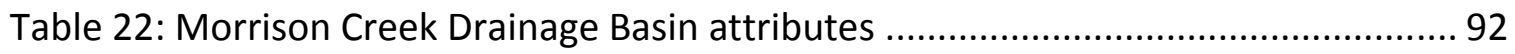

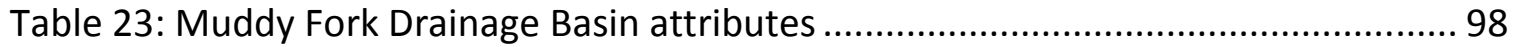

Table 24: Riley Creek sieve results, sample 113 subsets 1, 2 and 3. See Table 1 for exact

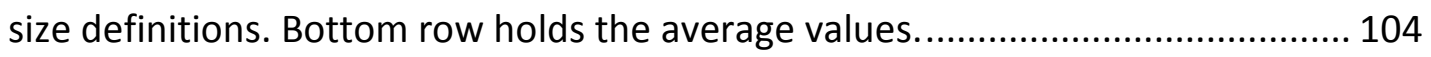

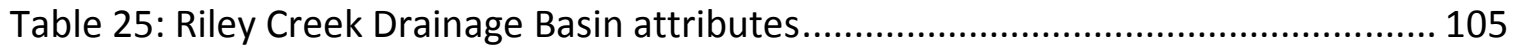

Table 26: Rusk Creek Drainage Basin attributes........................................................ 109

Table 27: Salt Creek sieve results, sample 140. See Table 1 for exact size definitions. . 120

Table 28: Salt Creek Drainage Basin attributes ....................................................... 121

Table 29: Trappers Creek Drainage Basin attributes ................................................. 124 
Table 30: Drainage groupings for statistical analysis based on 2006 debris flow occurrence.

Table 31: Results of ANOVA tests of basin attributes grouped by debris flow occurrence.

Table 32: Raw data used for the Logistic Regression.

Table 33: Normalized data used for the Logistic Regression.

Table 34: Results of the initial regression, before any variables were removed.

Table 35: Results of the Wald Test for the coefficients after each regression and subsequent removal of the least significant variable. Least significant value is shown in red for each regression.

Table 36: Results of the final regression showing the coefficients for the last two predictor variables.

Table 37: Results of the model (Equation 7) made by multiple logistic regression. Drainages with values higher than .5 are bolded. Known $Y$ is occurrence of debris flow as found by this study.

Table 38: Attributes and raw data for the combined multiple regression analysis. ...... 144

Table 39: Normalized data for the combined regression analysis. .............................. 145

Table 40: Result of the first regression of the combined Mt. Adams and Mt. Hood data, before any variables were removed. 146

Table 41: Combined regression results of the Wald Test for the coefficients after each regression and subsequent removal of the least significant variable.

Table 42: Results of the final regression showing the coefficients for the last two predictor variables for the combined Mt. Adams and Mt. Hood data, $\mathrm{X}_{5}$ which is connection to the glacier and $X_{6}$ which is percent glacial coverage in the upper basin.

Table 43: Results of the combined model with data from Mt. Adams and Mt. Hood. Drainages with values higher than .5 are bolded.

Table 44: Summary of statistical testing results for this study and for Pirot (2010)..... 150 Table 45: Overall grain size analysis results grouped by occurrence of 2006 debris flow. 


\section{List of Figures}

Figure 1: The northwest face of Mt. Adams taken from the air in September of 2010.... 1

Figure 2: Major Cascade Range volcanoes. Figure from Topinka (1997). ........................ 2

Figure 3: Madden - Julian Oscillation weather pattern before heavy precipitation occurs.

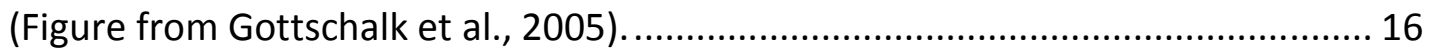

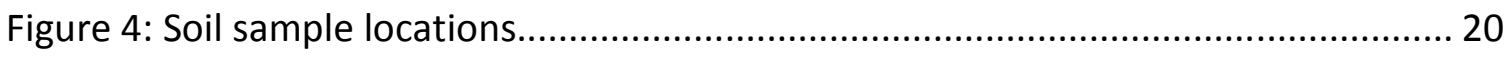

Figure 5: Location map of drainages on Mt. Adams displayed over the 10 m DEM....... 29

Figure 6: Map of Adams Creek Drainage. Black numbers are trail and road indicators,

black numbers with white halos refer to GPS points. Callout label points to the area

referred to as 'The Narrows' .................................................................................... 31

Figure 7: Adams Creek debris flow deposit from the Pacific Crest Trail looking northeast.

Photo taken by Darryl Lloyd on August 17, 2007................................................. 33

Figure 8: Sandy mud coated boulder deposit in the Adams Creek Drainage. Photo taken

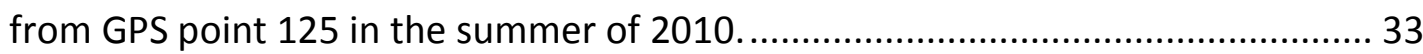

Figure 9: "The Narrows" of Adams Creek Drainage looking northwest with Mt. Rainier in

the background. Photo taken from GPS Point 104 in the summer of 2010............. 34

Figure 10: Collapsed moraine in the upper Adams Creek Drainage. Photo taken by Darryl

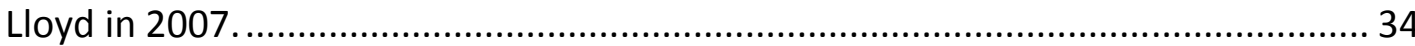

Figure 11: Initiation zone for Adams Creek Drainage. Photo taken during the summer of

2010 from GPS point 105......................................................................... 35

Figure 12: Map of Big Muddy Creek Drainage. Black numbers are trail and road indicators, and black numbers with white halos refer to GPS points. Initiation area includes a broad area of many small channels................................................. 37

Figure 13: Middle section of the Big Muddy Creek channel just below the upper canyon. View is to the west. Photo taken by Darryl Lloyd on October 14, 2007.................. 39

Figure 14: Big Muddy Creek debris flow channel just below the Klickitat Glacier. Photo taken by Darryl Lloyd on October 13, 2007............................................................. 39

Figure 15: Big Muddy Creek channel enlarged after debris flow. Photo taken by Darryl Lloyd looking south from Battlement Ridge 7/23/2007..................................... 40

Figure 16: Oblique air photo showing the Big Muddy Creek (left) Initiation Zone as well as the Rusk Creek (right) initiation zone. Areas of coalescence are circled in red, drainage labels are in black with black arrows pointing down slope. Photo taken September 30, 2010

Figure 17: Map of Bird Creek Drainage. Black numbers are trail and road indicators, black numbers with white halos refer to GPS points.

Figure 18: Photo of Bird Creek Drainage. Typical low gradient and abundant vegetation is visible. Photo taken during the summer of 2009.

Figure 19: Map of Cascade Creek Drainage. Black numbers are trail and road indicators, black numbers with white halos refer to GPS points. 45 
Figure 20: Sandy mud coasted boulder deposit in the lower Cascade Creek Drainage. Vegetation on the stream banks is also visible. Photo taken in the summer of 2009.

Figure 21: Boulder levee in the Cascade Creek Drainage. Photo taken during the summer of 2010. 48

Figure 22: Map of Crofton Creek Drainage. Black numbers are trail and road indicators, black numbers with white halos refer to GPS points. 50

Figure 23: Photo of the Crofton Creek Drainage at GPS point 16. Older looking channel incision and bank vegetation is visible. Photo taken during the summer of 2009. 52

Figure 24: Photo of the Crofton Creek Drainage at GPS point 20 where debris flow activity from Salt Creek spilled over the ridge. Down trees with bark ripped away are visible in the foreground. Photo was taken during the summer of 2010......... 53

Figure 25: Map of East Fork Drainage. Black numbers are trail and road indicators, black numbers with white halos refer to GPS points 55

Figure 26: An alpine meadow in the East Fork Drainage at 2,100 m known as "High Camp". Photo taken in September, 2010. 57

Figure 27: Map of Gotchen Creek Drainage. Black numbers are trail and road indicators, black numbers with white halos refer to GPS points. 59

Figure 28: Dry creek in the Gotchen Creek Drainage. Photo taken during the summer of 2009.

Figure 29: Map of Hellroaring Creek Drainage. Black numbers are trail and road indicators, black numbers with white halos refer to GPS points.

Figure 30: View across Hellroaring Creek. Some debris flow incision fresh channel collapse are visible in several locations. Red Arrow points out most obvious area. Photo taken during the summer of 2010.

Figure 31: Oblique air photo of Hellroaring Creek. Red arrow points out incision seen in Figure 30. Channels are visible in the lower right of the photo. Photo taken September $30^{\text {th }}, 2010$. 65

Figure 32: Map of Horseshoe Creek Drainage. Black numbers are trail and road indicators, black numbers with white halos refer to GPS points.

Figure 33: Stream Crossing in the lower Horseshoe Creek Drainage. Photo taken during the summer of 2009

Figure 34: Upper Horseshoe Creek Drainage looking to the northwest. Photo taken during the summer of 2010.

Figure 35: Map of Killen Creek Drainage. Black numbers are trail and road indicators, black numbers with white halos refer to GPS points. ......................................... 72

Figure 36: Upper Killen Creek Drainage. Photo taken during the summer of 2010........ 74

Figure 37: Map of Lewis Creek Drainage. Black numbers are trail and road indicators, black numbers with white halos refer to GPS points. ....................................... 76

Figure 38: Lewis Creek Drainage at the crossing with Trail 9. Vegetated channel sidewalls

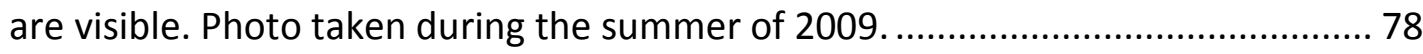


Figure 39: Collapsed moraine in the upper Lewis Creek Drainage Basin. Photo taken

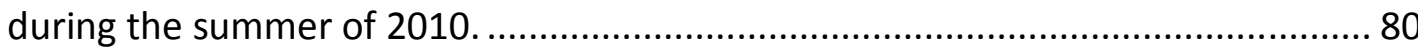

Figure 40: Area of water pooling in the upper Lewis Creek Drainage. Photo taken during the summer of 2010 .

Figure 41: Red Arrow points out a scarp in the upper Lewis Creek Drainage. Sample 116 was taken to the left (upstream) of this scarp. Photo taken during the summer of 2010.

Figure 42: Oblique air photo of the Adams Creek, Lewis Creek and Riley Creek drainages. The red circle is the initiation area and the yellow oval is where the flow crossed in to Riley Creek. The green outline is the affected area. The black arrows point downs slope. Photo taken September 30 ${ }^{\text {th }}, 2010$

Figure 43: Map of Little Muddy Creek Drainage. Black numbers are trail and road indicators, black numbers with white halos refer to GPS points.

Figure 44: Oblique air photo of the Little Muddy Creek Drainage. The red circle shows the eroded upper channels that coalesce lower in the drainage. Black arrows point down slope. Photo taken September $30^{\text {th }}, 2010$. 84

Figure 45: Oblique air photo of the Little Muddy Drainage. This photo shows another angle of Figure 44. Photo taken September $30^{\text {th }}, 2010$.

Figure 46: Map of Morrison Creek Drainage. Black numbers are trail and road indicators, black numbers with white halos refer to GPS points.

Figure 47: Morrison Creek Drainage at the crossing with Trail 9. Photo taken during the summer of 2009. 89

Figure 48: Upper Morrison Creek Drainage. Photo taken during the summer of $2010 \ldots 89$

Figure 49: Upper Morrison Creek Drainage. Red circle shows moraine with a 'V' shaped incision. Photo taken during the summer of 2010 ............................................ 90

Figure 50: Sandy-mud coated boulders in the upper Morrison Creek Drainage. Although very indicative of a recent debris flow, the lack of other recent defining characteristics made the conclusion that this drainage did not experience a 2006 debris flow. Photo taken during the summer of 2010.

Figure 51: Map of Muddy Fork Drainage. Black numbers are trail and road indicators, black numbers with white halos refer to GPS points.

Figure 52: Muddy Fork drainage at GPS point 76. Photo taken during the summer of 2009.

Figure 53: Muddy Fork Drainage at GPS point 76 along Trail 114. Photo taken during the summer of 2009 95

Figure 54: Muddy Fork Drainage with channel incision. Photo taken during the summer of 2009. 96

Figure 55: Upper Muddy Fork Drainage, incision visible looking through the gap in the moraine in the middle of the photo. Photo taken during the summer of 2009. .... 97

Figure 56: Oblique air photo of the Muddy Fork drainage. Landslide scarp visible at black arrow. Photo taken September $30^{\text {th }}, 2010$. 
Figure 57: Map of Riley Creek Drainage. Black numbers are trail and road indicators, black numbers with white halos refer to GPS points.

Figure 58: Small stream in the Riley Creek Drainage. Photo taken during the summer of 2009.

Figure 59: Riley Creek drainage at the crossing with the Pacific Crest Trail. Photo taken during the summer of 2009. 101

Figure 60: Ragged downed log in a debris flow deposit in the Riley Creek Drainage. This deposit came from a debris flow that initiated in the Lewis Creek Drainage. Photo taken during the summer of 2009.

Figure 61: Debris flow deposit in the Riley Creek Drainage. This deposit came from a debris flow that initiated in the Lewis Creek Drainage. Photo taken during the summer of 2009.

Figure 62: Photo of the upper Riley Creek Drainage. Photo taken during the summer of 2009 103

Figure 63: Map of Rusk Creek Drainage. Black numbers are trail and road indicators, black numbers with white halos refer to GPS points. .......................................... 106

Figure 64: Several channels of debris flow action at 2,073 m elevation in the Rusk Creek Drainage. Photo taken by Darryl Lloyd 7/23/2007.

Figure 65: Middle branch of Rusk Creek at 2,100 $\mathrm{m}$ in elevation. Photo taken by Darryl Lloyd on July 23, 2007. 108

Figure 66: Oblique air photo of the upper Rusk Creek Drainage. The red circle indicates several eroded channels that coalesce at a lower elevation. Black arrows point down slope. Photo taken September $30^{\text {th }}, 2010$.

Figure 67: Map of Salt Creek Drainage. Black numbers are trail and road indicators, black dots are GPS points. 110

Figure 68: Close up map of Upper Salt Creek Drainage. Black numbers are trail and road indicators, black numbers with white halos refer to GPS points.

Figure 69: Cascade Creek Swamp, where the Salt Creek debris flow ended raising the water level by around a meter. Photo by Darryl Lloyd in 2007.

Figure 70: View of Cascade Creek Marsh, the end of the Salt Creek Debris Flow. Photo taken by Darryl Lloyd in 2007.

Figure 71: Salt Creek Debris Flow deposits in the lower Salt Creek Drainage. Photo taken by Darryl Lloyd in 2007.

Figure 72: Lower Salt Creek Drainage showing run up height on the side of the channel in the background. Photo taken by Darryl Lloyd on September 23, 2007. 115

Figure 73: Salt Creek Drainage at GPS point 21. Photo taken during the summer of 2010

Figure 74: Salt Creek Drainage at GPS point 23. Photo taken during the summer of 2009

Figure 75: Salt Creek Drainage at GPS point 22. Photo taken during the summer of 2009. 
Figure 76: Melting permafrost exposed by the Salt Creek Debris Flow of November, 2006. Layer shows lahar deposit overlying glacial till overlying old glacial ice. Photo taken by Darryl Lloyd on August 30, 2007.

Figure 77: Salt Creek Debris Flow looking South. Photo taken from GPS point 81 in September 2009

Figure 78: The Salt Creek Debris Flow looking up through "The Breach" at the initiation zone. Photo taken from GPS point 81 in September, 2009.

Figure 79: View of Salt Creek Debris Flow Initiation Zone. Edge of rubble covered glacier is exposed where material failed. Photo taken by Darryl Lloyd on August 3, 2007.

Figure 80: Southwest face of Mt. Adams before the November, 2006 storm. The old moraine breach was widened and deepened as the Salt Creek Debris Flow occurred. The initiation site is highlighted in red and pointed out by the black arrow. Figure by Darryl Lloyd, photo taken October 13, 2006.

Figure 81: Telephoto of the Salt Creek Debris Flow. The path of the channel is highlighted in red and the area when the flow crossed into the Crofton Creek channel is labeled. Figure by Darryl Llyod, photo taken July 14, 2007.

Figure 82: Map of Trappers Creek Drainage. Black numbers are trail and road indicators, black numbers with white halos refer to GPS points.

Figure 83: Oblique air photo of the upper Trapper's Creek drainage. Black arrows point

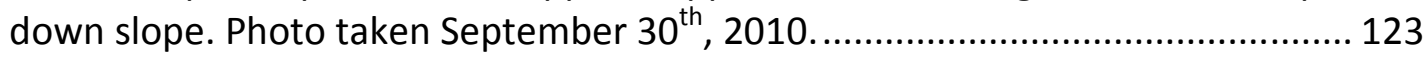

Figure 84: Debris Flow Inventory Map for Mt. Adams............................................... 165

Figure 85: Debris Flow Hazard Map for Mt. Adams produced by logistic regression model. 


\section{Chapter 1: Introduction}

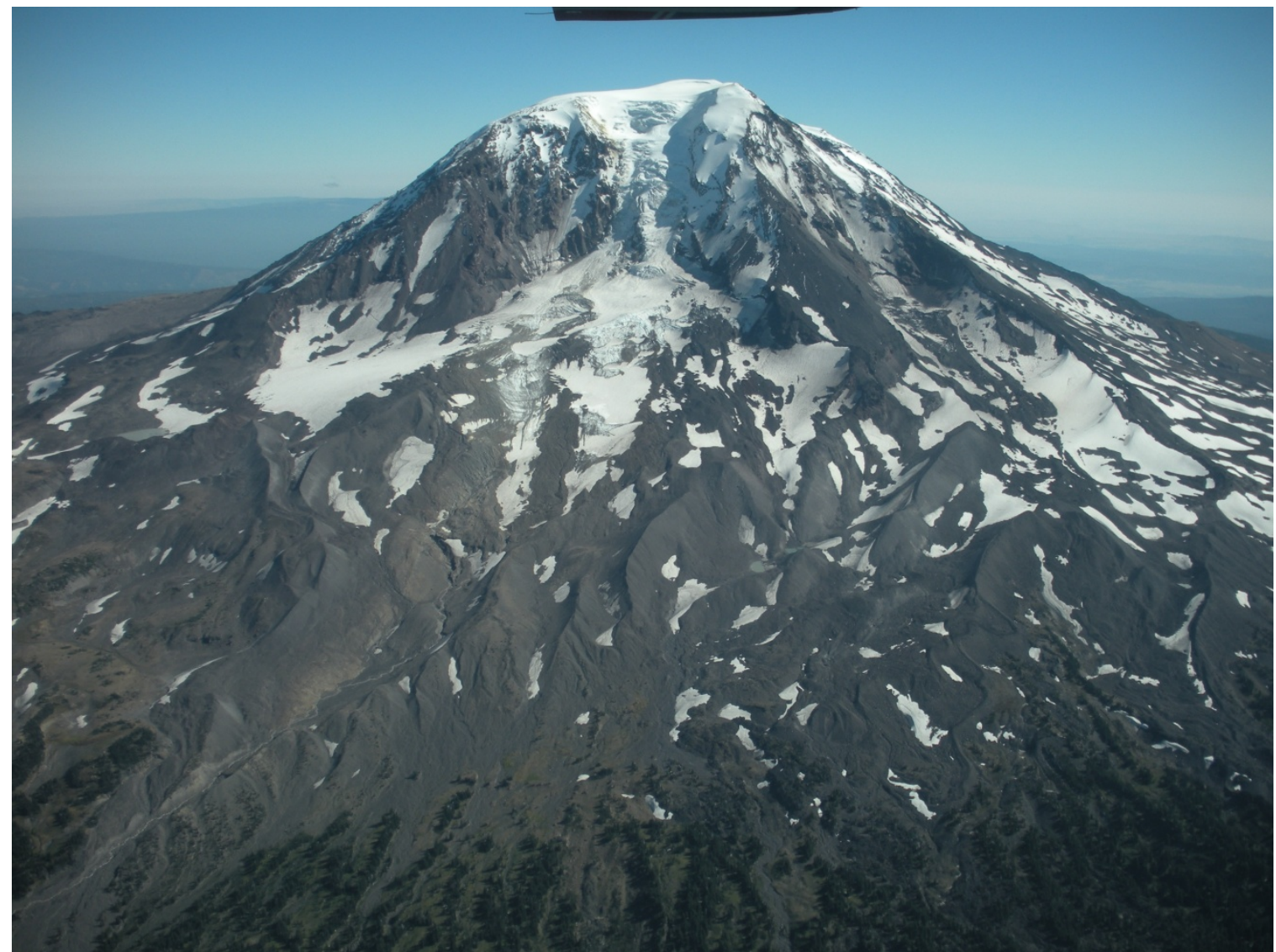

Figure 1: The northwest face of Mt. Adams taken from the air in September of 2010.

Mount Adams (Figure 1) is located in southern Washington state, slightly over

$150 \mathrm{~km}$ to the northeast of Portland, Oregon (Figure 2). It is one of the major volcanoes

of the Cascade Range that stretches across western North America. Like these other

volcanoes it is a stratovolcano with a Quaternary eruptive history. However, Mt. Adams

differs slightly in that it is lies almost directly to the east of another volcano (Mt. St.

Helens) and is located in a remote area. The western half of the mountain is under the

jurisdiction of the Gifford Pinchot National Forest, and the eastern half is a part of the

Yakama Reservation. 


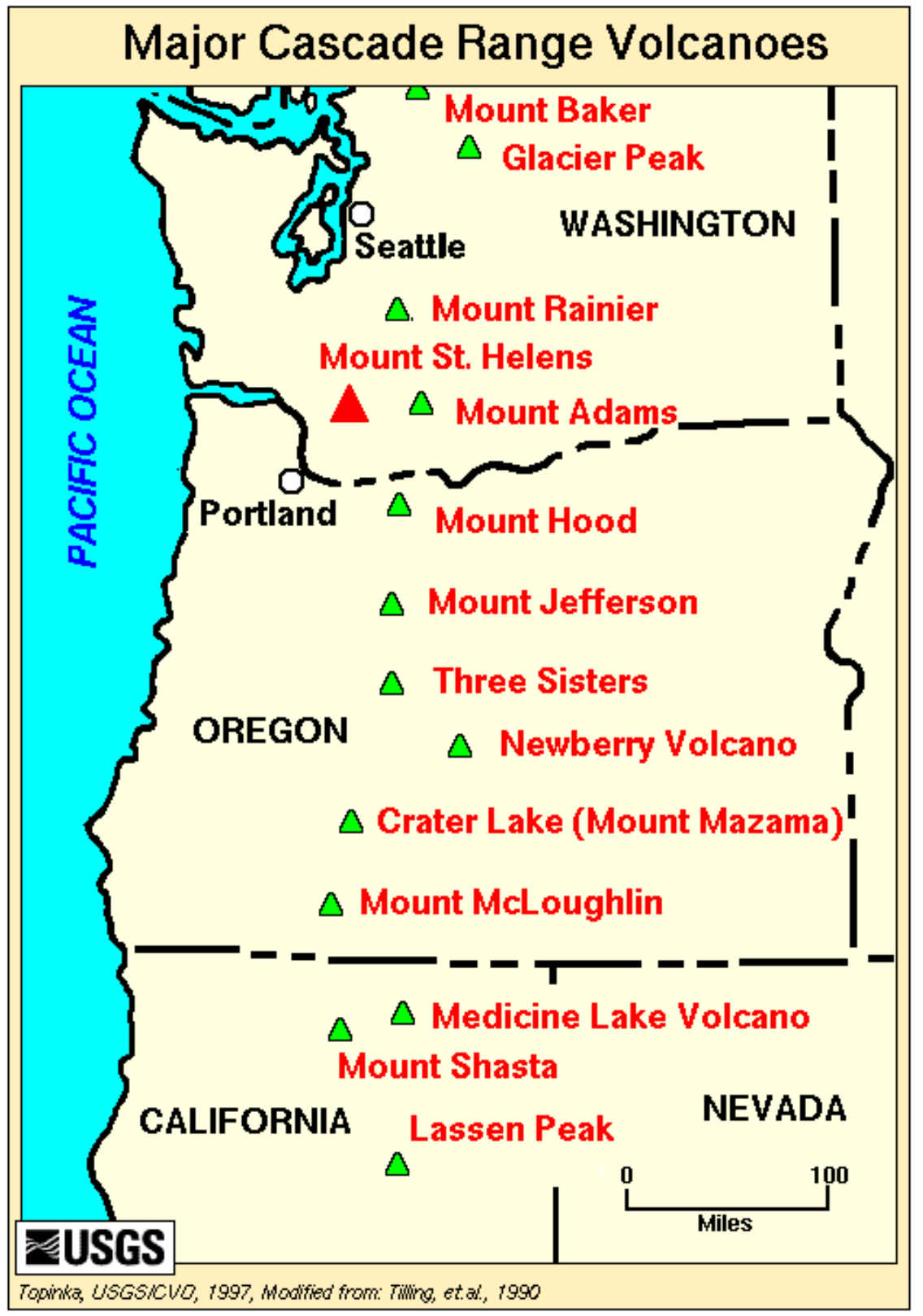

Figure 2: Major Cascade Range volcanoes. Figure from Topinka (1997).

In early November of 2006, a large "Pineapple Express" storm occurred in the

Pacific Northwest causing many debris flows on Cascade volcanoes. This storm caused record rainfall and flooding in many areas. This rain fell before significant snow cover had accumulated on the volcanoes. Many of the debris flows caused by this storm have been investigated. Mt. Jefferson had a debris flow on its western flank (Sobieszczyk et 
al., 2008). Mt. Hood had debris flows in seven of eleven drainages (Pirot, 2010), Mt.

Rainier has experienced twelve debris flows in six drainages between 2001 and 2006

(Copeland, 2009) and at least three large debris flows occurred at Mt. St. Helen's (Olson, 2011). Studying the debris flows that were caused by a single rain event in 2006 across all these mountains will provide comparisons between the mountains and the possibility for a general Cascade volcano debris flow hazard model.

Meteorological and glacial processes frequently cause debris flows at Mt. Adams. These flows generally only affect the areas within a few kilometers of the summit (Hoblitt et al., 1987). Mt. Adams is located in a remote area with little population nearby. Debris flows on Mt. Adams most likely do not pose extreme danger to infrastructure and human life. However, not all Cascade volcanoes are similarly remote. Mt. Adams is unusually secluded due to its location, being half in a wilderness area and half on the Yakama Reservation. The information gained by studying the debris flows of Mt. Adams can be applied to other Cascade volcanoes where debris flows do pose a threat to infrastructure and human life like Mt. Hood in Oregon and Mt. Rainier in Washington.

The purposes of this project are, first, to determine which drainages on Mt. Adams experienced debris flows as a result of the 2006 climatic event and create a detailed map based on the size and distribution of these new debris flows. Second, one needs to determine which conditions or factors, such as glacier presence, vegetative cover, or sediment type, affect debris flow generation. To do this, an inventory of several factors 
in each drainage on the mountain will be compiled to determine if these things differ between drainages that experienced debris flows and drainages with no response. The third goal of the project is to produce a debris flow hazard map of Mt. Adams based on the findings from this study. 


\section{Chapter 2: Background}

\subsection{Volcanic History of Mt. Adams}

The Mt. Adams volcanic field is a part of the Cascade Magmatic Arc, caused by the subduction of the Juan De Fuca Plate beneath the North America Plate off the West Coast of North America (Hildreth \& Fierstein, 1997). The $200 \mathrm{~km}^{3}$ complex andesitic stratovolcano is the second largest, by volume, volcano in the Cascade Range. Sixty vents are exposed in the volcanic field, and another 60 are believed to exist but are covered. About 25 vents are flank vents that erupt magma similar to that erupted centrally. The other vents are peripheral erupters that are believed to have independent conduits based on magma composition and location (Hildreth \& Fierstein, 1997).

The eruptive history of Mt. Adams began about 940 thousand years ago (ka) with major cone building events occurring at 500, 450, and 30 ka (Sherrod \& Smith, 1990). The last major activity of the central cone produced $40-50 \mathrm{~km}^{3}$ of andesite and reconstructed the uppermost $1,300 \mathrm{~m}$ of the modern summit. The present volume of the cone is estimated at $200 \mathrm{~km}^{3}$, however the estimated maximum volume before glacial erosion was $300 \mathrm{~km}^{3}$ (Hildreth \& Lanphere, 1994). Of this volume approximately $85 \%$ erupted from central or proximal flank vents. Compositionally, basalt constitutes 915\%, andesite and basaltic andesite 84-89\%, and dacite 1-2\% (Hildreth \& Lanphere, 1994). In the last 12,000 years, Adams has remained active, experiencing about 24 minor explosive eruptions from both the central cone and flank vents and six lava flows from between 2,100 and 2,600 $\mathrm{m}$ in elevation. The largest of these lava flows occurred 
between 7 and $4 \mathrm{ka}$ and traveled as far as $10 \mathrm{~km}$. The most recent eruption occurred 1,000 years ago and produced a minor tephra layer and possibly a small lava flow on the eastern flank (Hildreth \& Lanphere, 1994).

\subsection{Mt. Adams: Landslides, Lahars, and Debris Flows}

Mt. Adams has a history of landslides and lahars, according to the volcanic hazard assessment of Mt. Adams (Scott et al., 1995):

"Large landslides and lahars that are not necessarily related to volcanic eruptions probably pose the most destructive, far reaching hazard of Mt Adams."

The uppermost portion of Mt. Adams has many areas of weakened rock prone to failure (Scott et al., 1995). If this material gives way, the result would be debris avalanches, which can turn into debris flows. These travel down the mountain's valleys. Areas that are most likely to collapse are the southwest and eastern flanks, due to steeper slopes and deep erosion (Scott et al., 1995). The tributaries of the White Salmon and Klickitat rivers would be areas of discharge for debris flows originating in this area. Debris flows originating on the northwest and northeast sides would discharge in the Lewis, Cispus and West Fork Klickitat river tributaries. Shallower valleys on the north side of the mountain would lessen the magnitude of debris flows as much of the material would be deposited on the flanks of the mountain (Scott et al., 1995).

Over the past 10,000 years, there have been several debris avalanches on the steep upper slopes of Mt. Adams (Scott et al., 1995). At least five lahars and a debris avalanche have moved into the White Salmon River Drainage Basin on Mt. Adams in the 
last 12,000 years. Deposits from these lahars range from 4 to 66 million cubic meters and extend as far as $60 \mathrm{~km}$ down valley (Vallance, 1999).

The largest of the recent lahars occurred roughly six thousand years ago in the White Salmon Drainage (Vallance, 1999). This lahar traveled $60 \mathrm{~km}$ and inundated approximately 15 square $\mathrm{km}$ of the Trout Lake lowland and dammed a stream tributary nearby. Deposits can be found in the lower White Salmon River gorge near the towns of BZ corners and Husum, where deposits are around 2 m thick (Vallance, 1999).

Approximately 200 years ago a debris avalanche on the southwest side of Mt. Adams reached run-up heights of $30 \mathrm{~m}$ but left only a thin veneer on the valley sides and floors. In addition, three smaller debris flows and a debris avalanche traveled between 5 and $15 \mathrm{~km}$ from the mountain (Vallance, 1999).

In 1921 about 4 million cubic meters of rock fell from the head of Avalanche Glacier on the southwest flank. This debris avalanche traveled down the Salt Creek Valley approximately $6 \mathrm{~km}$ and contained enough water to partially transform into small debris flows (Scott et al., 1995).

A debris avalanche occurred on October 20, 1987 below the Klickitat Glacier, on the east side of Mt. Adams. This avalanche travelled $5 \mathrm{~km}$ down the Big Muddy Creek drainage (Darryl Lloyd, personal Communication 2007). 


\subsection{Debris Flows}

\subsubsection{Debris Flow Behavior}

Debris flows are mass movements, constricted in a channelized area, that involve a saturated mix of rock, sediment and organic material (Pierson, 2005). Debris flows can reach very high velocities and can transport boulder sized clasts in suspension causing severe damage to infrastructure and pose a risk to human life (Pierson, 2005). Iverson (1997) distinguishes debris flows by physics, in that both solid and fluid forces influence movement, unlike avalanches which are directed by solid forces or floods which are governed by fluid forces. This definition based on the forces taking place can redefine a plethora of designations, including debris slides, debris torrents, debris floods, mudflows, mudslides, mudspates, hyperconcentrated flows, and lahars to be considered debris flows (Iverson, 1997).

Due to the combination of forces acting in debris flows, they can occur with little warning, similar to solid-force-dominated avalanches, and cause widespread damage traveling long distances, like fluid-force-controlled floods (Iverson, 1997). Many factors influence the behavior of debris flows. They can "bulk up", or increase the mass of the flow due to channel erosion, while they travel down slope (Pierson et al., 1990). "Debulking" can also occur if mixing with excess stream water occurs (Pierson and Scott, 1985).

In the field, it can be difficult to distinguish a debris flow deposit from a flood deposit, but there are some diagnostic attributes to look for. Key features of a debris 
flow deposit include lobate margins, coarse clasts concentrated on the margins, convex surface, flow levees, eroded or splintered trees and stumps with bark only remaining on the downstream side of the trunk, and sandy mud coatings on boulders, logs and stream banks (Pierson, 2005). Flood deposits typically show dunes, ripples, longitudinal bars with a concentration of course clasts on top of them, surfaces cut by scour marks, random placement of cobbles and boulders, debris caught in tree branches, and low density debris at the edge of flow (Pierson, 2005).

\subsubsection{Debris Flow Initiation}

Initiation mechanisms for debris flows are what change the static collection of sediment, soil, rock, and water to a debris flow (Iverson, 1997). Requirements for this event to take place are failure of the mass, enough water to reach saturation and the conversion of energy from potential to kinetic to produce flow like movement (Iverson, 1997). Although separate initiation mechanisms are discussed by many authors (Iverson, 1997; Godt \& Coe, 2007), it is widely agreed that these mechanisms can occur simultaneously or interact with each other making it very difficult to distinguish an exact initiation mechanism. It is also true that field identification of initiation mechanisms is challenging, and diagnostic features of each are not agreed upon.

Slope failures are the predominant debris flow initiation mechanism (Iverson, 1997). In this case, the driving forces overcome the resisting forces as defined by the Coulomb equation. A stable slope has greater resisting forces in the Coulomb equation: 


$$
\tau=(\sigma-\rho) \tan \phi+c
$$

Equation 1

where $\tau$ is the average driving force, $\sigma$ is the normal force, $\rho$ is the pore water pressure, $\phi$ is the bulk friction angle and $c$ is the particle cohesion (Iverson, 1997). Slope failures can be caused by many things: seismic events, volcanic activity, and heavy rainfall. These slope failures manifest in many forms, including landslides, rockfalls or channel sidewall slumping. Not all slope failures initiate debris flows, and many factors contribute to mobility of sediment. Once a slope has failed, resistance to motion is controlled by pore pressure and effective stress (Iverson, 1997).

Excessive flow of water resulting from heavy rain in a dry region can be a debris flow initiation mechanism (Godt and Coe, 2007). Excessive overland flow across unvegetated hillsides can, if there is abundant loose sediment that can be mobilized, form new or widening old rills and gullies; these gullies then coalesce and combine forces forming a debris flow; this process is termed "rilling". If excessive water flows become concentrated in steep bedrock channels, channel scour of sediment causes the conditions necessary for a debris flow to occur. This process was termed the "firehose effect" (Godt and Coe, 2007). Debris flows developed through coalescence of multiple small debris flows within major channels are referred to as "headless debris flows" (Pirot, 2010).

Another debris flow initiation mechanism is what is known as a glacier outburst. This is broadly defined as when a sudden, rapid release of water stored in a basin with 
glaciers occurs. These outburst floods incorporate sediment and transform to debris flows as they move down the mountain (Walder \& Driedger, 1994).

\subsubsection{Debris Flow Producing Basins: Transport Limited or Weathering Limited}

Not all basins that produce debris flows are alike; they can be defined as either transport limited or weathering limited (Bovis \& Jakob, 1999). These definitions can be calculated using a discriminant function based on debris-contributing area, a terrain stability number and drainage density. Transport-limited basins contain unlimited or close to unlimited sediment available for transport via a debris flow. Because these basins always hold a large amount of easily mobilized glacial, colluvial or volcanic materials, they tend to generate a debris flow whenever a climatic threshold is passed. Weathering-limited basins need to have a considerable amount of time to pass before a debris flow can occur because sediment supply is minimal and channel recharge rates are low. In these basins, sediment supply is controlled by the slow process of rock weathering. Dividing debris flow basins into these two groups improves multiple regression results used to predict debris flow attributes (Bovis \& Jakob, 1999).

\subsubsection{Debris Flow Hazard Modeling}

Simple basin morphometric features were combined to make a ruggedness number to predict basins that will produce debris flows (Melton, 1965). Applied uses of Melton's Ruggedness Number (MRN) have shown it to be valuable (Jackson et al., 1987). Others have followed this approach. Willford et al., (2004) looked into many morphometric 
factors of watersheds in order to determine which could differentiate between those that experience the continuum of flooding, debris floods, and debris flows. These processes were identified in the field based on sediment signatures found at the fan of the watershed. Their study determined that MRN combined with watershed length was very accurate in identifying watersheds in British Columbia, Canada prone to flooding, as well as differentiating between watersheds prone to debris flows and debris floods. Flood-prone drainages have a MRN of $<.03$ and lengths averaging $8.9 \mathrm{~km}$, debris floodprone drainages have a MRN of $>.03$ and $<.06$ and lengths averaging $4.4 \mathrm{~km}$, and debris flow-prone drainages have a MRN of $>.06$. and lengths averaging $2.1 \mathrm{~km}$ (Willford et al., 2004).

In order to produce an accurate debris flow volume estimate for a debris flow hazard assessment, channel recharge rates are an important factor (Jakob et al., 2005). Many debris flow hazard assessments provide an accurate volume estimate for the time of investigation, but if that drainage experiences a debris flow or continues to recharge for several years that estimate will become invalid (Jakob et al., 2005).

Determining the hazard level for debris-flow-producing basins has proved to be a challenge, but several attempts have been made using computer and other types of models. LAHARZ is a computer based model that uses a digital elevation model and a given lahar volume to compute the extent of deposit (Iverson et al., 1998). Use of historical records and MRN in a regression model yielded an equation that could predict mean recurrence intervals of debris flows (Coe et al., 2003). 
The method of using multiple regression analysis has been previously used in debris flow associated studies. Bovis \& Jakob, (1999) used a multiple regression to develop prediction equations for debris flows using debris flow peak discharge, average debris flow magnitude, average debris flow frequency and debris flow activity index in southwestern British Columbia. Cannon et al.,(2003 \& 2007) used multiple regression to estimate debris flow volumes using eight morphometric factors in a recently burned area of southern California. These eight factors were basin area, average basin gradient, basin relief ratio, basin ruggedness (MRN), basin area with slopes greater or equal to 30 percent, basin area with slopes greater than or equal to 50 percent, drainage density, and drainage network bifurcation ratio. Fannin and Wise, (2001) used it in the formation of a debris flow travel distance model using predictor variables of reach length, width, and slope angle. Pirot, (2010) used multiple regression to determine important factors in the production of debris flows resulting from the November 2006 storm at Mt. Hood in Oregon. Factors used were rainfall amount, percent bedrock in the upper basin, percent vegetation in the upper basin, percent steep slopes above 33 degrees in the upper basin, gradient of the upper basin, connection to the glacier, glacier area and MRN.

\subsection{Other Cascade Mountain Debris Flow Research}

The severe storm of November, 2006 caused debris flows on several Cascade volcanoes. Mt. Jefferson, located $100 \mathrm{~km}$ east of Salem, Oregon, experienced a debris flow on its western side (Sobieszczyk et al., 2008). This debris flow initiated as a 
snowfield melted due to a combination of high precipitation and warm temperature.

This debris flow bulked up as it traveled down slope eroding previous debris flow, pyroclastic flow, and glacial moraine deposits. The maximum velocity for this flow was calculated at 3.9 meters per second, and the confined flood stage was calculated at 2.4 $\mathrm{m}$. The drainage basins of Milk and Pamelia creeks were the specific locations of this debris flow (Sobieszczyk et al., 2008).

Seven of eleven drainages experienced debris flows on Mt. Hood, located $70 \mathrm{~km}$ east of Portland, Oregon, in early November of 2006 (Pirot, 2010). Landslides initiated 4 of these debris flows while the other three were deemed "headless debris flows" caused by coalescence of minor debris tracks across a hillside into a channel. In this study, each drainage on Mt. Hood was characterized by a list of factors. A logistic regression of these factors determined that the three most important were surface water connection to the glacier, percent vegetation in the upper basin and gradient of the upper basin. Percent vegetation and gradient had an inverse relationship to debris flow occurrence.

On Mt. Rainier, located $70 \mathrm{~km}$ east of Seattle, Washington, twelve debris flows occurred in six drainages between 2001 and 2006 (Copeland, 2009). These debris flows occurred in glacially fed, steep-walled drainages set in unconsolidated Quaternary age material with little or no vegetation. An average elevation of 2,181 m and a slope angle of 39 degrees were measured for the initiation zones. Glacial retreat appeared to be significant in the initiation of debris flows, but no difference in simple glacier metrics 
could be found between glaciers above debris flow heads and those not (Copeland, 2009).

Mt. St. Helens, located $50 \mathrm{~km}$ south of Seattle, Washington, experienced at least three large debris flows and possibly as many as twelve drainages were affected by debris flows in early November of 2006 (Olson, 2011).

\subsection{Madden - Julian Oscillations and the November 2006 Storm}

Heavy precipitation in early November of 2006 fell across the western United States due to a weather disturbance called the Madden-Julian Oscillation (MJO) or more commonly referred to as a "Pineapple Express" storm (Gottschalk et al., 2005). The MJO is a naturally occurring phenomenon that occurs over a ten day period (Figure 3). Seven to ten days before the event, heavy rain falls in the far western Pacific producing a moisture plume that travels northeast coupled with a strong polar jet stream. This creates a strong high pressure area along the northwest coast of North America. Within three to five days before the event, the heavy rain shifts east further extending the moisture plume to the northeast. The polar jet stream splits around the high pressure zone as it weakens and shifts westward. Next, the precipitation event takes place as the heavy rain weakens and continues to shift, and the moisture plume extends over the Hawaiian Islands and across the ocean hitting the West Coast of North America. The jet stream becomes strong below the high pressure area driving the heavy rain onto land (Gottschalk et al., 2005). 


\section{Typical Wintertime Weather Anomalies Preceeding Heavy West Coast Precipitation Events}

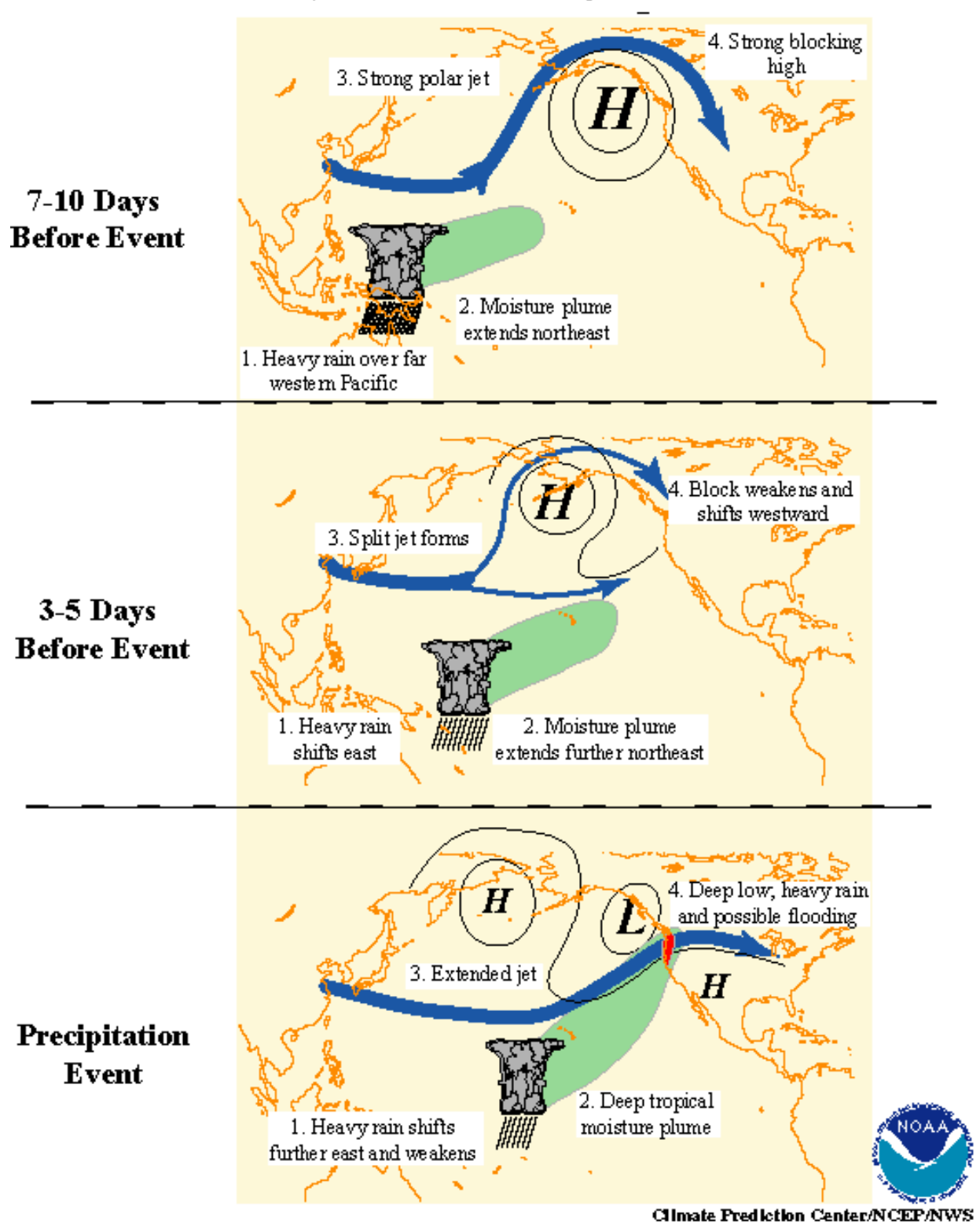

Figure 3: Madden - Julian Oscillation weather pattern before heavy precipitation occurs. (Figure from Gottschalk et al., 2005). 
The MJO tends to be active during the El Niño Southern Oscillation (ENSO)

neutral and weak ENSO winters. El Niño occurs when unusually warm ocean temperatures occur in the Equatorial Pacific, as opposed to the La Niña, which is characterized by unusually cold temperatures (Gottschalk et al., 2005).

In Washington State, during November of 2006, the MJO caused twelve rivers to reach all time flood high records, eleven counties experienced major floods, and Seattle, Hoquiam and Olympia broke monthly precipitation total records (Bond, 2006).

\subsection{Damages in the Gifford Pinchot National Forest}

The Gifford Pinchot National Forest estimated that more than $\$ 17$ million in damages were the result of the storms and floods of 2006 (USDA Forest Service, 2007). Campgrounds, trails and roads were affected and remained closed for months and in some cases years while cleanup crews slowly made their way around the forest. As of March 29, 2007, closures around Mt. Adams included Forest Road 23 due to a washout .8 miles north of the Junction with Forest Road 90, in the lower portion of the Lewis Creek drainage. Below the Killen Creek and Muddy Fork drainages, Route 21 at milepost 3.5 and Route 56, at an unspecified location, also underwent repairs (USDA Forest Service, 2007).

\subsection{Storm Rainfall Data}

Mt. Adams is fairly remote, and is a significant distance from the two closest Doppler Weather Stations located in Portland, Oregon and Pendleton, Oregon. Because 
of this, spatial storm data was only available above $10,000 \mathrm{ft}$, which is higher than the areas of significance to this study. In addition, full coverage of the mountain is also not available, making comparing the data across the drainages impossible.

However, even though storm total data could not be measured spatially for the November, 2006 storm, SNOTEL sites located close to the mountain give us an idea of the rainfall pattern. SNOTEL sites are run by the National Resources Conservation Service of the United States Department of Agriculture, and they operate a variety of climate sensors including accumulated precipitation. Three sites are located close to Mount Adams. Station 804 is located at Surprise Lakes and is to the southwest of the summit at an elevation of $1,300 \mathrm{~m}$, station 702 at Potato Hill is located due north of the mountain at an elevation of 1,370 m, and station 599 at Lost Horse is located to the northeast at an elevation of 1,560 m. Station 599 is significantly farther away from Mt. Adams than the other two. These three stations show a pattern of more rain falling in the southwest than in the north and east. Station 804 recorded a high of $17.2 \mathrm{~cm}$ of rainfall for November $7^{\text {th }}, 2006$ while stations 702 and 599 recorded highs of 9.9 and 6.1 $\mathrm{cm}$ respectively on the same day. Station 804 showed an accumulation of $71.6 \mathrm{~cm}$ of rainfall from November $1^{\text {st }}-15^{\text {th }}, 2006$ while stations 702 and 599 recorded 46.5 and $21.3 \mathrm{~cm}$ respectively. See Appendix for a full SNOTEL data table. 


\section{Chapter 3: Methods}

\subsection{Field Methods}

Field surveying was completed during the summers of 2009 and 2010. Drainages were surveyed by hiking the "Round the Mountain" or Trail 9 (which overlaps the Pacific Crest Trail) to determine occurrence of debris flows. Upper drainage basins were later visited several at a time by hiking up one drainage across the upper basins and then down a different basin. Due to such a large study area, not every drainage was visited on foot. Areas not visited include Trappers Creek, Little Muddy Creek, Rusk Creek and Big Muddy Creek. Darryl Lloyd did field work to obtain data and photos that are included in this project. This field work was conducted in 2007 by hiking the large areas in the Rusk Creek, Big Muddy Creek, Salt Creek, Crofton Creek and Adams Creek drainages.

Equipment used in this project was a Garmin eTrex Venture HC GPS unit to track location. In addition, a NIKON COOLPIX S560 and a Canon PowerShot A610 camera were used to document the landscape.

Soil sampling was done during the summer of 2010 in many locations for later grain size analysis and bulk density calculations (Figure 4). In drainages that experienced debris flows, samples were taken from the initiation zone or if access was not possible, from material next to and indicative of initiation zone material. For drainages that did not experience debris flows, samples were taken from similar elevations that debris flows had initiated in other drainages. Samples were taken using a small trowel and a $375 \mathrm{ml}$ measuring cup. Three samples were taken from each site with an approximate 
volume of $375 \mathrm{ml}$ each. Volume of the hole for bulk density was measured by lining the hole with plastic and then pouring water into the plastic until full and then measuring the volume of that water (Pirot, 2010). Samples were stored in labeled plastic bags. The locations of samples were marked using a GPS.

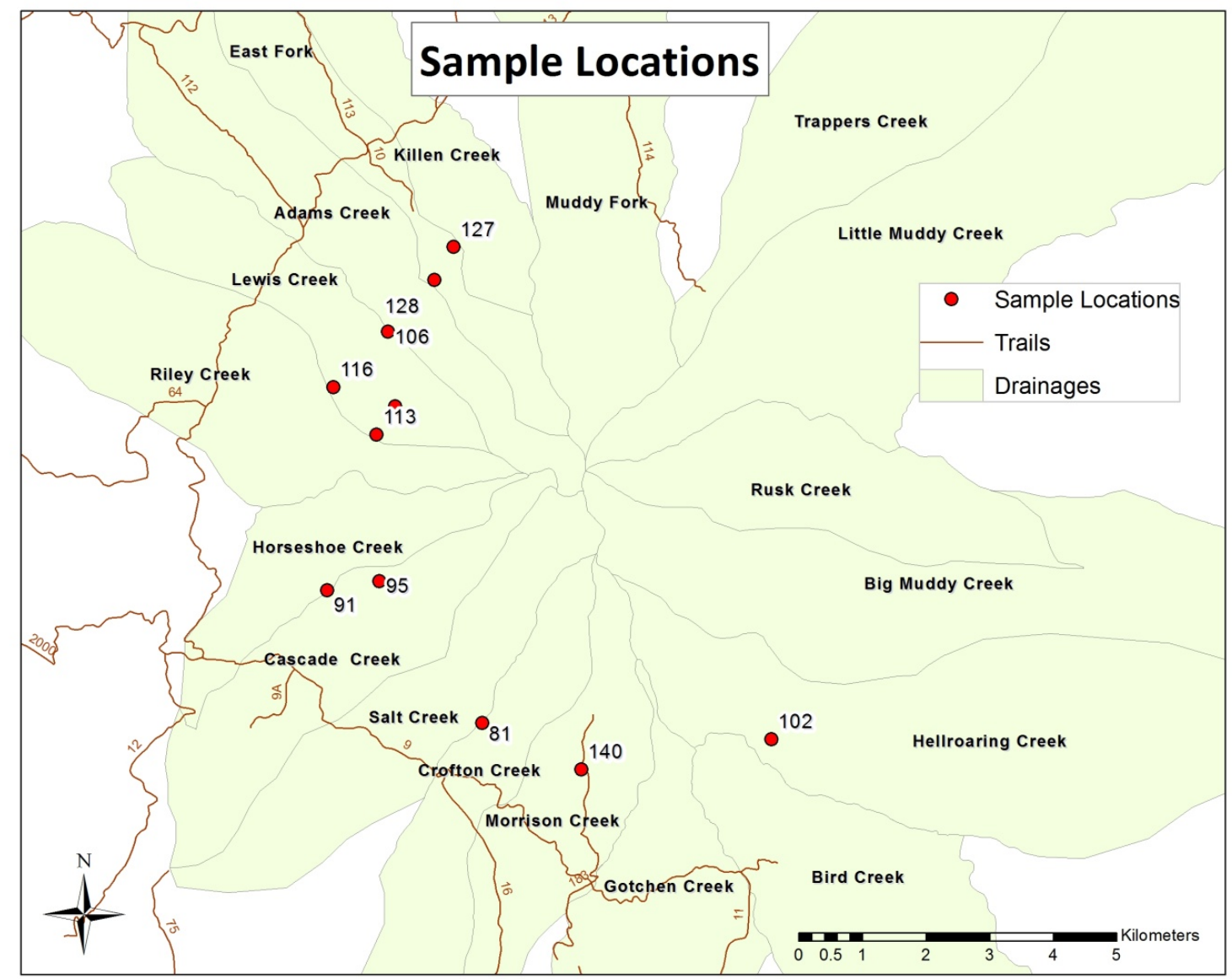

Figure 4: Soil sample locations.

\subsection{Lab Methods}

In the lab, the samples collected in the field were put through a sieve analysis (ASTM, 1990). The samples were dried and weighed and then put through a stack of sieves. The stack included sieve numbers 10, 30, 60, 100, 200 and 230. Dry sieving 
resulted in less than $5 \%$ fines and so hydrometer analyses were not necessary. Sieves were shaken for ten minutes and then the amount of the sample retained on each sieve was weighed. Grains were classified according to Table 1.

Table 1: Particle size distribution and classification of soil samples

\begin{tabular}{|l|l|l|}
\hline Sieve \# & Size $(\mathrm{mm})$ & \\
\hline 10 & $>2$ & Gravel \\
\hline 30,60 & $.25-2$ & Sand - Coarse \\
\hline 100 & $.149-.25$ & Sand - Medium \\
\hline 200 & $.063-.149$ & Sand - Fine \\
\hline 230 & $<.063$ & Silt \& Clay \\
\hline
\end{tabular}

\subsection{Oblique Air Photo Methods}

\subsubsection{Orthophoto Analysis}

In order to determine what year drainages experienced debris flows,

orthophotos from before and after the 2006 storm were examined. Orthophotos were obtained from the National Agricultural Imagery Program (NAIP). These images are scanned photographs acquired with a precision aerial mapping camera at a nominal scale of 1:40,000 on color positive film (NAIP, $2006 \&$ 2009). The 2006 photo is compiled of images taken during July of 2006 and was published in March of 2007. The 2009 photo is the next available photo taken since the November 2006 storm. The 2009 photo was taken during July of 2009 and was published in March of 2010 (NAIP, 2006 \& 2009).

Orthophotos are orthorectified so they can be used in a geographic information system. Each drainage was examined by switching back and forth between the 2006 and 2009 photos at a scale up to 1:6,000 to look for differences. In drainages visited in the 
field the presence of a debris flow was confirmed and then dated based on differences found or not found in the orthophotos. If significant differences could be found in the two photos then the debris flow was determined to be a result of the 2006 storm. Differences were usually found in the lower drainage where a new deposit could be identified or in the upper drainage where a new landslide scarp could be found or new coalescence of deep incised channels. If no differences were found in the photos, then the debris flows were determined to have occurred before the 2006 storm.

\subsubsection{Oblique Air Photo Analysis}

For additional coverage of the mountain, and to gain knowledge about areas not visited in the field, I took photos from a small plane that flew around Mt. Adams twice in a clockwise direction between 3 and $5 \mathrm{pm}$ on September $30^{\text {th }}, 2010$. The photos were taken of the upper drainage basins on Mt. Adams. Many of these photos are included in the results section of this thesis. These photos were taken on two digital cameras, a NIKON COOLPIX S560 and a Canon PowerShot A610.

Identifiable landmarks were found in the oblique air photos in order to determine which drainages were represented in each photo. These landmarks were objects like glaciers, ridges, lakes and geologic deposits. When the basin represented was identified, things like deposits, scarps and coalescence of deep incised channels were looked for to confirm debris flow action in drainages visited in the field or to find debris flows not visited in the field. 


\subsection{GIS Evaluation of Basin Attributes}

ArcMap 9.3, student edition and ArcMap 10 were used as the geographic information systems for this study. Elevation data are presented in a Digital Elevation Model (DEM) from the National Elevation Dataset which has a resolution of one-third arc-second, or about 10 meters, which is the best available for the study area. LiDAR is not available for the study area.

A list of 16 drainage attributes was compiled by Pirot (2010) to characterize drainages on Mt. Hood in order to determine which attributes might contribute to debris flow initiation. Of the 16 attributes used by Pirot (2010), 12 were also used for this thesis. The factors, and how they were measured or calculated, are listed below.

1. Elevation of Initiation Zone was measured for those drainages that experienced debris flows using the identify tool in ArcMap at the location of the imitation zone on the DEM. Initiation zones were identified in the field or by comparing before and after orthophotos (Pirot, 2010).

2. Total Basin Area was calculated in ArcMap. Basins were designated by creating polygons in ArcMap. Hydrologic unit boundaries, subwatershed or $6^{\text {th }}$ level, from the U.S. Department of Agriculture, Natural Resources Conservation Service were used as an outline for creating the drainage basins. Since the given basins sometimes had several draining streams, they were divided based on geographical boundaries seen using the DEM and $6 \mathrm{~m}$ contours. The method used was to follow ridges from the top of the mountain and then pinch together 
at the first point where a stream entered another stream that was drained by an area not already included in the basin (Modified from Pirot, 2010).

3. Upper Basin Area was calculated the same way as the total basin area. The upper basin was designated by including the top of the basin and then pinching together at the first natural constriction of the basin (Pirot, 2010).

4. Distance From the Glacier was calculated using the measure tool in ArcMap, and is the distance from the glacier to the beginning of the stream (Modified from Pirot, 2010).

5. Glacier Area was calculated using ArcMap. The glacier data are from the U.S. Glacier Database (http://www.glaciers.pdx.edu), which is a 1:100,000 scale digital map with data from 2005. It was clipped to the outline of the upper drainage basin polygon, and then the area was calculated in square meters using the calculate geometry tool (Modified from Pirot, 2010).

6. The Geology of the Upper Basin was determined from the digital 1:100,000-scale geology of Washington State, version 1.0, by Washington Division of Geology and Earth Resources Staff (2005) geologic map. This geology layer was clipped to the upper basin polygon, and the area of each unit was calculated in square meters. These areas were then turned into percent of the upper basin by dividing by the total area of the upper basin (Pirot, 2010).

7. Direct Connection to the Glacier. If the stream began directly at the edge of the glacier, then it was considered directly connected to the glacier. If the stream 
began in an un-glaciated area, then the basin was considered to not be directly connected to the glacier (Modified from Pirot, 2010).

8. The Total Basin Height was determined by subtracting the lowest basin elevation from the highest elevation of the basin (Pirot, 2010). Measurement descriptions for the highest and lowest basin elevations are in factor numbers 18 and 19.

9. The Gradient of the Upper Basin was calculated by dividing the upper basin height by the upper basin length (Modified from Pirot, 2010).

10. The Percent Vegetation in the upper basin was determined from existing vegetation digital map (US Forest Service, 2008) and by air and orthophoto analysis. Polygons were created in ArcMap outlining areas of vegetation. The area of these polygons was calculated and then divided by the total upper basin area to determine percent vegetation (Modified from Pirot, 2010).

11. The Percent Steep Slopes were determined in ArcMap. Areas that are 33 percent steep or steeper are considered to be steep slopes (Pirot, 2010). The DEM was clipped to the upper basin polygon and then the spatial analyst extension was used to make a slope map. The visuals of the slope map were changed so that slopes above 33 degrees were another color. The areas above 33 degrees were then outlined with polygons, and their areas were calculated. Percentages were determined by dividing the areas of steep slopes of the total upper basin area (Modified from Pirot, 2010).

12. Melton's Ruggedness Number (MRN) was calculated by Melton's Equation, 


$$
M R N=\frac{H_{T}}{\sqrt{A_{T}}}
$$

where $\mathrm{H}_{T}=$ Total Basin Height and $\mathrm{A}_{T}=$ Total Basin Area (Pirot, 2010; Melton, 1965).

The four factors from Pirot (2010) that were not used were: 1) area above the initiation zone, because it only applied to drainages with debris flows, 2) storm rainfall amount, because of the distance of Mt. Adams from Doppler radar stations, 3) azimuth, because it is a geographic feature that affects vegetation and rainfall amounts (Pirot, 2010) which are measured elsewhere in the study, and 4) percent bedrock in the upper basin because it is represented in the geology of the upper basin.

In addition to the twelve factors taken from Pirot, 2010, I added eight additional factors that may influence debris flow initiation.

13. Glacier Retreat was measured from 1904 to 2006 from data that used a combination of aerial photos, oblique photos and orthophotos (Sitts et al., 2010). Data were given for each glacier. Because some drainages contain more than one glacier in their upper basins, and because some glaciers span several drainages, each drainage was given a value of average change in area or percent of all the glaciers present within its boundaries or above it. This causes some drainages to have glacial retreat values even though they have a zero value for glacial area. An example of this is Bird Creek. There are no glaciers within the boundaries of the drainage, but the drainage is below the Gotchen Glacier so the 
retreat values are representative of the retreat of Gotchen Glacier. Three sets of data were used for this thesis, total area loss from 1904 to 2006, percent area loss between 1904 and 2006, and area lost between 1998 and 2006. Some drainages that were determined to have zero glacial area will still have values for glacial retreat. This is because glacial area was calculated from electronic data clipped to the polygon of the drainage. The glacial retreat data are not spatial and are only given as values per glacier, because of this, the values are an average of glacial above each drainage. An example is the Bird Creek Drainage, which doesn't have a glacier within its boundaries but is still below the Gotchen Glacier.

14. The Upper Basin Length was calculated using the measure tool in ArcMap and was measured from the top of the basin to the bottom, following the path of the drainage stream.

15. Grain Size Percentages were determined from the grain size analysis in the lab.

16. Average Annual Precipitation was calculated from data from the PRISM group at Oregon State University (http://www.prismclimate.org). Data used were contours of equal annual mean precipitation. The contour data were clipped to the polygon of the upper basin and then the areas of each contour were calculated. The average annual precipitation was calculated by first multiplying each range by the area of the upper basin covered by that value. These values were then summed and divided by the total area of the upper basin to yield 
average annual precipitation for the entire drainage. This is explained in the equation below, where $P$ is average annual rainfall of the entire upper basin, $R_{n}$ is the average annual precipitation of the nth contour, $A_{n}$ is the area covered by the nth contour in the upper basin, and $A_{T}$ is the total area of the upper basin. Data were given in inches of rainfall but were converted to meters.

$$
\mathrm{P}=\frac{\left(\sum_{1}^{n} \mathrm{R}_{\mathrm{n}} * \mathrm{~A}_{\mathrm{n}}\right)}{A_{T}}
$$

17. The Upper Basin Height was determined by subtracting the lowest elevation of the upper basin from the highest elevation of the upper basin.

18. Highest Elevation of the Basin was determined in ArcMap using the DEM. The DEM was clipped to the outline of the upper basin polygon, and the highest value within that clip was used as the highest elevation of the basin.

19. The Lowest Basin Elevation was determined the same way as the highest elevation. The DEM was clipped to the polygon of the lower basin, and the lowest value of that clip was used as the lowest basin elevation.

20. The Lowest Elevation of the Upper Basin was determined the same way as the highest elevation of the basin and the lowest elevation of the basin. The DEM was clipped to the upper basin polygon, and the lowest elevation of that clip was used as the lowest elevation of the upper basin. 


\section{Chapter 4: Results}

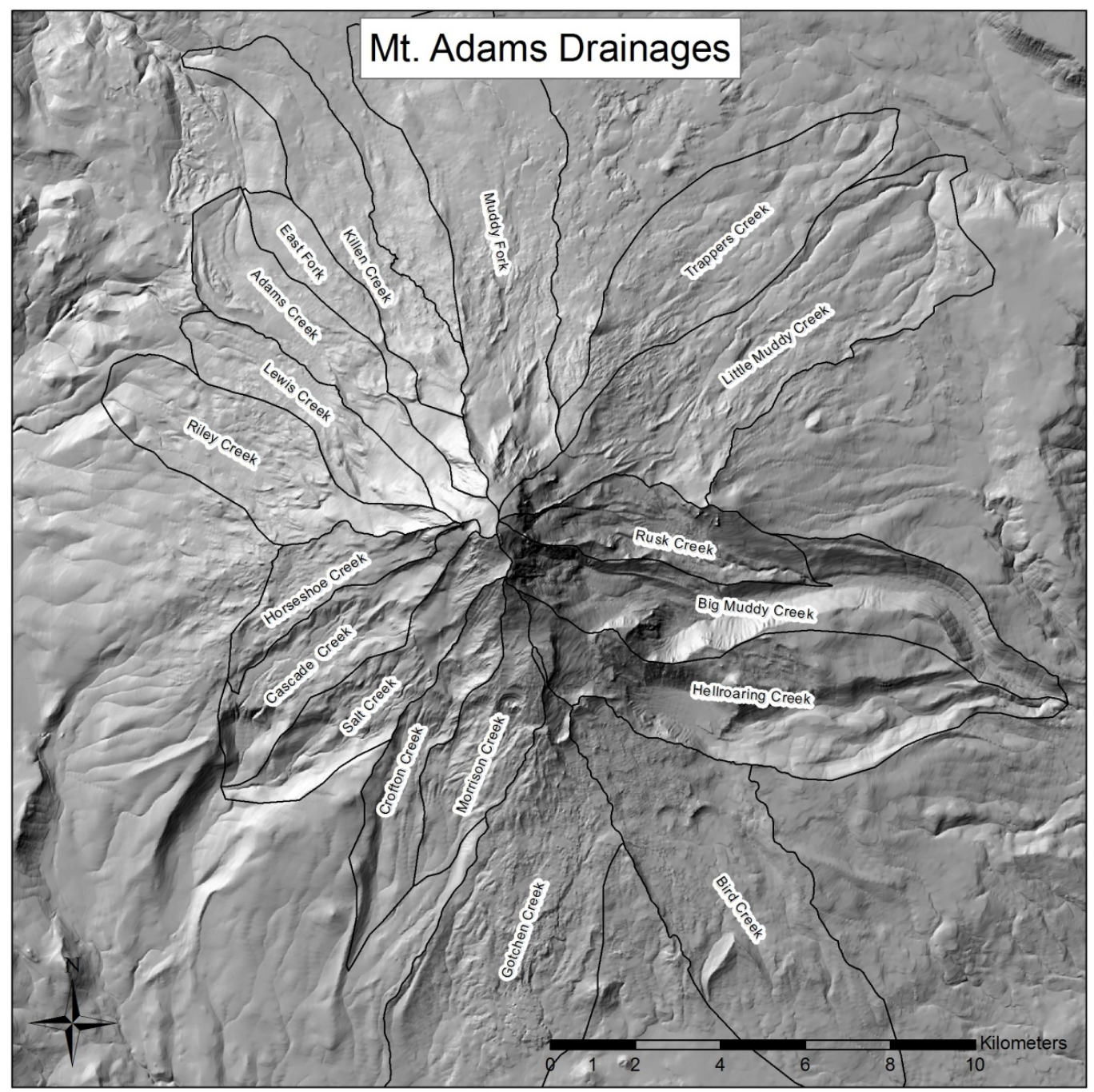

Figure 5: Location map of drainages on Mt. Adams displayed over the $10 \mathrm{~m}$ DEM.

\subsection{Introduction to Results}

Following the methods described in Chapter 3, eighteen drainages are defined at Mt. Adams (Figure 5). The following sections will describe each drainage, in alphabetical order, and evidence will given to support the occurrence or lack of occurrence of 2006 or older debris flows. Four drainages experienced debris flows as a result of the November, 2006 storm. An additional three drainages have experienced debris flows 
between 2006 and 2009. Because no other large climatic event occurred between 2006 and 2009, and no reports of damage were found between 2006 and 2009, it is most likely these three debris flows were also the result of the November 2006. Four drainages showed evidence of past debris flow activity, but orthophotos taken before and after the storm indicate this activity occurred before the 2006 storm. The seven remaining basins did not have evidence of recent debris flow activity.

\subsection{Basins}

\subsubsection{Adams Creek}

Adams Creek is located in the northwest quadrant of Mt. Adams (Figure 6). In 2006 this drainage experienced a debris flow that traveled approximately $3,900 \mathrm{~m}$. This debris flow was caused by collapse of over-steepened and saturated moraine material (Darryl Lloyd, Personal Communication 2007). This debris flow created a deposit approximately $300 \mathrm{~m}$ wide, $900 \mathrm{~m}$ long and several meters thick at an elevation of 1,830 m (Figures 7 \& 8). After initiation, the debris flow travelled through a tapered gap, referred to as "The Narrows," caused by two moraines (Figure 9), and spilled out onto a plain. (Darryl Lloyd, Personal Communication 2007).

Reconnaissance

Initial reconnaissance was conducted in the summer of 2009. At the location of Trail 9, a wide boulder deposit (Figures $7 \& 8$ ) was encountered with many down trees interspersed in the rubble. Looking upstream several landslide scarps that appeared 
relatively fresh were visible in the sidewalls of the channel. Vegetation was sparse to non-existent in the channel or deposit areas.

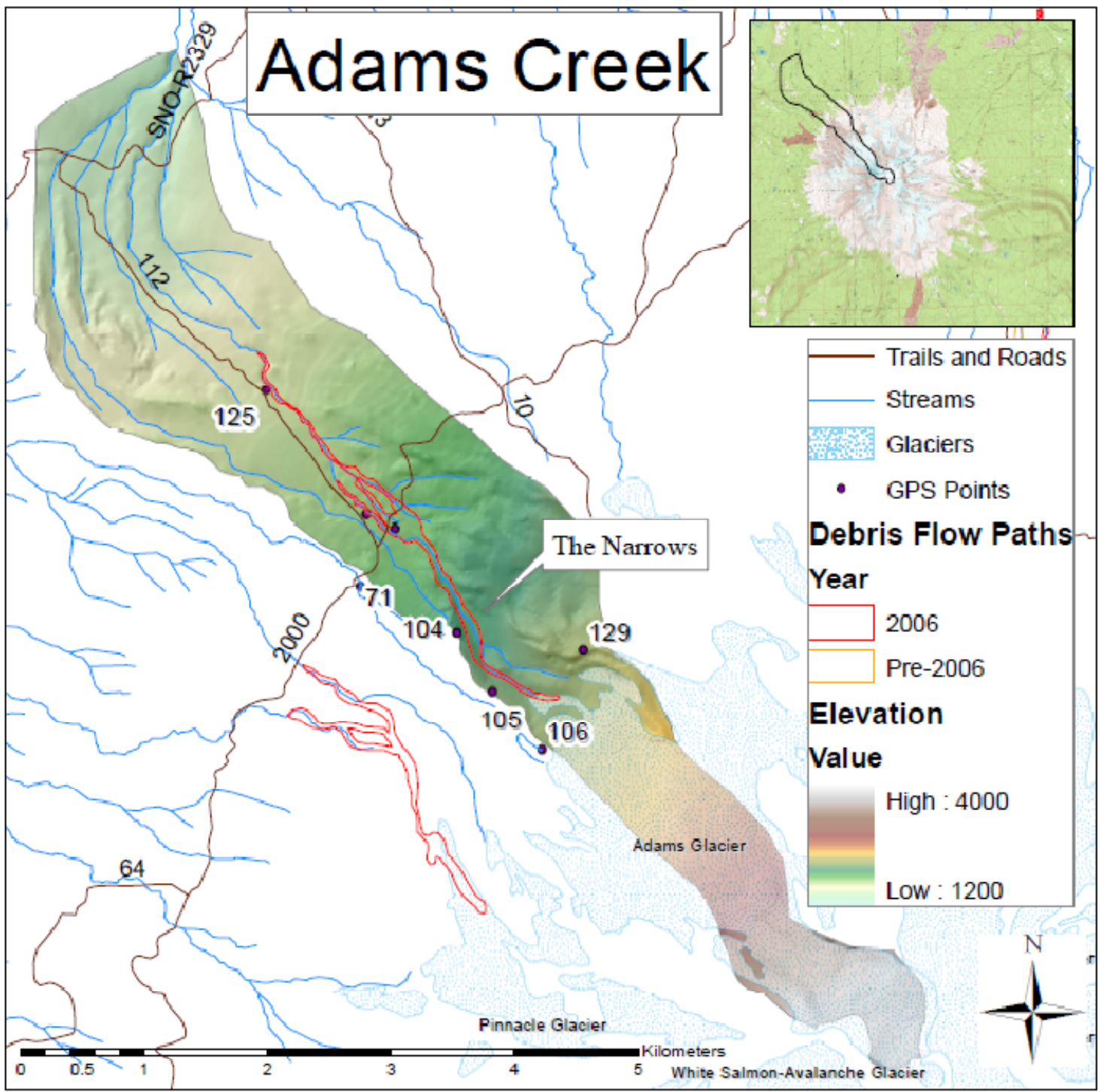

Figure 6: Map of Adams Creek Drainage. Black numbers are trail and road indicators, black numbers with white halos refer to GPS points. Callout label points to the area referred to as 'The Narrows'.

Initiation Zone

During the summer of 2010 the upper Adams Creek drainage was explored by hiking a ridge between the Adams and Lewis Creek drainages. Landslides on the channel 
walls were visible in several places (Figure10), and the debris flow action appeared visible all the way up to the contact with Adams Glacier, where more relatively fresh landslide scarps are observed (Figure 11). All of these scarps were in the channel, and were most likely caused by increased flow in the stream undercutting the base of the channel sidewalls. It is difficult to know which landslide scarp could be the initiation zone, however, it is clear that this debris flow was initiated by heavy water flow and an in-channel landslide.

\section{Sample Collection}

Three soil samples for Adams Creek were taken from GPS point 106. This location was not on the scarp due to hazardous terrain, but the material was geologically mapped the same as the initiation zone and visibly similar. This area was mapped as Quaternary Glacial Drift (Qad) (Department of Natural Resources, 2005).

Sieve Results

Samples from Adams Creek drainage are presented in Table 2 along with average values. Bulk density was measured at $1.7 \mathrm{~g} / \mathrm{cm}^{3}$, and the sample contained $27 \%$ gravel, $71 \%$ sand and $3 \%$ fines.

Table 2: Adams Creek sieve results, Sample 106 subsets 1, 2 and 3. See Table 1 for exact size definitions. Bottom row holds the average values.

\begin{tabular}{|c|c|c|c|c|c|c|c|}
\hline \multirow{2}{*}{$\#$} & \multirow{2}{*}{$\begin{array}{c}\text { Bulk Density } \\
\left(\mathrm{g} / \mathrm{cm}^{3}\right)\end{array}$} & Gravel & Sand & \multicolumn{3}{|c|}{ Sand Distribution } & \multirow{2}{*}{$\begin{array}{c}\text { Silt \& } \\
\text { Clay }\end{array}$} \\
\cline { 5 - 8 } & 1.7 & 27 & 72 & 50 & 11 & 11 & 2.5 \\
\hline 1 & 1.8 & 35 & 62 & 44 & 10 & 7 & 2.6 \\
2 & 1.6 & 19 & 79 & 64 & 9 & 6 & 3.7 \\
\hline $\bar{x}$ & $1.7 \pm .1$ & $27 \pm 7.9$ & $71 \pm 8.8$ & $53 \pm 10$ & $10 \pm .8$ & $8 \pm 2.3$ & $2.9 \pm .7$ \\
\hline
\end{tabular}




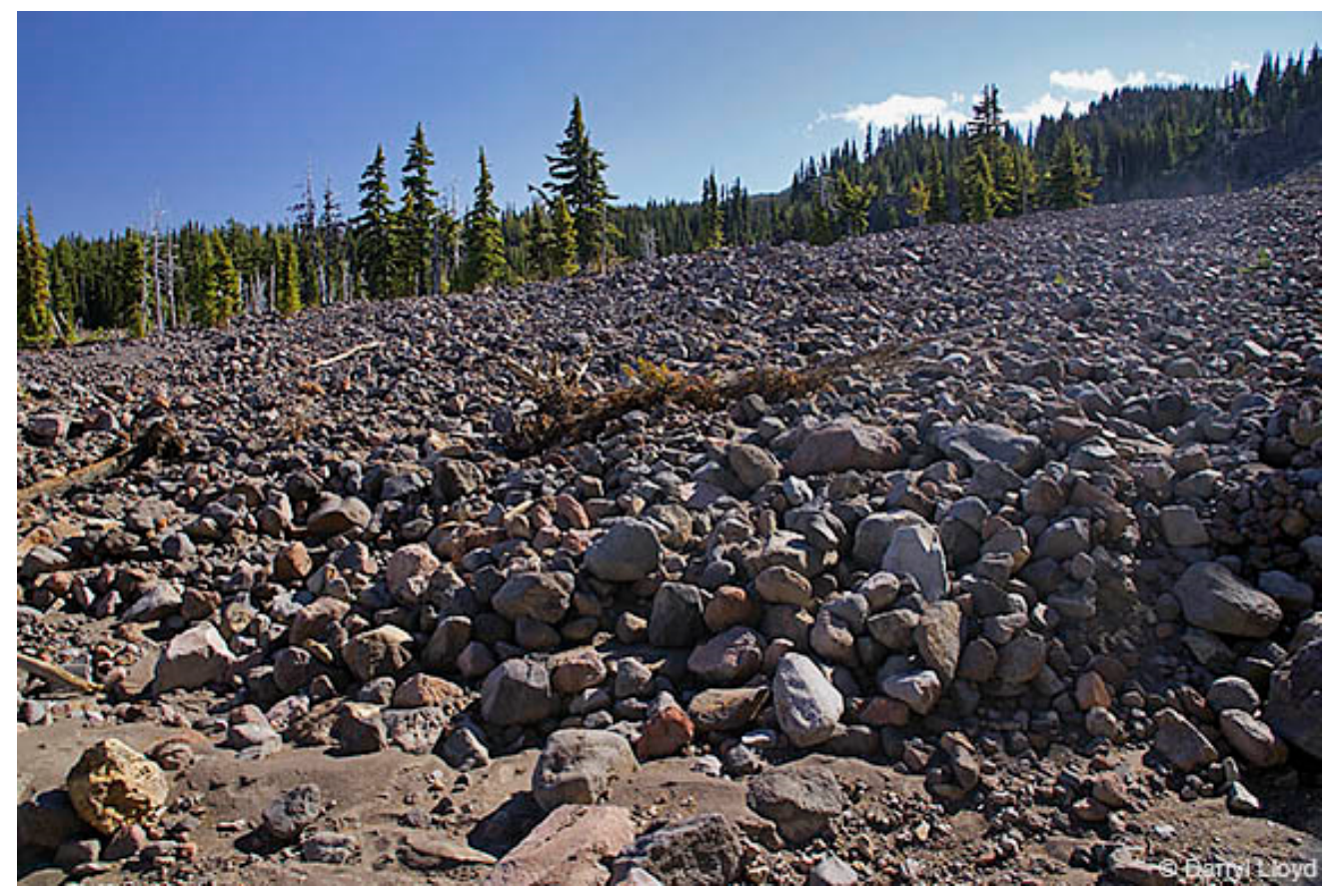

Figure 7: Adams Creek debris flow deposit from the Pacific Crest Trail looking northeast. Photo taken by Darryl Lloyd on August 17, 2007.

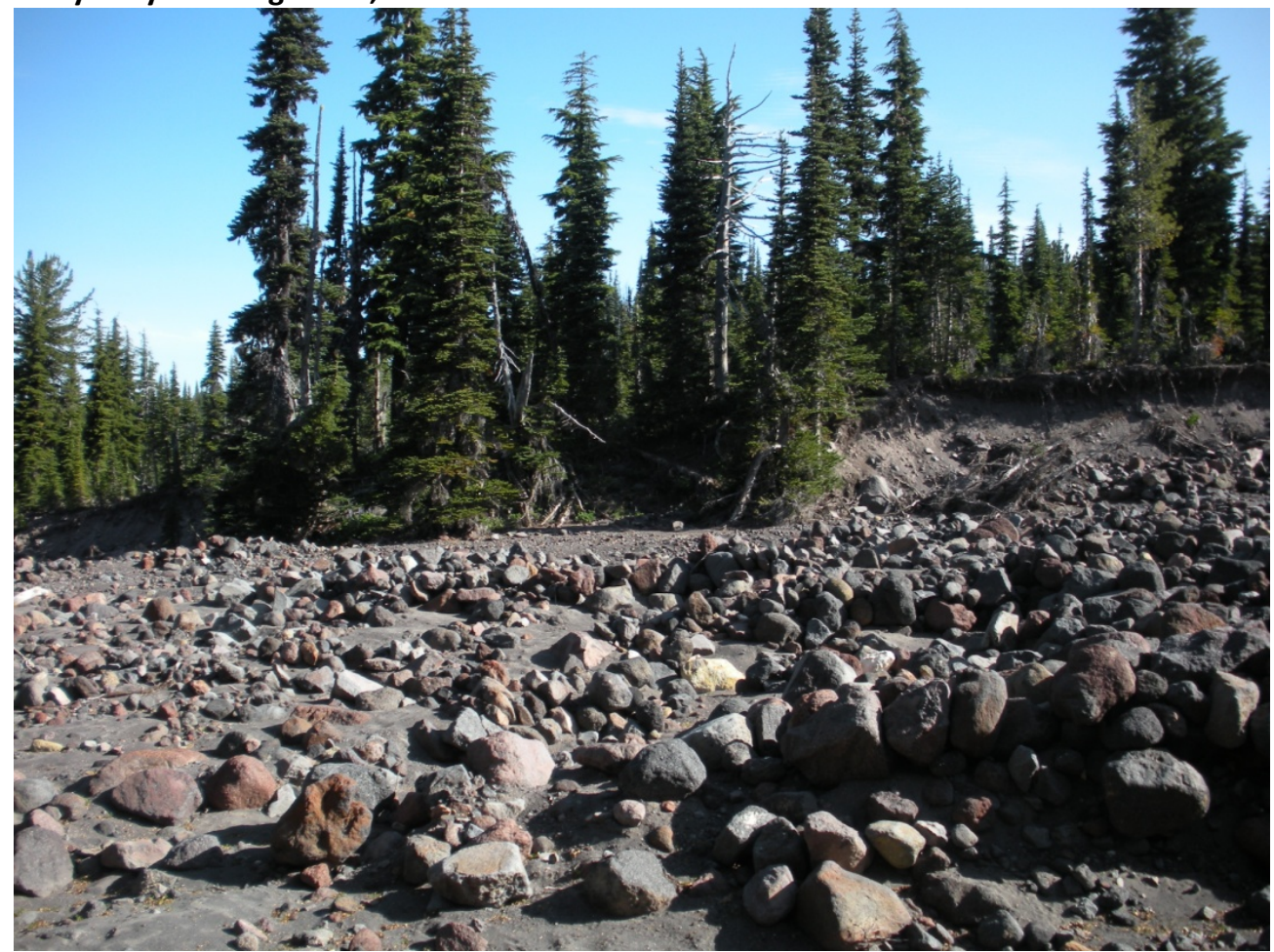

Figure 8: Sandy mud coated boulder deposit in the Adams Creek Drainage. Photo taken from GPS point 125 in the summer of 2010. 


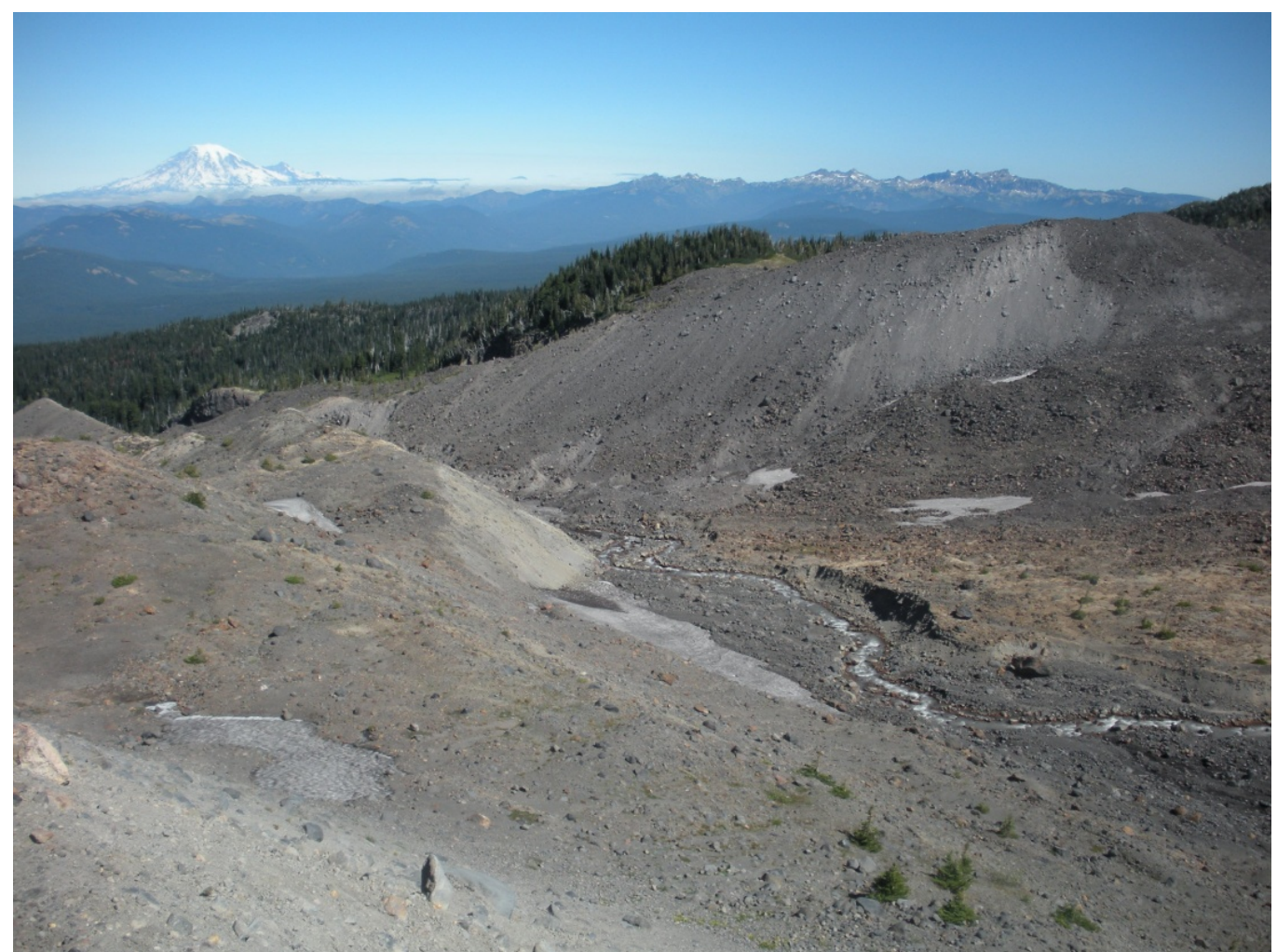

Figure 9: "The Narrows" of Adams Creek Drainage looking northwest with Mt. Rainier in the background. Photo taken from GPS Point 104 in the summer of 2010.

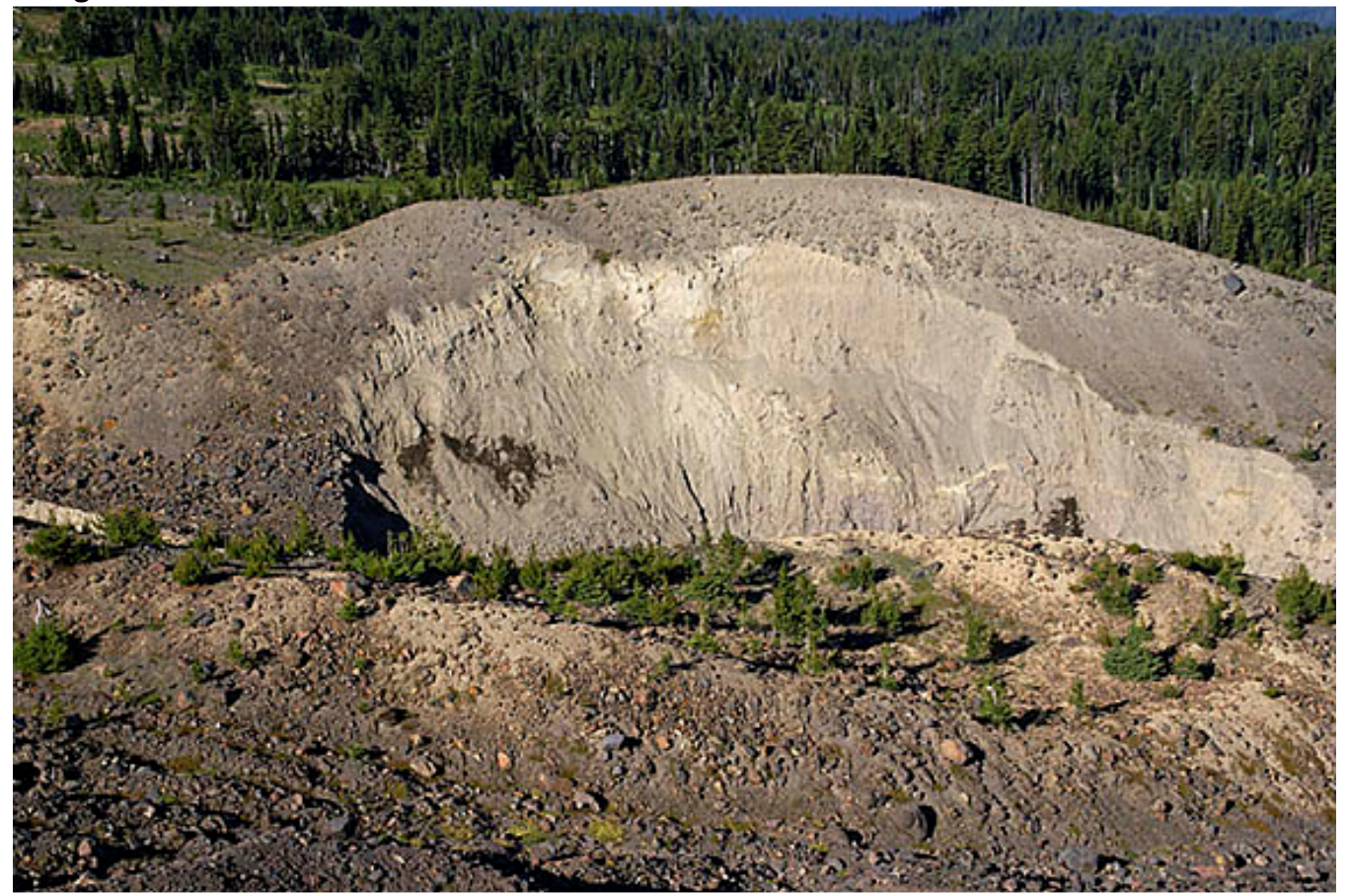

Figure 10: Collapsed moraine in the upper Adams Creek Drainage. Photo taken by Darryl Lloyd in 2007. 


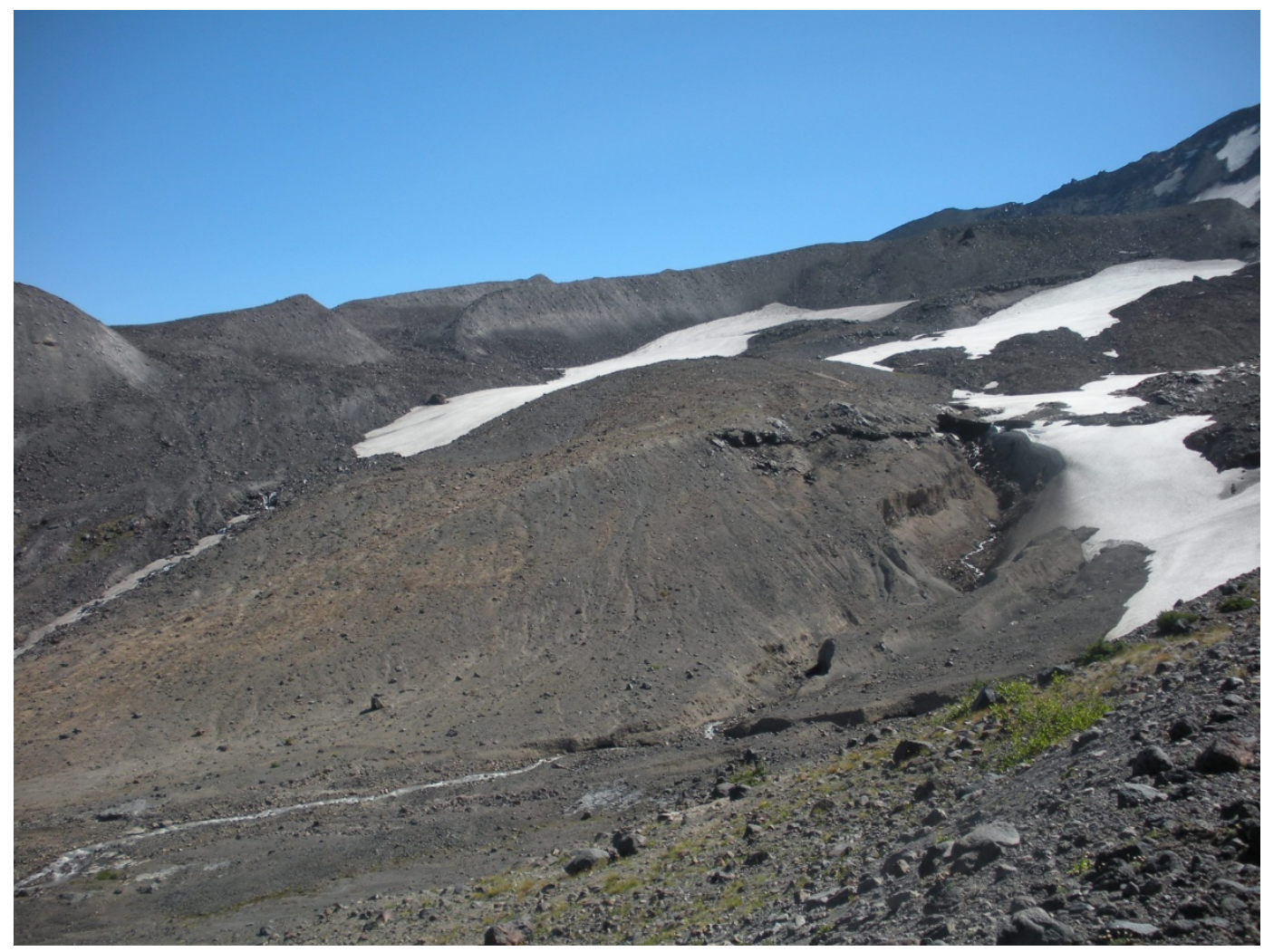

Figure 11: Initiation zone for Adams Creek Drainage. Photo taken during the summer of 2010 from GPS point 105.

\section{Basin Attributes}

The elevation of the Adams Creek Initiation Zone is about 2,140 m, on a deposit geologically mapped as Quaternary Glacial Drift (Department of Natural Resources, 2005). The total basin area is $12.7 \mathrm{~km}^{2}$, and the upper basin is $5.5 \mathrm{~km}^{2}$. The distance from the stream beginning to the glacier is zero meters, and $2.9 \mathrm{~km}^{2}$, or $53 \%$, of the upper basin is covered in glaciers. The stream is directly connected to the glacier. The highest elevation of the basin is $3,750 \mathrm{~m}$, the basin height is $2,400 \mathrm{~m}$, and the basin length is $6,500 \mathrm{~m}$. The gradient of the upper basin is $0.3,6 \%$ of the upper basin is vegetated and $11 \%$ are steep slopes. MRN is calculated as 0.67 , and the average annual precipitation is $2.6 \mathrm{~m}$. 
Table 3: Adams Creek Drainage Basin attributes.

\begin{tabular}{|c|c|c|c|c|}
\hline \multicolumn{2}{|l|}{ Factor } & Value & $\begin{array}{l}\text { All Geologic } \\
\underline{\text { Units }}\end{array}$ & $\begin{array}{l}\text { \% of Upper } \\
\text { Basin }\end{array}$ \\
\hline \multicolumn{2}{|c|}{ Elevation of initiation zone (m) } & 2140 & Ice & \\
\hline \multicolumn{2}{|c|}{ Total Basin Area $\left(\mathrm{m}^{2}\right)$} & 12694200 & Glacier & 53 \\
\hline \multicolumn{2}{|l|}{ Upper Basin Area $\left(\mathrm{m}^{2}\right)$} & 5475880 & Dacite & \\
\hline \multicolumn{2}{|c|}{ Distance from the glacier $(\mathrm{m})$} & 0 & Qvd(a) & 0 \\
\hline \multicolumn{2}{|c|}{ Glacier Area $\left(\mathrm{m}^{2}\right)$} & 2875780 & Basalt & \\
\hline \multicolumn{2}{|c|}{ Surface Connection to the Glacier } & Yes & Qvb(gt) & 0 \\
\hline \multicolumn{2}{|c|}{ Highest Elevation of the Basin (m) } & 3750 & Qvb(ri) & 0 \\
\hline \multicolumn{2}{|l|}{ Basin Height (m) } & 2400 & $\mathrm{Qvb}(\mathrm{rb})$ & 0 \\
\hline \multicolumn{2}{|l|}{ Upper Basin Length (m) } & 6500 & Andesite & \\
\hline \multicolumn{2}{|l|}{ Upper Basin Gradient } & 0.30 & Qva(a) & 16 \\
\hline \multicolumn{2}{|l|}{ Percent Vegetation } & 6 & Qva(ah) & 8 \\
\hline \multicolumn{2}{|l|}{ Percent Steep Slopes } & 11 & Qva(hb) & 0 \\
\hline \multicolumn{2}{|c|}{ Melton's Ruggedness number } & 0.67 & Qva(sb) & 0 \\
\hline \multicolumn{2}{|c|}{ Grain Size Average Sand Percent } & 64 & Qvba(Im) & 0 \\
\hline \multicolumn{2}{|c|}{ Average Annual Precipitation (m) } & 2.6 & Glacial Drift & \\
\hline \multicolumn{2}{|c|}{ Glacier Area Lost From 1904-2006 $\left(\mathrm{m}^{2}\right)$} & 325000 & Qad & 21 \\
\hline \multicolumn{2}{|c|}{ Percent Glacier area lost 1904-2006 } & -47 & Qad(md) & 0 \\
\hline \multicolumn{2}{|c|}{ Glacier Area Lost From 1998-2006 $\left(\mathrm{m}^{2}\right)$} & 840000 & Volcaniclastic & \\
\hline & Qvc(a) & 3 \\
\hline Major Geologic Units & \multicolumn{2}{|c|}{ \% of Upper Basin } & & \\
\hline Ice & \multicolumn{2}{|c|}{53} & \multirow{2}{*}{$\begin{array}{l}\text { Bedrock vs. } \\
\text { Unconsolidated }\end{array}$} & \% of Upper \\
\hline Dacite & \multicolumn{2}{|l|}{0} & & Basin \\
\hline Basalt & \multicolumn{2}{|l|}{0} & \multirow{2}{*}{$\begin{array}{l}\text { Basalt, Andesite, } \\
\text { Dacite }\end{array}$} & 21 \\
\hline Andesite & \multicolumn{2}{|l|}{24} & & $\angle 4$ \\
\hline Glacial Drift & \multirow{2}{*}{\multicolumn{2}{|c|}{$\frac{21}{3}$}} & \multirow{2}{*}{$\begin{array}{l}\text { Volcaniclastic, } \\
\text { Glacial Drift }\end{array}$} & 24 \\
\hline Volcaniclastic & & & & $\angle 4$ \\
\hline
\end{tabular}

\subsubsection{Big Muddy Creek}

Big Muddy Creek is located on the east side of Mt. Adams (Figure 12). In 2006 this drainage experienced a debris flow that traveled approximately $11,600 \mathrm{~m}$. A

coalescence of several channels eroded into debris avalanche deposits and glacial drift is the source areas for this debris flow (Figures 13 \& 15) (Darryl Lloyd, Personal Communication 2007). 


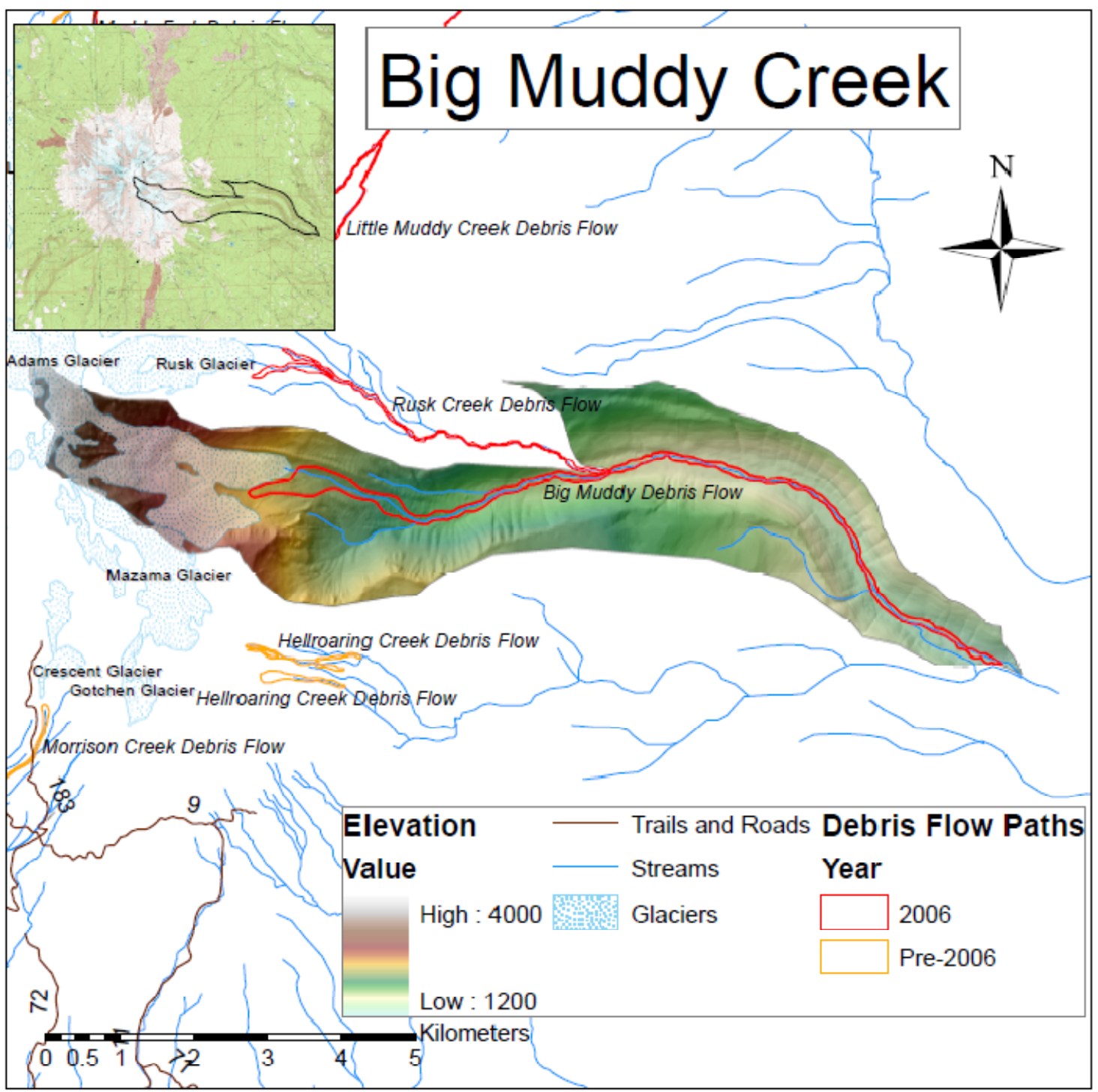

Figure 12: Map of Big Muddy Creek Drainage. Black numbers are trail and road indicators, and black numbers with white halos refer to GPS points. Initiation area includes a broad area of many small channels.

The initiation zone characteristics described for this debris flow qualify it to be classified as a headless debris flow. Big Muddy Creek is joined by Rusk Creek at an elevation of 1,300 $\mathrm{m}$. The combined deposit of these two debris flows extends to an elevation of about 1,200 m (Darryl Lloyd, Personal Communication 2007). 


\section{Reconnaissance}

The reconnaissance for Big Muddy Creek was conducted in 2007 by Darryl Lloyd. Further investigation was not conducted due to limited field season and a large study area. Based on the photos taken by Darryl Lloyd in 2007, the middle portion of the drainage exhibits erosion and incision (Figure 13). Eroded channels in glacial till and debris avalanche deposits were seen just south of the Klickitat Glacier terminus in the uppermost portion of the Big Muddy Creek drainage (Figure 14). The view from Battlement Ridge shows an enlarged channel with no vegetation on the sidewalls in the upper drainage (Figure 15).

\section{Initiation Zone}

Oblique air photos were taken during the summer of 2010 of the Big Muddy Creek Debris Flow Initiation Zone. Here, the coalescence of eroded channels is visible as well as incision in the channel (Figure 16). The initiation zone is mapped as Quaternary Glacial Drift (Qad) (Department of Natural Resources, 2005).

Sample Collection \& Sieve Results

Samples were not collected for the Big Muddy Creek Drainage due to a limited field season and a large study area. 

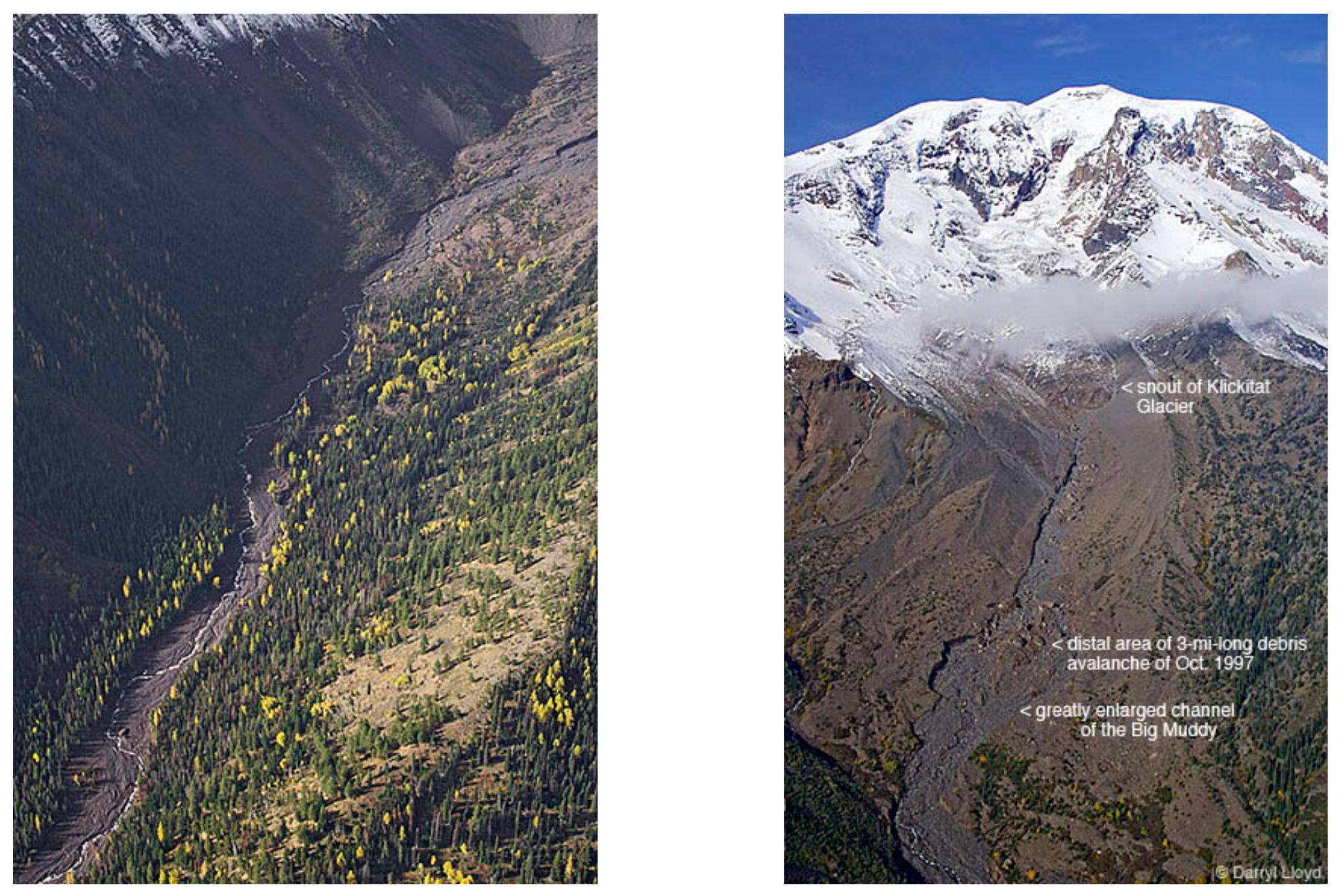

Figure 13: Middle section of the Big Muddy Creek channel just below the upper Figure 14: Big Muddy Creek debris flow channel just below the canyon. View is to the west. Photo taken by Darryl Lloyd on October 14, 2007. K Klickitat Glacier. Photo taken by Darryl Lloyd on October $13,2007$. 


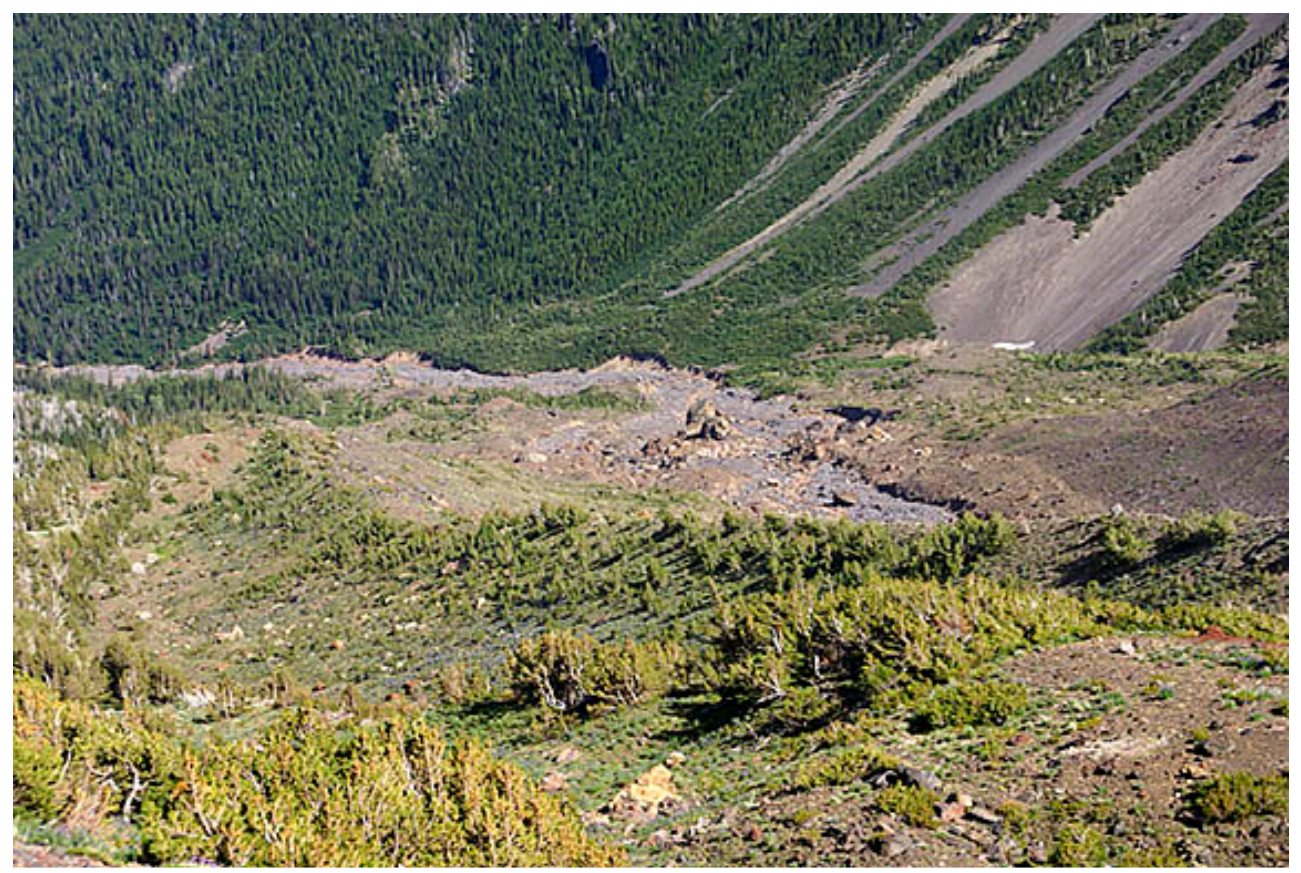

Figure 15: Big Muddy Creek channel enlarged after debris flow. Photo taken by Darryl Lloyd looking south from Battlement Ridge 7/23/2007.

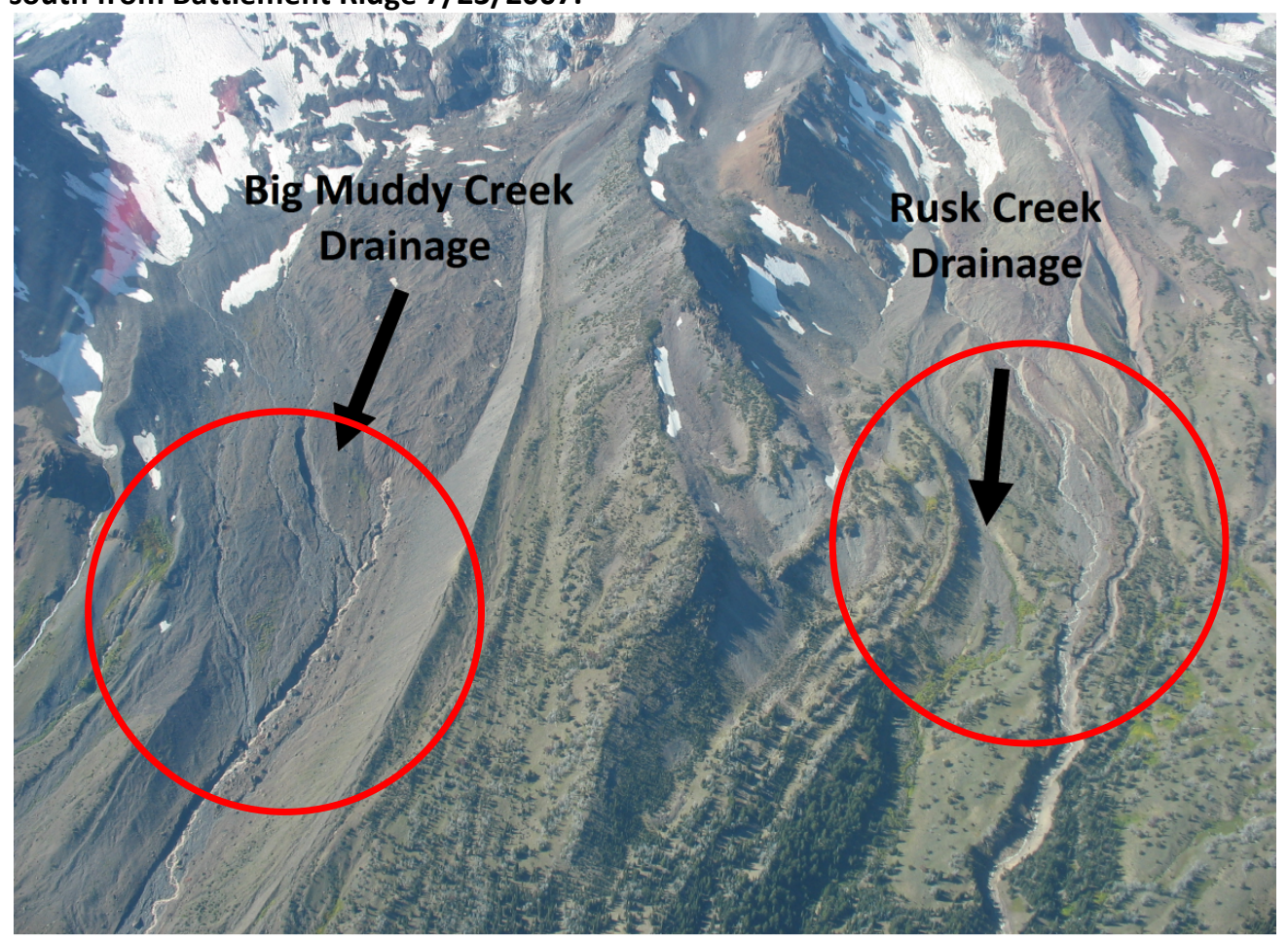

Figure 16: Oblique air photo showing the Big Muddy Creek (left) Initiation Zone as well as the Rusk Creek (right) initiation zone. Areas of coalescence are circled in red, drainage labels are in black with black arrows pointing down slope. Photo taken September 30, 2010. 
Table 4: Big Muddy Creek Basin attributes.

\begin{tabular}{|c|c|c|c|c|}
\hline \multicolumn{2}{|l|}{ Factor } & $\underline{\text { Value }}$ & $\begin{array}{l}\text { All Geologic } \\
\underline{\text { Units }}\end{array}$ & $\begin{array}{l}\text { \% of Upper } \\
\text { Basin }\end{array}$ \\
\hline \multicolumn{2}{|c|}{ Elevation of initiation zone (m) } & 2170 & Ice & \\
\hline \multicolumn{2}{|c|}{ Total Basin Area $\left(\mathrm{m}^{2}\right)$} & 22733820 & $\overline{\text { Glacier }}$ & 44 \\
\hline \multicolumn{2}{|l|}{ Upper Basin Area $\left(\mathrm{m}^{2}\right)$} & 7019730 & Dacite & \\
\hline \multicolumn{2}{|c|}{ Distance from the glacier $(\mathrm{m})$} & 0 & Qvd(a) & 0 \\
\hline \multicolumn{2}{|c|}{ Glacier Area $\left(\mathrm{m}^{2}\right)$} & 3117820 & Basalt & \\
\hline \multicolumn{2}{|c|}{ Surface Connection to the Glacier } & Yes & Qvb(gt) & 0 \\
\hline \multicolumn{2}{|c|}{ Highest Elevation of the Basin (m) } & 3750 & Qvb(ri) & 0 \\
\hline \multicolumn{2}{|c|}{ Basin Height $(\mathrm{m})$} & 2870 & Qvb(rb) & 0 \\
\hline \multicolumn{2}{|l|}{ Upper Basin Length (m) } & 6600 & Andesite & \\
\hline \multicolumn{2}{|l|}{ Upper Basin Gradient } & 0.4 & Qva(a) & 21 \\
\hline \multicolumn{2}{|l|}{ Percent Vegetation } & 2 & Qva(ah) & 0 \\
\hline \multicolumn{2}{|l|}{ Percent Steep Slopes } & 31 & Qva(hb) & 4 \\
\hline \multicolumn{2}{|c|}{ Melton's Ruggedness number } & 0.60 & Qva(sb) & 0 \\
\hline \multicolumn{2}{|c|}{ Grain Size Average Sand Percent } & None & Qvba(Im) & 0 \\
\hline \multicolumn{2}{|c|}{ Average Annual Precipitation (m) } & 1.8 & Glacial Drift & \\
\hline \multicolumn{2}{|c|}{ Glacier Area Lost From 1904-2006 $\left(\mathrm{m}^{2}\right)$} & 244000 & Qad & 31 \\
\hline \multicolumn{2}{|c|}{ Percent Glacier area lost 1904-2006 } & -46 & Qad(md) & 0 \\
\hline \multicolumn{2}{|c|}{ Glacier Area Lost From 1998-2006 $\left(\mathrm{m}^{2}\right)$} & 210000 & Volcaniclastic & \\
\hline & & Qvc(a) & 0 \\
\hline Major Geologic Units & \multicolumn{2}{|c|}{ \% of Upper Basin } & & \\
\hline Ice & \multicolumn{2}{|c|}{44} & \multirow{2}{*}{$\begin{array}{l}\text { Bedrock vs. } \\
\text { Unconsolidated }\end{array}$} & \% of Upper \\
\hline Dacite & \multicolumn{2}{|l|}{0} & & Basin \\
\hline Basalt & \multicolumn{2}{|l|}{0} & \multirow{2}{*}{$\begin{array}{l}\text { Basalt, Andesite, } \\
\text { Dacite }\end{array}$} & \\
\hline Andesite & \multicolumn{2}{|l|}{25} & & 25 \\
\hline Glacial Drift & \multicolumn{2}{|l|}{31} & \multirow{2}{*}{$\begin{array}{l}\text { Volcaniclastic, } \\
\text { Glacial Drift }\end{array}$} & \\
\hline Volcaniclastic & \multicolumn{2}{|l|}{0} & & 31 \\
\hline
\end{tabular}

\section{Basin Attributes}

The elevation of the Big Muddy Creek Initiation Zone is about 2,170 m, on a deposit geologically mapped as Quaternary Glacial Drift (Department of Natural Resources, 2005). The total basin area is $22.7 \mathrm{~km}^{2}$, and the upper basin is $7.0 \mathrm{~km}^{2}$. The distance from the stream beginning to the glacier is zero meters, and $3.1 \mathrm{~km}^{2}$, or $44 \%$, of the upper basin is covered in glaciers. The stream is directly connected to the glacier.

The highest elevation of the basin is $3,750 \mathrm{~m}$, the basin height is $2,870 \mathrm{~m}$, and the basin 
length is $6,500 \mathrm{~m}$. The gradient of the upper basin is $0.4,2 \%$ of the upper basin is vegetated and $31 \%$ are steep slopes. MRN is calculated as 0.60 , and the average annual precipitation is $1.8 \mathrm{~m}$.

\subsubsection{Bird Creek}

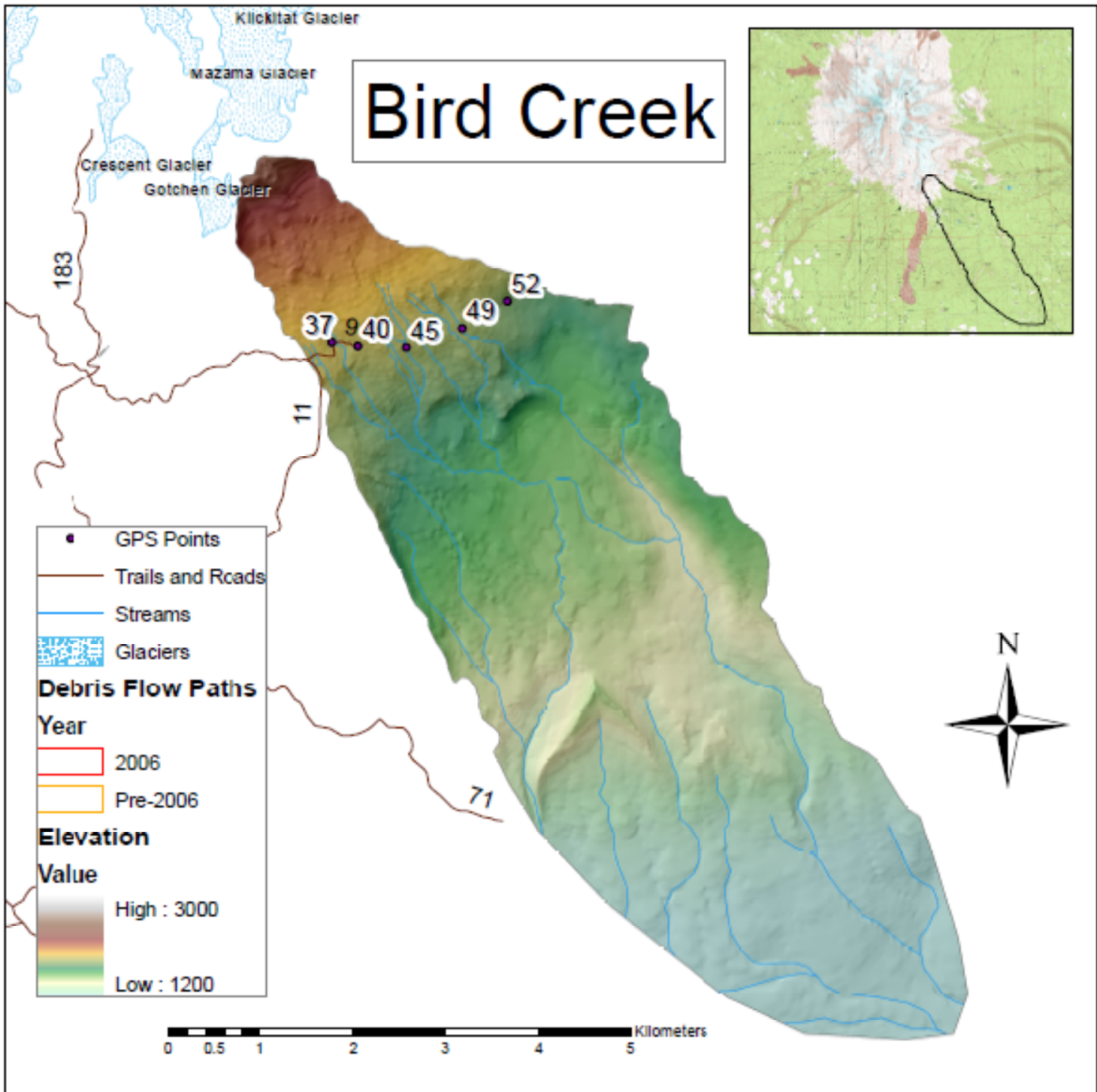

Figure 17: Map of Bird Creek Drainage. Black numbers are trail and road indicators, black numbers with white halos refer to GPS points. 
Bird Creek is a heavily vegetated drainage on the southeast side of Mt. Adams

(Figure 17). Located in the Yakama Reservation portion of the mountain, it is a popular tourist destination with several campgrounds and trails. It is a favorite scenic spot for hikers and campers. No debris flow activity was observed for this drainage, and no evidence of past debris flows was observed on the oblique air photos.

\section{Reconnaissance}

Initial reconnaissance was conducted in the summer of 2009. Hiking across The Bird Creek Basin on Trail 9, many small creeks trickle by and highly vegetated meadows were frequently encountered (Figure 18).

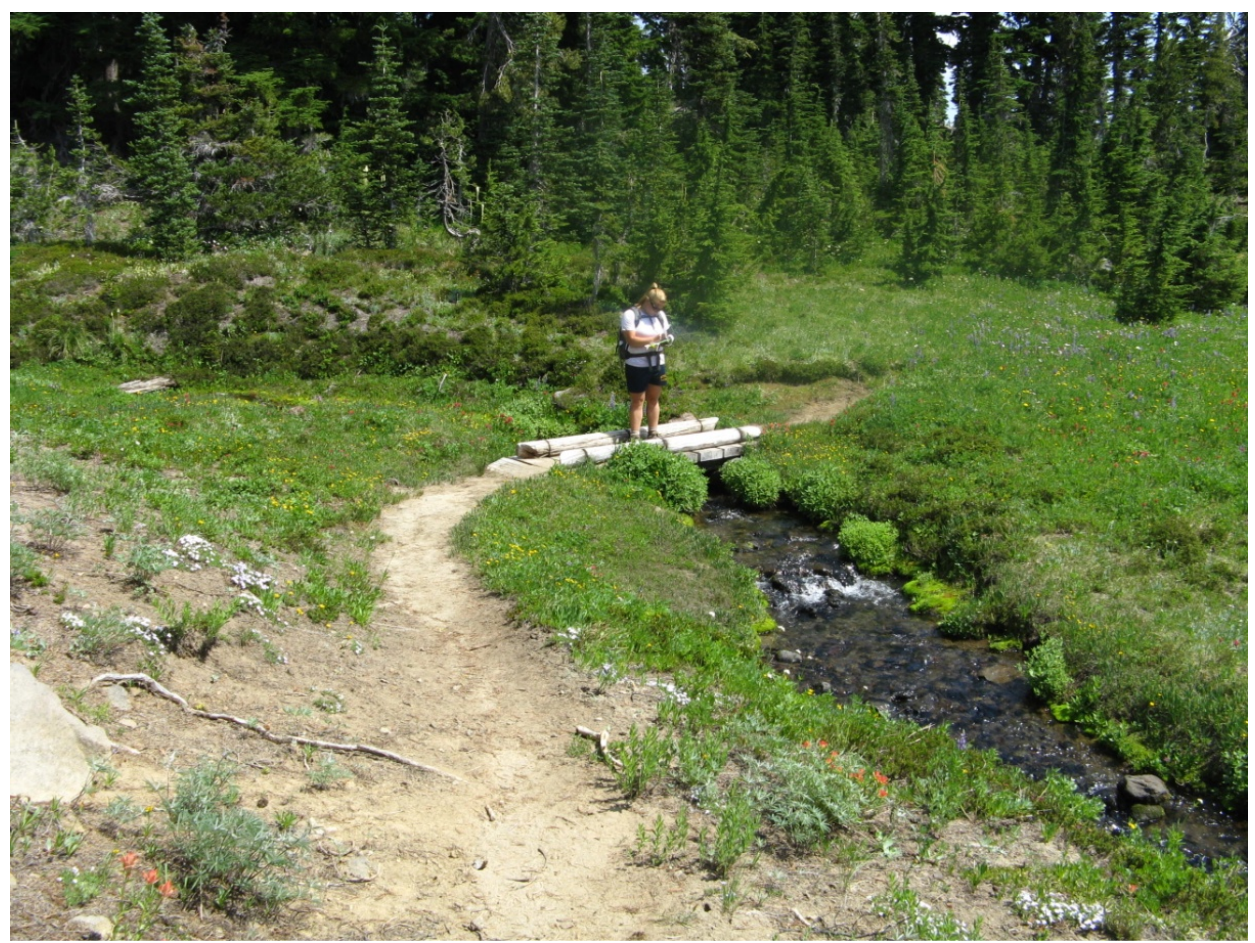

Figure 18: Photo of Bird Creek Drainage. Typical low gradient and abundant vegetation is visible. Photo taken during the summer of 2009. 
Initiation Zone, Sample Collection, and Sieve Results

Due to lack of debris flow activity, a limited field season and a large study area, samples were not collected for Bird Creek.

Table 5: Bird Creek Basin attributes.

\begin{tabular}{|c|c|c|c|c|}
\hline \multicolumn{2}{|l|}{ Factor } & $\underline{\text { Value }}$ & $\begin{array}{l}\text { All Geologic } \\
\text { Units }\end{array}$ & $\begin{array}{l}\text { \% of Upper } \\
\text { Basin }\end{array}$ \\
\hline \multicolumn{2}{|c|}{ Elevation of initiation zone $(\mathrm{m})$} & None & Ice & \\
\hline \multicolumn{2}{|c|}{ Total Basin Area $\left(\mathrm{m}^{2}\right)$} & 31678250 & Glacier & 0 \\
\hline \multicolumn{2}{|l|}{ Upper Basin Area $\left(\mathrm{m}^{2}\right)$} & 5266080 & Dacite & \\
\hline \multicolumn{2}{|c|}{ Distance from the glacier $(\mathrm{m})$} & 1600 & Qvd(a) & 0 \\
\hline \multicolumn{2}{|c|}{ Glacier Area $\left(\mathrm{m}^{2}\right)$} & 0 & Basalt & \\
\hline \multicolumn{2}{|c|}{ Surface Connection to the Glacier } & No & Qvb(gt) & 0 \\
\hline \multicolumn{2}{|c|}{ Highest Elevation of the Basin (m) } & 2400 & Qvb(ri) & 0 \\
\hline \multicolumn{2}{|c|}{ Basin Height $(\mathrm{m})$} & 1750 & Qvb(rb) & 0 \\
\hline \multicolumn{2}{|l|}{ Upper Basin Length (m) } & 3720 & Andesite & \\
\hline \multicolumn{2}{|l|}{ Upper Basin Gradient } & 0.19 & Qva(a) & 73 \\
\hline \multicolumn{2}{|l|}{ Percent Vegetation } & 39 & Qva(ah) & 0 \\
\hline \multicolumn{2}{|l|}{ Percent Steep Slopes } & 1 & Qva(hb) & 0 \\
\hline \multicolumn{2}{|c|}{ Melton's Ruggedness number } & 0.31 & Qva(sb) & 0 \\
\hline \multicolumn{2}{|c|}{ Grain Size Average Sand Percent } & None & Qvba(Im) & 0 \\
\hline \multicolumn{2}{|c|}{ Average Annual Precipitation (m) } & 1.8 & Glacial Drift & \\
\hline \multicolumn{2}{|c|}{ Glacier Area Lost From 1904-2006 $\left(\mathrm{m}^{2}\right)$} & 620000 & Qad & 27 \\
\hline \multicolumn{2}{|c|}{ Percent Glacier area lost 1904-2006 } & -78 & Qad(md) & 0 \\
\hline \multicolumn{2}{|c|}{ Glacier Area Lost From 1998-2006 $\left(\mathrm{m}^{2}\right)$} & 190000 & Volcaniclastic & \\
\hline \multicolumn{3}{|c|}{ (5) } & Qvc(a) & 0 \\
\hline Major Geologic Units & \multicolumn{2}{|c|}{ \% of Upper Basin } & \multirow{3}{*}{$\begin{array}{l}\text { Bedrock vs. } \\
\text { Unconsolidated }\end{array}$} & \\
\hline Ice & \multicolumn{2}{|c|}{0} & & \% of Upper \\
\hline Dacite & \multicolumn{2}{|l|}{0} & & Basin \\
\hline Basalt & \multicolumn{2}{|l|}{0} & \multirow{2}{*}{$\begin{array}{l}\text { Basalt, Andesite, } \\
\text { Dacite }\end{array}$} & \\
\hline Andesite & \multicolumn{2}{|l|}{73} & & 13 \\
\hline Glacial Drift & \multicolumn{2}{|l|}{27} & \multirow{2}{*}{$\begin{array}{l}\text { Volcaniclastic, } \\
\text { Glacial Drift }\end{array}$} & \\
\hline Volcaniclastic & \multicolumn{2}{|l|}{0} & & 21 \\
\hline
\end{tabular}

\section{Basin Attributes}

The total Bird Creek basin area is $31.7 \mathrm{~km}^{2}$, and the upper basin is $5.3 \mathrm{~km}^{2}$. The distance from the stream beginning to any glaciated area is $1,600 \mathrm{~m}$ and $0 \mathrm{~m}^{2}$, or $0 \%$, of the upper basin is covered in glaciers. The stream is not directly connected to the 
glacier. The highest elevation of the basin is $2,400 \mathrm{~m}$, the basin height is $1,750 \mathrm{~m}$, and the basin length is $3,720 \mathrm{~m}$. The gradient of the upper basin is $0.19,39 \%$ of the upper basin is vegetated and $1 \%$ are steep slopes. MRN is calculated as 0.31 , and the average annual precipitation is $1.8 \mathrm{~m}$.

\subsubsection{Cascade Creek}

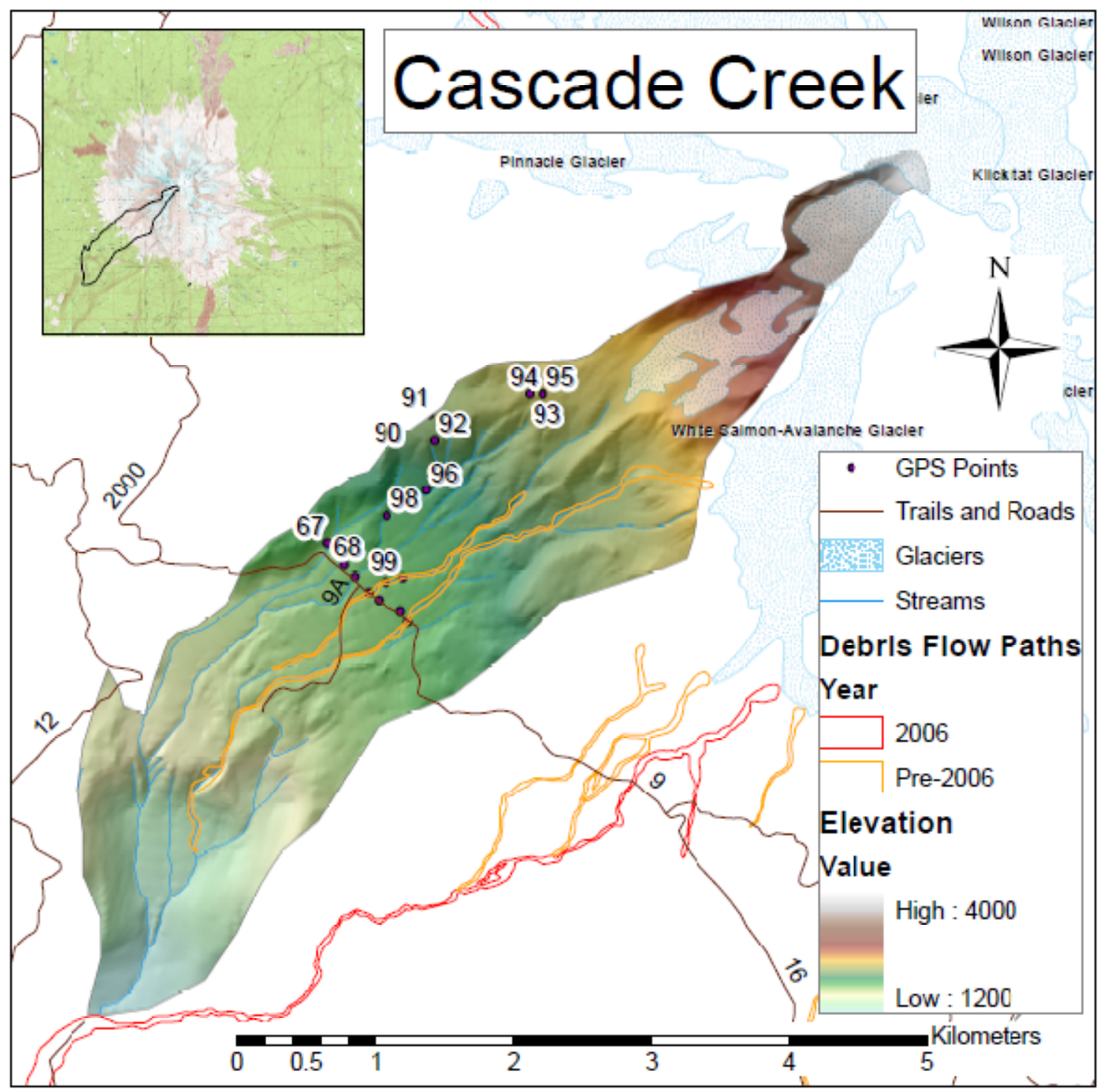

Figure 19: Map of Cascade Creek Drainage. Black numbers are trail and road indicators, black numbers with white halos refer to GPS points. 
Cascade Creek is located on the southwest side of Mt. Adams (Figure 19). It is a slightly more secluded drainage but is accessible from Trail 9. This drainage had evidence of previous debris flow activity. This debris flow activity appeared older than some of the other drainages in the field, based on more vegetation on the banks and in areas of previous incision (Figure 20). Orthophoto analysis indicated little change between the pre storm 2006 photo and the 2009 photo. These facts lead to the conclusion that this drainage experienced a debris flow in the past but not during the 2006 storm.

\section{Reconnaissance}

Initial reconnaissance was conducted in the summer of 2009. At the location of Trail 9, sandy mud coated boulders were found at the crossing with Trail 9 and incision was visible up the drainage (Figure 20). Vegetation was more abundant in the drainage sidewalls and in the channel than in other drainages that experienced debris flows as a result of the 2006 storm.

\section{Initiation Zone}

During the summer of 2010 the upper Cascade Creek Drainage was explored by hiking a ridge between the Horseshoe Creek and Cascade Creek drainages. Boulder levees were encountered in several of the drainages but were small and had collapsed in several locations (Figure 21). No visible initiation zone was identified for the Cascade Creek drainage. 


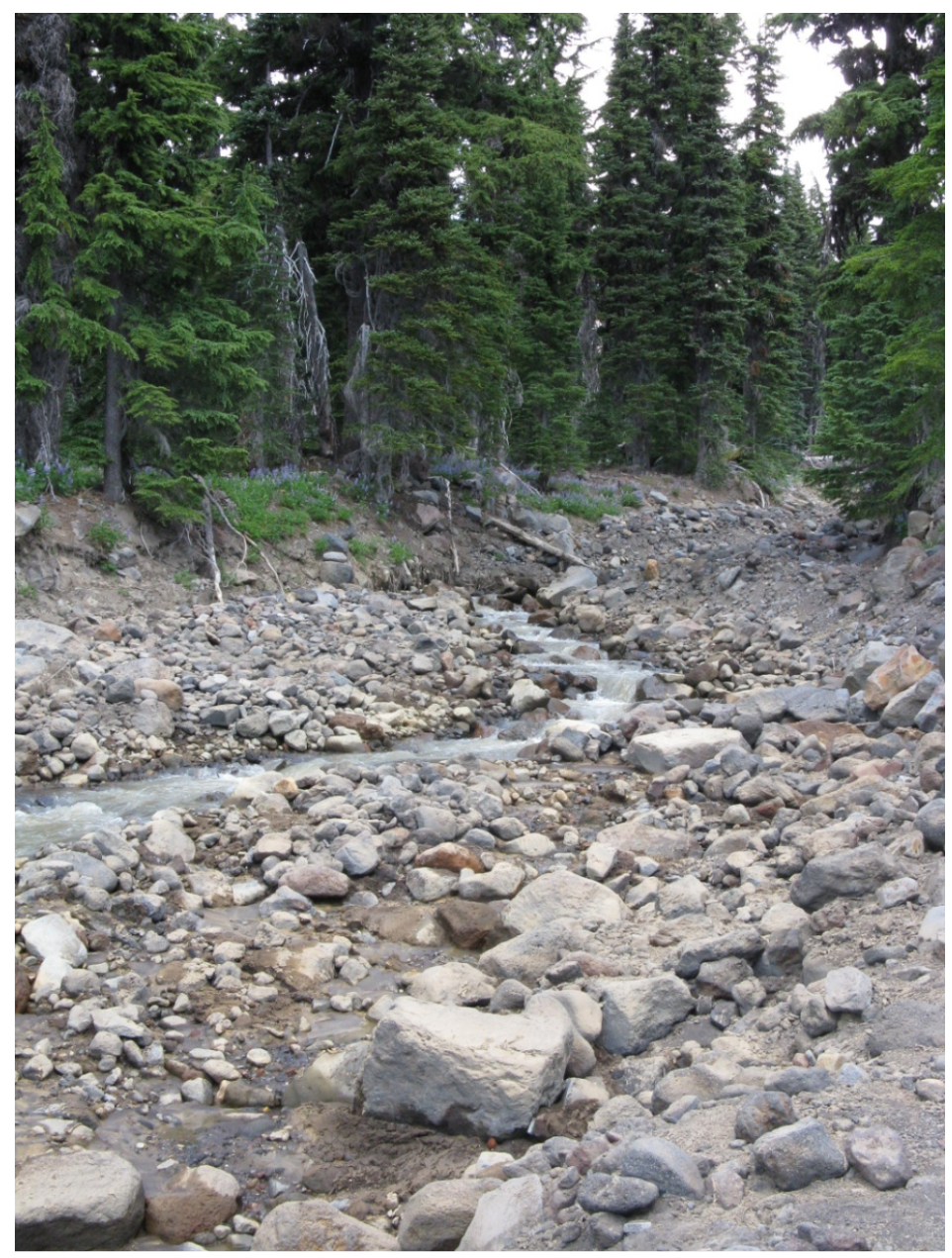

Figure 20: Sandy mud coasted boulder deposit in the lower Cascade Creek Drainage. Vegetation on the stream banks is also visible. Photo taken in the summer of 2009.

Sample Collection

Three soil samples for Cascade Creek were taken from GPS point 95. This location was chosen because the elevation was similar to that of other debris flow initiation zones. It was taken in an area geologically mapped as Quaternary Glacial Drift (Qad) (Department of Natural Resources, 2005). 
Sieve Results

Samples from Cascade Creek drainage are presented in Table 6 below along with average values. Bulk density was measured at $1.6 \mathrm{~g} / \mathrm{cm}^{3}$, and the sample contained $34 \%$ gravel, $64 \%$ sand and $3 \%$ fines.

Table 6: Cascade Creek sieve results, sample 95 subsets 1, 2 and 3. See Table 1 for exact size definitions. Bottom row holds the average values.

\begin{tabular}{|c|c|c|c|c|c|c|c|}
\hline \multirow{2}{*}{$\#$} & \multirow{2}{*}{$\begin{array}{c}\text { Bulk Density } \\
(\mathrm{g} / \mathrm{cm} 3)\end{array}$} & \multirow{2}{*}{ Gravel } & Sand & \multicolumn{3}{|c|}{ Sand Distribution } & \multirow{2}{*}{$\begin{array}{c}\text { Silt \& } \\
\text { Clay }\end{array}$} \\
\cline { 5 - 7 } & & & & Coarse Sand & Medium Sand & Fine Sand & \\
\hline 1 & 1.6 & 31 & 65 & 49 & 10 & 6 & 2.9 \\
2 & 1.7 & 18 & 77 & 51 & 15 & 11 & 4.9 \\
3 & 1.6 & 51 & 50 & 35 & 12 & 2 & 0.5 \\
\hline $\boldsymbol{x}$ & $1.6 \pm 0$ & $34 \pm 16.5$ & $64 \pm 14.2$ & $45 \pm 8.8$ & $12 \pm 2.5$ & $7 \pm 4.7$ & $2.8 \pm 2.2$ \\
\hline
\end{tabular}

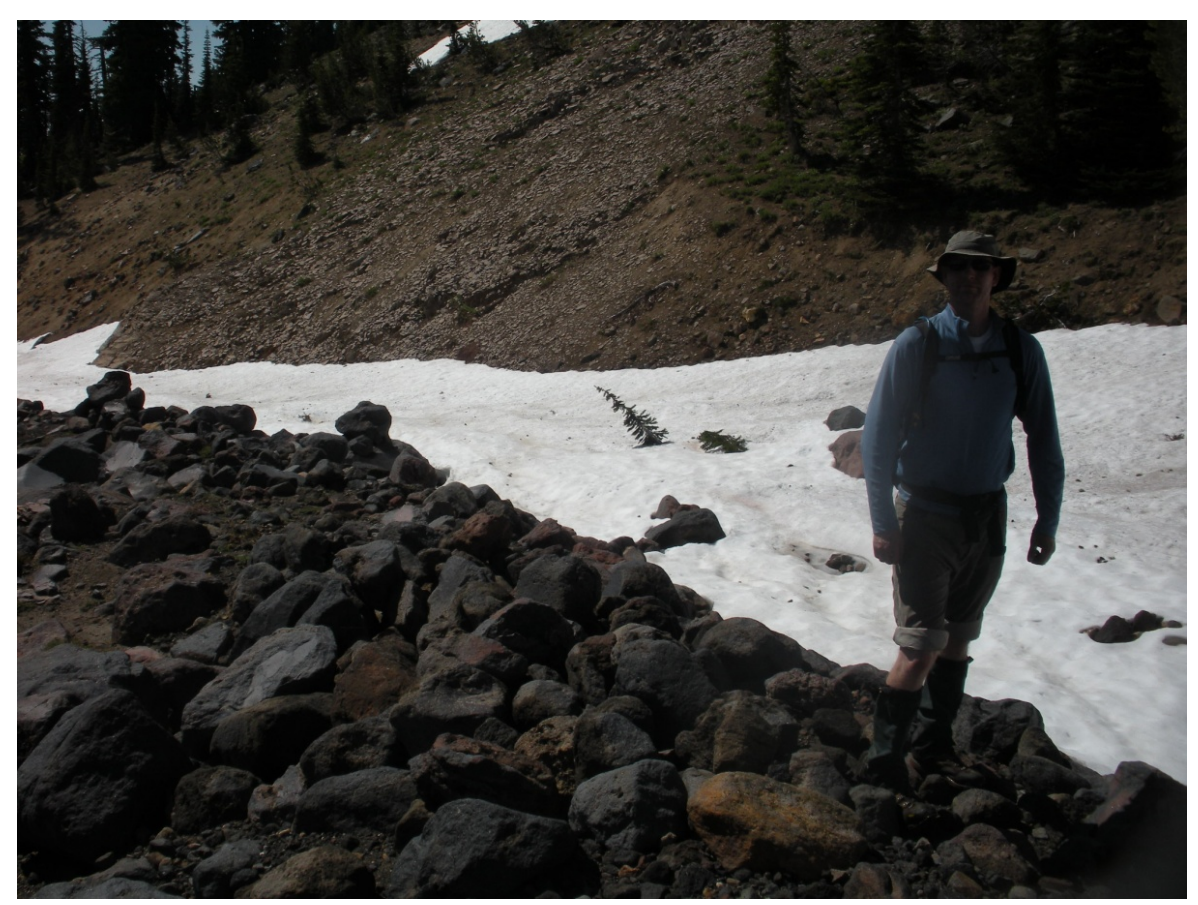

Figure 21: Boulder levee in the Cascade Creek Drainage. Photo taken during the summer of 2010.

\section{Basin Attributes}

The total Cascade Creek Basin area is $10.8 \mathrm{~km}^{2}$, and the upper basin is $5.0 \mathrm{~km}^{2}$. The distance from the stream beginning to the glacier is 130 meters and $0.9 \mathrm{~km}^{2}$, or 
$20 \%$, of the upper basin is covered in glaciers. The stream is directly connected to the

glacier. The highest elevation of the basin is $3,710 \mathrm{~m}$, the basin height is $2,570 \mathrm{~m}$, and

the basin length is $5,110 \mathrm{~m}$. The gradient of the upper basin is $0.37,6 \%$ of the upper

basin is vegetated and $11 \%$ are steep slopes. MRN is calculated as 0.78 , and the average

annual precipitation is $2.9 \mathrm{~m}$.

Table 7: Cascade Creek Basin attributes.

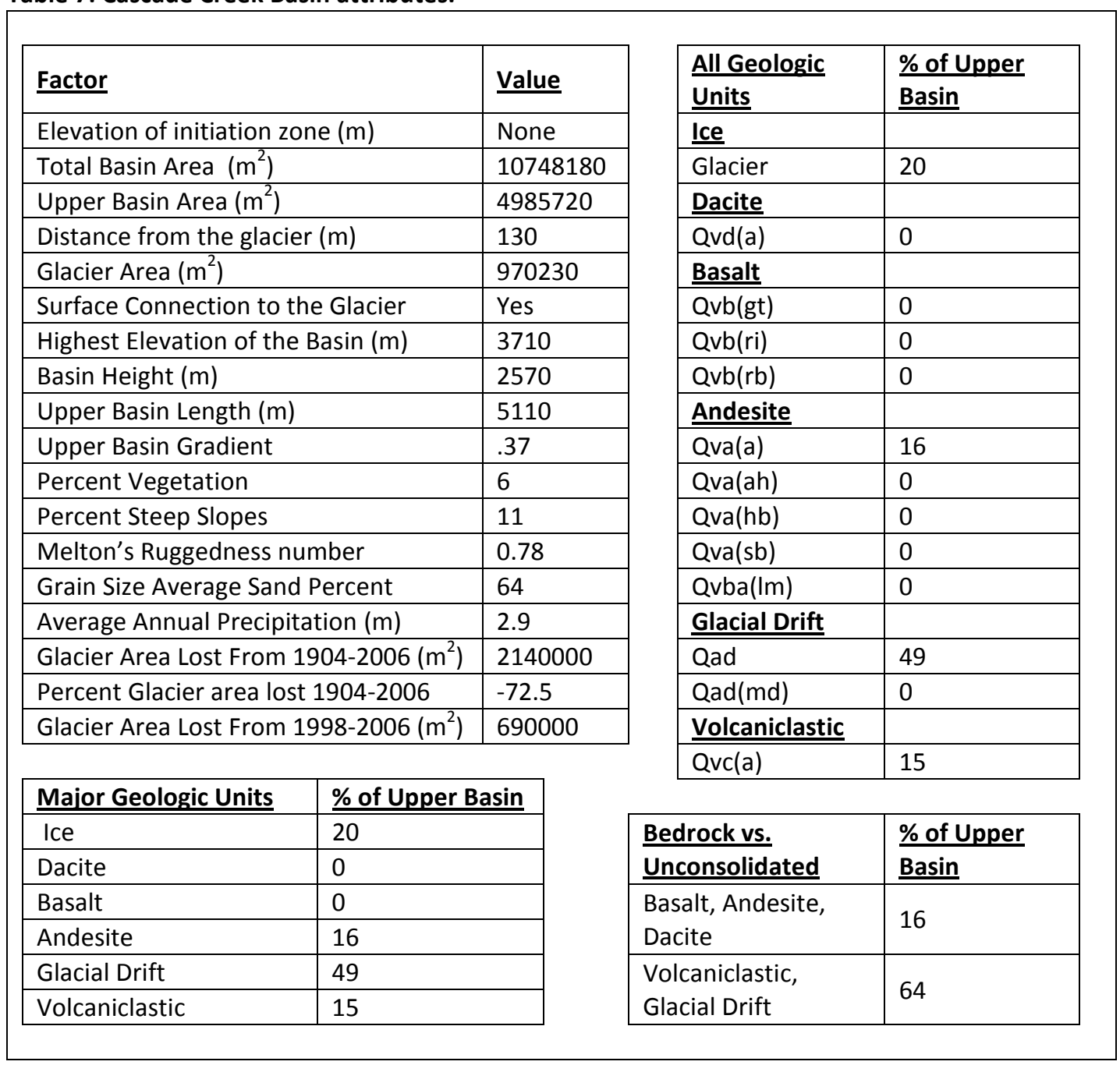




\subsubsection{Crofton Creek}

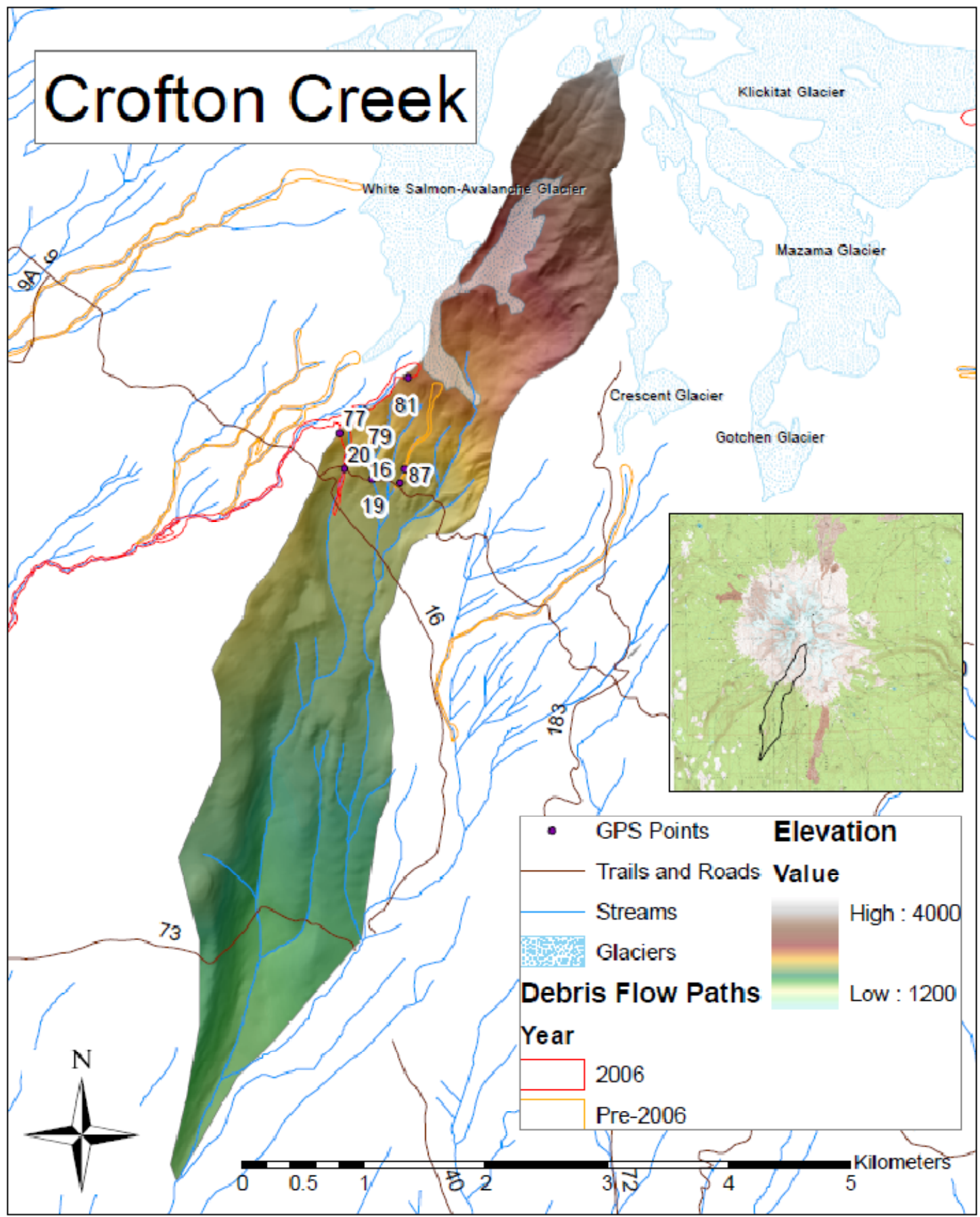

Figure 22: Map of Crofton Creek Drainage. Black numbers are trail and road indicators, black numbers with white halos refer to GPS points. 
Crofton Creek is located on the southwest side of Mt. Adams (Figure 22). It is a moderately secluded drainage but is accessible from Trails 16 and 9. This drainage had evidence of debris flow activity at two crossings with Trail 9. In one location, the debris flow initiated in the Salt Creek Drainage and spilled into the Crofton Creek Drainage. At another location, the debris flow most likely occurred before the 2006 storm. Therefore, because this project is emphasizing initiation mechanisms, this drainage was determined to not have initiated a 2006 debris flow but to have pre-2006 debris flow deposits.

\section{Reconnaissance}

Initial reconnaissance was conducted in the summer of 2009. At GPS point 16 there was evidence of previous incision and bark ripped away from trees. Similar to the Cascade Creek Drainage, however, there was vegetation on the sides of the bank and the debris flow activity appeared older than 2006 (Figure 23). At GPS point 20, extreme incision and several down trees with bark ripped away were present (Figure 24). Looking up the mountain at this location was clear channelized erosion coming over the ridge. Orthophoto analysis looked at the difference in 2006 and 2009 photos for both GPS point 16 and 20. For GPS point 16 there was a slight difference but no evidence that significant debris flow activity had occurred since 2006. For GPS point 20 there is a clear difference, and this difference is obviously traced from the debris flow that initiated in the Salt Creek Drainage. 


\section{Initiation Zone}

During the summer of 2009 the upper Crofton Creek Drainage was explored by hiking a ridge between the Salt Creek and Crofton Creek drainages. It was found that the debris flow activity at GPS point 20 had spilled over from a debris flow that initiated in the Salt Creek Drainage. This debris flow surged into the Crofton Creek Drainage in at least two locations. An initiation zone for the debris flow deposit at GPS point 16 was not found.

Sample Collection \& Sieve Results

Due to lack of 2006 debris flow initiation, a limited field season and a large study area, samples were not collected for Crofton Creek.

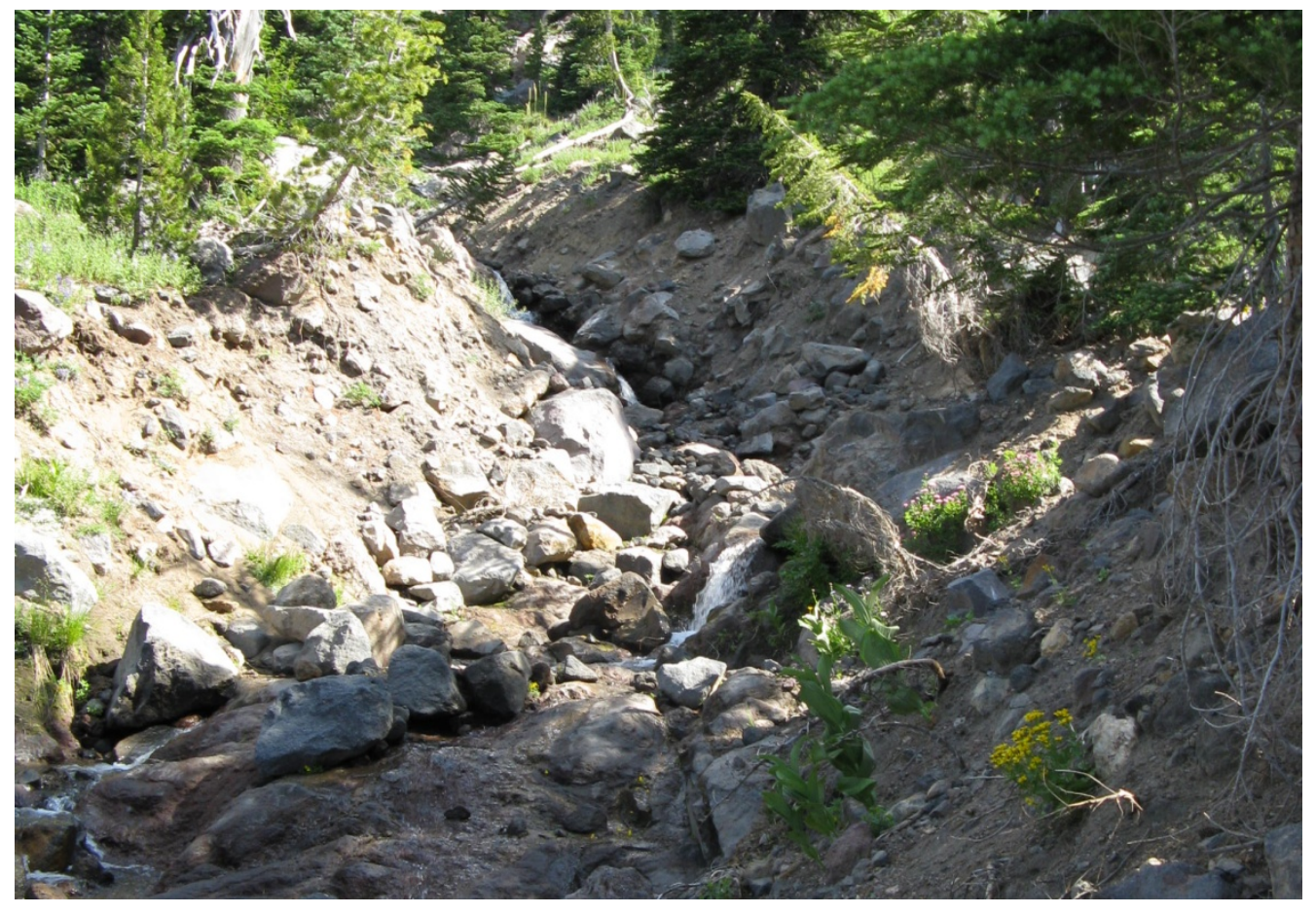

Figure 23: Photo of the Crofton Creek Drainage at GPS point 16. Older looking channel incision and bank vegetation is visible. Photo taken during the summer of 2009. 


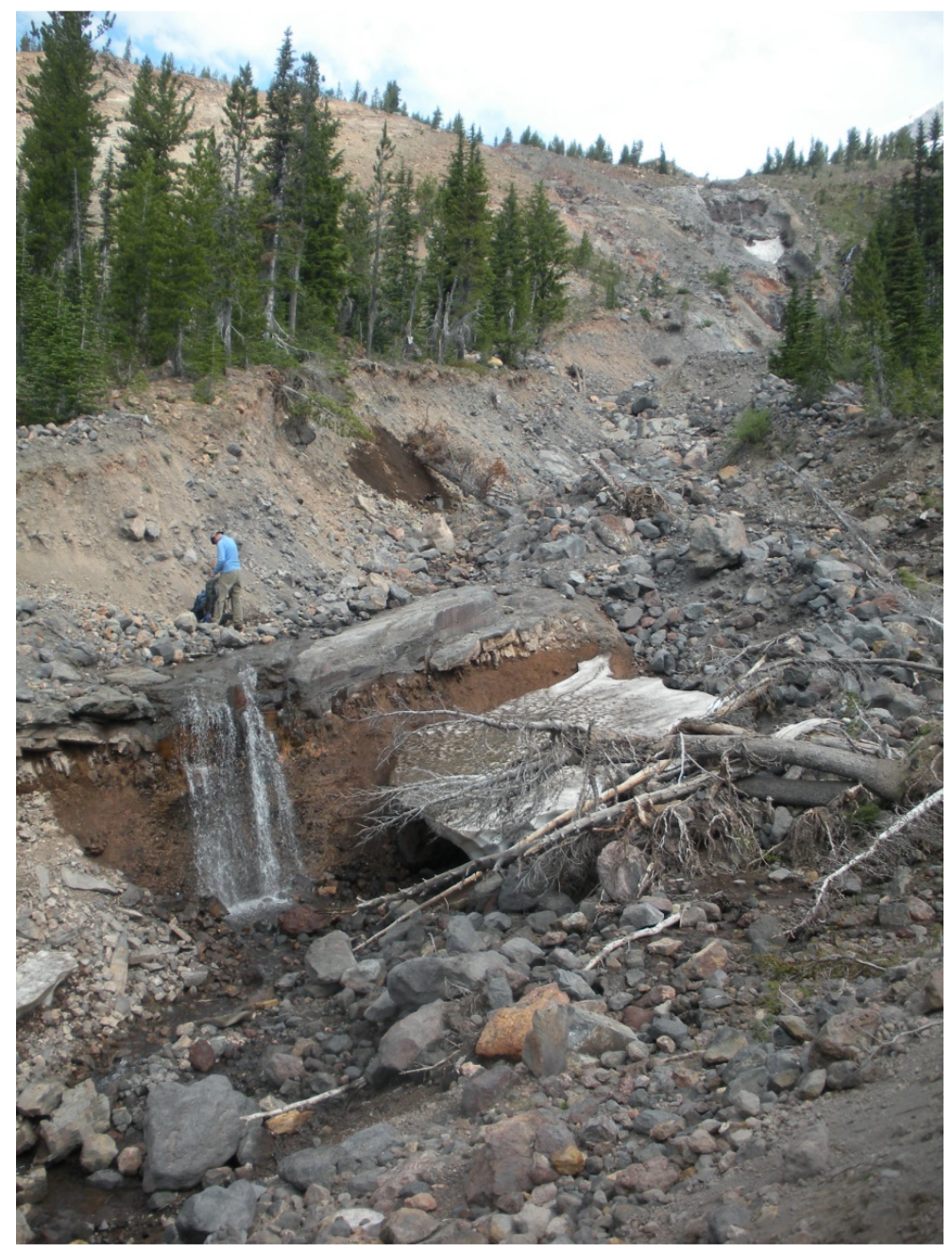

Figure 24: Photo of the Crofton Creek Drainage at GPS point 20 where debris flow activity from Salt Creek spilled over the ridge. Down trees with bark ripped away are visible in the foreground. Photo was taken during the summer of 2010.

\section{Basin Attributes}

The total Crofton Creek Basin area is $10.0 \mathrm{~km}^{2}$, and the upper basin is $4.0 \mathrm{~km}^{2}$.

The distance from the stream beginning to the glacier is zero meters, and $0.4 \mathrm{~km}^{2}$, or 10

$\%$, of the upper basin is covered in glaciers. The stream is directly connected to the glacier. The highest elevation of the basin is $3,530 \mathrm{~m}$, the basin height is $2,280 \mathrm{~m}$, and 
the basin length is $4,390 \mathrm{~m}$. The gradient of the upper basin is $0.4,14 \%$ of the upper basin is vegetated and $24 \%$ are steep slopes. MRN is calculated as 0.72 , and the average annual precipitation is $2.4 \mathrm{~m}$.

Table 8: Crofton Creek Drainage Basin Attributes

\begin{tabular}{|c|c|c|c|c|}
\hline \multicolumn{2}{|l|}{$\underline{\text { Factor }}$} & Value & $\begin{array}{l}\text { All Geologic } \\
\text { Units }\end{array}$ & $\begin{array}{l}\text { \% of Upper } \\
\text { Basin }\end{array}$ \\
\hline \multicolumn{2}{|c|}{ Elevation of initiation zone $(\mathrm{m})$} & None & Ice & \\
\hline \multicolumn{2}{|c|}{ Total Basin Area $\left(\mathrm{m}^{2}\right)$} & 9954410 & Glacier & 10 \\
\hline \multicolumn{2}{|l|}{ Upper Basin Area $\left(\mathrm{m}^{2}\right)$} & 4046620 & Dacite & \\
\hline \multicolumn{2}{|c|}{ Distance from the glacier $(\mathrm{m})$} & 0 & Qvd(a) & 0 \\
\hline \multicolumn{2}{|c|}{ Glacier Area $\left(\mathrm{m}^{2}\right)$} & 407870 & Basalt & \\
\hline \multicolumn{2}{|c|}{ Surface Connection to the Glacier } & Yes & Qvb(gt) & 0 \\
\hline \multicolumn{2}{|c|}{ Highest Elevation of the Basin (m) } & 3530 & Qvb(ri) & 0 \\
\hline \multicolumn{2}{|c|}{ Basin Height $(\mathrm{m})$} & 2280 & $\mathrm{Qvb}(\mathrm{rb})$ & 0 \\
\hline \multicolumn{2}{|l|}{ Upper Basin Length (m) } & 4390 & Andesite & \\
\hline \multicolumn{2}{|l|}{ Upper Basin Gradient } & 0.40 & Qva(a) & 59 \\
\hline \multicolumn{2}{|l|}{ Percent Vegetation } & 14 & Qva(ah) & 0 \\
\hline \multicolumn{2}{|l|}{ Percent Steep Slopes } & 24 & Qva(hb) & 0 \\
\hline \multicolumn{2}{|c|}{ Melton's Ruggedness number } & 0.72 & Qva(sb) & 0 \\
\hline \multicolumn{2}{|c|}{ Grain Size Average Sand Percent } & None & Qvba(Im) & 0 \\
\hline \multicolumn{2}{|c|}{ Average Annual Precipitation (m) } & 2.4 & Glacial Drift & \\
\hline \multicolumn{2}{|c|}{ Glacier Area Lost From 1904-2006 $\left(\mathrm{m}^{2}\right)$} & 1230000 & Qad & 20 \\
\hline \multicolumn{2}{|c|}{ Percent Glacier area lost 1904-2006 } & -59 & Qad(md) & 5 \\
\hline \multicolumn{2}{|c|}{ Glacier Area Lost From 1998-2006 $\left(\mathrm{m}^{2}\right)$} & 490000 & Volcaniclastic & \\
\hline \multicolumn{3}{|c|}{ 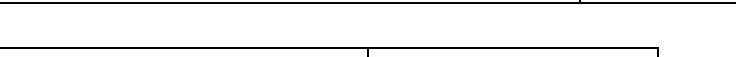 } & Qvc(a) & 6 \\
\hline Major Geologic Units & \multicolumn{2}{|c|}{ \% of Upper Basin } & & \\
\hline Ice & \multicolumn{2}{|c|}{10} & \multirow{2}{*}{$\begin{array}{l}\text { Bedrock vs. } \\
\text { Unconsolidated }\end{array}$} & \% of Upper \\
\hline Dacite & \multicolumn{2}{|l|}{0} & & Basin \\
\hline Basalt & \multicolumn{2}{|l|}{0} & \multirow{2}{*}{$\begin{array}{l}\text { Basalt, Andesite, } \\
\text { Dacite }\end{array}$} & 50 \\
\hline Andesite & \multicolumn{2}{|l|}{59} & & 59 \\
\hline Glacial Drift & \multicolumn{2}{|l|}{25} & \multirow{2}{*}{$\begin{array}{l}\text { Volcaniclastic, } \\
\text { Glacial Drift }\end{array}$} & 21 \\
\hline Volcaniclastic & \multicolumn{2}{|l|}{6} & & 31 \\
\hline
\end{tabular}

\subsubsection{East Fork}

East Fork Drainage is located on the northwest corner of Mt. Adams (Figure 25).

This drainage is remote with access from Trails 113 and 10. This drainage is not very wide, and is wedged between the Adams Creek and Killen Creek drainages. No debris 
flow activity was observed for this drainage, and no evidence of past debris flows were observed in the air or orthophotos.

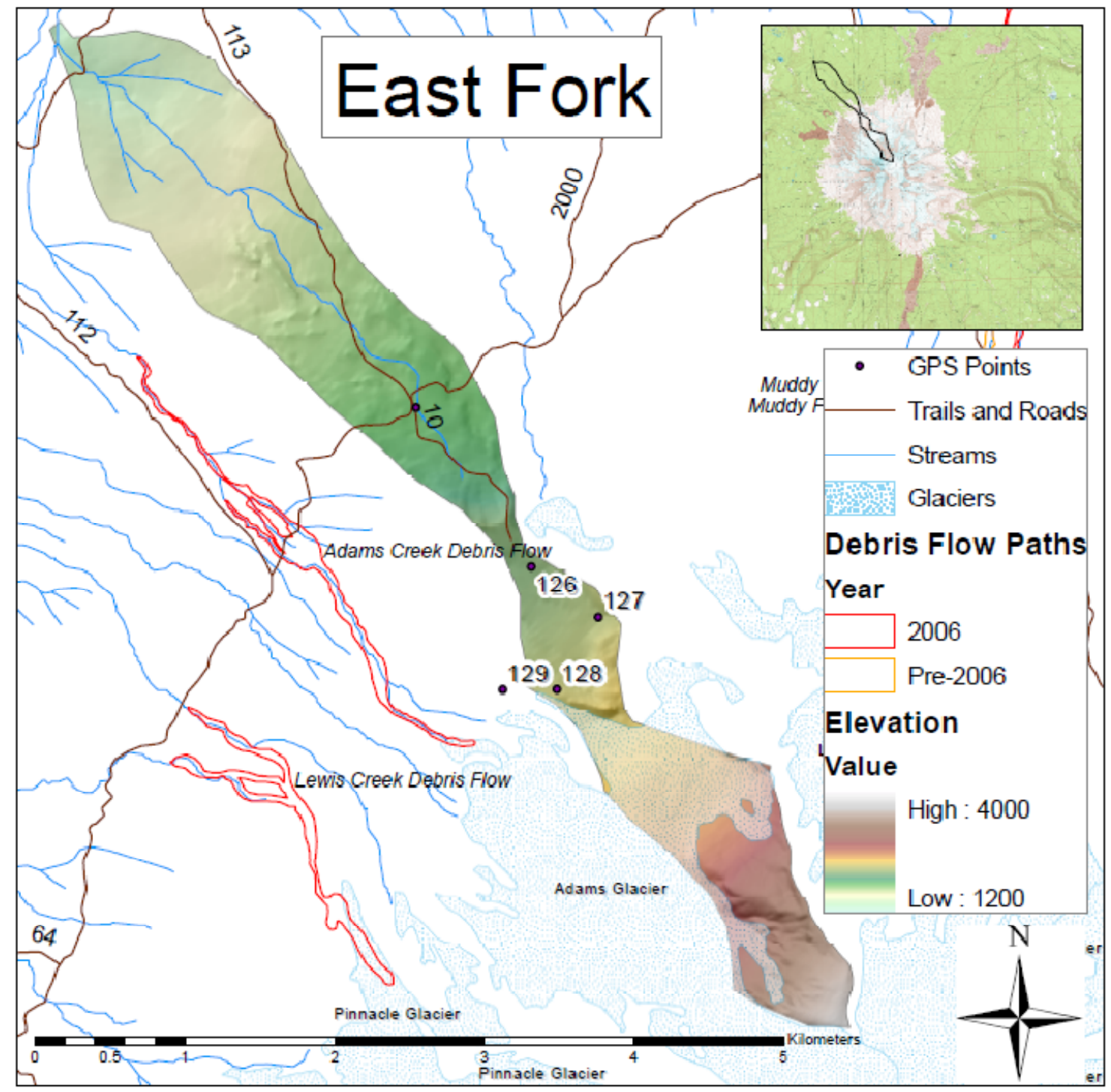

Figure 25: Map of East Fork Drainage. Black numbers are trail and road indicators, black numbers with white halos refer to GPS points. 


\section{Reconnaissance}

Initial reconnaissance was conducted in the summer of 2009. Only one small creek is passed on Trail 9 in the East Fork Drainage. This stream exhibited normal stream activity and erosion. No evidence of incision or debris flow deposit was found.

\section{Initiation Zone}

During the summer of 2010 the upper East Fork Drainage was explored by hiking up Trail 10 from Trail 113. At high elevations scenic meadows were encountered and several small tributary drainages were seen (Figure 26). No debris flow activity or initiation zones were found.

\section{Sample Collection}

Three soil samples for East Fork were taken from GPS point 128. This location was chosen because the elevation was similar to that of other debris flow initiation zones. It was taken in an area geologically mapped as Quaternary Glacial Drift (Qad) (Department of Natural Resources, 2005).

Sieve Results

Samples from East Fork Drainage are presented in Table 9 along with average values. Bulk density was measured at $1.9 \mathrm{~g} / \mathrm{cm}^{3}$, and the sample contained $33 \%$ gravel, $65 \%$ sand and $1 \%$ fines. 
Table 9: East Fork sieve results, sample 128 subsets 1, 2 and 3. See Table 1 for exact size definitions. Bottom row holds the average values.

\begin{tabular}{|c|c|c|c|c|c|c|c|}
\hline \multirow{2}{*}{$\#$} & \multirow{2}{*}{$\begin{array}{c}\text { Bulk Density } \\
\text { (g/cm3) }\end{array}$} & \multirow{2}{*}{ Gravel } & \multirow{2}{*}{ Sand } & \multicolumn{3}{|c|}{ Sand Distribution } & \multirow{2}{*}{$\begin{array}{l}\text { Silt \& } \\
\text { Clay }\end{array}$} \\
\hline & & & & Coarse Sand & Medium Sand & Fine Sand & \\
\hline 1 & 1.8 & 38 & 58 & 42 & 11 & 6 & 2.6 \\
\hline 2 & 1.8 & 32 & 66 & 47 & 10 & 9 & 0.3 \\
\hline 3 & 1.9 & 28 & 70 & 48.9 & 12 & 9 & 1.0 \\
\hline $\bar{x}$ & $1.9 \pm 0$ & $33 \pm 5$ & $65 \pm 6.2$ & $46 \pm 3.6$ & $11 \pm 1.2$ & $8 \pm 1.9$ & $1.3 \pm 1.2$ \\
\hline
\end{tabular}

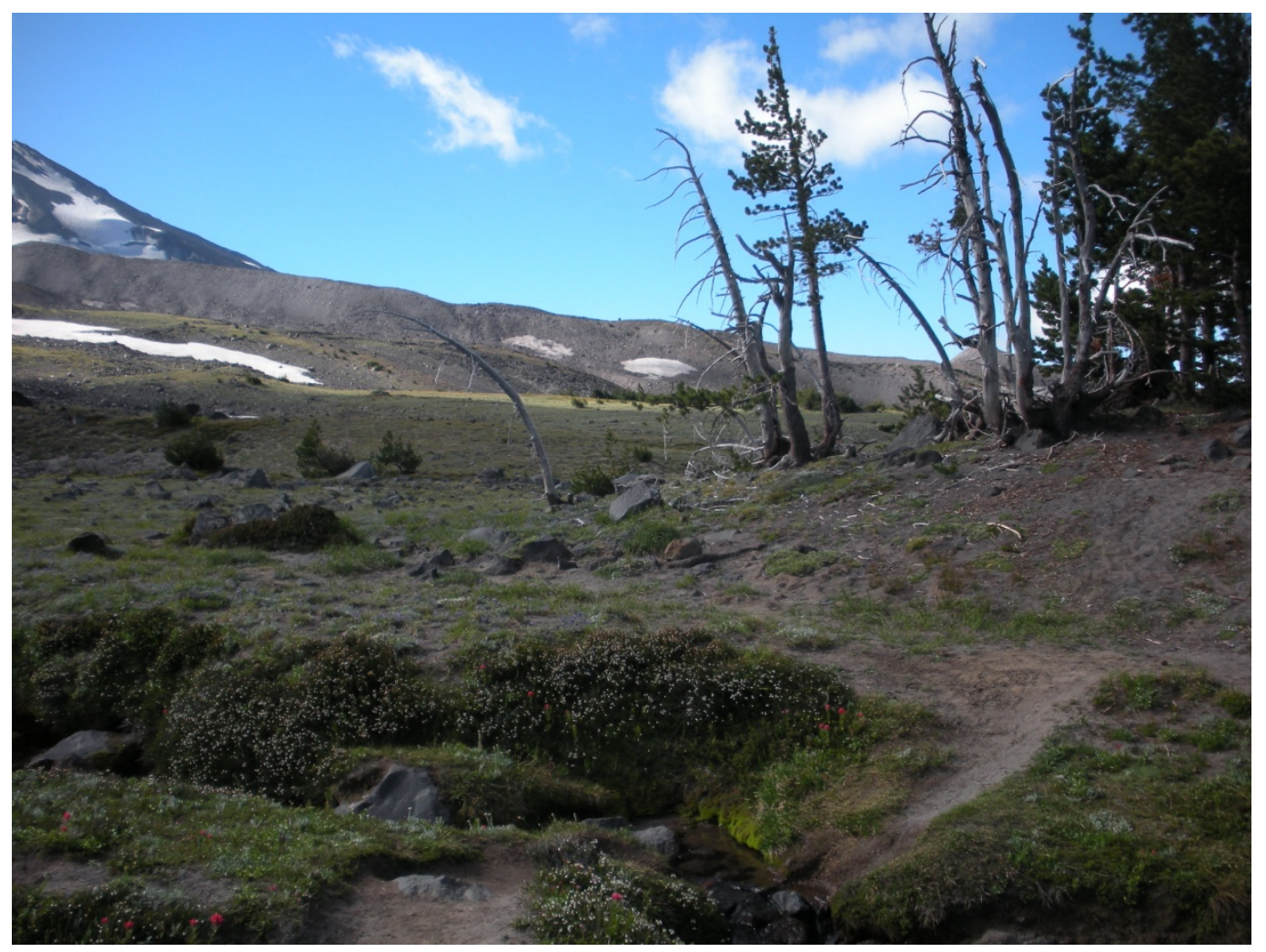

Figure 26: An alpine meadow in the East Fork Drainage at 2,100 m known as "High Camp". Photo taken in September, 2010.

\section{Basin Attributes}

The total East Fork basin area is $6.9 \mathrm{~km}^{2}$, and the upper basin is $3.0 \mathrm{~km}^{2}$. The distance from the stream beginning to the glacier is $1,900 \mathrm{~m}$ and $0.9 \mathrm{~km}^{2}$, or $29 \%$, of the upper basin is covered in glaciers. The stream is not directly connected to the glacier. 
The highest elevation of the basin is 3,600 m, the basin height is $2,250 \mathrm{~m}$, and the basin length is $3,710 \mathrm{~m}$. The gradient of the upper basin is $0.47,6 \%$ of the upper basin is vegetated and $30 \%$ are steep slopes. MRN is calculated as 0.86 , and the average annual precipitation is $2.5 \mathrm{~m}$.

Table 10: East Fork Drainage Basin attributes

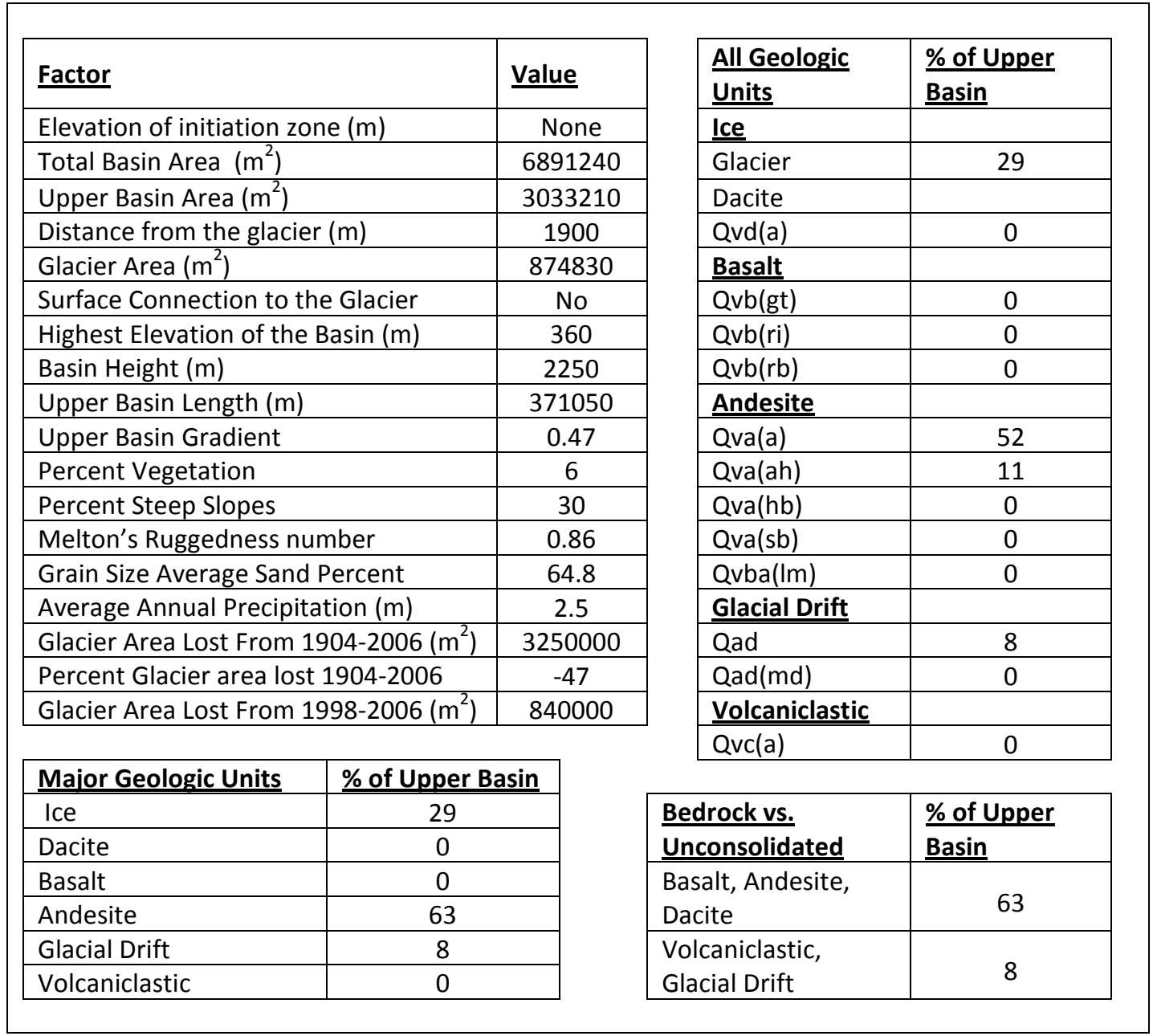




\subsubsection{Gotchen Creek}

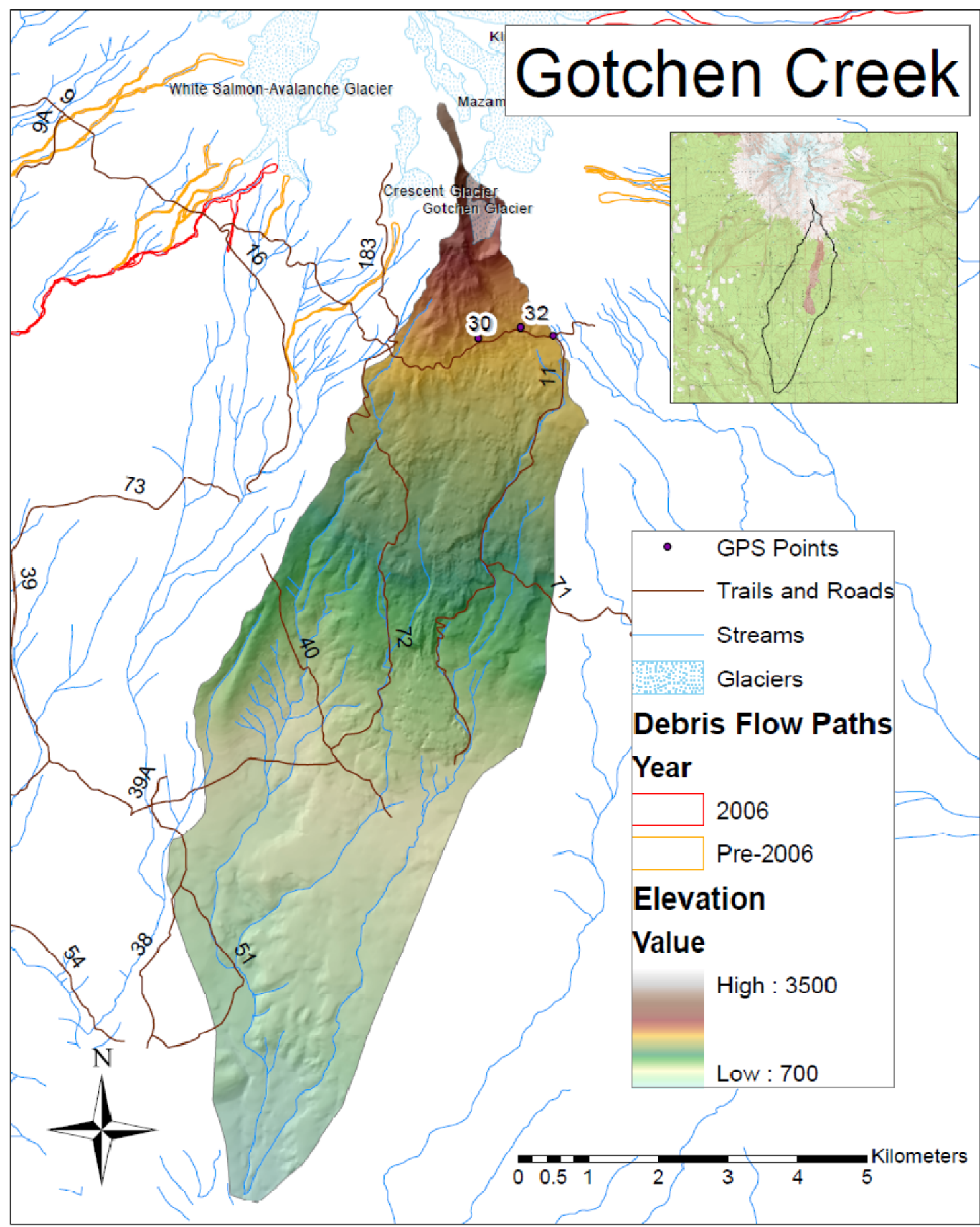

Figure 27: Map of Gotchen Creek Drainage. Black numbers are trail and road indicators, black numbers with white halos refer to GPS points. 
This drainage is accessible from Trail 9 and links the access from the Gifford

Pinchot National Forest to the Yakama Nation Bird Creek access. This drainage is long and spans a wide area in its downstream portion. No debris flow activity was observed for this drainage, and no evidence of past debris flows were observed in the oblique air photos. This portion of the mountain is dry, and most of the stream channels crossed were not flowing on the surface.

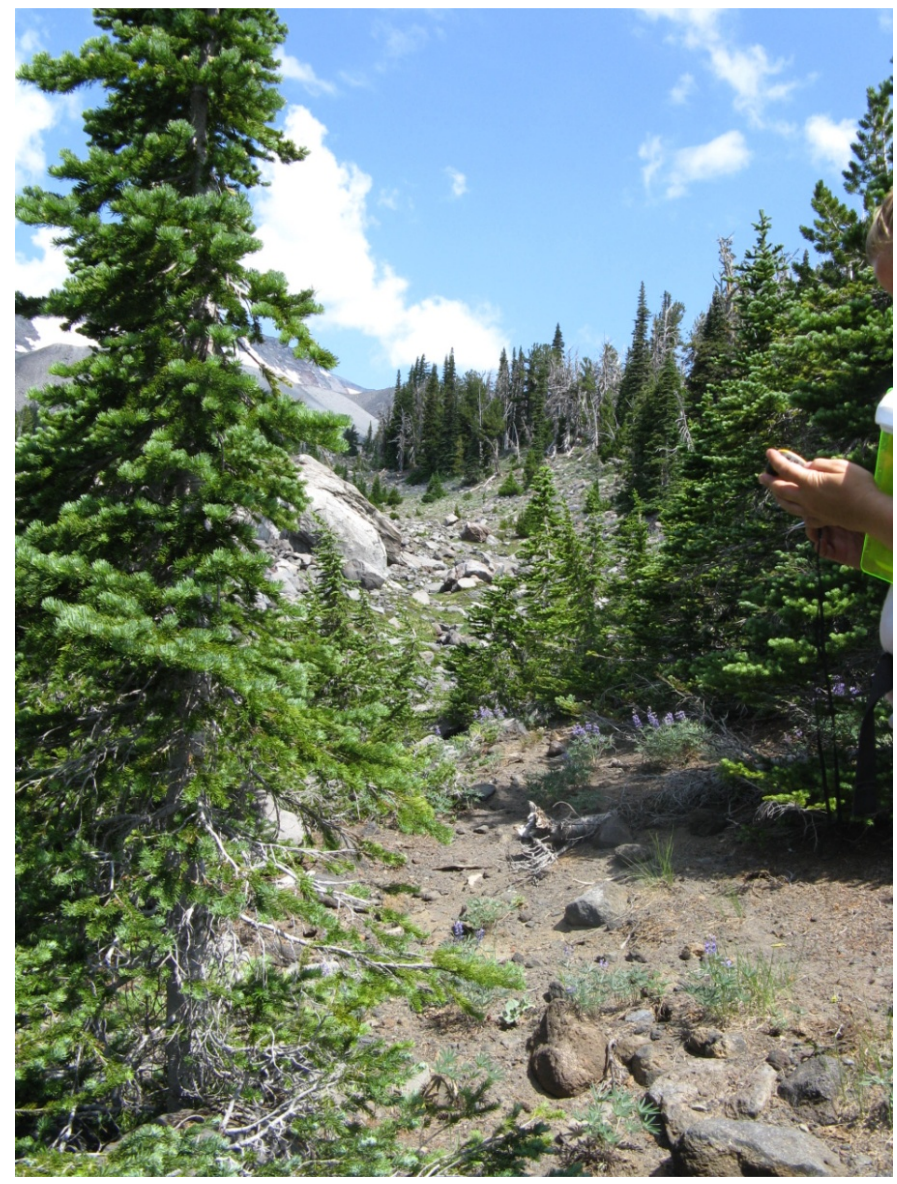

Figure 28: Dry creek in the Gotchen Creek Drainage. Photo taken during the summer of 2009.

\section{Reconnaissance}

Initial reconnaissance was conducted in the summer of 2009. While hiking Trail 9 across the Gotchen Creek Drainage, several dry stream beds were crossed. No evidence 
of recent or past debris flow activity was encountered. Stream beds were highly

vegetated with no boulder deposits, incision or excessive channel erosion (Figure 28).

Initiation Zone, Sample Collection, and Sieve Results

Due to lack of debris flow activity, a limited field season and a large study area, samples were not collected for Gotchen Creek.

Table 11: Gotchen Creek Drainage Basin attributes

\begin{tabular}{|c|c|c|c|c|}
\hline \multicolumn{2}{|l|}{ Factor } & $\underline{\text { Value }}$ & $\begin{array}{l}\text { All Geologic } \\
\text { Units }\end{array}$ & $\begin{array}{l}\text { \% of Upper } \\
\text { Basin }\end{array}$ \\
\hline \multicolumn{2}{|c|}{ Elevation of initiation zone (m) } & None & Ice & \\
\hline \multicolumn{2}{|l|}{ Total Basin Area $\left(\mathrm{m}^{2}\right)$} & 42791960 & $\overline{\text { Glacier }}$ & 9 \\
\hline \multicolumn{2}{|l|}{ Upper Basin Area $\left(\mathrm{m}^{2}\right)$} & 3063110 & Dacite & \\
\hline \multicolumn{2}{|c|}{ Distance from the glacier $(\mathrm{m})$} & 1100 & Qvd(a) & 0 \\
\hline \multicolumn{2}{|c|}{ Glacier Area $\left(\mathrm{m}^{2}\right)$} & 258120 & Basalt & \\
\hline \multicolumn{2}{|c|}{ Surface Connection to the Glacier } & No & Qvb(gt) & 0 \\
\hline \multicolumn{2}{|c|}{ Highest Elevation of the Basin (m) } & 2870 & Qvb(ri) & 0 \\
\hline \multicolumn{2}{|l|}{ Basin Height (m) } & 2310 & $\mathrm{Qvb}(\mathrm{rb})$ & 0 \\
\hline \multicolumn{2}{|l|}{ Upper Basin Length (m) } & 4040 & Andesite & \\
\hline \multicolumn{2}{|l|}{ Upper Basin Gradient } & 0.26 & Qva(a) & 23 \\
\hline \multicolumn{2}{|l|}{ Percent Vegetation } & 9 & Qva(ah) & 12 \\
\hline \multicolumn{2}{|l|}{ Percent Steep Slopes } & 7 & Qva(hb) & 0 \\
\hline \multicolumn{2}{|c|}{ Melton's Ruggedness number } & 0.35 & Qva(sb) & 36 \\
\hline \multicolumn{2}{|c|}{ Grain Size Average Sand Percent } & None & Qvba(Im) & 0 \\
\hline \multicolumn{2}{|c|}{ Average Annual Precipitation (m) } & 2.2 & Glacial Drift & \\
\hline \multicolumn{2}{|c|}{ Glacier Area Lost From 1904-2006 (m²) } & 620000 & Qad & 21 \\
\hline \multicolumn{2}{|c|}{ Percent Glacier area lost 1904-2006 } & -78 & Qad(md) & 0 \\
\hline \multicolumn{2}{|c|}{ Glacier Area Lost From 1998-2006 $\left(\mathrm{m}^{2}\right)$} & 190000 & Volcaniclastic & \\
\hline \multirow{2}{*}{\multicolumn{3}{|c|}{\begin{tabular}{|l|l|}
\multicolumn{3}{|l|}{ Maior Geologic Units } & $\%$ of Upper Basin \\
\end{tabular}}} & Qvc(a) & 0 \\
\hline & & $\operatorname{asin}$ & & \\
\hline Ice & \multicolumn{2}{|c|}{9} & \multirow{2}{*}{$\begin{array}{l}\text { Bedrock vs. } \\
\text { Unconsolidated }\end{array}$} & \% of Upper \\
\hline Dacite & \multicolumn{2}{|l|}{0} & & Basin \\
\hline Basalt & \multicolumn{2}{|l|}{0} & \multirow{2}{*}{$\begin{array}{l}\text { Basalt, Andesite, } \\
\text { Dacite }\end{array}$} & \multirow{2}{*}{71} \\
\hline Andesite & \multicolumn{2}{|l|}{71} & & \\
\hline Glacial Drift & \multicolumn{2}{|l|}{21} & \multirow{2}{*}{$\begin{array}{l}\text { Volcaniclastic, } \\
\text { Glacial Drift }\end{array}$} & \multirow[b]{2}{*}{21} \\
\hline Volcaniclastic & 0 & & & \\
\hline
\end{tabular}




\section{Basin Attributes}

The total Gotchen Creek Basin area is $42.8 \mathrm{~km}^{2}$, and the upper basin is $3.1 \mathrm{~km}^{2}$. The distance from the stream beginning to the glacier is $1,100 \mathrm{~m}$ and $.3 \mathrm{~km}^{2}$, or $9 \%$, of the upper basin is covered in glaciers. The stream is not directly connected to the glacier. The highest elevation of the basin is $2,870 \mathrm{~m}$, the basin height is $2,310 \mathrm{~m}$, and the basin length is $4,040 \mathrm{~m}$. The gradient of the upper basin is $0.26,9 \%$ of the upper basin is vegetated and $7 \%$ are steep slopes. MRN is calculated as 0.35 , and the average annual precipitation is $2.2 \mathrm{~m}$.

\subsubsection{Hellroaring Creek}

Hellroaring Creek is located on the southeast side of Mt. Adams (Figure 29). It is a popular destination for hikers, offering exiting views of the mountain and the sweeping canyon of the drainage floor. This drainage showed debris flow activity in several channels in the upper basin. Incision and sidewall collapse appeared recent, but orthophoto analysis showed these most likely occurred before the November 2006 storm.

\section{Reconnaissance}

Initial reconnaissance was conducted in the summer of 2010. From the Hellroaring Canyon overlook, incision and eroded channel side walls were visible (Figure 30). This debris flow activity was hard to date based on the lack of vegetation and access points to the drainage. 
Orthophoto analysis indicated some change between the pre-storm 2006 photo and the 2009 photo, but not enough to suggest significant debris flow activity since 2006. More prominent debris flow characteristics, such as deeper incised channels in several locations in the 2006 photo supported pre-2006 debris flow activity. These facts lead to the conclusion that this drainage has experienced debris flows in the past but not during the 2006 storm.

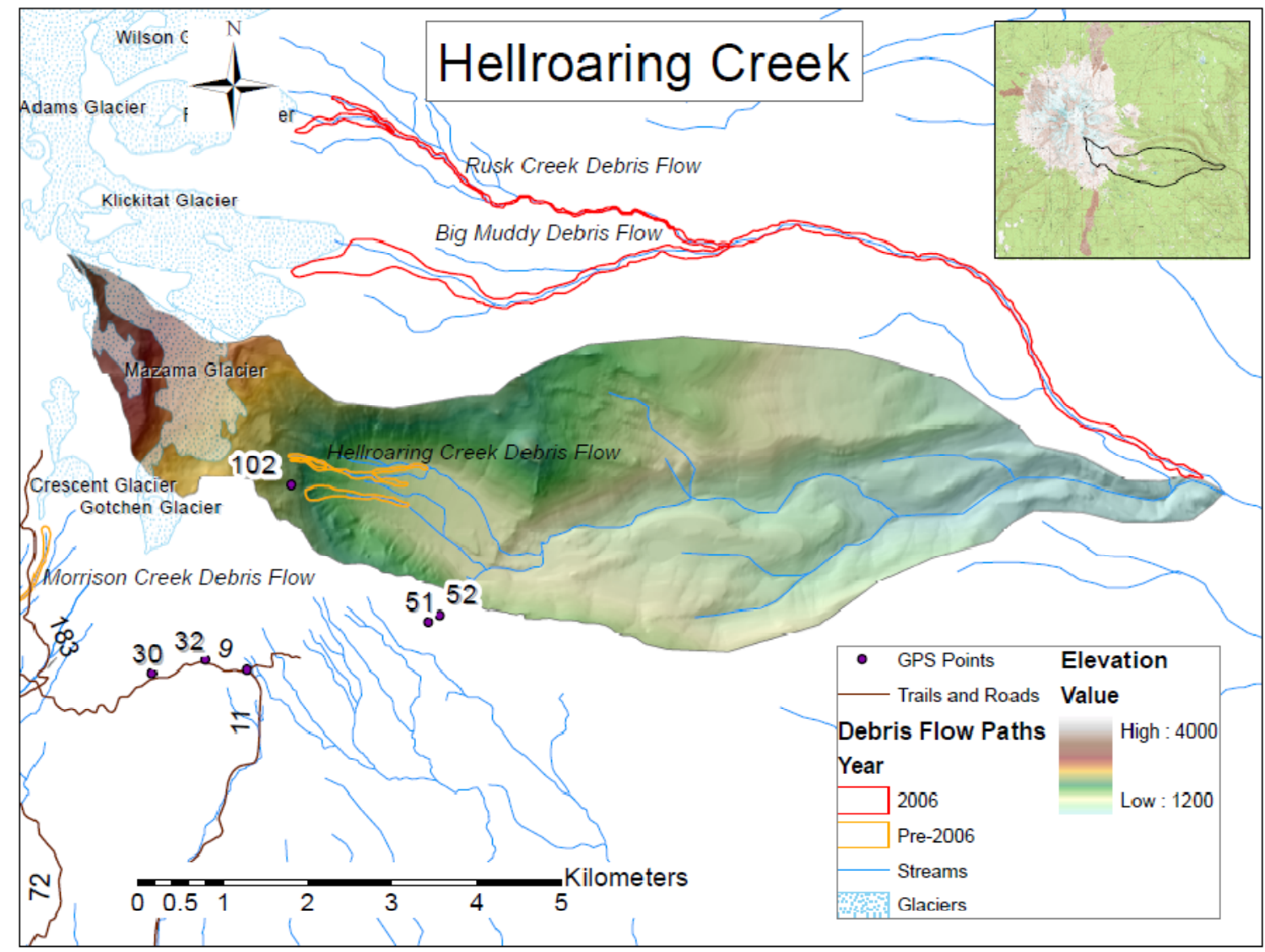

Figure 29: Map of Hellroaring Creek Drainage. Black numbers are trail and road indicators, black numbers with white halos refer to GPS points.

\section{Initiation Zone}

During the summer of 2010 the upper Hellroaring Creek Drainage was explored by hiking a ridge between the Bird Creek and Hellroaring Creek drainages. Several fresh 
looking collapsed sidewalls in the upper drainage area were visible; it was not possible to tell which could have been the initiation zone for the past debris flow activity due to snow cover. There are several upper basin channels with collapses that coalesce in the lower basin, suggesting the possibility of previous debris flows being headless debris flows.

Oblique air photos were taken during the summer of 2010 of the Hellroaring Creek Debris Flow Initiation Area (Figure 31). Here, the coalescence of eroded channels is visible as well as incision in the channel; however, an exact initiation zone or mechanism is still not visible.

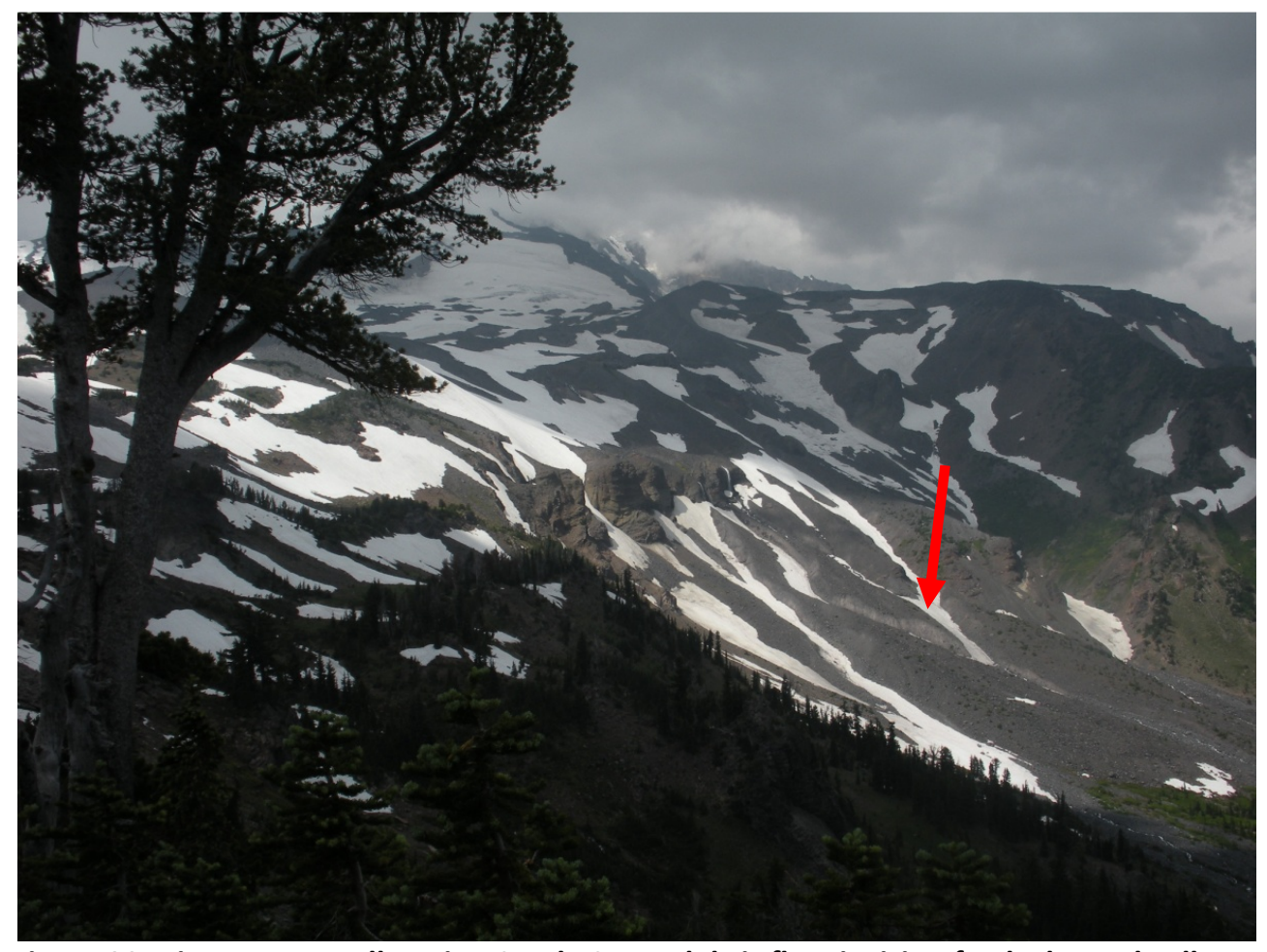

Figure 30: View across Hellroaring Creek. Some debris flow incision fresh channel collapse are visible in several locations. Red Arrow points out most obvious area. Photo taken during the summer of 2010. 


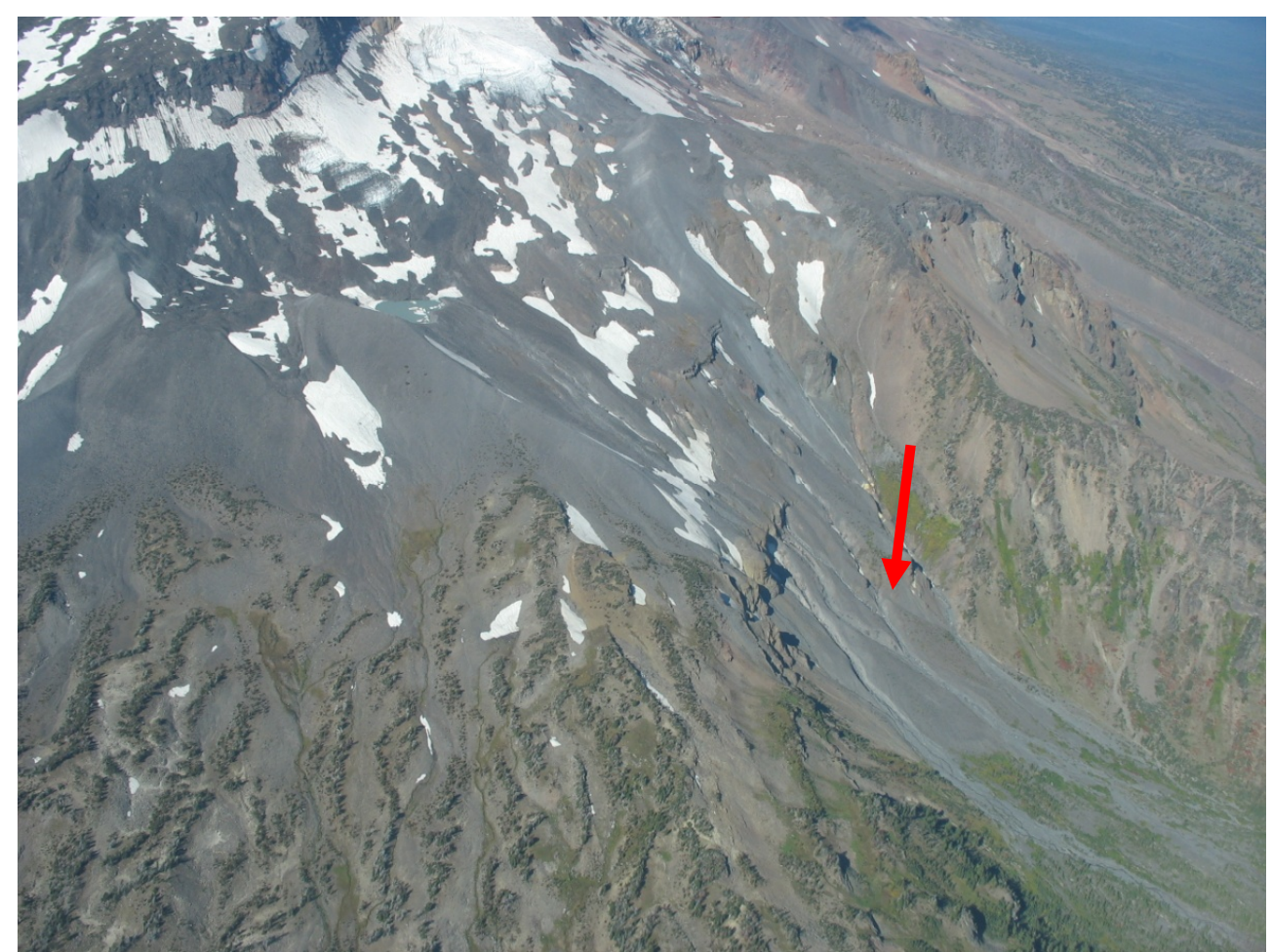

Figure 31: Oblique air photo of Hellroaring Creek. Red arrow points out incision seen in Figure 30. Channels are visible in the lower right of the photo. Photo taken September $30^{\text {th }}, 2010$.

\section{Sample Collection}

Three soil samples for Hellroaring Creek were taken from GPS point 102. This

location was directly upstream from one of the possible initiation zone areas and is mapped as Quaternary Andesite Flows (Qva) (Department of Natural Resources, 2005).

Table 12: Hellroaring Creek sieve results, sample 102 subsets 1, 2 and 3. See Table 1 for exact size definitions. Bottom row holds the average values.

\begin{tabular}{|c|c|c|c|c|c|c|c|}
\hline \multirow{2}{*}{$\#$} & \multirow{2}{*}{$\begin{array}{c}\text { Bulk Density } \\
\text { (g/cm3) }\end{array}$} & Gravel & Sand & \multicolumn{3}{|c|}{ Sand Distribution } & \multirow{2}{*}{$\begin{array}{c}\text { Silt \& } \\
\text { Clay }\end{array}$} \\
\cline { 5 - 8 } & & & & Coarse Sand & Medium Sand & Fine Sand & 5 \\
\hline 1 & 1.7 & 26 & 72 & 51 & 15 & 5 & 1.6 \\
2 & 1.8 & 20 & 77 & 52 & 16 & 10 & 2.8 \\
3 & 1.8 & 28 & 67 & 42 & 14 & 11 & 4.5 \\
\hline $\bar{x}$ & $1.8 \pm 0$ & $25 \pm 4$ & $72 \pm 5.1$ & $48 \pm 5.2$ & $15 \pm 1.2$ & $9 \pm 3.2$ & $3.0 \pm 1.4$ \\
\hline
\end{tabular}


Sieve Results

Samples from Hellroaring Creek Drainage are presented in Table 12 along with average values. Bulk density was measured at $1.8 \mathrm{~g} / \mathrm{cm}^{3}$, and the sample contained $25 \%$ gravel, $72 \%$ sand and $3 \%$ fines.

Table 13: Hellroaring Creek Drainage basin attributes.

\begin{tabular}{|c|c|}
\hline Factor & $\underline{\text { Value }}$ \\
\hline Elevation of initiation zone $(\mathrm{m})$ & None \\
\hline Total Basin Area $\left(\mathrm{m}^{2}\right)$ & 25953330 \\
\hline Upper Basin Area $\left(\mathrm{m}^{2}\right)$ & 7594790 \\
\hline Distance from the glacier $(\mathrm{m})$ & 0 \\
\hline Glacier Area $\left(\mathrm{m}^{2}\right)$ & 1655030 \\
\hline Surface Connection to the Glacier & Yes \\
\hline Highest Elevation of the Basin (m) & 3370 \\
\hline Basin Height (m) & 2490 \\
\hline Upper Basin Length (m) & 6330 \\
\hline Upper Basin Gradient & 0.29 \\
\hline Percent Vegetation & 29 \\
\hline Percent Steep Slopes & 16 \\
\hline Melton's Ruggedness number & 0.49 \\
\hline Grain Size Average Sand Percent & 72 \\
\hline Average Annual Precipitation (m) & 1.8 \\
\hline Glacier Area Lost From 1904-2006 $\left(\mathrm{m}^{2}\right)$ & 910000 \\
\hline Percent Glacier area lost 1904-2006 & -62 \\
\hline Glacier Area Lost From 1998-2006 (m²) & 345000 \\
\hline
\end{tabular}

\begin{tabular}{|l|c|}
\hline Major Geologic Units & \% of Upper Basin \\
\hline Ice & 22 \\
\hline Dacite & 1 \\
\hline Basalt & 0 \\
\hline Andesite & 38 \\
\hline Glacial Drift & 39 \\
\hline Volcaniclastic & 0 \\
\hline
\end{tabular}

\begin{tabular}{|l|c|}
\hline $\begin{array}{l}\text { All Geologic } \\
\text { Units }\end{array}$ & $\begin{array}{l}\text { \% of Upper } \\
\text { Basin }\end{array}$ \\
\hline$\underline{\text { Ice }}$ & \\
\hline Glacier & 22 \\
\hline Dacite & 1 \\
\hline Qvd(a) & \\
\hline Basalt & 0 \\
\hline Qvb(gt) & 0 \\
\hline Qvb(ri) & 0 \\
\hline Qvb(rb) & \\
\hline Andesite & 11 \\
\hline Qva(a) & 0 \\
\hline Qva(ah) & 26 \\
\hline Qva(hb) & 0 \\
\hline Qva(sb) & 1 \\
\hline Qvba(Im) & \\
\hline Glacial Drift & 39 \\
\hline Qad & 0 \\
\hline Qad(md) & \\
\hline Volcaniclastic & \\
\hline Qvc(a) & \\
\hline
\end{tabular}

\begin{tabular}{|l|c|}
\hline $\begin{array}{l}\text { Bedrock vs. } \\
\text { Unconsolidated }\end{array}$ & $\begin{array}{l}\text { \% of Upper } \\
\text { Basin }\end{array}$ \\
\hline $\begin{array}{l}\text { Basalt, Andesite, } \\
\text { Dacite }\end{array}$ & 39 \\
\hline $\begin{array}{l}\text { Volcaniclastic, } \\
\text { Glacial Drift }\end{array}$ & 39 \\
\hline
\end{tabular}

\section{Basin Attributes}

The total Hellroaring Creek Basin area is $26.0 \mathrm{~km}^{2}$, and the upper basin is 7.6 $\mathrm{km}^{2}$. The distance from the stream beginning to the glacier is zero meters and $1.7 \mathrm{~km}^{2}$, or $22 \%$, of the upper basin is covered in glaciers. The stream is directly connected to the 
glacier. The highest elevation of the basin is $3,370 \mathrm{~m}$, the basin height is $2,490 \mathrm{~m}$, and the basin length is $6,330 \mathrm{~m}$. The gradient of the upper basin is $0.29,29 \%$ of the upper basin is vegetated and $16 \%$ are steep slopes. MRN is calculated as 0.49 , and the average annual precipitation is $1.8 \mathrm{~m}$ (Table 13).

\subsubsection{Horseshoe Creek}

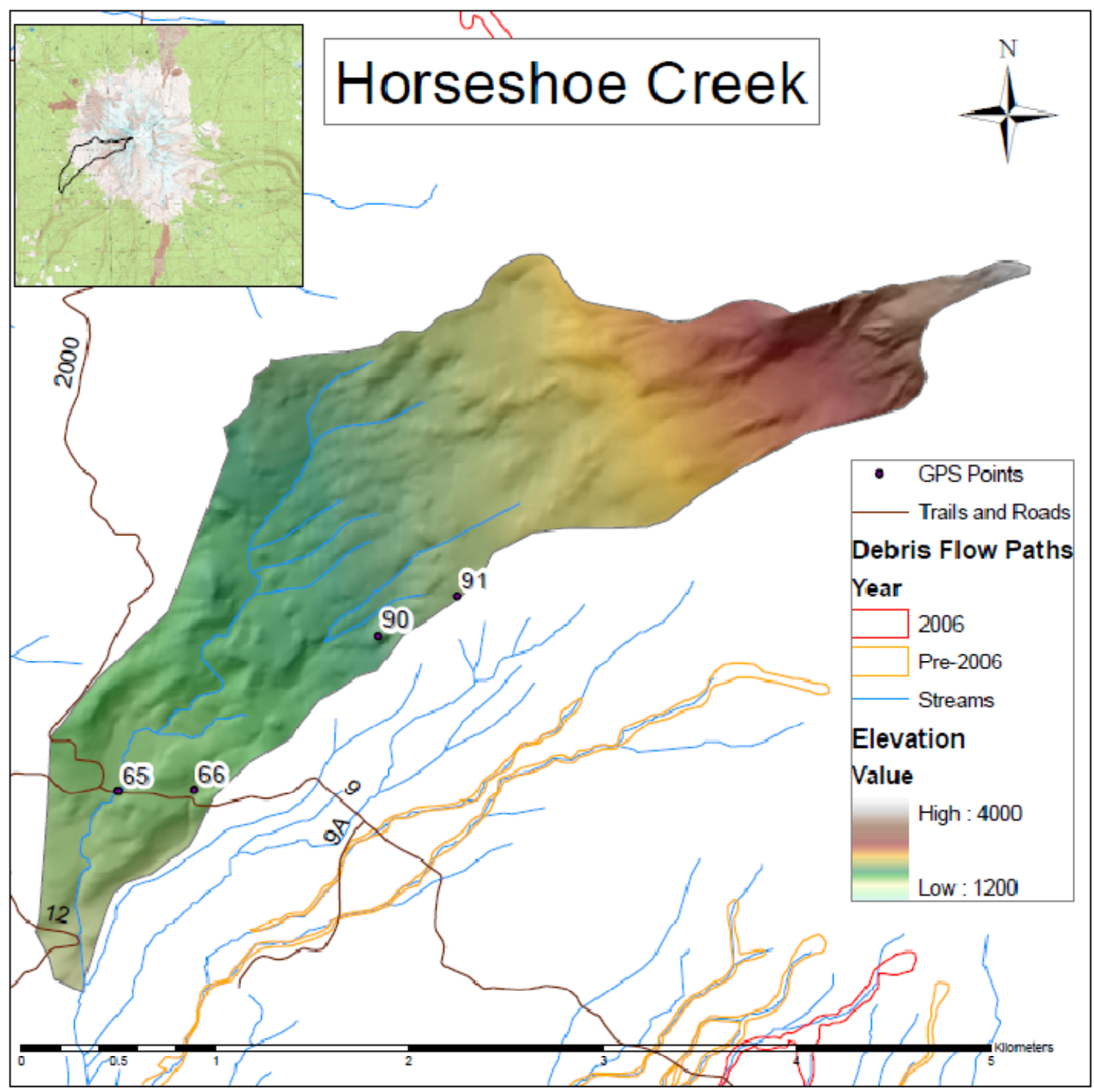

Figure 32: Map of Horseshoe Creek Drainage. Black numbers are trail and road indicators, black numbers with white halos refer to GPS points. 
Horseshoe Creek is located on the southwest side of Mt. Adams (Figure 32). This drainage is fairly secluded but is accessible from Trails 12 and 9. No debris flow activity was observed for this drainage, and no evidence of past debris flows was observed in the oblique air photos or orthophotos.

\section{Reconnaissance}

Initial reconnaissance was conducted in the summer of 2009. Following Trail 9 in Horseshoe Creek Drainage two small creeks were passed. Normal stream activity and erosion appeared to be taking place. No evidence of incision or debris flow deposit was found (Figure 33).

\section{Initiation Zone}

During the summer of 2010 the upper Horseshoe Creek Drainage was explored by hiking a ridge between the Horseshoe Creek and Cascade Creek drainages. At higher elevations still no debris flow activity was visible (Figure 34).

\section{Sample Collection}

Three soil samples for Horseshoe Creek were taken from GPS point 91. This location was chosen because the elevation was similar to that of other debris flow initiation zones. It was taken in an area geologically mapped as Quaternary Glacial Drift (Qad) (Department of Natural Resources, 2005). 
Sieve Results

Samples from Horseshoe Creek Drainage are presented in Table 14 along with average values. Bulk density was measured at $1.7 \mathrm{~g} / \mathrm{cm}^{3}$, and the sample contained $24 \%$ gravel, $71 \%$ sand and $4 \%$ fines.

Table 14: Horseshoe Creek sieve results, sample 91 subsets 1, 2 and 3. See Table 1 for exact size definitions. Bottom row holds the average values.

\begin{tabular}{|c|c|c|c|c|c|c|c|}
\hline \multirow{2}{*}{$\#$} & \multirow{2}{*}{$\begin{array}{c}\text { Bulk Density } \\
(\mathrm{g} / \mathrm{cm} 3)\end{array}$} & Gravel & Sand & \multicolumn{3}{|c|}{ Sand Distribution } & \multirow{2}{*}{$\begin{array}{c}\text { Silt \& } \\
\text { Clay }\end{array}$} \\
\cline { 5 - 7 } & & & & Coarse Sand & Medium Sand & Fine Sand & \\
\hline 1 & 1.7 & 29 & 70 & 54 & 16 & 1 & 0.4 \\
2 & 1.7 & 20 & 69 & 47 & 11 & 12 & 9.1 \\
3 & 1.7 & 24 & 75 & 54 & 16 & 4 & 0.9 \\
\hline$x$ & $1.7 \pm 0$ & $24 \pm 4.6$ & $71 \pm 2.9$ & $52 \pm 4.2$ & $14 \pm 3$ & $6 \pm 5.4$ & $4 \pm 4.9$ \\
\hline
\end{tabular}

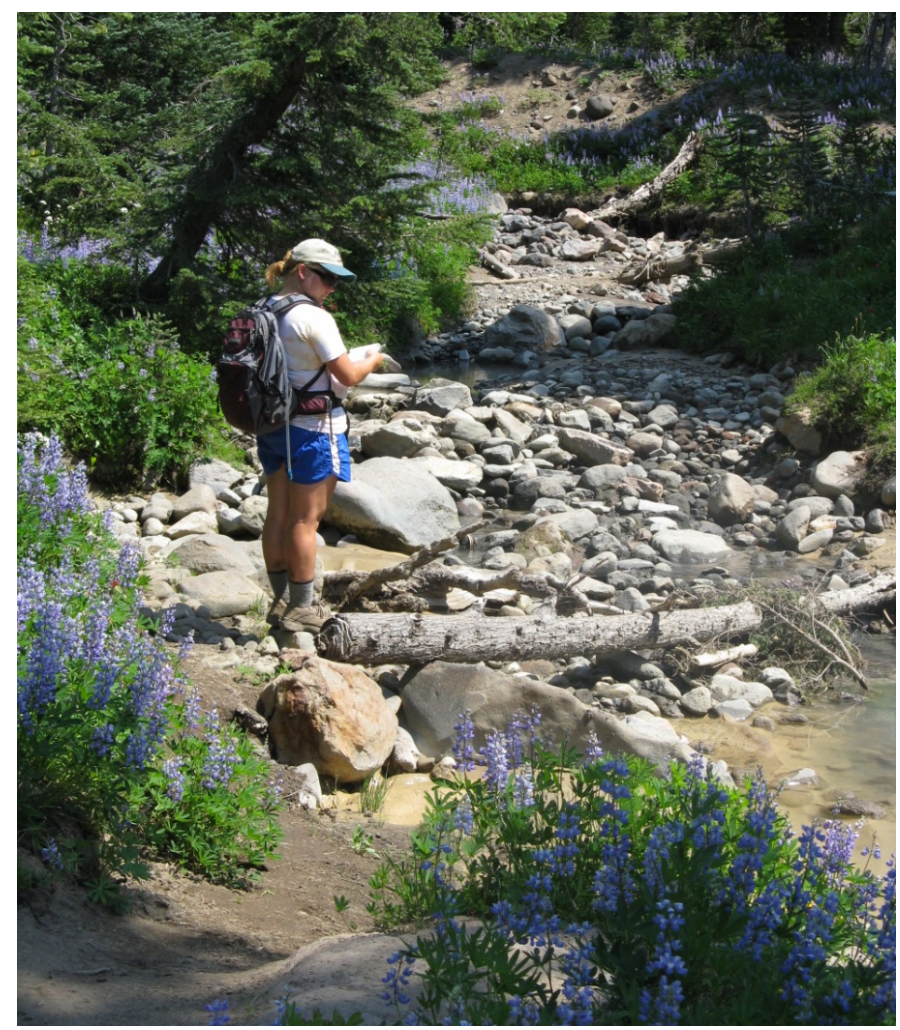

Figure 33: Stream Crossing in the lower Horseshoe Creek Drainage. Photo taken during the summer of 2009. 


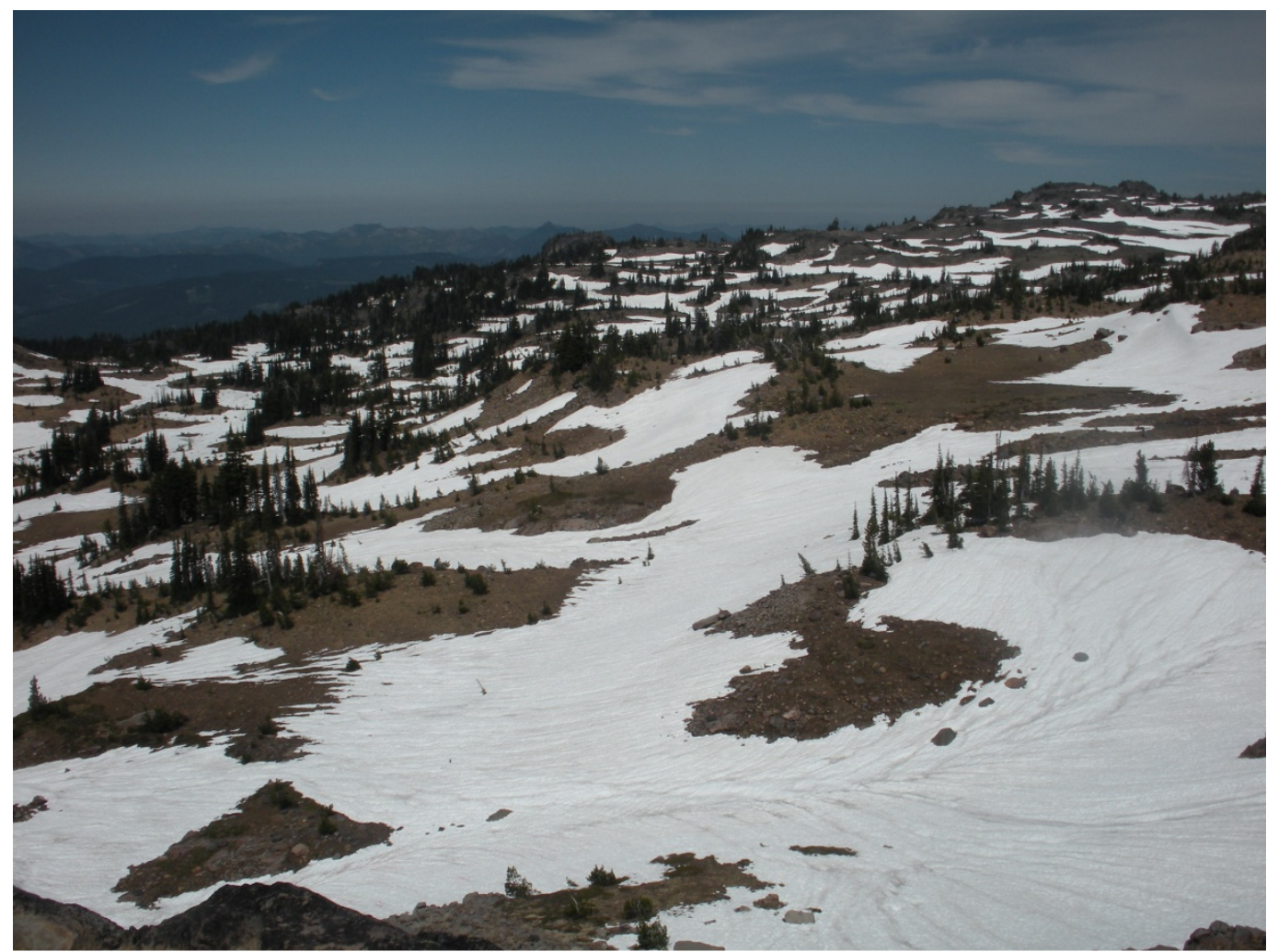

Figure 34: Upper Horseshoe Creek Drainage looking to the northwest. Photo taken during the summer of 2010.

\section{Basin Attributes}

The total Horseshoe Creek basin area is $6.6 \mathrm{~km}^{2}$, and the upper basin is $4.8 \mathrm{~km}^{2}$.

The distance from the stream beginning to the glacier is $1,380 \mathrm{~m}$ and $0.3 \mathrm{~km}^{2}$, or $6 \%$, of the upper basin is covered in glaciers. The stream is not directly connected to the glacier. The highest elevation of the basin is $3,680 \mathrm{~m}$, the basin height is $2,050 \mathrm{~m}$, and the basin length is $4,960 \mathrm{~m}$. The gradient of the upper basin is $0.36,0 \%$ of the upper basin is vegetated, and $8 \%$ are steep slopes. MRN is calculated as 0.80 , and the average annual precipitation is $3.3 \mathrm{~m}$. 
Table 15: Horseshoe Creek Drainage

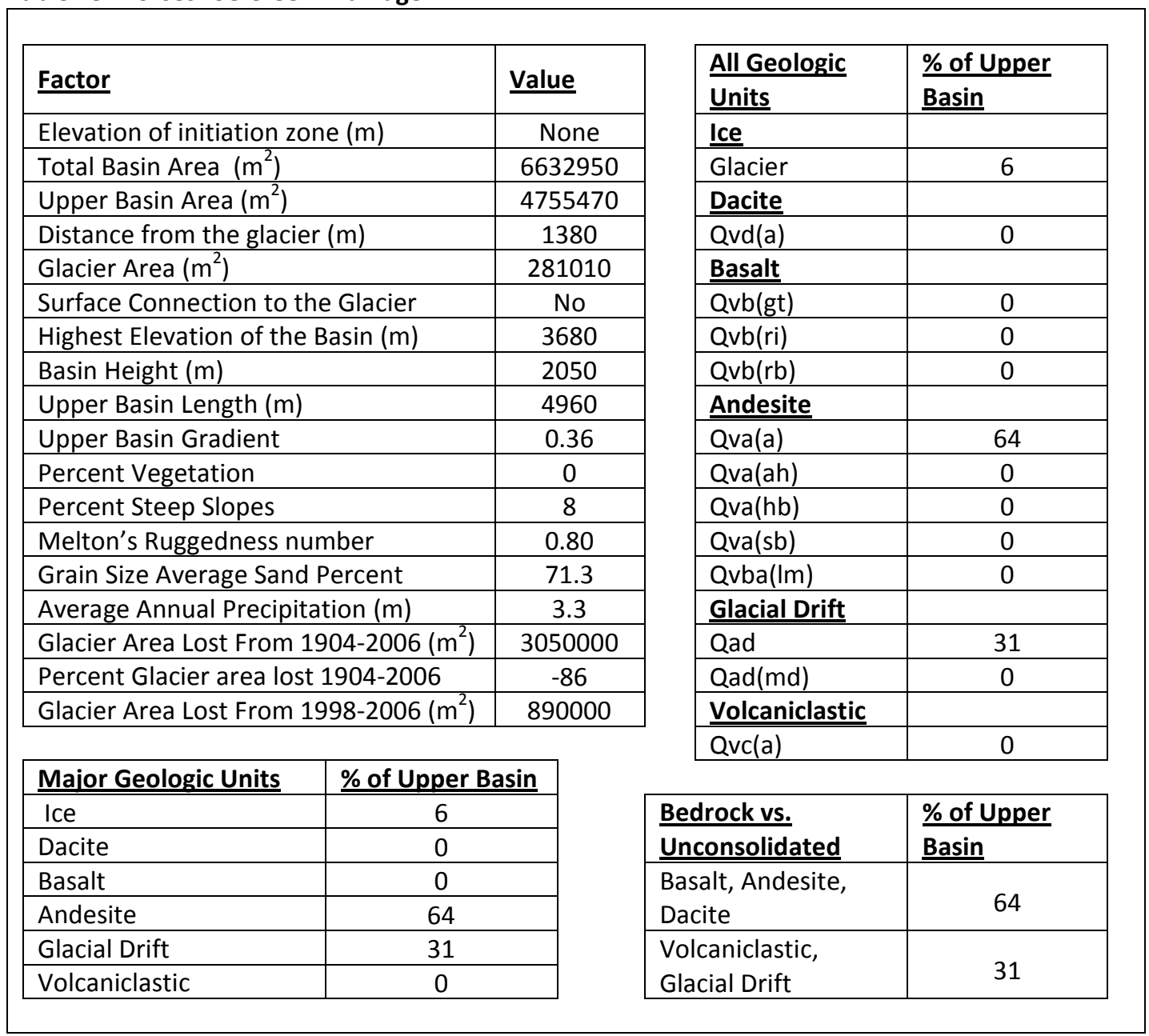

\subsubsection{Killen Creek}

Killen Creek is located on the northwest side of Mt. Adams (Figure 35). This

drainage is accessible from Trails 113 and 9. This drainage is a popular area for horse

riders and other visitors using pack animals. No debris flow activity was observed for this drainage, and no evidence of past debris flows was observed in the oblique air photos or orthophotos. 


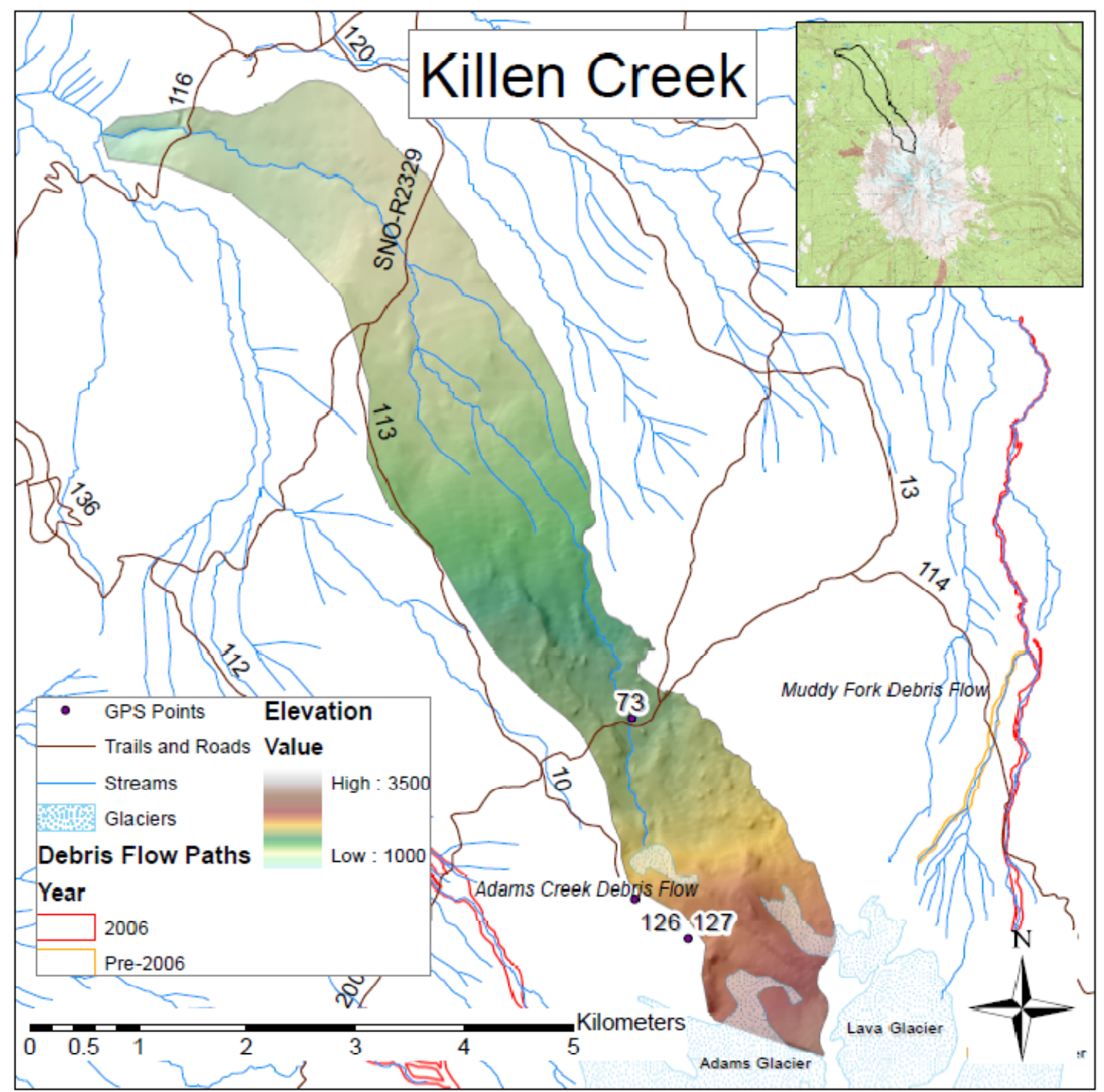

Figure 35: Map of Killen Creek Drainage. Black numbers are trail and road indicators, black numbers with white halos refer to GPS points.

Reconnaissance

Initial reconnaissance was conducted in the summer of 2009. Following Trail 9 in the Killen Creek Drainage a small creek was passed. Normal stream activity and erosion appeared to be taking place. No evidence of incision or debris flow deposit was found. 


\section{Initiation Zone}

During the summer of 2010 the upper Killen Creek Drainage was explored by hiking up Trail 10 from Trail 113. At high elevations scenic meadows were encountered and several small tributary drainages were seen (Figure 36). No debris flow activity or initiation zones were found.

\section{Sample Collection}

Three soil samples for Killen Creek were taken from GPS point 127. This location was chosen because the elevation was similar to that of other debris flow initiation zones. It was taken in an area geologically mapped as Quaternary Andesite Flows (Qva) (Department of Natural Resources, 2006).

\section{Sieve Results}

Samples from Killen Creek Drainage are presented in Table 16 below along with average values. Bulk density was measured at $1.5 \mathrm{~g} / \mathrm{cm}^{3}$, and the sample contained $37 \%$ gravel, $62 \%$ sand and $1 \%$ fines.

Table 16: Killen Creek sieve results, sample 127 subsets 1, 2 and 3. See Table 1 for exact size definitions. Bottom row holds the average values.

\begin{tabular}{|c|c|c|c|c|c|c|c|}
\hline \multirow{2}{*}{$\#$} & \multirow{2}{*}{$\begin{array}{c}\text { Bulk Density } \\
(\mathrm{g} / \mathrm{cm} 3)\end{array}$} & Gravel & Sand & \multicolumn{3}{|c|}{ Sand Distribution } & \multirow{2}{*}{$\begin{array}{c}\text { Silt \& } \\
\text { Clay }\end{array}$} \\
\cline { 5 - 8 } & 1.5 & 36 & 64 & 45 & 16 & 2 & 0.3 \\
\hline 1 & 1.5 & 41 & 56 & 42 & 10 & 5 & 1.5 \\
3 & 1.4 & 34 & 65 & 46 & 12 & 6 & 1.0 \\
\hline $\bar{x}$ & $1.5 \pm 0$ & $37 \pm 3.7$ & $61 \pm 4.2$ & $44 \pm 2.3$ & $13 \pm 3.4$ & $5 \pm 2.1$ & $0.9 \pm .6$ \\
\hline
\end{tabular}




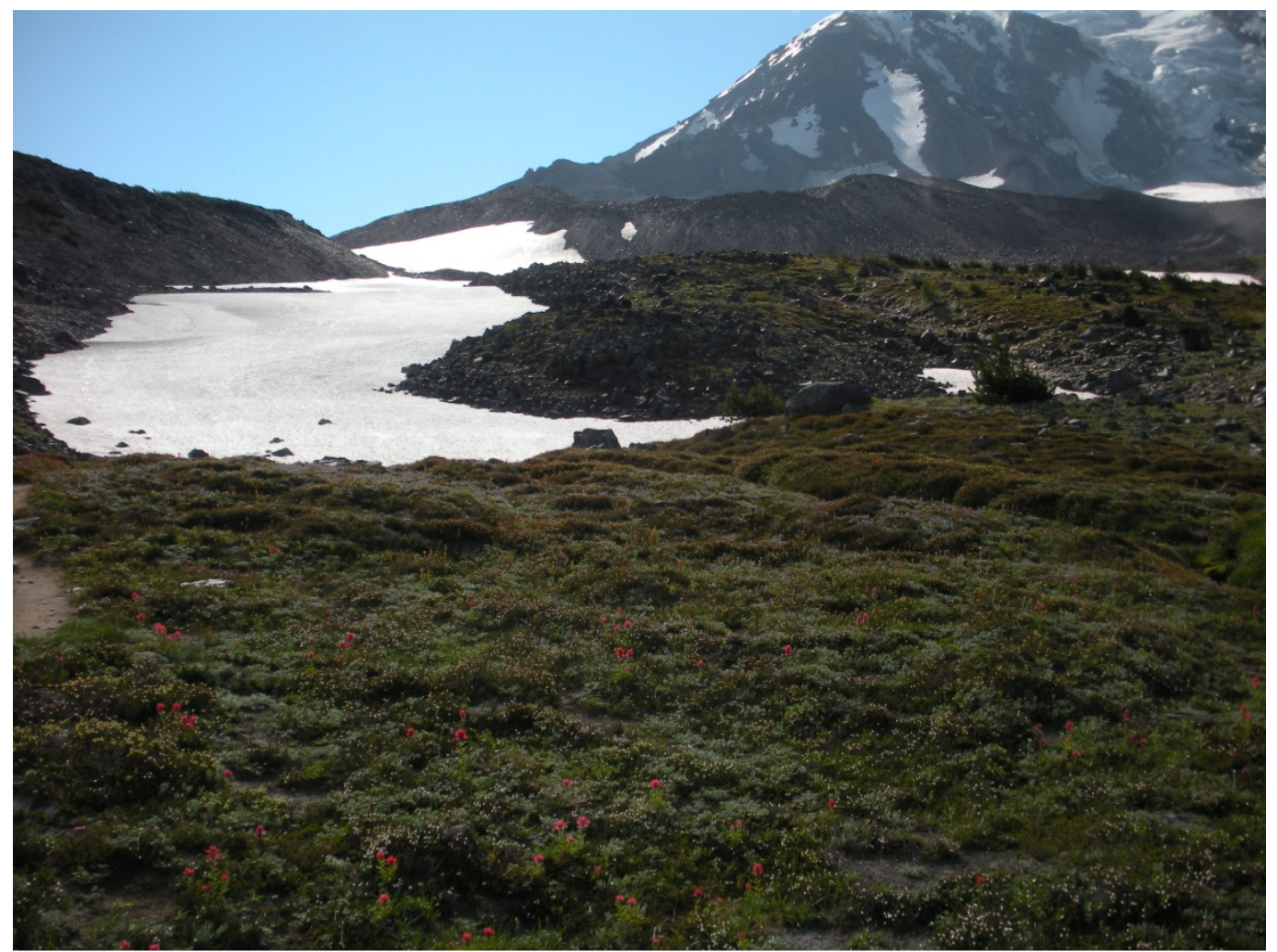

Figure 36: Upper Killen Creek Drainage. Photo taken during the summer of 2010.

\section{Basin Attributes}

The total Killen Creek Basin area is $13.6 \mathrm{~km}^{2}$, and the upper basin is $3.7 \mathrm{~km}^{2}$. The distance from the stream beginning to the glacier is $50 \mathrm{~m}$ and $0.4 \mathrm{~km}^{2}$, or $11 \%$, of the upper basin is covered in glaciers. The stream is not directly connected to the glacier. The highest elevation of the basin is $2,670 \mathrm{~m}$, the basin height is $1,590 \mathrm{~m}$, and the basin length is $3,720 \mathrm{~m}$. The gradient of the upper basin is $0.24,18 \%$ of the upper basin is vegetated and $3 \%$ are steep slopes. MRN is calculated as 0.43 , and the average annual precipitation is $2.4 \mathrm{~m}$. 
Table 17: Killen Creek Drainage Basin attributes

\begin{tabular}{|c|c|c|c|c|}
\hline \multicolumn{2}{|l|}{ Factor } & $\underline{\text { Value }}$ & $\begin{array}{l}\text { All Geologic } \\
\underline{\text { Units }}\end{array}$ & $\frac{\text { \% of Upper }}{\text { Basin }}$ \\
\hline \multicolumn{2}{|c|}{ Elevation of initiation zone $(\mathrm{m})$} & None & Ice & \\
\hline \multicolumn{2}{|c|}{ Total Basin Area $\left(\mathrm{m}^{2}\right)$} & 13642000 & Glacier & 11 \\
\hline \multicolumn{2}{|l|}{ Upper Basin Area $\left(\mathrm{m}^{2}\right)$} & 3684090 & Dacite & \\
\hline \multicolumn{2}{|c|}{ Distance from the glacier $(\mathrm{m})$} & 50 & Qvd(a) & 0 \\
\hline \multicolumn{2}{|l|}{ Glacier Area $\left(\mathrm{m}^{2}\right)$} & 392240 & Basalt & \\
\hline \multicolumn{2}{|c|}{ Surface Connection to the Glacier } & No & Qvb(gt) & 0 \\
\hline \multicolumn{2}{|c|}{ Highest Elevation of the Basin (m) } & 2670 & Qvb(ri) & 0 \\
\hline \multicolumn{2}{|c|}{ Basin Height $(\mathrm{m})$} & 1590 & Qvb(rb) & 0 \\
\hline \multicolumn{2}{|l|}{ Upper Basin Length (m) } & 3720 & Andesite & \\
\hline \multicolumn{2}{|l|}{ Upper Basin Gradient } & 0.24 & Qva(a) & 84 \\
\hline \multicolumn{2}{|l|}{ Percent Vegetation } & 18 & Qva(ah) & 0 \\
\hline \multicolumn{2}{|l|}{ Percent Steep Slopes } & 3 & Qva(hb) & 0 \\
\hline \multicolumn{2}{|c|}{ Melton's Ruggedness number } & 0.43 & Qva(sb) & 0 \\
\hline \multicolumn{2}{|c|}{ Grain Size Average Sand Percent } & 61.4 & Qvba(Im) & 0 \\
\hline \multicolumn{2}{|c|}{ Average Annual Precipitation (m) } & 2.4 & Glacial Drift & \\
\hline \multicolumn{2}{|c|}{ Glacier Area Lost From 1904-2006 $\left(\mathrm{m}^{2}\right)$} & 3250000 & Qad & 6 \\
\hline \multicolumn{2}{|c|}{ Percent Glacier area lost 1904-2006 } & -47 & Qad(md) & 0 \\
\hline \multicolumn{2}{|c|}{ Glacier Area Lost From 1998-2006 $\left(\mathrm{m}^{2}\right)$} & 840000 & Volcaniclastic & \\
\hline & Qvc(a) & 0 \\
\hline \multicolumn{3}{|l|}{ Major Geologic Units } & & \\
\hline Ice & \multicolumn{2}{|l|}{11} & \multirow{3}{*}{$\begin{array}{l}\text { Bedrock vs. } \\
\text { Unconsolidated } \\
\text { Basalt Andesite }\end{array}$} & \multirow{2}{*}{$\frac{\text { \% of Upper }}{\text { Basin }}$} \\
\hline Dacite & \multicolumn{2}{|l|}{0} & & \\
\hline Basalt & \multicolumn{2}{|l|}{0} & & \multirow{2}{*}{84} \\
\hline Andesite & \multicolumn{2}{|l|}{84} & $\begin{array}{l}\text { Basalt, Andesite, } \\
\text { Dacite }\end{array}$ & \\
\hline Glacial Drift & 6 & & \multirow{2}{*}{$\begin{array}{l}\text { Volcaniclastic, } \\
\text { Glacial Drift }\end{array}$} & \multirow[b]{2}{*}{6} \\
\hline Volcaniclastic & 0 & & & \\
\hline
\end{tabular}

\subsubsection{Lewis Creek}

Lewis Creek is located on the northwest side of Mt. Adams (Figure 37). It is fairly secluded with access from Trails 112 and 9 or the Pacific Crest Trail. This drainage had evidence of previous debris flow activity. The debris flow activity found in the Lewis Creek Drainage was difficult to date based on the fact that it was only found in the uppermost part of the basin where there is little vegetation. Orthophoto comparisons between pre-storm 2006 and 2009 photos showed an area of change indicating the debris flow had occurred since 2006 and due to a lack of major debris-flow-producing 
storm since 2006 this debris flow most likely occurred in 2006. The Lewis Creek Debris

Flow was small, only travelling about 2,600 m and was initiated by heavy water flow and in channel landslides.

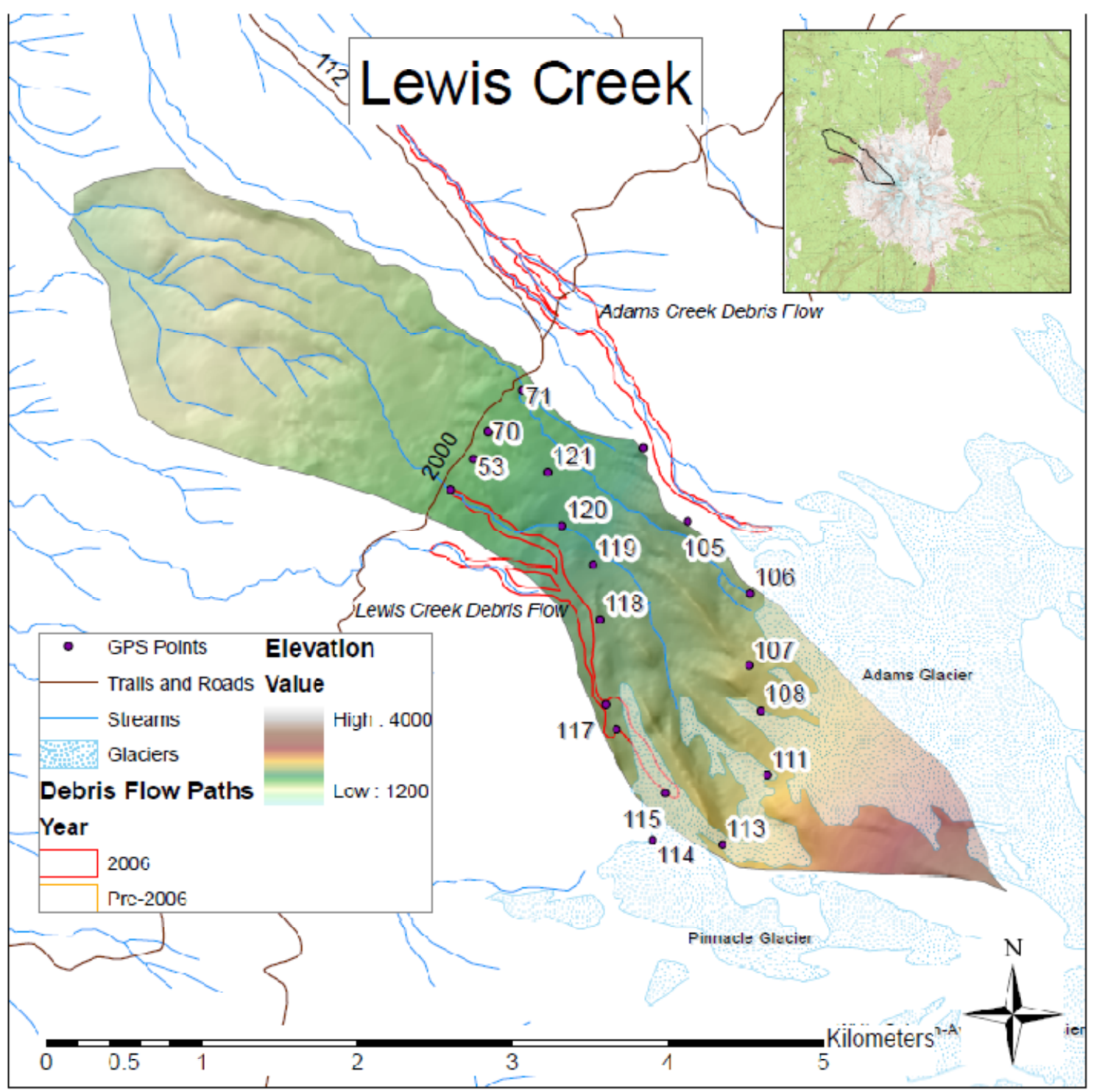

Figure 37: Map of Lewis Creek Drainage. Black numbers are trail and road indicators, black numbers with white halos refer to GPS points. 


\section{Reconnaissance}

Initial reconnaissance was conducted in the summer of 2009. At the location of Trail 9 boulders were found that resembled the shape of a debris flow deposit. No incision or scarps were visible from this location (Figure 38). Vegetation was abundant in the drainage sidewalls and in the channel.

\section{Initiation Zone}

During the summer of 2010 the upper Lewis Creek Drainage was explored by hiking a ridge between the Adams Creek and Lewis Creek drainages, and then across the upper Lewis Creek Basin and into the Upper Riley Creek Basin. In the upper basin area, collapsed moraines and incision were visible in multiple places (Figure 39). An area with evidence of pooled water was also found (Figure 40). This area had a 'V' shaped outlet where further incision was visible downstream. A recent landslide scarp was found just upstream of the area of water pooling (Figure 41). Pooled water could be the result of a landslide damming the outlet of this flat area, or more likely that heavy water flow was slowed due to the narrow outlet causing water to back up and cause slope failures.

Orthophotos were analyzed in the Lewis Creek Drainage. Due to significant snow cover in the $\mathbf{2 0 0 9}$ orthophoto for this area, there was little difference found in the channel activity for the pre-storm 2006 orthophoto and the 2009 orthophoto. However, in the area of the found scarp, a difference can be seen where rock had fallen away from the hillside. This location was determined to be the initiation zone for the Lewis 
Creek Debris Flow. This debris flow was initiated by heavy water flow and in channel landslides.

Oblique air photos of the upper Lewis Creek drainage were taken in the summer of 2010. These photos confirm the presence of debris flow activity not seen in the 2006 pre-storm orthophotos. This debris flow did not travel very far, depositing near the elevation of the round the mountain Trail (Figure 42).

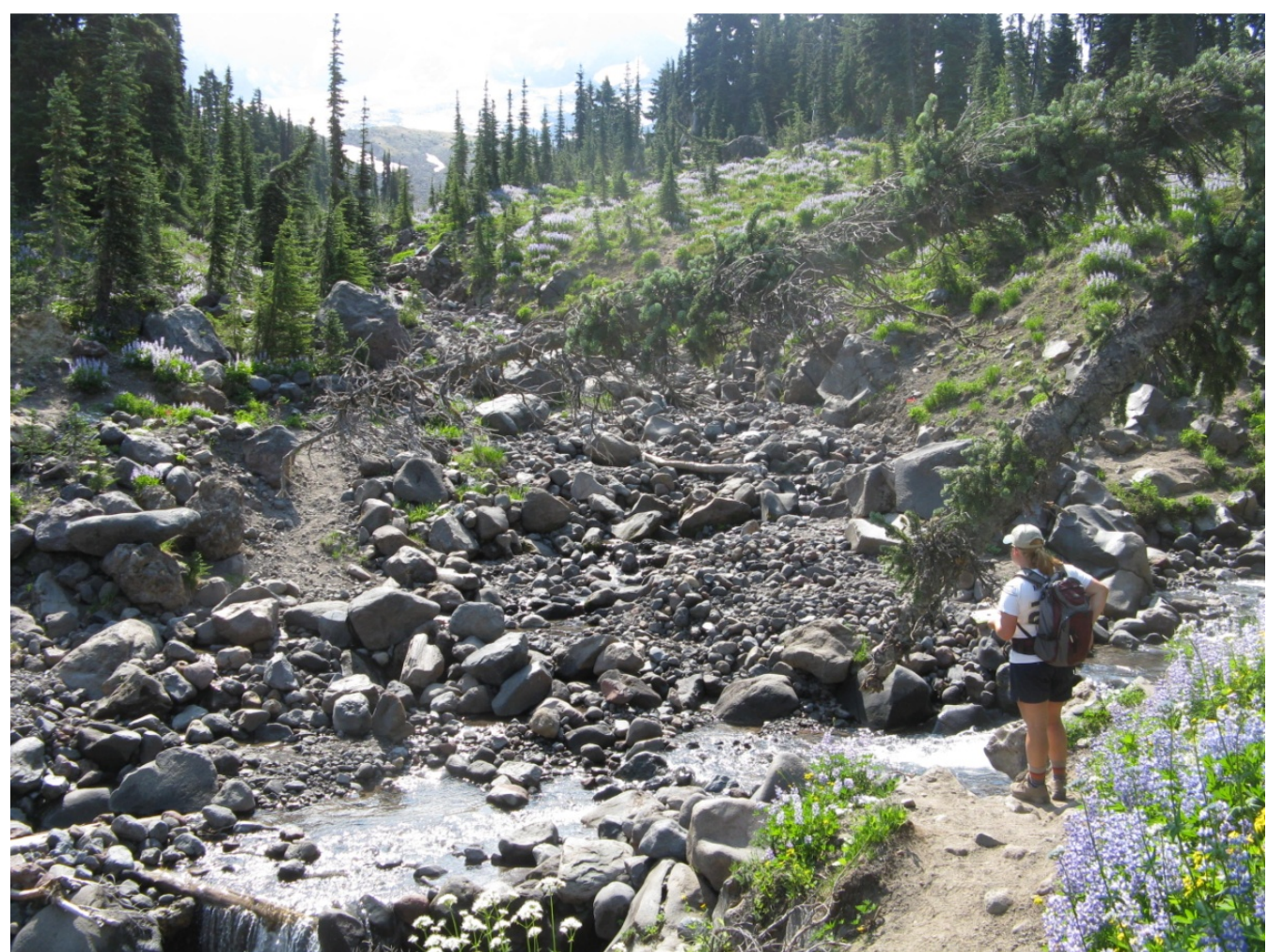

Figure 38: Lewis Creek Drainage at the crossing with Trail 9. Vegetated channel sidewalls are visible. Photo taken during the summer of 2009.

\section{Sample Collection}

Two sets of three soil samples for Lewis Creek were taken from GPS points 111

and 116. The first location was chosen because the elevation was similar to that of other debris flow initiation zones, and the other location was chosen directly next to a visible 
scarp (Figure 41). Sample 111 was taken in an area geologically mapped as Quaternary Andesite flows (Qva) and sample 116 was taken in an area geologically mapped as Quaternary Glacial Drift (Qad) (Department of Natural Resources, 2005).

Sieve Results

Samples from Lewis Creek Drainage are presented in Table 18 along with average values. Bulk densities were measured at 2 and $1.5 \mathrm{~g} / \mathrm{cm}^{3}$, and the samples contained 31 and $32 \%$ gravel, 66 and $67 \%$ sand and 2 and $1 \%$ fines.

Table 18: Lewis Creek sieve results, sample 111 subsets 1, 2 and 3 and sample 116 subsets 1, 2, and 3 (respectively). See Table 1 for exact size definitions. Bottom rows hold the average values.

\begin{tabular}{|c|c|c|c|c|c|c|c|}
\hline \multirow{2}{*}{ \# } & \multirow{2}{*}{$\begin{array}{l}\text { Bulk Density } \\
\text { (g/cm3) }\end{array}$} & \multirow{2}{*}{ Gravel } & \multirow{2}{*}{ Sand } & \multicolumn{3}{|c|}{ Sand Distribution } & \multirow{2}{*}{$\begin{array}{l}\text { Silt \& } \\
\text { Clay }\end{array}$} \\
\hline & & & & Coarse Sand & Medium Sand & Fine Sand & \\
\hline 1 & 2.1 & 33 & 66 & 37 & 26 & 3 & 0.7 \\
\hline 2 & 1.9 & 26 & 72 & 45 & 21 & 6 & 1.1 \\
\hline 3 & 1.9 & 34 & 59 & 33 & 12 & 15 & 5.3 \\
\hline$x$ & $2.0 \pm .1$ & $31 \pm 4.4$ & $66 \pm 6.3$ & $38 \pm 6.5$ & $20 \pm 7.3$ & $8 \pm 6.3$ & $2.4 \pm 2.6$ \\
\hline
\end{tabular}

\begin{tabular}{|c|c|c|c|c|c|c|c|}
\hline \multirow{2}{*}{ \# } & \multirow{2}{*}{$\begin{array}{c}\text { Bulk Density } \\
\text { (g/cm3) }\end{array}$} & \multirow{2}{*}{ Gravel } & \multirow{2}{*}{ Sand } & \multicolumn{3}{|c|}{ Sand Distribution } & \multirow{2}{*}{$\begin{array}{l}\text { Silt \& } \\
\text { Clay }\end{array}$} \\
\hline & & & & Coarse Sand & Medium Sand & Fine Sand & \\
\hline 1 & 1.5 & 35 & 62 & 41.5 & 13 & 8 & 2.3 \\
\hline 2 & 1.4 & 29 & 71 & 56.8 & 13 & 1 & 0.1 \\
\hline 3 & 1.7 & 33 & 66 & 50 & 16 & 1 & 0.3 \\
\hline $\bar{x}$ & $1.5 \pm .2$ & $32 \pm 3$ & $67 \pm 4.3$ & $49 \pm 7.7$ & $14 \pm 1.3$ & $3 \pm 4$ & $0.9 \pm 1.2$ \\
\hline
\end{tabular}




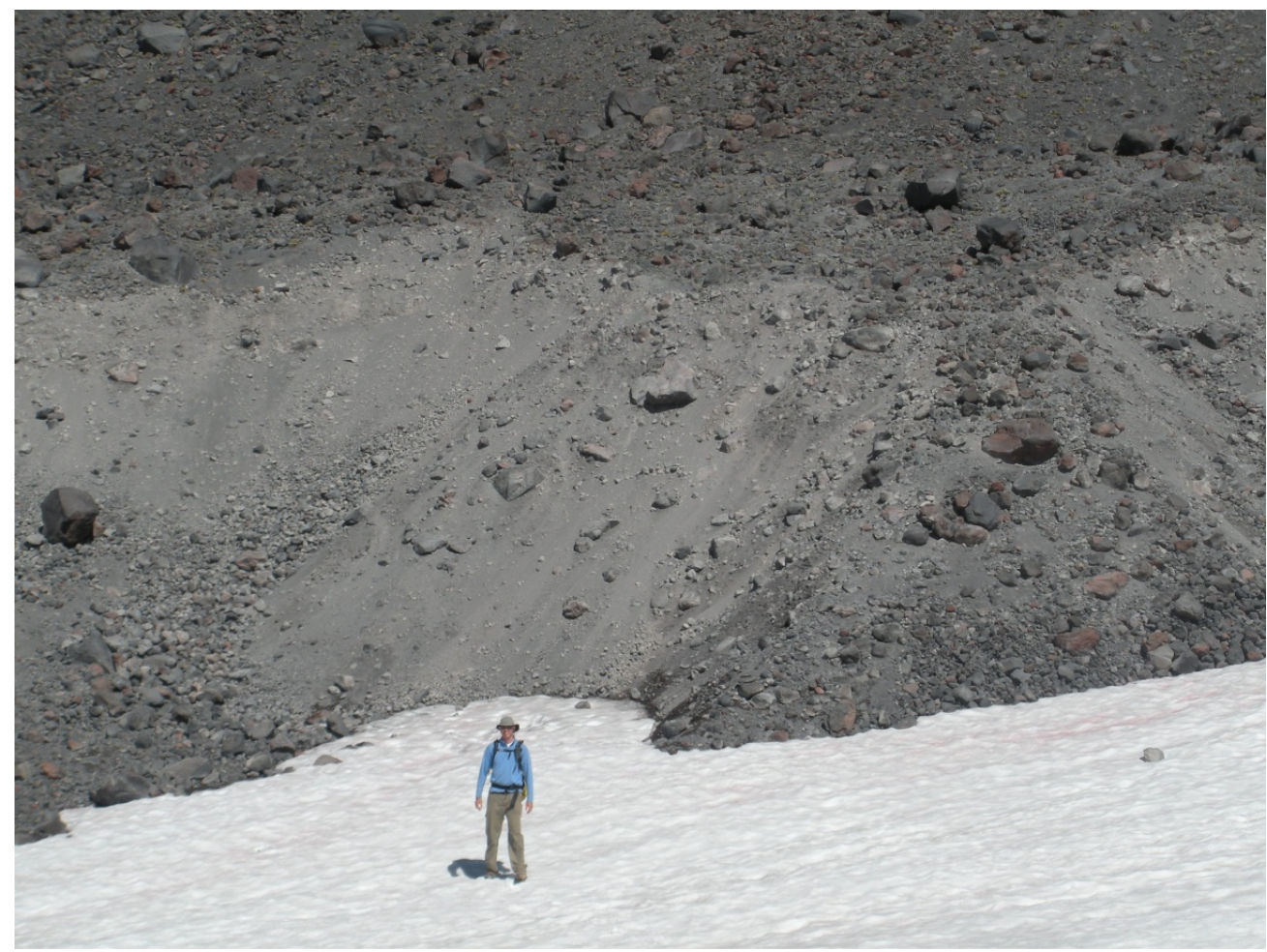

Figure 39: Collapsed moraine in the upper Lewis Creek Drainage Basin. Photo taken during the summer of 2010.

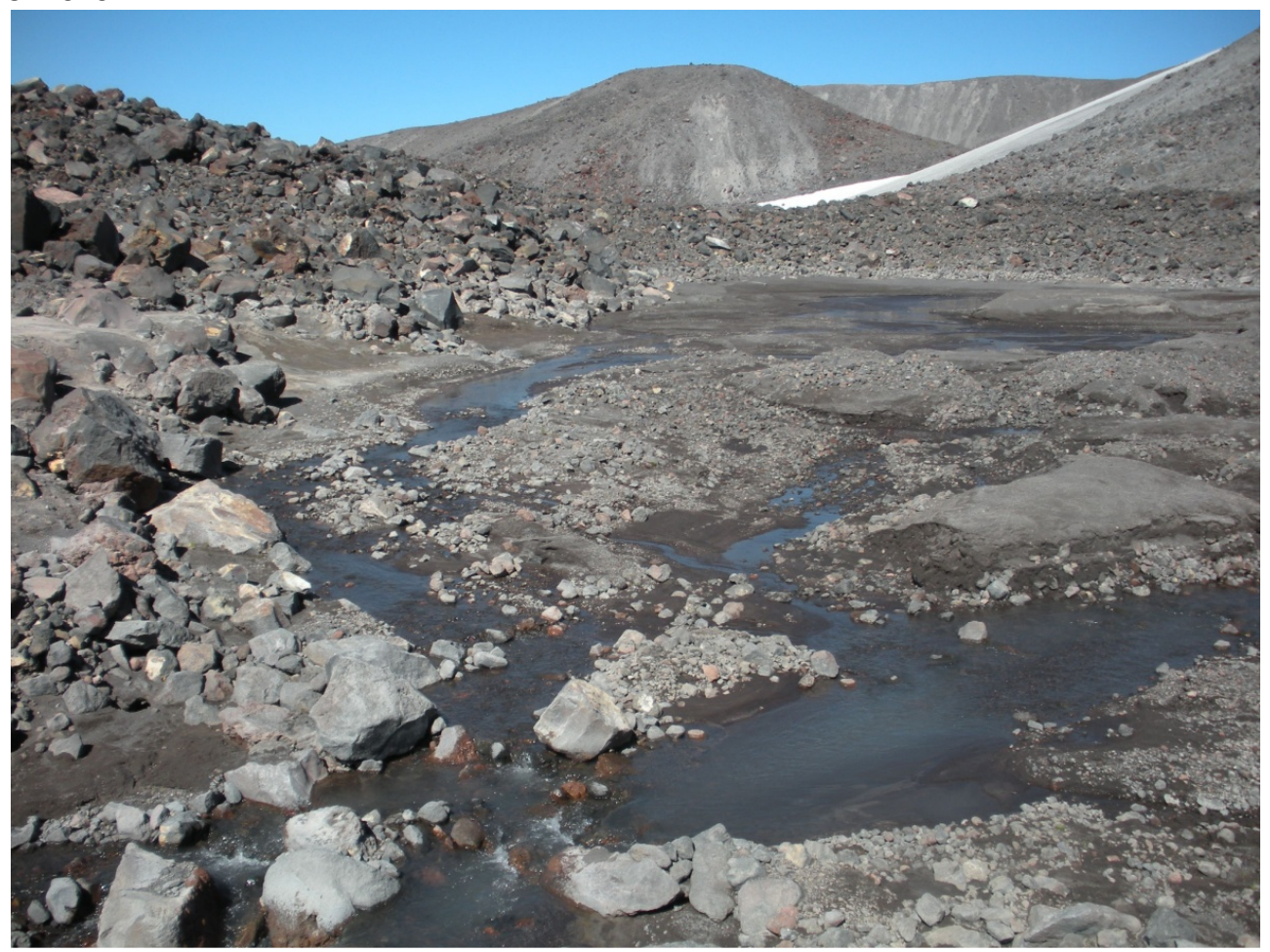

Figure 40: Area of water pooling in the upper Lewis Creek Drainage. Photo taken during the summer of 2010. 


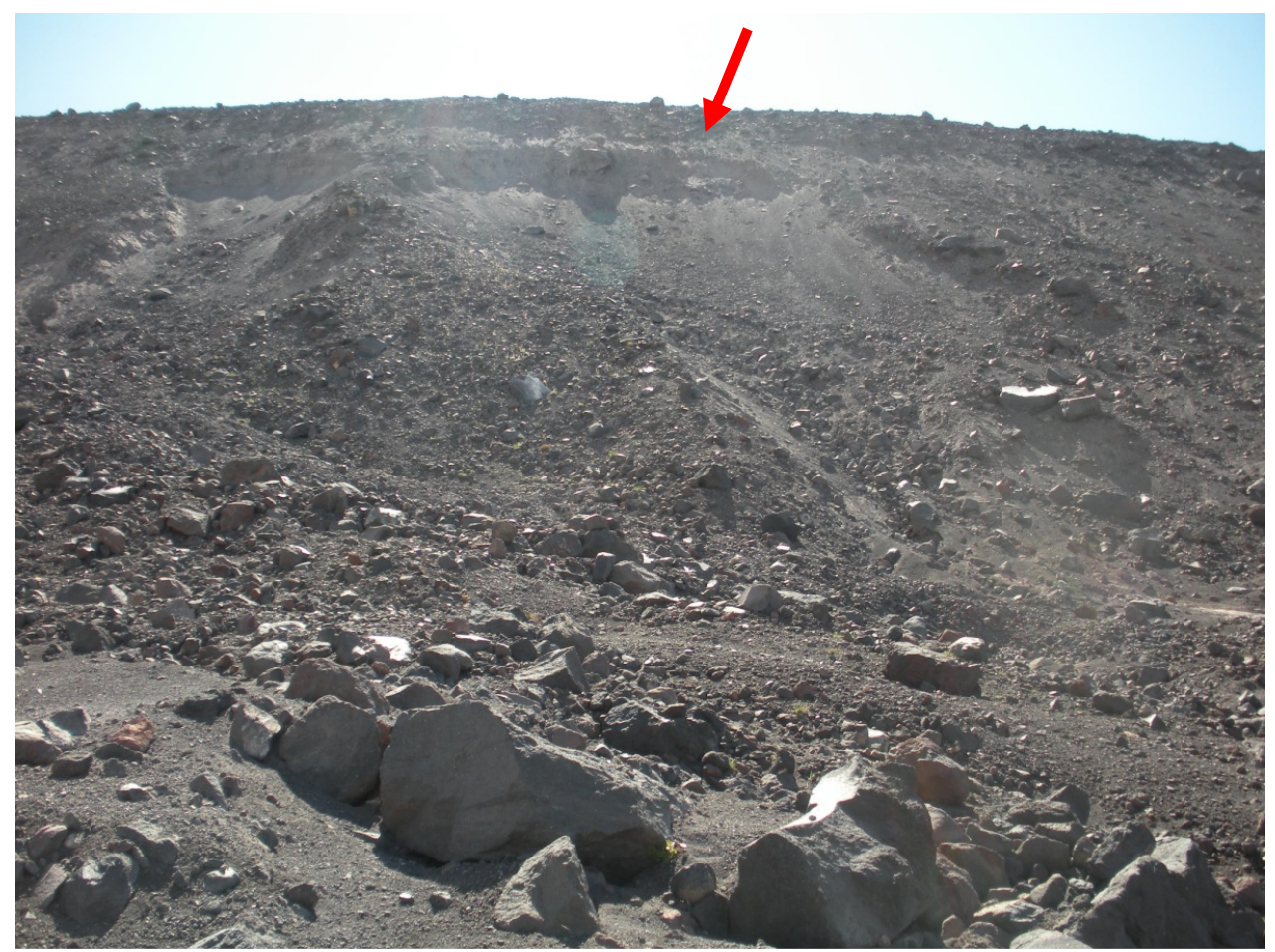

Figure 41: Red Arrow points out a scarp in the upper Lewis Creek Drainage. Sample 116 was taken to the left (upstream) of this scarp. Photo taken during the summer of 2010.

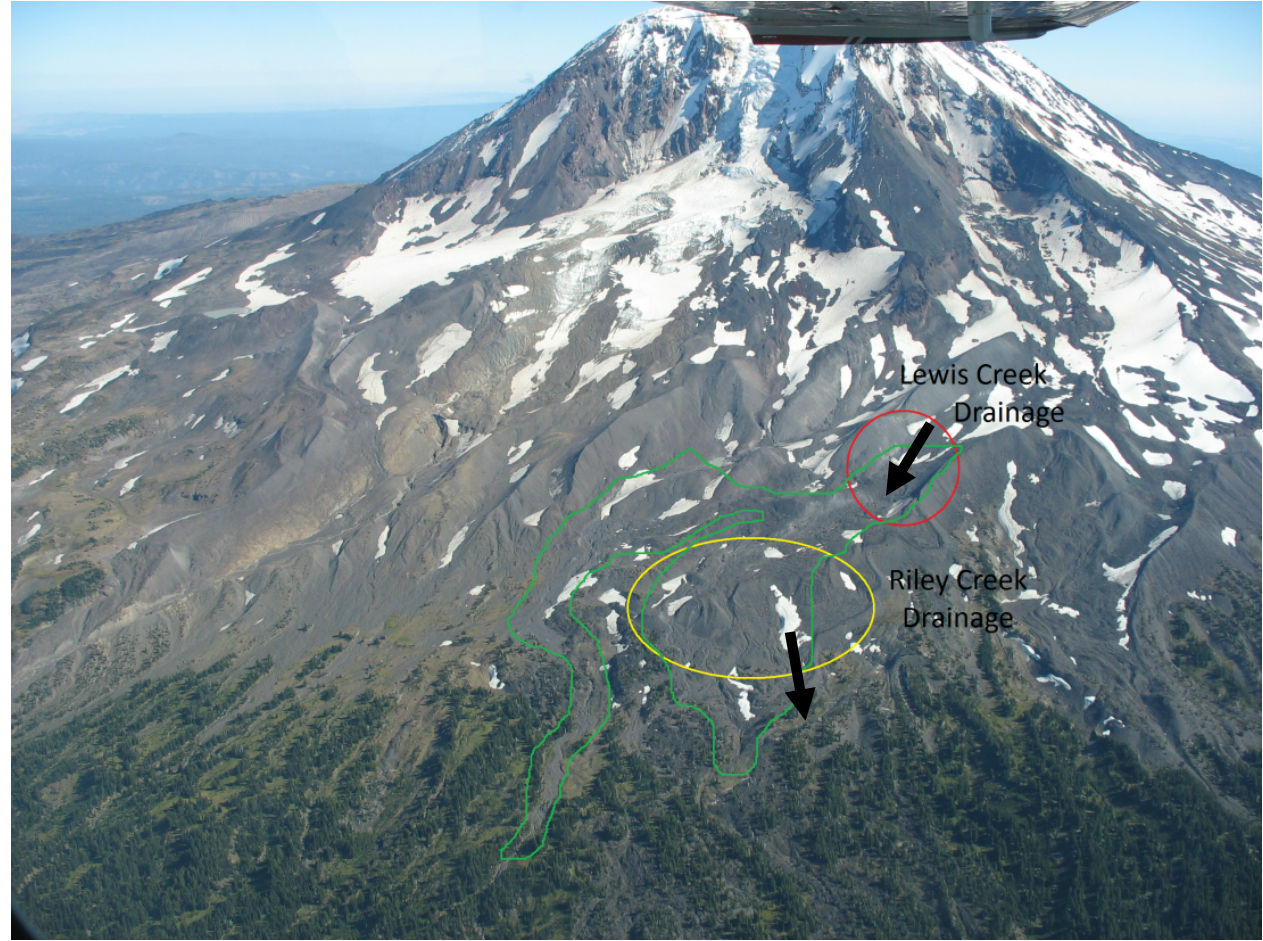

Figure 42: Oblique air photo of the Adams Creek, Lewis Creek and Riley Creek drainages. The red circle is the initiation area and the yellow oval is where the flow crossed in to Riley Creek. The green outline is the affected area. The black arrows point downs slope. Photo taken September $30^{\text {th }}, 2010$. 
Table 19: Lewis Creek Drainage Basin attributes

\begin{tabular}{|c|c|c|c|c|}
\hline \multicolumn{2}{|l|}{ Factor } & $\underline{\text { Value }}$ & $\begin{array}{l}\text { All Geologic } \\
\text { Units }\end{array}$ & $\begin{array}{l}\text { \% of Upper } \\
\text { Basin }\end{array}$ \\
\hline \multicolumn{2}{|c|}{ Elevation of initiation zone (m) } & 2200 & Ice & \\
\hline \multicolumn{2}{|c|}{ Total Basin Area $\left(\mathrm{m}^{2}\right)$} & 8579020 & Glacier & 31 \\
\hline \multicolumn{2}{|l|}{ Upper Basin Area $\left(\mathrm{m}^{2}\right)$} & 4870640 & Dacite & \\
\hline \multicolumn{2}{|c|}{ Distance from the glacier $(\mathrm{m})$} & 25 & Qvd(a) & 0 \\
\hline \multicolumn{2}{|l|}{ Glacier Area $\left(\mathrm{m}^{2}\right)$} & 1505970 & Basalt & \\
\hline \multicolumn{2}{|c|}{ Surface Connection to the Glacier } & Yes & Qvb(gt) & 0 \\
\hline \multicolumn{2}{|c|}{ Highest Elevation of the Basin (m) } & 3260 & Qvb(ri) & 0 \\
\hline \multicolumn{2}{|c|}{ Basin Height $(\mathrm{m})$} & 1800 & $\mathrm{Qvb}(\mathrm{rb})$ & 0 \\
\hline \multicolumn{2}{|l|}{ Upper Basin Length (m) } & 5180 & Andesite & \\
\hline \multicolumn{2}{|l|}{ Upper Basin Gradient } & 0.29 & Qva(a) & 10 \\
\hline \multicolumn{2}{|l|}{ Percent Vegetation } & 9 & Qva(ah) & 10 \\
\hline \multicolumn{2}{|l|}{ Percent Steep Slopes } & 8 & Qva(hb) & 0 \\
\hline \multicolumn{2}{|c|}{ Melton's Ruggedness number } & 0.61 & Qva(sb) & 0 \\
\hline \multicolumn{2}{|c|}{ Grain Size Average Sand Percent } & 66 & Qvba(Im) & 0 \\
\hline \multicolumn{2}{|c|}{ Average Annual Precipitation (m) } & 2.9 & Glacial Drift & \\
\hline \multicolumn{2}{|c|}{ Glacier Area Lost From 1904-2006 (m²) } & 3250000 & Qad & 40 \\
\hline \multicolumn{2}{|c|}{ Percent Glacier area lost 1904-2006 } & -47 & Qad(md) & 0 \\
\hline \multicolumn{2}{|c|}{ Glacier Area Lost From 1998-2006 (m²) } & 840000 & Volcaniclastic & \\
\hline & Qvc(a) & 9 \\
\hline \multirow{2}{*}{ Major Geologic Units } & \multicolumn{2}{|c|}{ \% of Upper Basin } & \multirow{3}{*}{$\begin{array}{l}\text { Bedrock vs. } \\
\text { Unconsolidated }\end{array}$} & \\
\hline & \multicolumn{2}{|c|}{31} & & \% of Upper \\
\hline Dacite & \multicolumn{2}{|l|}{0} & & Basin \\
\hline Basalt & \multicolumn{2}{|l|}{0} & \multirow{2}{*}{$\begin{array}{l}\text { Basalt, Andesite, } \\
\text { Dacite }\end{array}$} & \\
\hline Andesite & \multicolumn{2}{|l|}{20} & & 20 \\
\hline Glacial Drift & \multicolumn{2}{|l|}{40} & \multirow{2}{*}{$\begin{array}{l}\text { Volcaniclastic, } \\
\text { Glacial Drift }\end{array}$} & \\
\hline Volcaniclastic & 9 & & & 49 \\
\hline
\end{tabular}

\section{Basin Attributes}

The total Lewis Creek Basin area is $8.6 \mathrm{~km}^{2}$, and the upper basin is $4.9 \mathrm{~km}^{2}$. The distance from the stream beginning to the glacier is 25 meters and $1.5 \mathrm{~km}^{2}$, or $31 \%$, of the upper basin is covered in glaciers. The stream is directly connected to the glacier. The highest elevation of the basin is $3,260 \mathrm{~m}$, the basin height is $1,800 \mathrm{~m}$, and the basin length is $5,180 \mathrm{~m}$. The gradient of the upper basin is $0.29,9 \%$ of the upper basin is vegetated and $8 \%$ are steep slopes. MRN is calculated as 0.61 , and the average annual precipitation is $2.9 \mathrm{~m}$. 


\subsubsection{Little Muddy Creek}

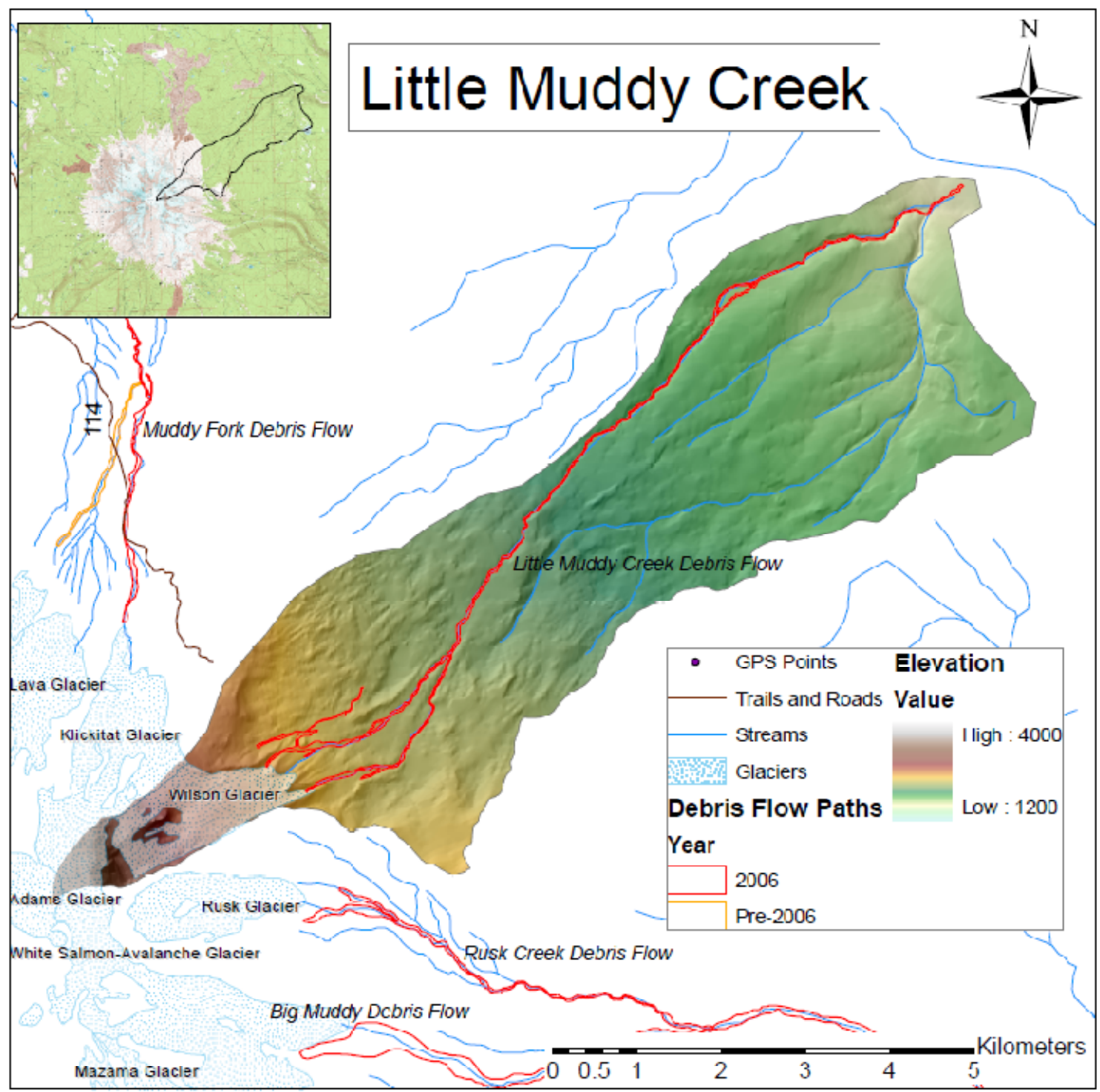

Figure 43: Map of Little Muddy Creek Drainage. Black numbers are trail and road indicators, black numbers with white halos refer to GPS points.

Little Muddy Creek is located on the northeast side of Mt. Adams (Figure 43). This drainage is located in a very remote part of the Yakama Reservation. There is no official access to this drainage. Because of this difficulty, orthophotos and oblique air photos were used to determine that this drainage had evidence of previous debris flow activity. 
Differences were found between the 2006 and 2009 orthophotos, and due to the lack of a major debris flow producing event since 2006, the debris flow activity of the Little Muddy Creek most likely occurred in 2006. This debris flow travelled a very long distance, about $11,000 \mathrm{~m}$. However, an area of deposition was not found suggesting this debris flow either dispersed into a larger river, the West Fork of the Klickitat River, or was small in volume.

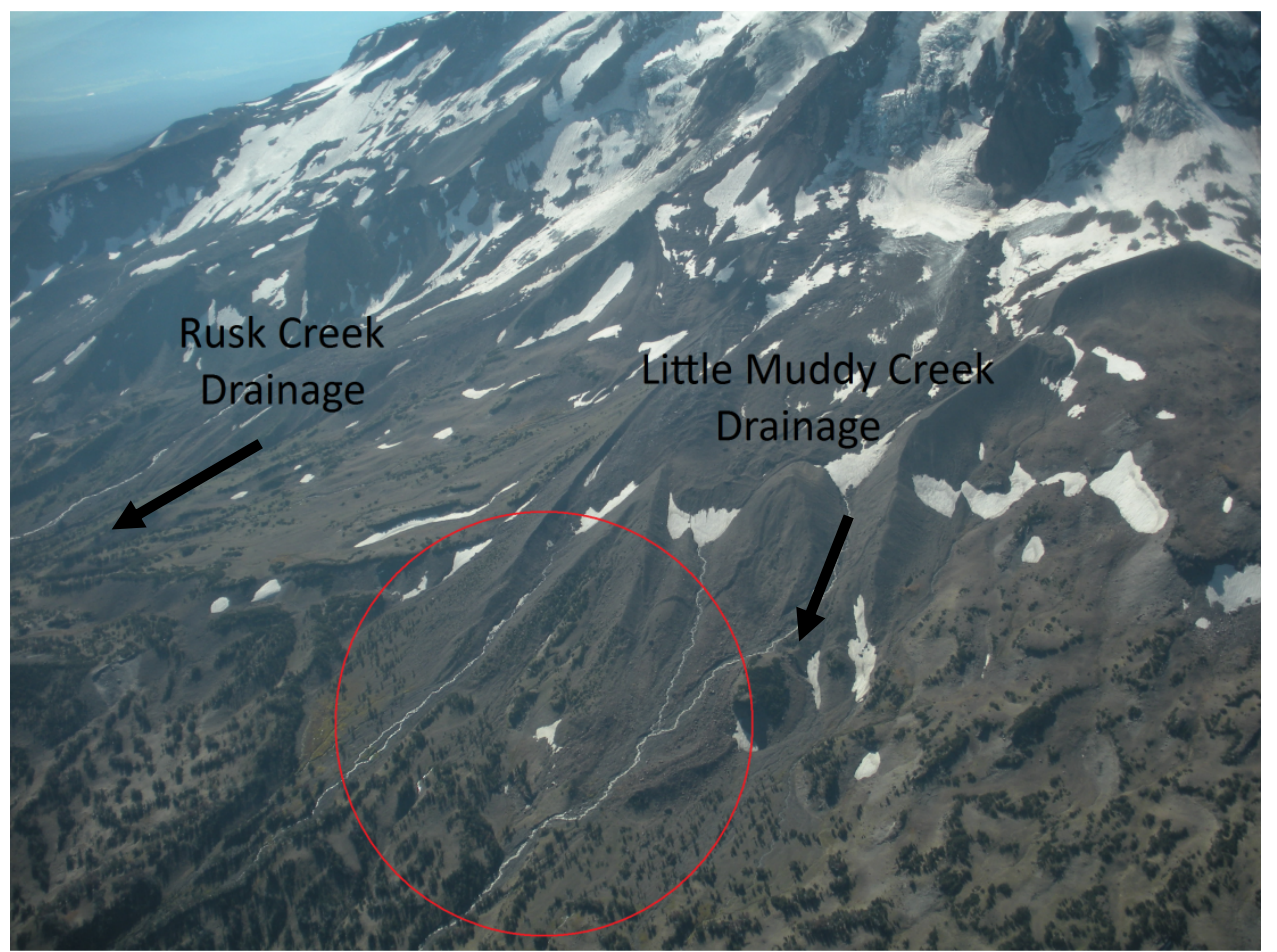

Figure 44: Oblique air photo of the Little Muddy Creek Drainage. The red circle shows the eroded upper channels that coalesce lower in the drainage. Black arrows point down slope. Photo taken September $30^{\text {th }}, 2010$.

\section{Reconnaissance}

Due to limited field season, a large study area and difficulty of access,

orthophotos and oblique air photos were used to determine debris flow activity for Little Muddy Creek. The oblique air photos showed that in the upper basin area, there is 
some channel incision as well as some areas of collapse (Figures 44 and 45). Orthophoto analysis of the drainage showed several areas of difference in the channel between the pre-storm 2006 photo and the 2009 photo.

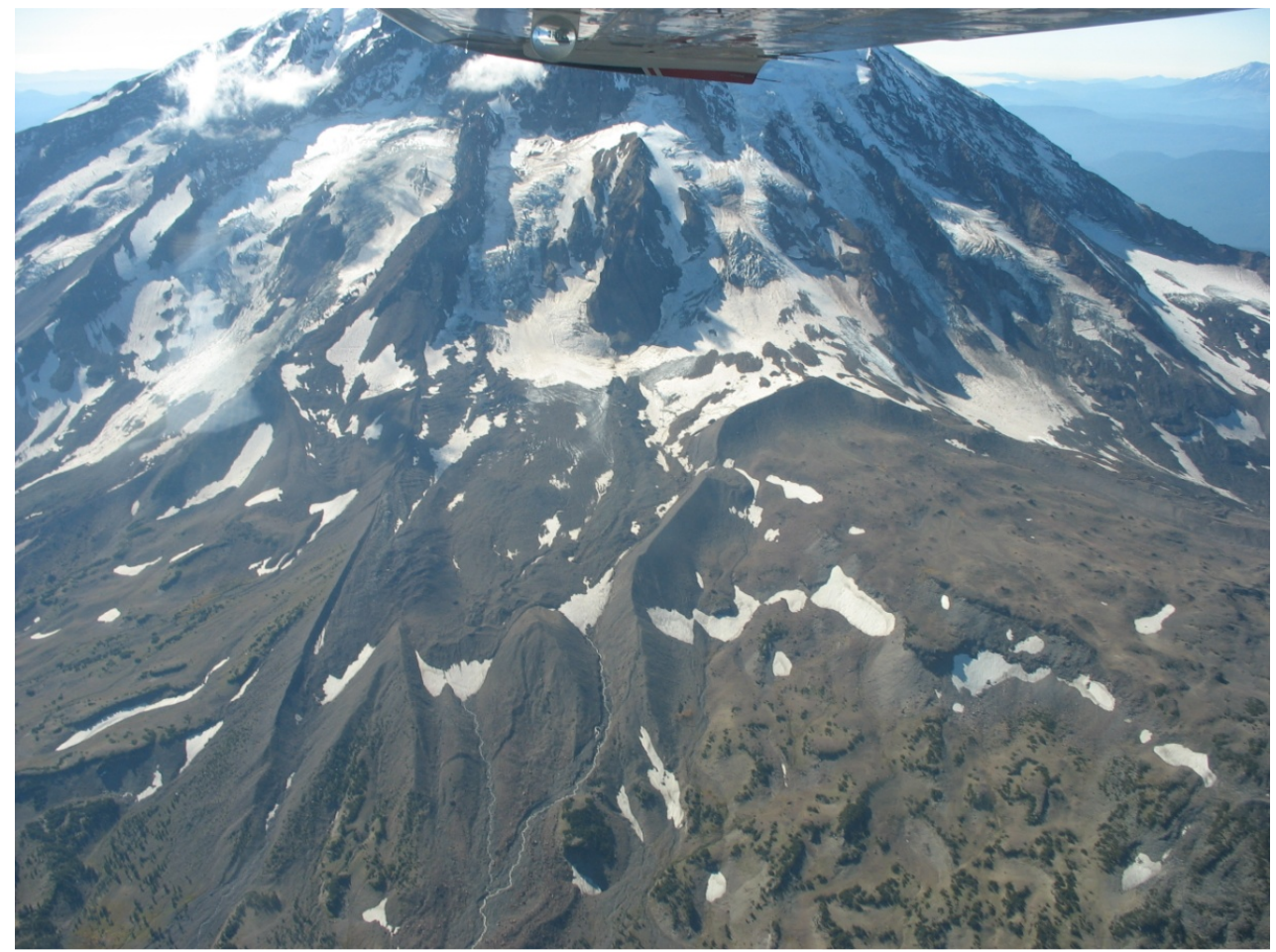

Figure 45: Oblique air photo of the Little Muddy Drainage. This photo shows another angle of Figure 44. Photo taken September $30^{\text {th }}, 2010$.

\section{Initiation Zone}

During the summer of 2010 oblique air photos were taken of the upper Little Muddy Creek. While these photos showed debris flow activity, a single initiation zone could not be identified. Instead the initiation zone consists of several areas of erosion coalescing into one debris flow channel. 
Table 20: Little Muddy Creek Drainage Basin attributes

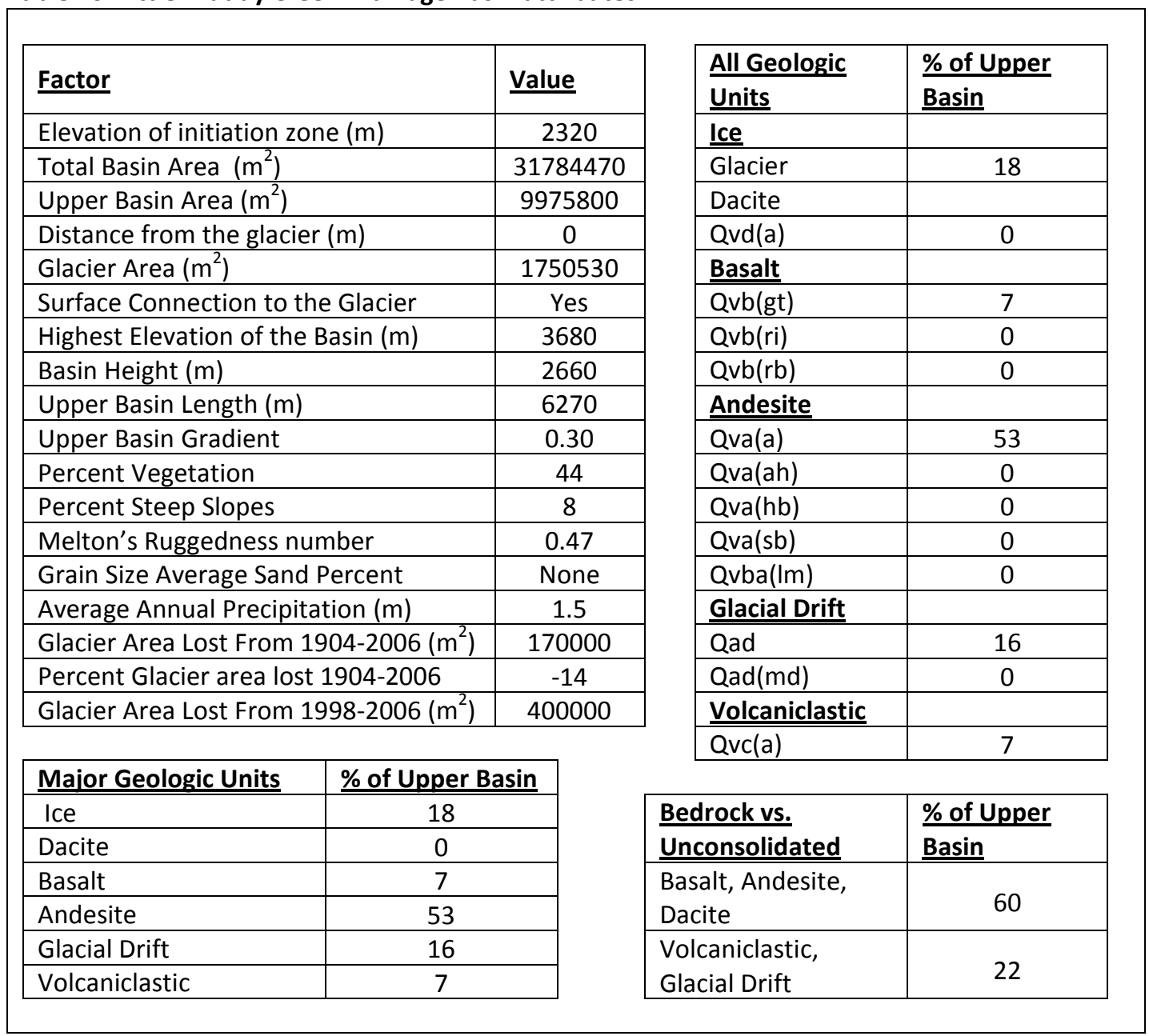

\section{Sample Collection \& Sieve Results}

Due to limited field season, a large study area and difficulty of access samples were not collected for Little Muddy Creek.

\section{Basin Attributes}

The total Little Muddy Creek Basin area is $31.8 \mathrm{~km}^{2}$, and the upper basin is 10.0 $\mathrm{km}^{2}$. The distance from the stream beginning to the glacier is zero meters and $1.8 \mathrm{~km}^{2}$, or $18 \%$, of the upper basin is covered in glaciers. The stream is directly connected to the glacier. The highest elevation of the basin is $3,680 \mathrm{~m}$, the basin height is $2,660 \mathrm{~m}$, and 
the basin length is $6,270 \mathrm{~m}$. The gradient of the upper basin is $0.3,44 \%$ of the upper basin is vegetated and $8 \%$ are steep slopes. MRN is calculated as 0.47 , and the average annual precipitation is $1.5 \mathrm{~m}$.

\subsubsection{Morrison Creek}

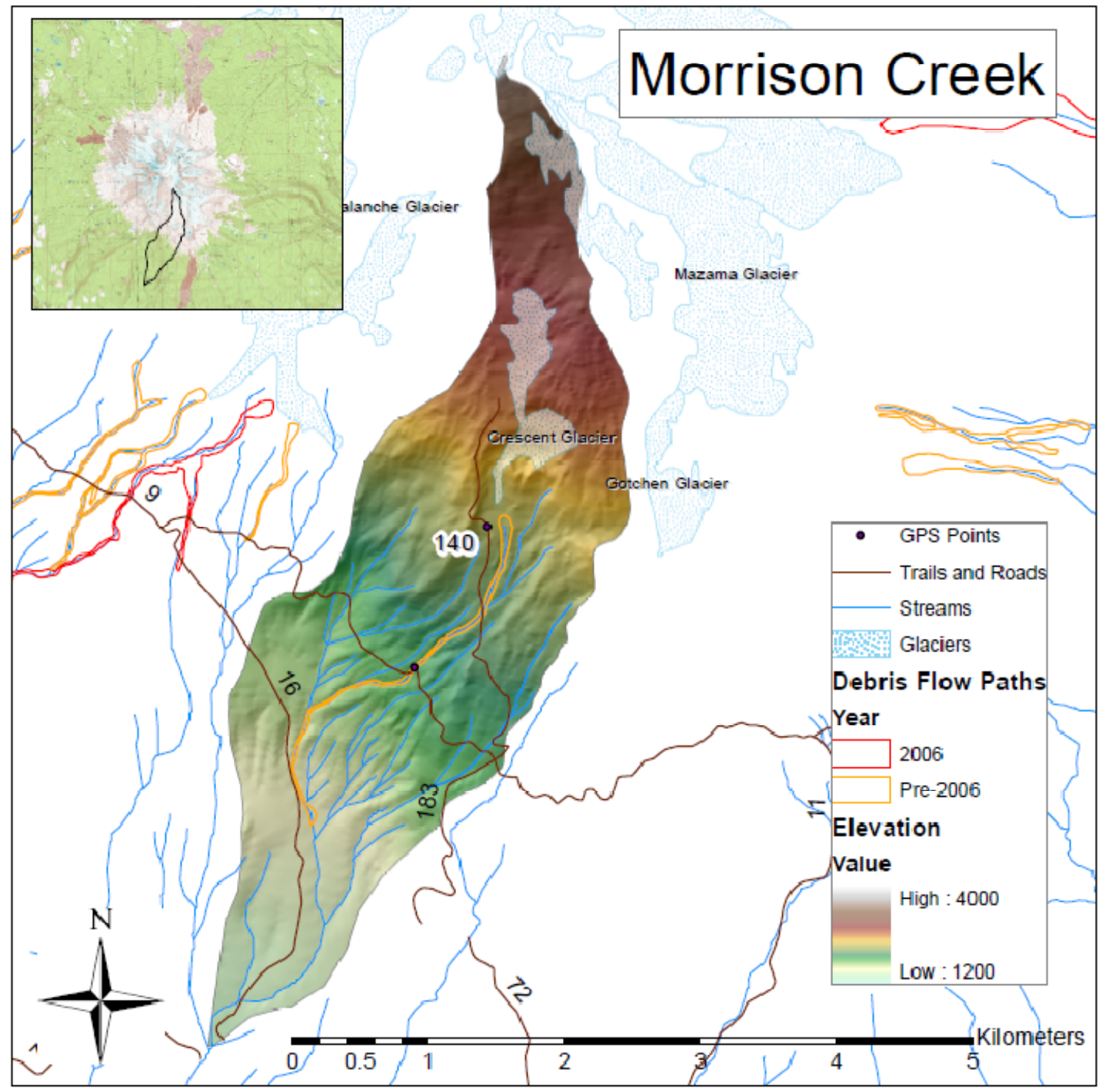

Figure 46: Map of Morrison Creek Drainage. Black numbers are trail and road indicators, black numbers with white halos refer to GPS points. 
Morrison Creek is located on the south side of Mt. Adams (Figure 46). This

drainage is one of the most popular areas on the mountain and is accessible from Trail 183. This drainage is highly visited because it houses the most popular summit climbing route. Some debris flow characteristics were observed for this drainage, however, no distinct debris flow channels or deposits were found. This drainage has most likely experienced a debris flow in its history but it occurred before the 2006 storm.

\section{Reconnaissance}

Initial reconnaissance was conducted in the summer of 2009. Following Trail 183 and 9 in the Morrison Creek Drainage a small creek was passed. Some larger boulders were present in the stream that resembled a weathered debris flow deposit (Figure 47). Vegetation appeared abundant, and no evidence of incision was found.

\section{Initiation Zone}

During the summer of 2010 the upper Morrison Creek Drainage was explored by hiking up Trail 183 to an approximate elevation of 3,140 m. At high elevations the drainage became wide with several draining stream channels and intermittent areas that looked like channel incision (Figure 48). In addition, an area with ' $V$ ' shaped cuts into moraine material was found (Figure 49). Sandy mud-coated boulders were found at high elevations as well (Figure 50). Although the ' $\mathrm{V}$ ' shaped cuts in moraines appeared similar to other initiation zones, no distinct initiation area could be found in the Morrison Creek Drainage. 


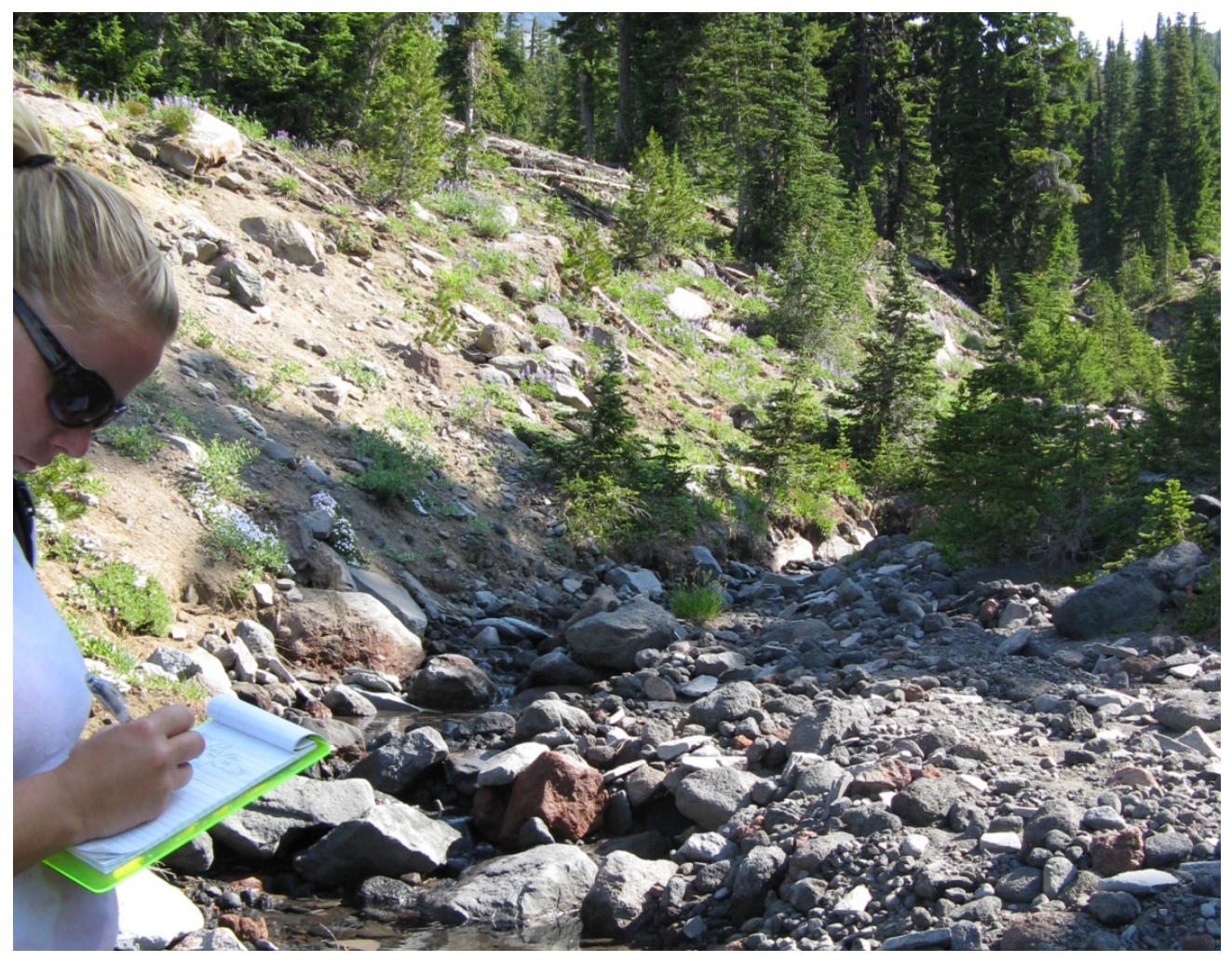

Figure 47: Morrison Creek Drainage at the crossing with Trail 9. Photo taken during the summer of 2009.

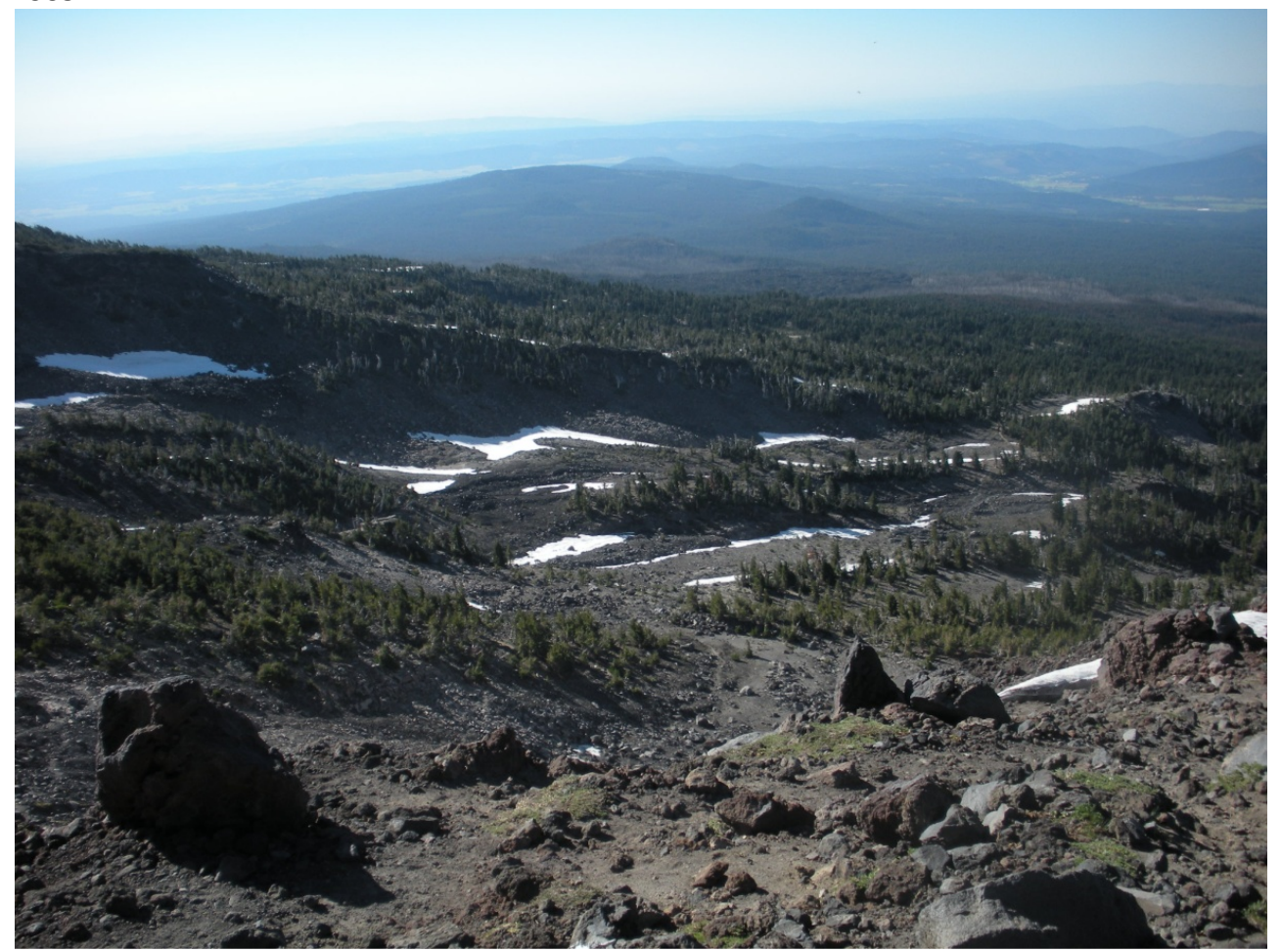

Figure 48: Upper Morrison Creek Drainage. Photo taken during the summer of 2010. 


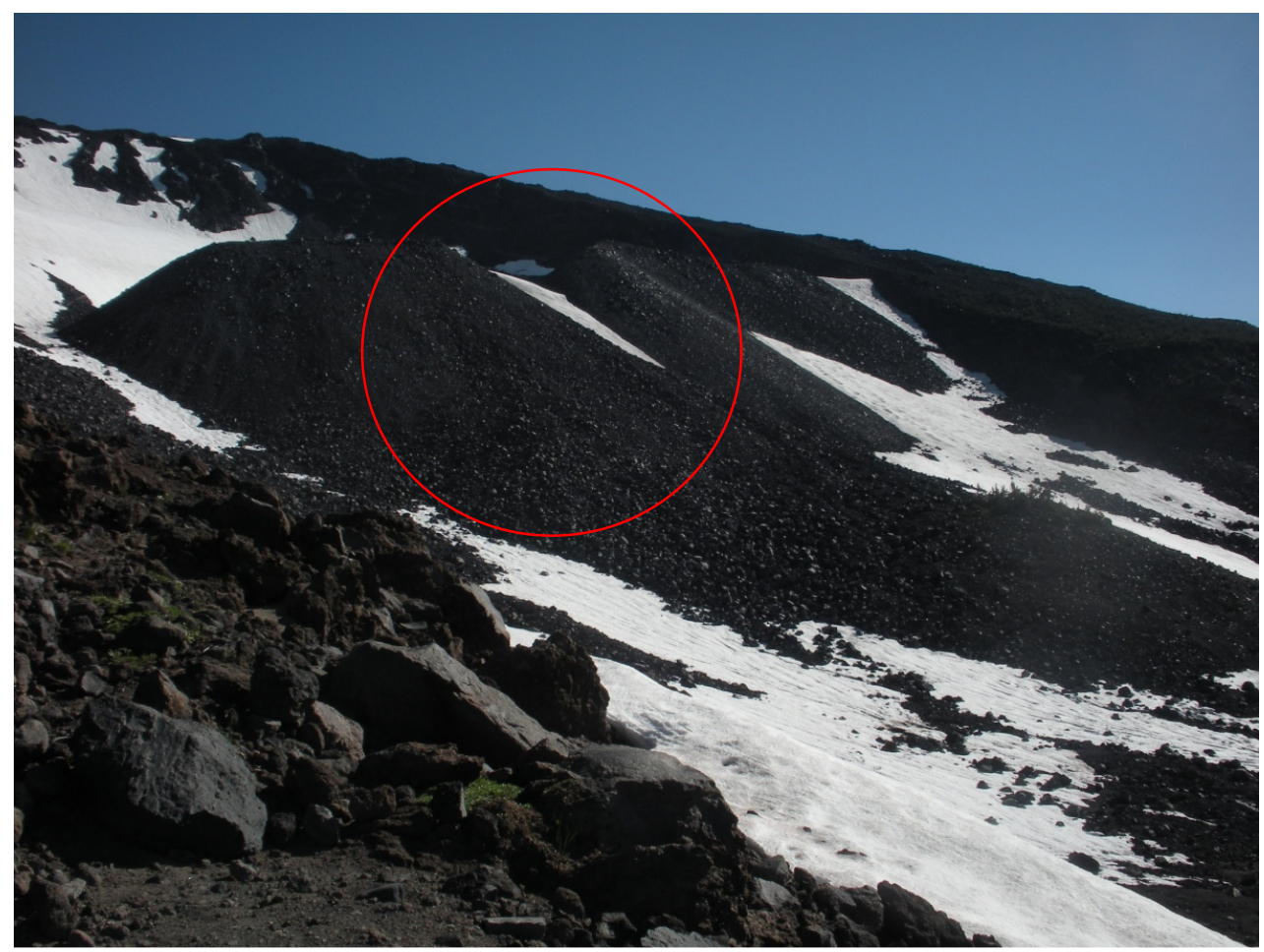

Figure 49: Upper Morrison Creek Drainage. Red circle shows moraine with a 'V' shaped incision. Photo taken during the summer of 2010.

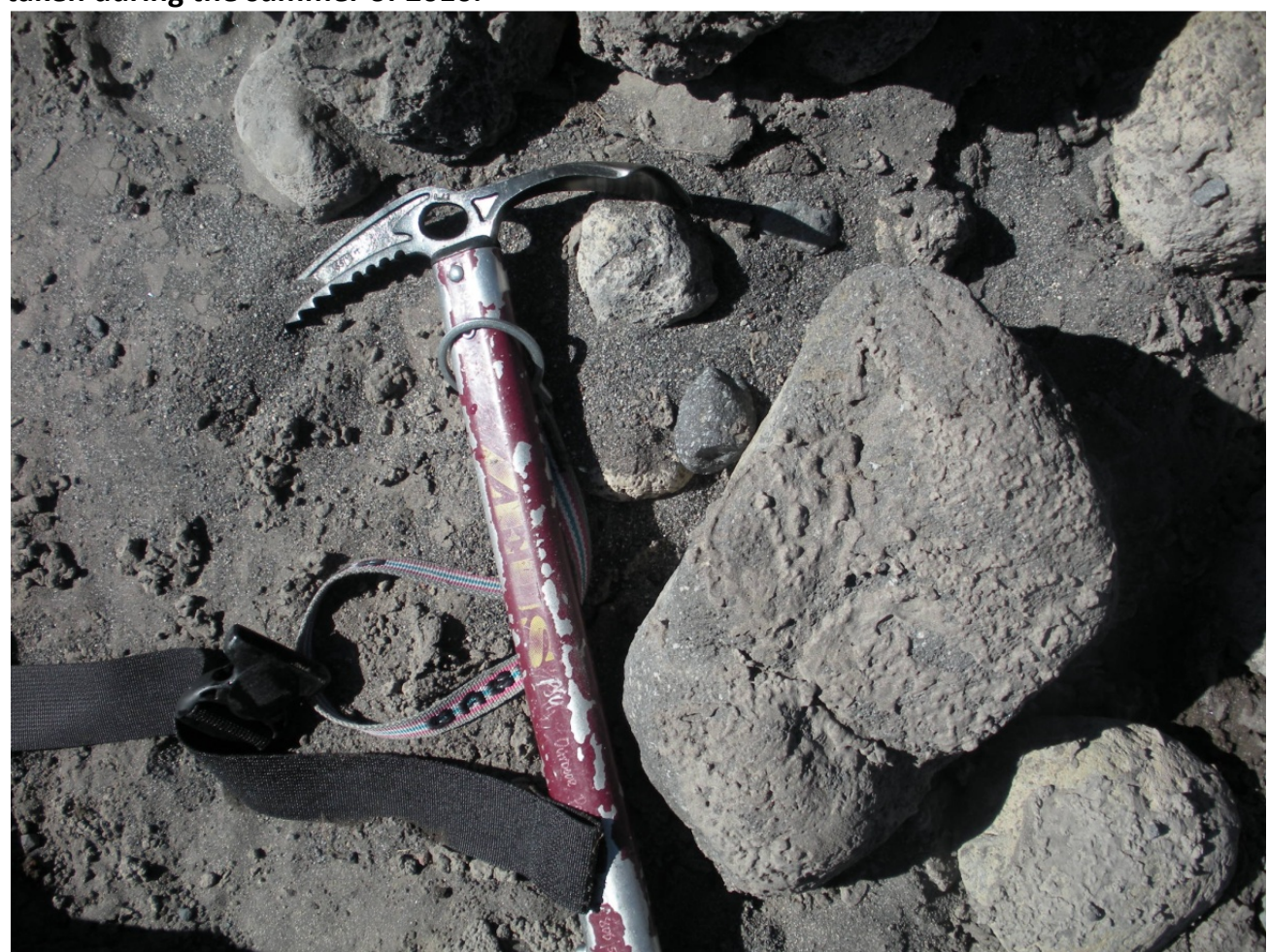

Figure 50: Sandy-mud coated boulders in the upper Morrison Creek Drainage. Although very indicative of a recent debris flow, the lack of other recent defining characteristics made the conclusion that this drainage did not experience a 2006 debris flow. Photo taken during the summer of 2010. 


\section{Sample Collection}

Three soil samples for Morrison Creek were taken from GPS point 140. However, during the hike down, the sample bags failed and all three samples ended up being in one container. This sampling location was chosen because the elevation was similar to that of other debris flow initiation zones. It was taken in an area geologically mapped as Quaternary Andesite Flows (Qva) (Department of Natural Resources, 2005).

Sieve Results

Sample from Morrison Creek Drainage is presented in Table 21, the sample contained $47 \%$ gravel, $52 \%$ sand and $1 \%$ fines.

Table 21: Morrison Creek sieve results, sample 140. See Table 1 for exact size definitions.

\begin{tabular}{|c|c|c|c|c|c|c|c|}
\hline \multirow{2}{*}{$\#$} & Bulk Density (g/cm3) & \multirow{2}{*}{ Gravel } & \multirow{2}{*}{ Sand } & \multicolumn{3}{|c|}{ Sand Distribution } & \multirow{2}{*}{$\begin{array}{c}\text { Silt \& } \\
\text { Clay }\end{array}$} \\
\cline { 5 - 7 } & & & & Coarse Sand & Medium Sand & Fine Sand & \\
\hline 1 & None & 47 & 52 & 43 & 5 & 4 & 1.4 \\
\hline
\end{tabular}

\section{Basin Attributes}

The total Morrison Creek Basin area is $9.2 \mathrm{~km}^{2}$, and the upper basin is $5.0 \mathrm{~km}^{2}$. The distance from the stream beginning to the glacier is 440 meters and $0.6 \mathrm{~km}^{2}$, or $11 \%$, of the upper basin is covered in glaciers. The stream is not directly connected to the glacier. The highest elevation of the basin is $3,540 \mathrm{~m}$, the basin height is $2,130 \mathrm{~m}$, and the basin length is $4,700 \mathrm{~m}$. The gradient of the upper basin is $0.40,6 \%$ of the upper basin is vegetated and $9 \%$ are steep slopes. MRN is calculated as 0.70 , and the average annual precipitation is $2.3 \mathrm{~m}$. 
Table 22: Morrison Creek Drainage Basin attributes

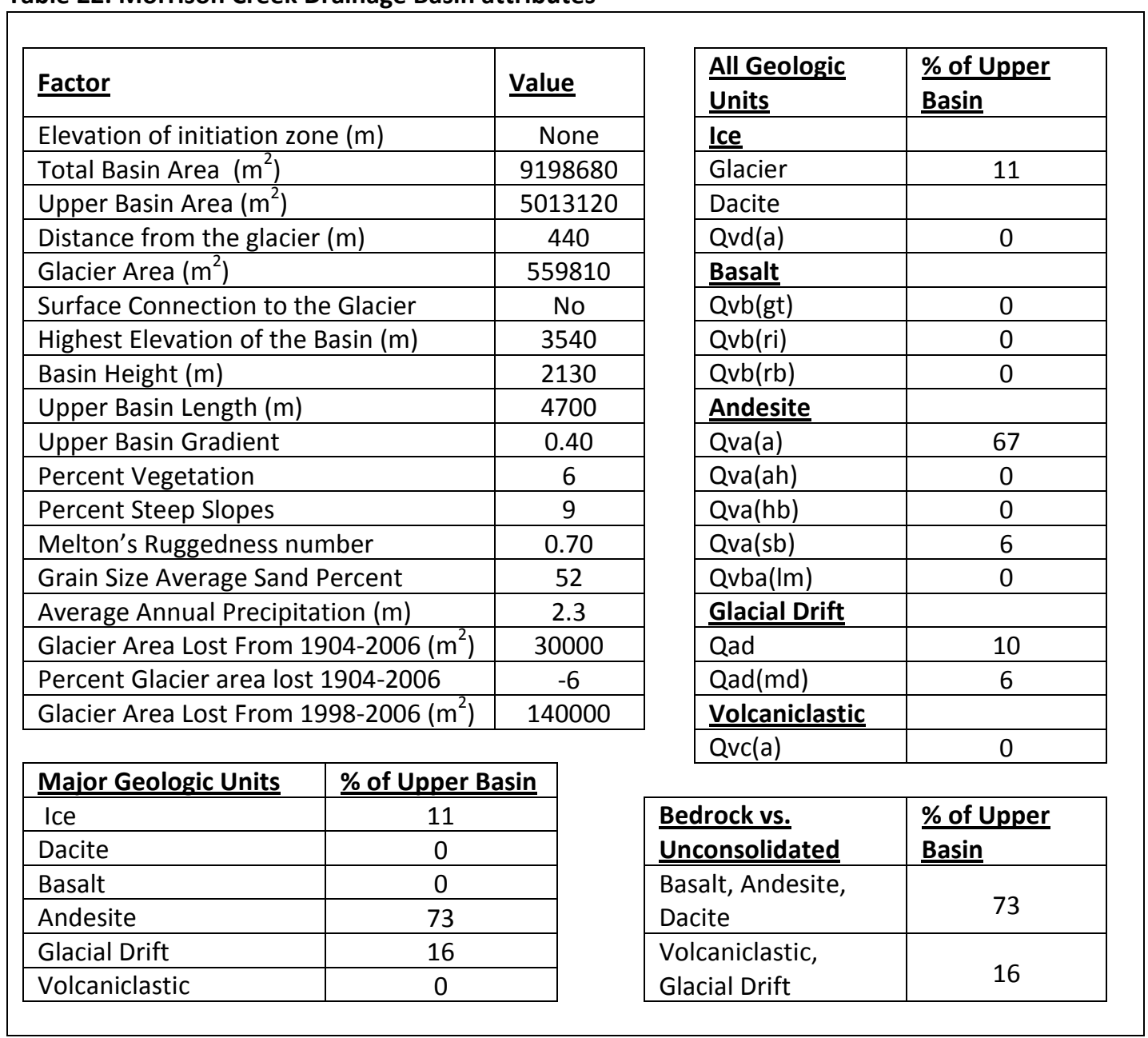

\subsubsection{Muddy Fork}

Muddy Fork is located on the northern side of Mt. Adams (Figure 51). It is fairly secluded with access from the Pacific Crest Trail and Trail 114. This drainage had evidence of previous debris flow activity at two stream locations. The first debris flow activity occurred before the 2006 storm, and the second was more recent and had occurred between 2006 and 2009. Due to the lack of a major debris flow producing event since 2006, this second debris flow most likely occurred during the 2006 storm. 
This debris flow travelled approximately $6,180 \mathrm{~m}$ and was initiated by heavy water flow and in channel landslides.

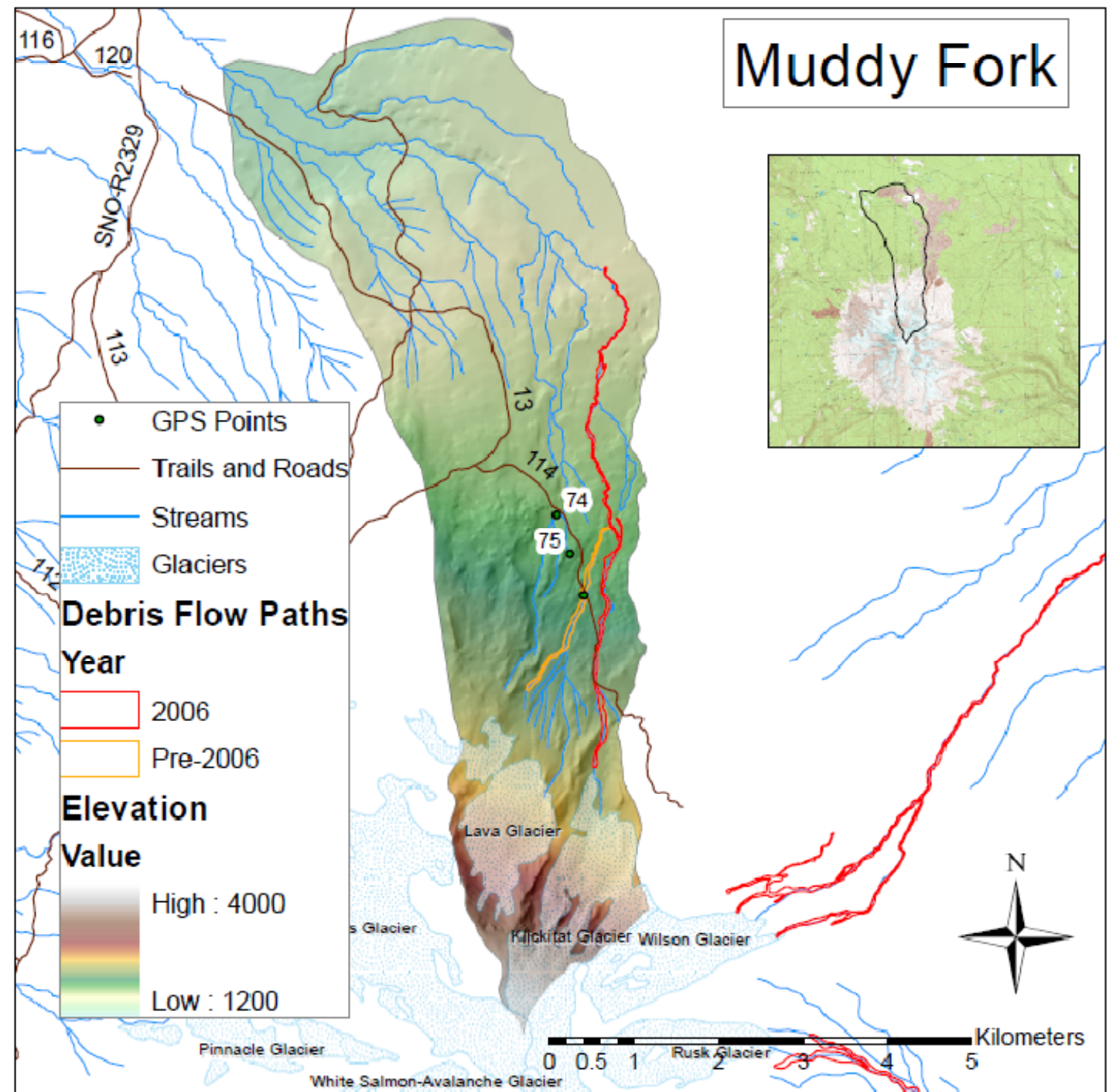

Figure 51: Map of Muddy Fork Drainage. Black numbers are trail and road indicators, black numbers with white halos refer to GPS points. 


\section{Reconnaissance}

Initial reconnaissance was conducted in the summer of 2009. Along Trail 114, several streams are passed. The first indication of debris flow activity was at GPS point 76; here there were sandy mud coated boulders and incision in the sidewalls (Figure 52). At the second stream crossing, deep incision was visible as well as fresh looking scarps upstream (Figure 53). At both stream crossings, vegetation was absent and trail crossings were washed out.

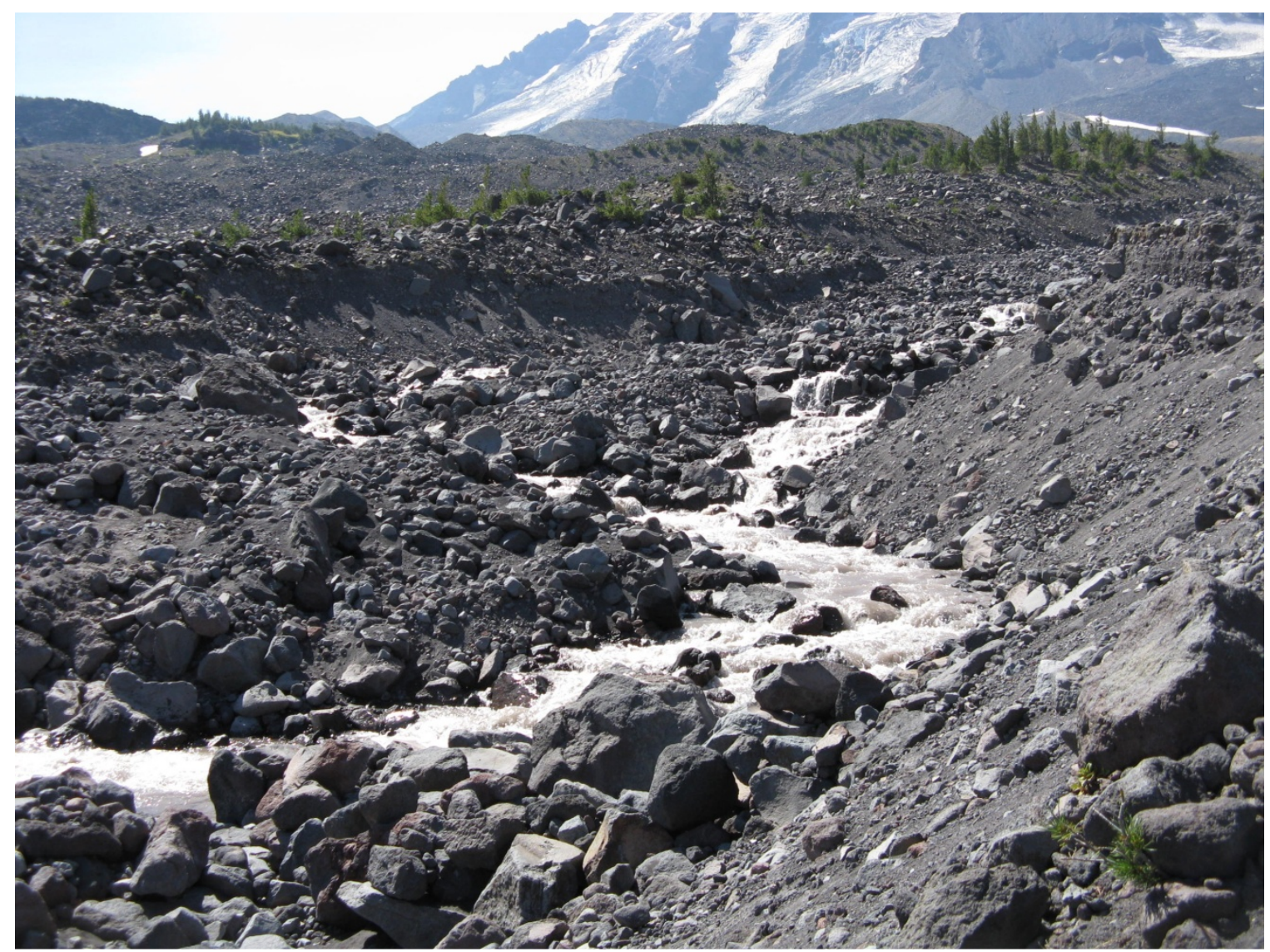

Figure 52: Muddy Fork drainage at GPS point 76. Photo taken during the summer of 2009. 


\section{Initiation Zone}

During the summer of 2009 , the upper Muddy Fork drainage was explored by hiking up Trail 114. In the upper basin area, deep incision was visible in multiple places (Figures 54 \& 55). Scarps along the channel were found in many places and seen in oblique air photos (Figure 56). This debris flows was initiated by heavy water flow and an in channel landslide.

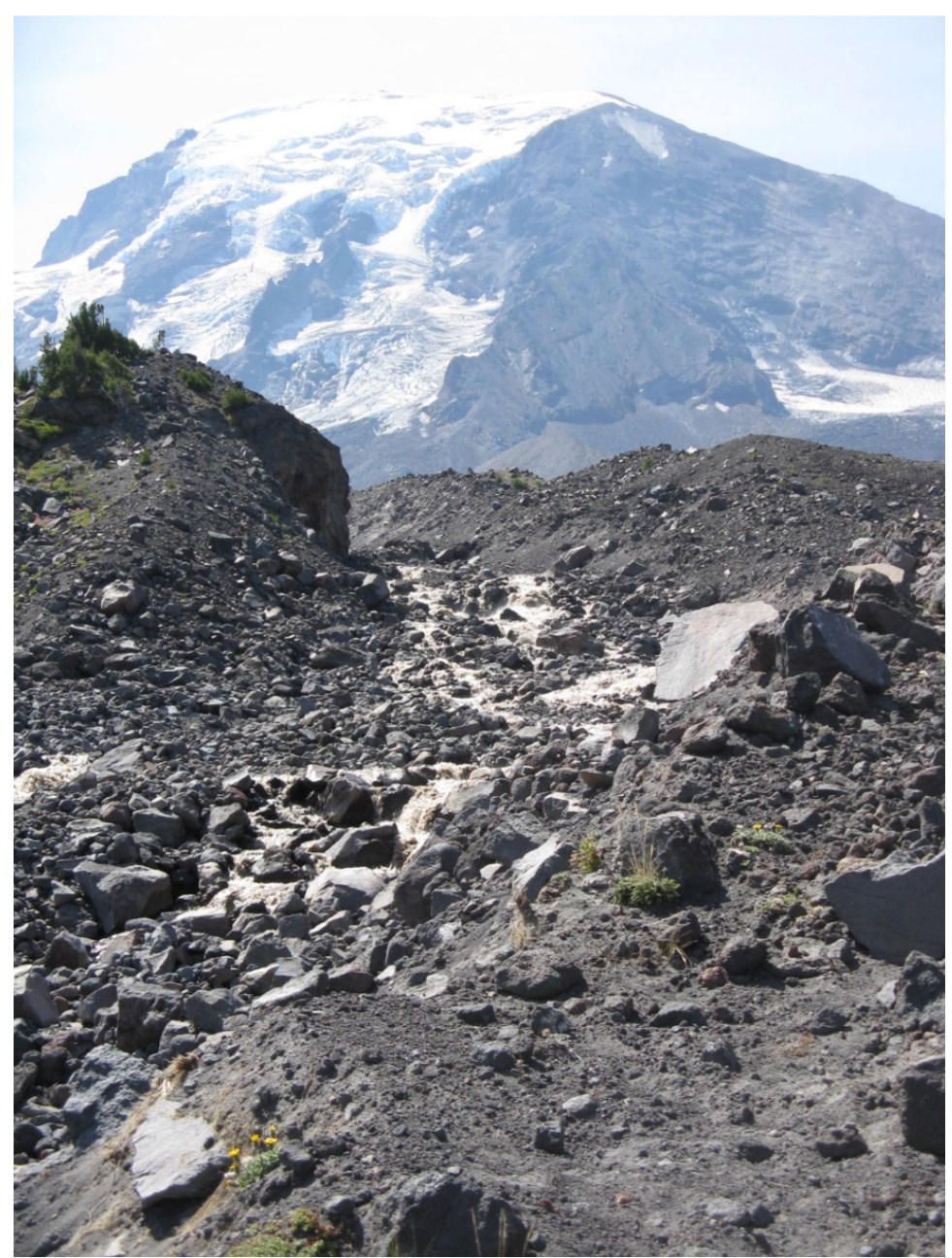

Figure 53: Muddy Fork Drainage at GPS point 76 along Trail 114. Photo taken during the summer of 2009. 
During the summer of 2010, oblique air photos were taken of the upper Muddy Fork drainage. These photos also showed the scarps found in the field. These scarps were on one side of a natural constriction formed by two glacial moraines. This natural constriction is similar to that in the upper drainage of Salt Creek and Adams Creek.

Orthophotos were analyzed in the Muddy Fork Drainage. For the first stream crossing, little difference could be seen in the channel activity for the pre-storm 2006 orthophoto and the 2009 orthophoto. This first debris flow activity most likely occurred before the 2006 storm. The second stream crossing showed several areas of difference between the pre storm 2006 orthophoto and the 2009 orthophoto. This debris flow activity occurred between 2006 and 2009.

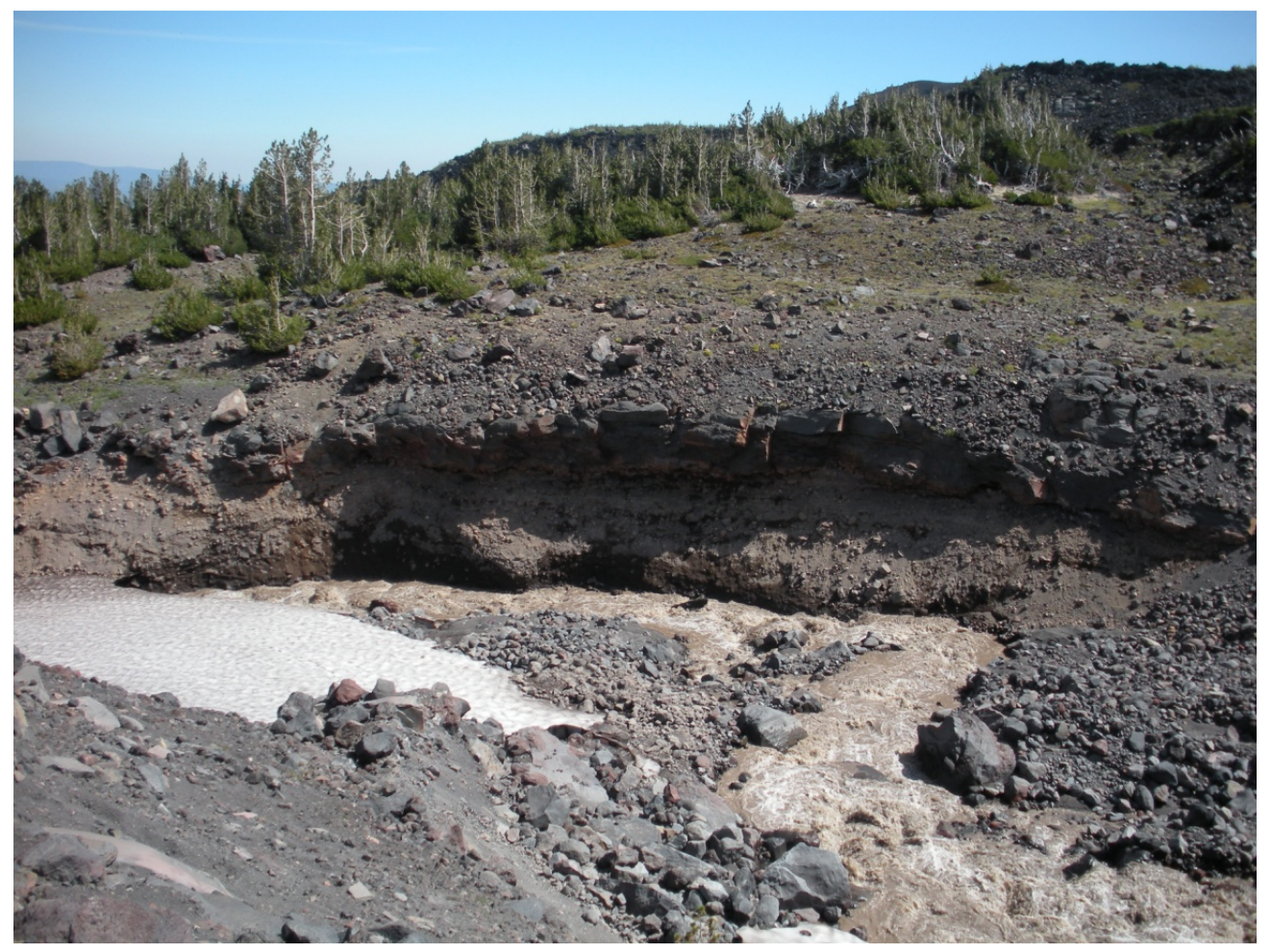

Figure 54: Muddy Fork Drainage with channel incision. Photo taken during the summer of 2009. 


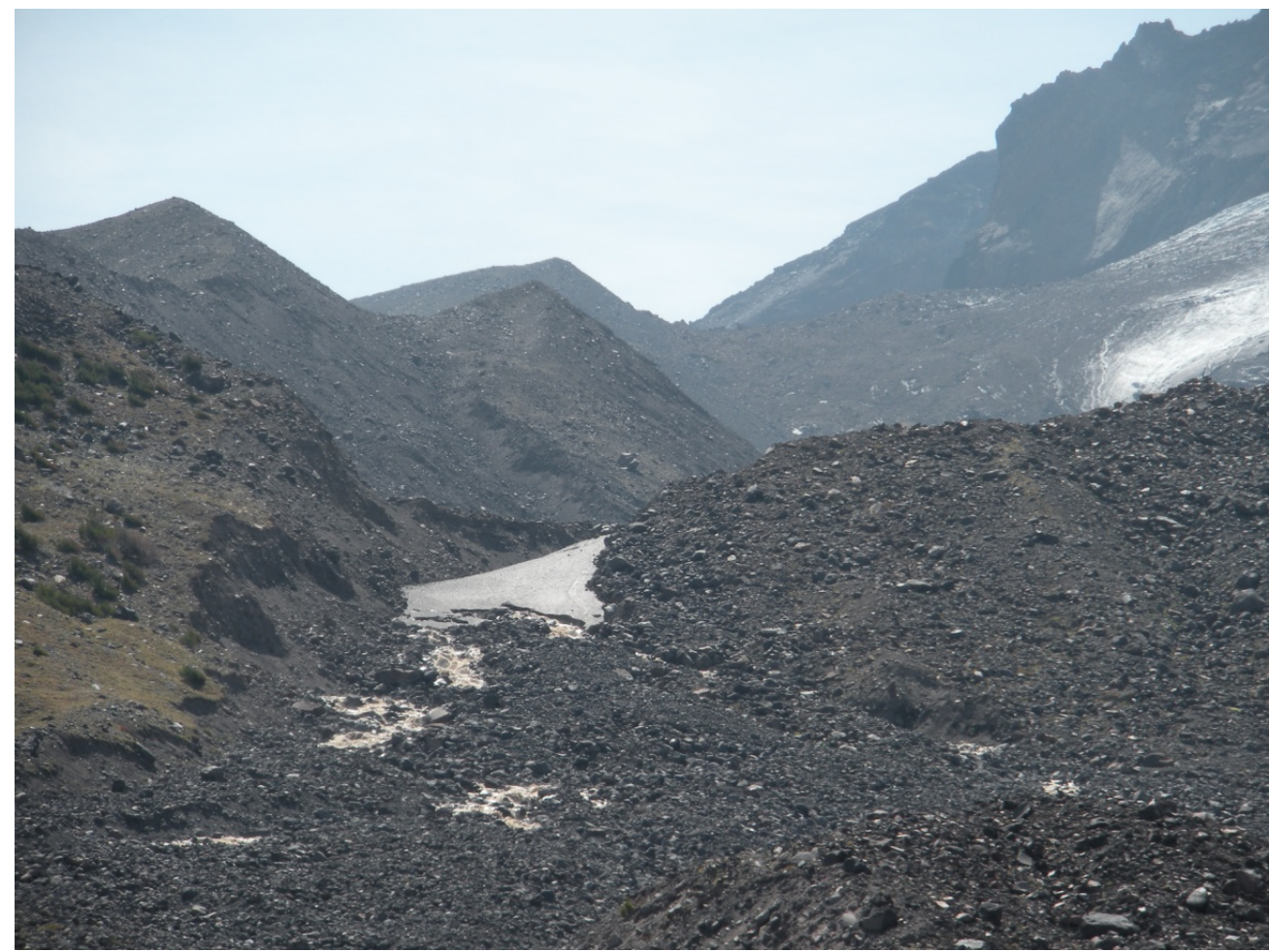

Figure 55: Upper Muddy Fork Drainage, incision visible looking through the gap in the moraine in the middle of the photo. Photo taken during the summer of 2009.

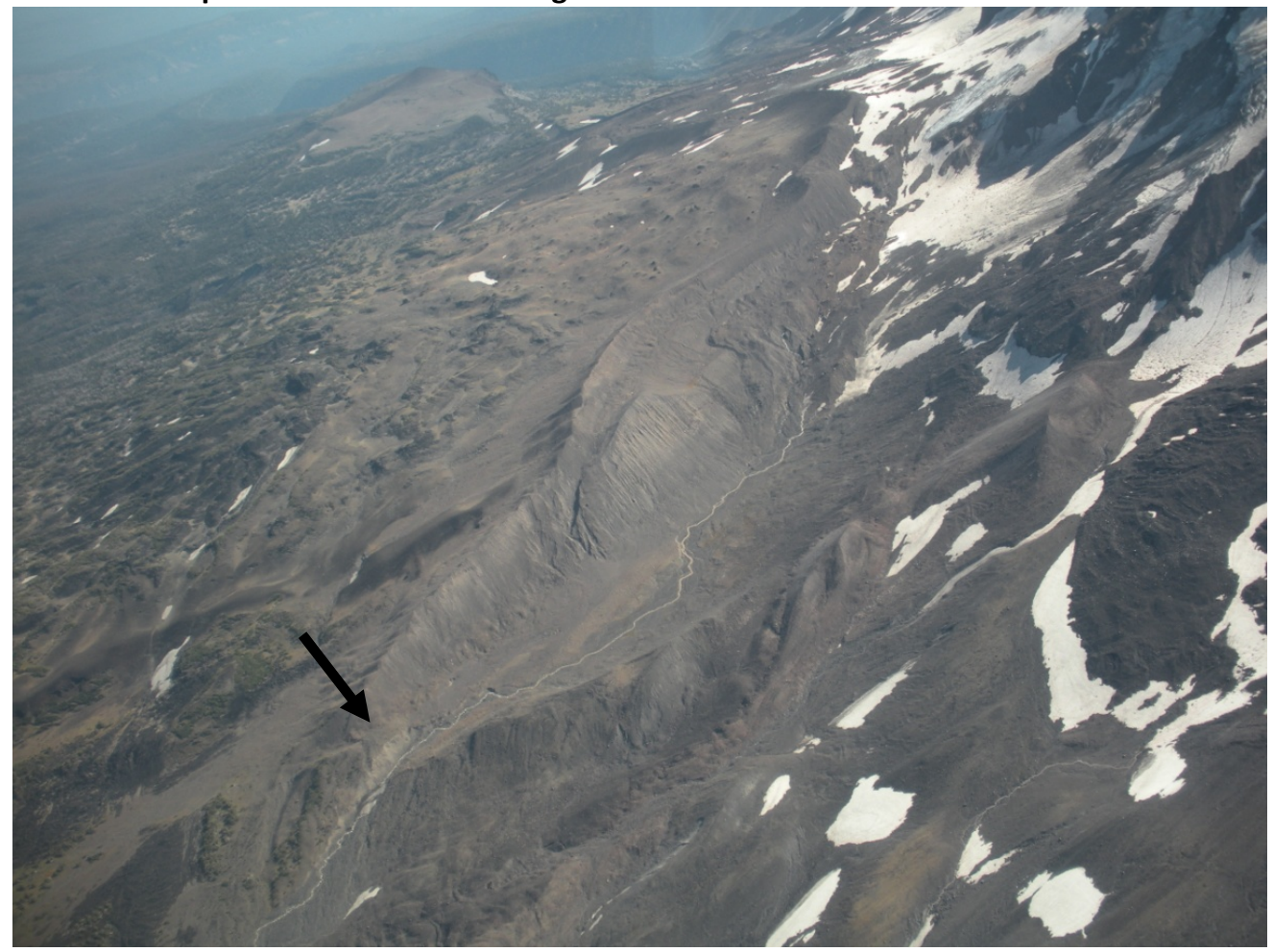

Figure 56: Oblique air photo of the Muddy Fork drainage. Landslide scarp visible at black arrow. Photo taken September $30^{\text {th }}, 2010$. 


\section{Sample Collection \& Sieve Results}

Due to limited field season, a large study area and difficulty of access samples were not collected for the Muddy Fork Drainage.

Table 23: Muddy Fork Drainage Basin attributes

\begin{tabular}{|c|c|c|c|c|}
\hline \multicolumn{2}{|l|}{ Factor } & $\underline{\text { Value }}$ & $\begin{array}{l}\text { All Geologic } \\
\text { Units }\end{array}$ & $\begin{array}{l}\text { \% of Upper } \\
\text { Basin }\end{array}$ \\
\hline \multicolumn{2}{|c|}{ Elevation of initiation zone (m) } & 2200 & Ice & \\
\hline \multicolumn{2}{|c|}{ Total Basin Area $\left(\mathrm{m}^{2}\right)$} & 31396120 & Glacier & 49 \\
\hline \multicolumn{2}{|l|}{ Upper Basin Area $\left(\mathrm{m}^{2}\right)$} & 7222600 & Dacite & \\
\hline \multicolumn{2}{|c|}{ Distance from the glacier $(\mathrm{m})$} & 0 & Qvd(a) & 0 \\
\hline \multicolumn{2}{|l|}{ Glacier Area $\left(\mathrm{m}^{2}\right)$} & 3527560 & Basalt & \\
\hline \multicolumn{2}{|c|}{ Surface Connection to the Glacier } & Yes & Qvb(gt) & 0 \\
\hline \multicolumn{2}{|c|}{ Highest Elevation of the Basin (m) } & 3660 & Qvb(ri) & 0 \\
\hline \multicolumn{2}{|c|}{ Basin Height $(\mathrm{m})$} & 2330 & Qvb(rb) & 0 \\
\hline \multicolumn{2}{|l|}{ Upper Basin Length (m) } & 4830 & Andesite & \\
\hline \multicolumn{2}{|l|}{ Upper Basin Gradient } & 0.62 & Qva(a) & 14 \\
\hline \multicolumn{2}{|l|}{ Percent Vegetation } & 0 & Qva(ah) & 0 \\
\hline \multicolumn{2}{|l|}{ Percent Steep Slopes } & 20 & Qva(hb) & 0 \\
\hline \multicolumn{2}{|c|}{ Melton's Ruggedness number } & 0.42 & Qva(sb) & 0 \\
\hline \multicolumn{2}{|c|}{ Grain Size Average Sand Percent } & $\mathrm{N} / \mathrm{A}$ & Qvba(Im) & 0 \\
\hline \multicolumn{2}{|c|}{ Average Annual Precipitation (m) } & 2.2 & Glacial Drift & \\
\hline \multicolumn{2}{|c|}{ Glacier Area Lost From 1904-2006 $\left(\mathrm{m}^{2}\right)$} & 1390000 & Qad & 36 \\
\hline \multicolumn{2}{|c|}{ Percent Glacier area lost 1904-2006 } & -53.5 & Qad(md) & 0 \\
\hline \multicolumn{2}{|c|}{ Glacier Area Lost From 1998-2006 $\left(\mathrm{m}^{2}\right)$} & 630000 & Volcaniclastic & \\
\hline & Qvc(a) & 0 \\
\hline \multicolumn{3}{|c|}{ Major Geologic Units $\quad$ \% of Upper Basin } & & \\
\hline Ice & \multicolumn{2}{|l|}{49} & Bedrock vs. & \% of Upper \\
\hline Dacite & \multicolumn{2}{|l|}{0} & Unconsolidated & Basin \\
\hline Basalt & \multicolumn{2}{|l|}{0} & \multirow{2}{*}{$\begin{array}{l}\text { Basalt, Andesite, } \\
\text { Dacite }\end{array}$} & \\
\hline Andesite & \multicolumn{2}{|l|}{15} & & 15 \\
\hline Glacial Drift & 36 & & \multirow{2}{*}{$\begin{array}{l}\text { Volcaniclastic, } \\
\text { Glacial Drift }\end{array}$} & \\
\hline Volcaniclastic & 0 & & & 36 \\
\hline
\end{tabular}

\section{Basin Attributes}

The elevation of the Muddy Fork Initiation Zone is about 2,200 m, on a deposit geologically mapped as Quaternary Glacial Drift. The total basin area is $31.4 \mathrm{~km}^{2}$, and the upper basin is $7.2 \mathrm{~km}^{2}$. The distance from the stream beginning to the glacier is zero meters and $3.5 \mathrm{~km}^{2}$, or $49 \%$, of the upper basin is covered in glaciers. The stream is 
directly connected to the glacier. The highest elevation of the basin is $3,660 \mathrm{~m}$, the basin height is $2,330 \mathrm{~m}$, and the basin length is $4,830 \mathrm{~m}$. The gradient of the upper basin is $0.62,0 \%$ of the upper basin is vegetated and $20 \%$ are steep slopes. MRN is calculated as 0.42 , and the average annual precipitation is $2.2 \mathrm{~m}$.

\subsubsection{Riley Creek}

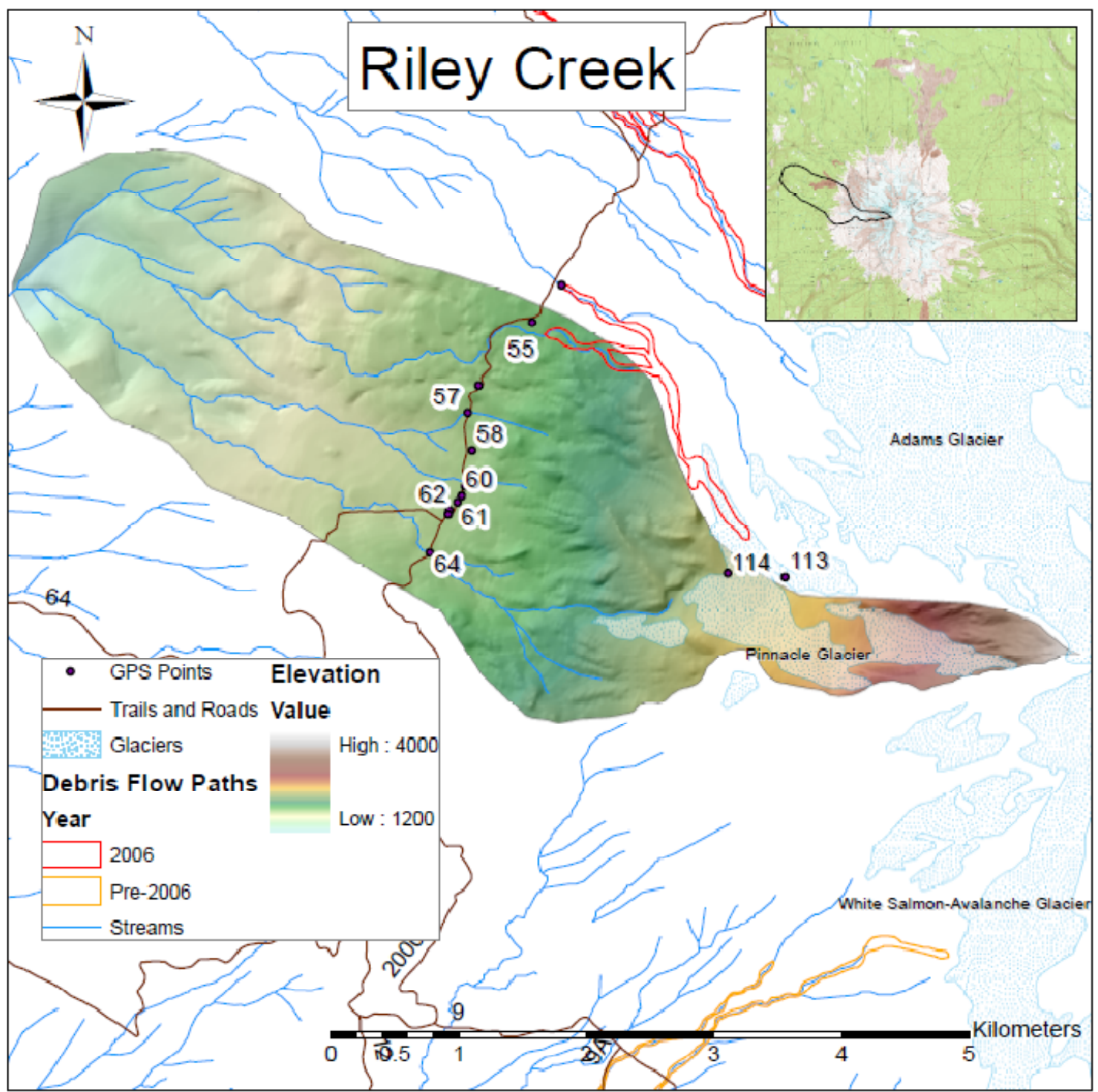

Figure 57: Map of Riley Creek Drainage. Black numbers are trail and road indicators, black numbers with white halos refer to GPS points. 
Riley Creek is located on the northwest side of Mt. Adams (Figure 57). This

drainage is accessible from Trails 64 and 9 or the Pacific Crest Trail. This drainage is fairly secluded and less popular for outdoor recreation. Debris flow activity was observed for this drainage in one location. However, this debris flow deposit, when traced up the mountain, was found to have originated in the Lewis Creek Drainage. Therefore, no debris flows were attributed to Riley Creek. Other creeks in this drainage had no evidence of past debris flows, and no evidence was observed in the oblique air photos or orthophotos.

\section{Reconnaissance}

Initial reconnaissance was conducted in the summer of 2009. Following Trail 9 in the Riley Creek Drainage, several small creeks were passed. Most of these streams were small with normal stream activity and erosion taking place (Figure 58). One stream was slightly larger with a few downed trees across the channel, but this drainage still did not show evidence of incision or debris flow activity (Figure 59). Vegetation was abundant in the sidewalls of all creeks. At GPS point 55, a sand and boulder deposit was found (Figure 60). This deposit resembled a fanned out debris flow deposit and housed beaten looking logs (Figure 61).

Therefore, because this project is emphasizing initiation mechanisms, this drainage was determined to not have initiated a 2006 debris flow but to have pre-2006 debris flow deposits. 


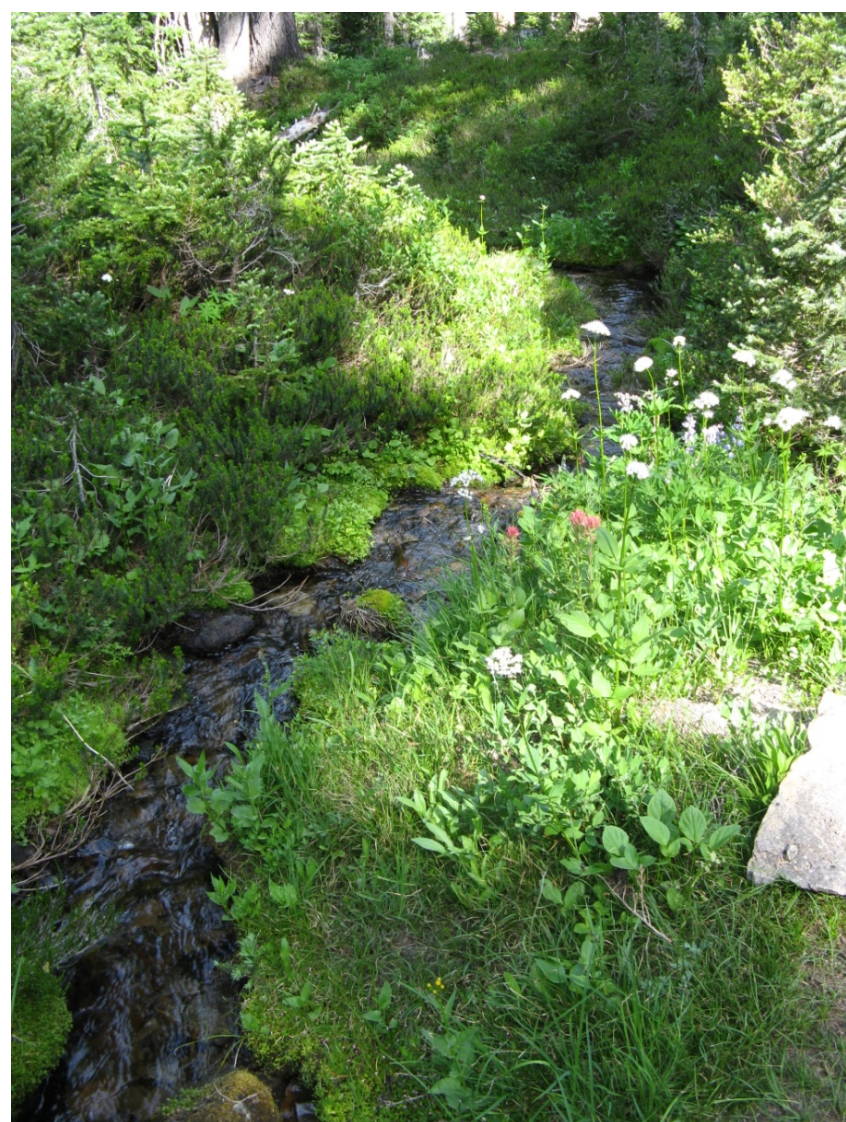

Figure 58: Small stream in the Riley Creek Drainage. Photo taken during the summer of 2009.

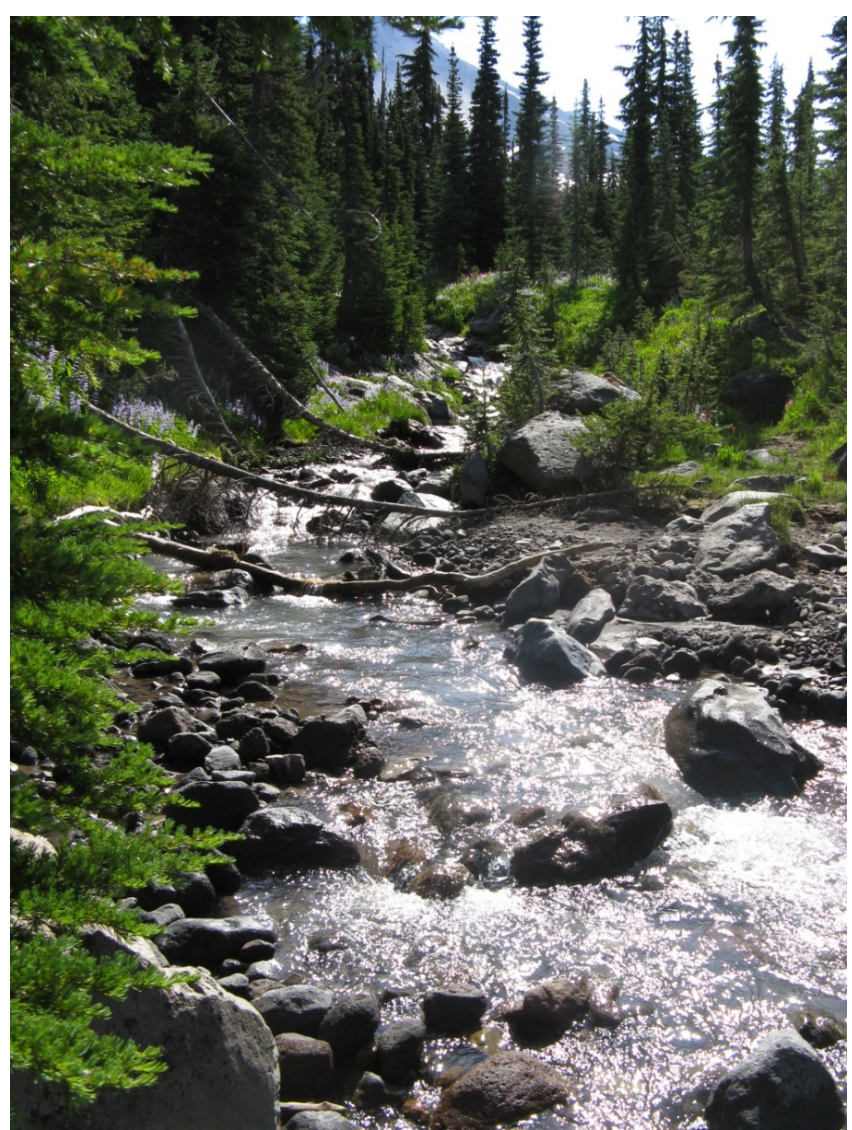

Figure 59: Riley Creek drainage at the crossing with the Pacific Crest Trail. Photo taken during the summer of 2009. 


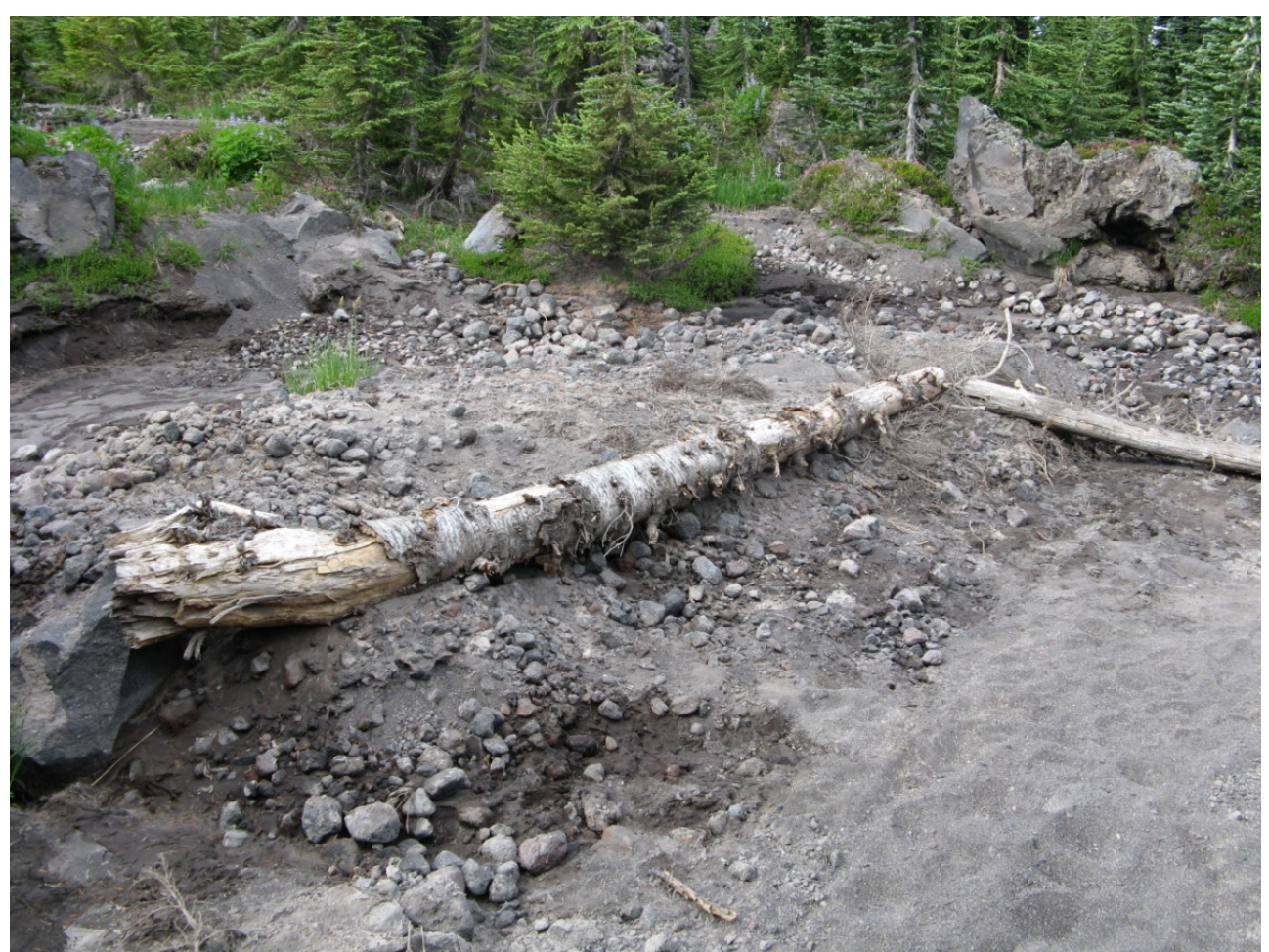

Figure 60: Ragged downed log in a debris flow deposit in the Riley Creek Drainage. This deposit came from a debris flow that initiated in the Lewis Creek Drainage. Photo taken during the summer of 2009.

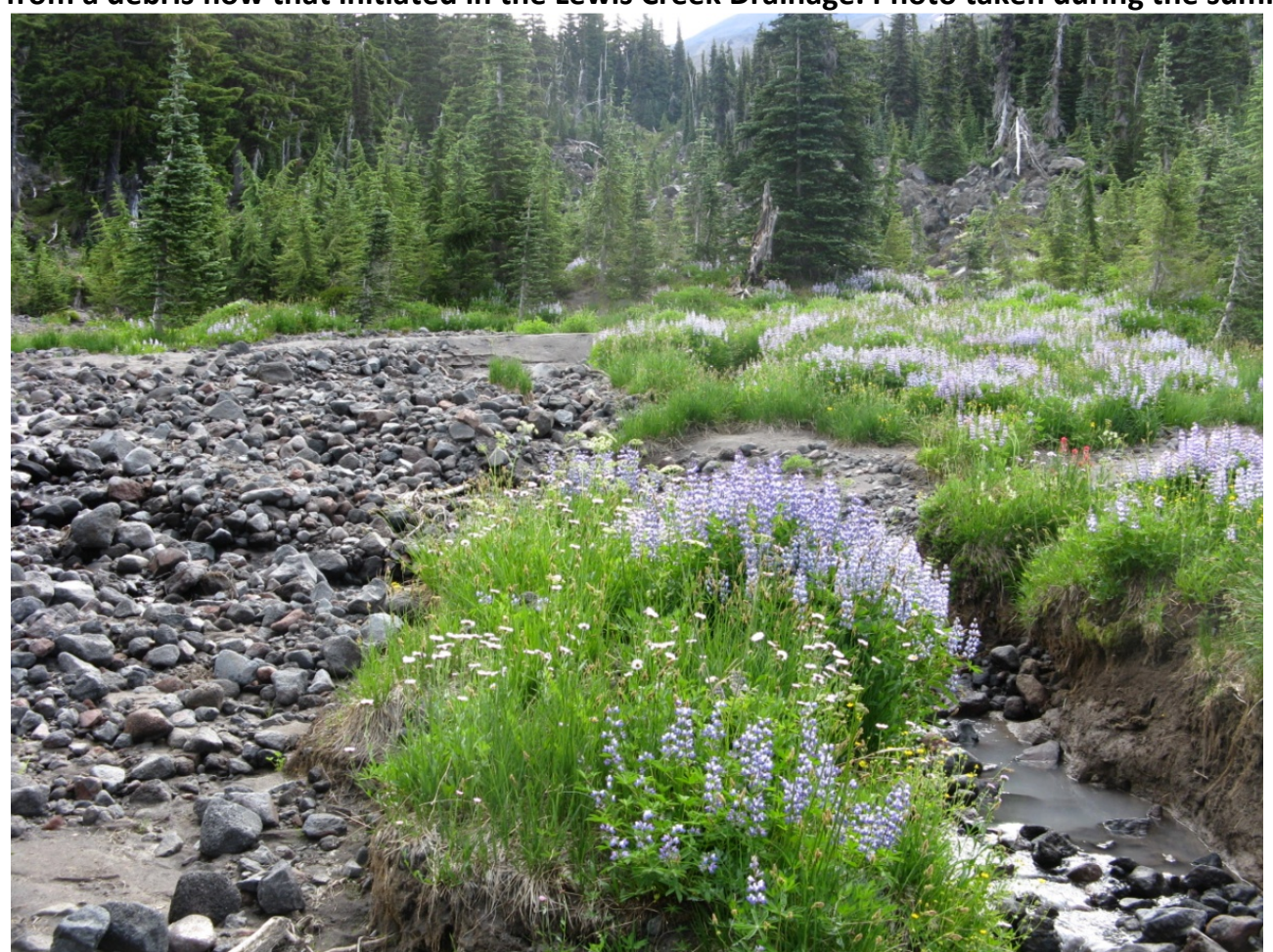

Figure 61: Debris flow deposit in the Riley Creek Drainage. This deposit came from a debris flow that initiated in the Lewis Creek Drainage. Photo taken during the summer of 2009. 


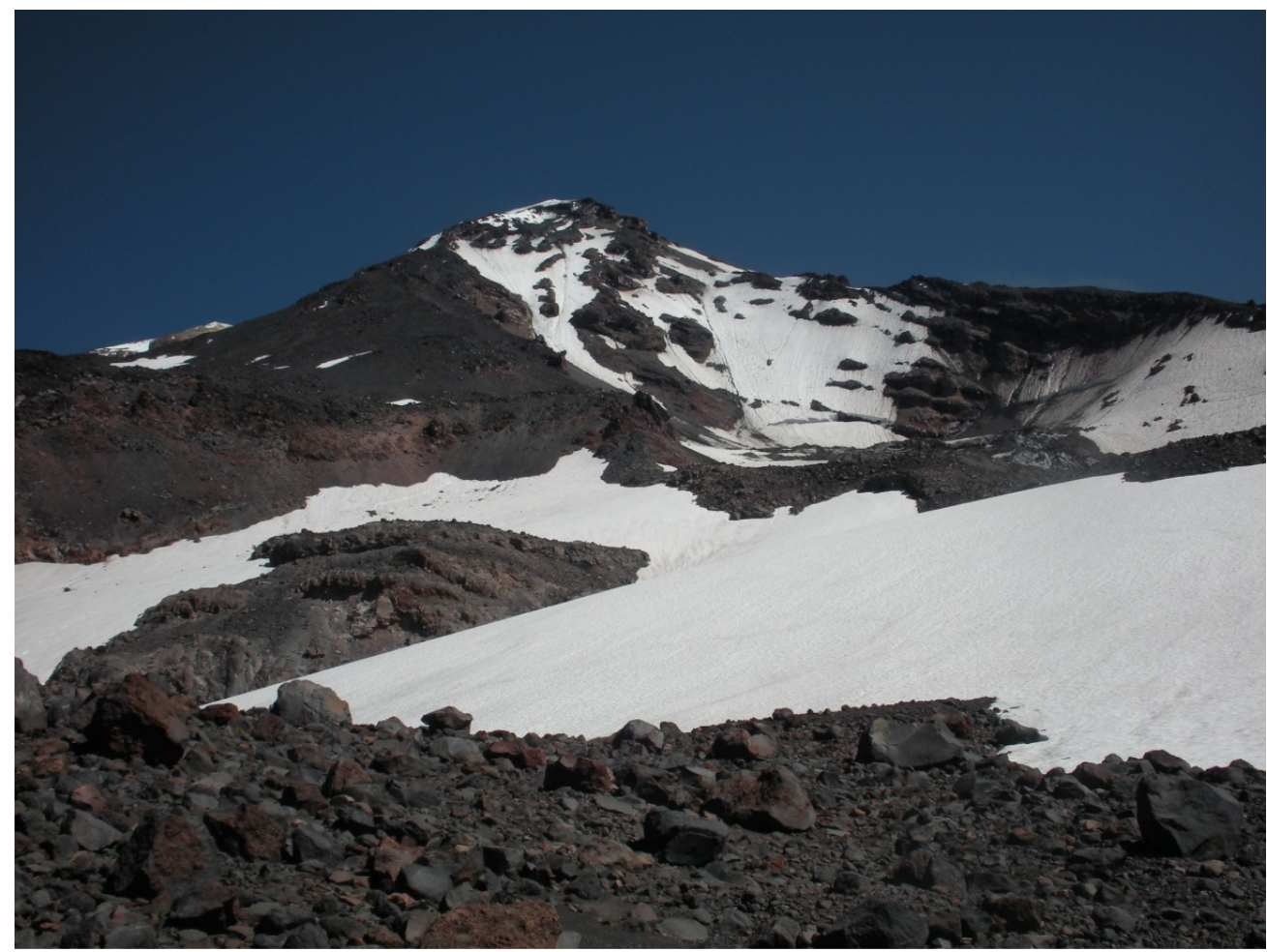

Figure 62: Photo of the upper Riley Creek Drainage. Photo taken during the summer of 2009.

\section{Initiation Zone}

During the summer of 2010 the upper Riley Creek Drainage was explored by hiking a ridge between the Adams Creek and Lewis Creek drainages, across the upper Lewis Creek Basin, into the Upper Riley Creek Basin and then down the Lewis Creek drainage. Only a small part of the upper Riley Creek Basin was surveyed (Figure 62), but no initiation zones were discovered. Upon hiking down the Lewis Creek Basin, the debris flow deposit found in the lower Riley Creek drainage was a result of the Lewis Creek Debris Flow surging over the ridge between the drainages in at least one location and depositing in a flat area of the Riley Creek Drainage. 


\section{Sample Collection}

Three soil samples for Riley Creek were taken from GPS point 113. This location was chosen because the elevation was similar to that of other debris flow initiation zones. It was taken in an area geologically mapped as Quaternary Glacial Drift (Qad) (Department of Natural Resources, 2005).

Sieve Results

Samples from Riley Creek Drainage are presented in Table 24 along with average values. Bulk density was measured at $1.5 \mathrm{~g} / \mathrm{cm}^{3}$, and the sample contained $37 \%$ gravel, $61 \%$ sand and $1 \%$ fines.

Table 24: Riley Creek sieve results, sample 113 subsets 1, 2 and 3. See Table 1 for exact size definitions. Bottom row holds the average values.

\begin{tabular}{|c|c|c|c|c|c|c|c|}
\hline \multirow{2}{*}{$\#$} & \multirow{2}{*}{$\begin{array}{c}\text { Bulk Density } \\
(\mathrm{g} / \mathrm{cm} 3)\end{array}$} & Gravel & Sand & \multicolumn{3}{|c|}{ Sand Distribution } & \multirow{2}{*}{$\begin{array}{c}\text { Silt \& } \\
\text { Clay }\end{array}$} \\
\cline { 5 - 8 } & & & & Coarse Sand & Medium Sand & Fine Sand & \\
\hline 1 & 1.6 & 23 & 75 & 43 & 19 & 12 & 3.3 \\
2 & 1.8 & 8 & 85 & 46 & 25 & 14 & 7.6 \\
3 & 1.4 & 7 & 89 & 47 & 35 & 7 & 3.5 \\
\hline $\boldsymbol{x}$ & $1.6 \pm .2$ & $13 \pm 8.9$ & $83 \pm 7.4$ & $45 \pm 1.9$ & $27 \pm 8.1$ & $11 \pm 3.5$ & $4.8 \pm 2.4$ \\
\hline
\end{tabular}

\section{Basin Attributes}

The total Riley Creek Basin area is $14.9 \mathrm{~km}^{2}$, and the upper basin is $6.5 \mathrm{~km}^{2}$. The distance from the stream beginning to the glacier is zero meters and $1.1 \mathrm{~km}^{2}$, or $17 \%$, of the upper basin is covered in glaciers. The stream is directly connected to the glacier. The highest elevation of the basin is 3,640 m, the basin height is $2,450 \mathrm{~m}$, and the basin length is $5,820 \mathrm{~m}$. The gradient of the upper basin is $0.34,28 \%$ of the upper basin is 
vegetated and $10 \%$ are steep slopes. MRN is calculated as 0.63 , and the average annual precipitation is $3.2 \mathrm{~m}$.

Table 25: Riley Creek Drainage Basin attributes

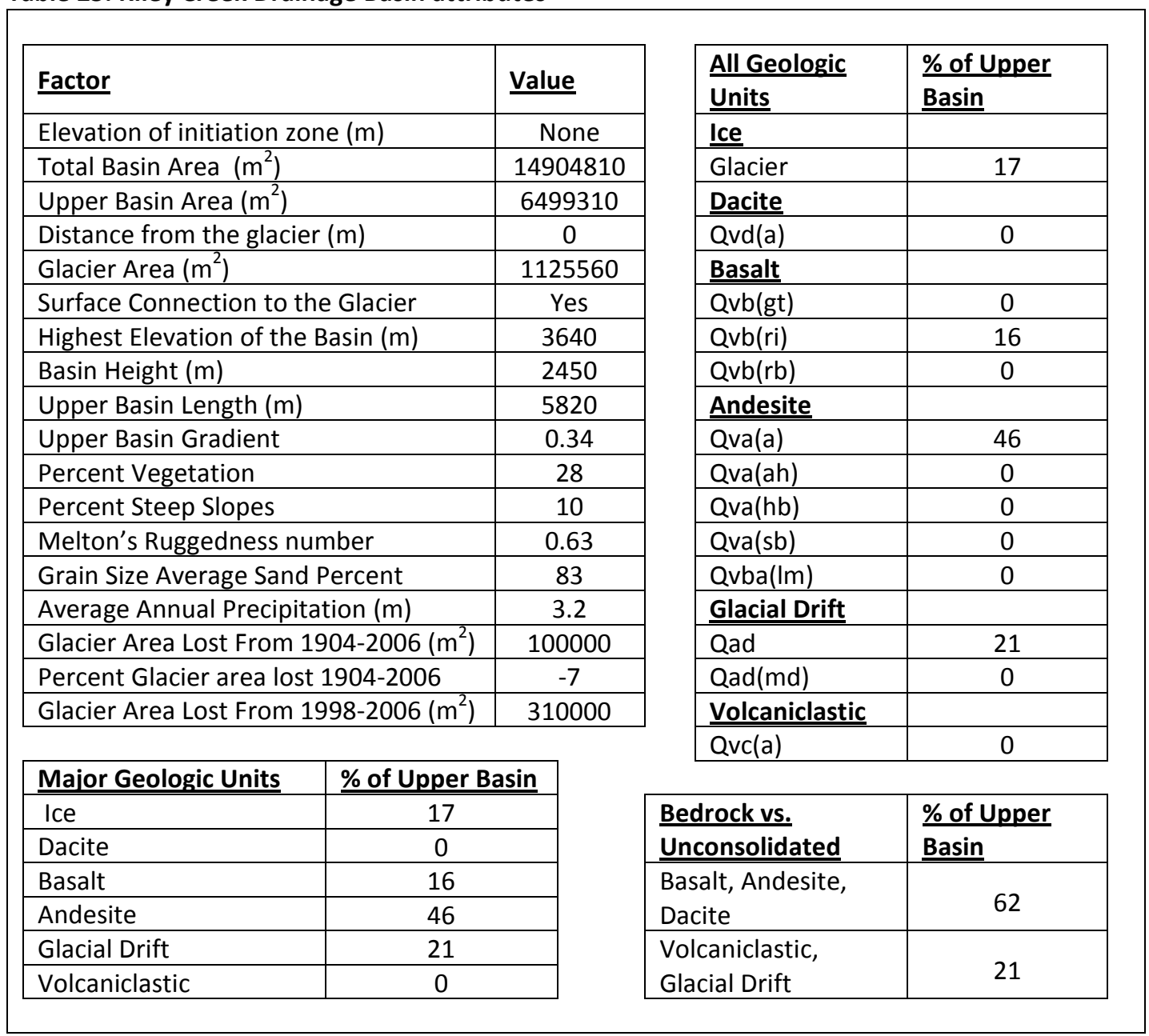

\subsubsection{Rusk Creek}

Rusk Creek is located on the east side of Mt. Adams (Figure 63). In 2006 this drainage experienced a debris flow that traveled approximately 5,400 m where it joined the Big Muddy Creek Debris Flow and continued down-slope. Similar to the Big Muddy Debris Flow, this debris flow was a headless debris flow. Big Muddy Creek is joined by 
Rusk Creek at an elevation of 1,300 m. The combined deposit of these two debris flows extends to an elevation of about 1,200 m (Darryl Lloyd, Personal Communication 2007).

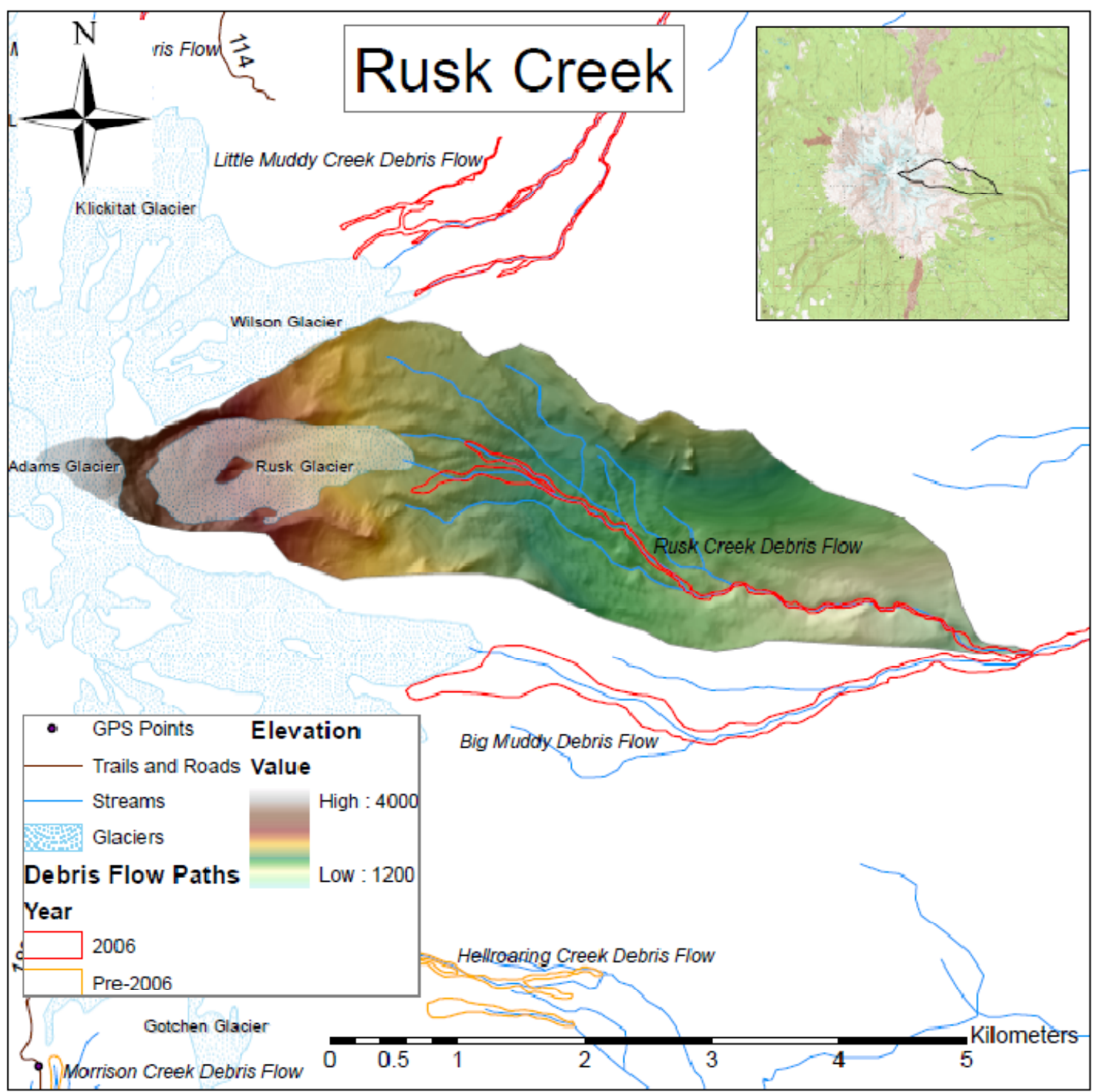

Figure 63: Map of Rusk Creek Drainage. Black numbers are trail and road indicators, black numbers with white halos refer to GPS points.

\section{Reconnaissance}

The reconnaissance for Rusk Creek was conducted in 2007 by Darryl Lloyd. Further investigation was not conducted due to limited field season and a large study area. 
Based on the photos taken by Darryl Lloyd in 2007, this debris flow initiated with a coalescence of several channels eroded into avalanche deposits and glacial drift. These channels are visibly incised, and no vegetation remained on the channel sidewalls (Figures 64 \& 65).

\section{Initiation Zone}

Oblique air photos were taken during the summer of 2010 of the Rusk Creek

Debris Flow initiation zone. Here, the coalescence of eroded channels is visible as well as incision in the channel (Figure 66).

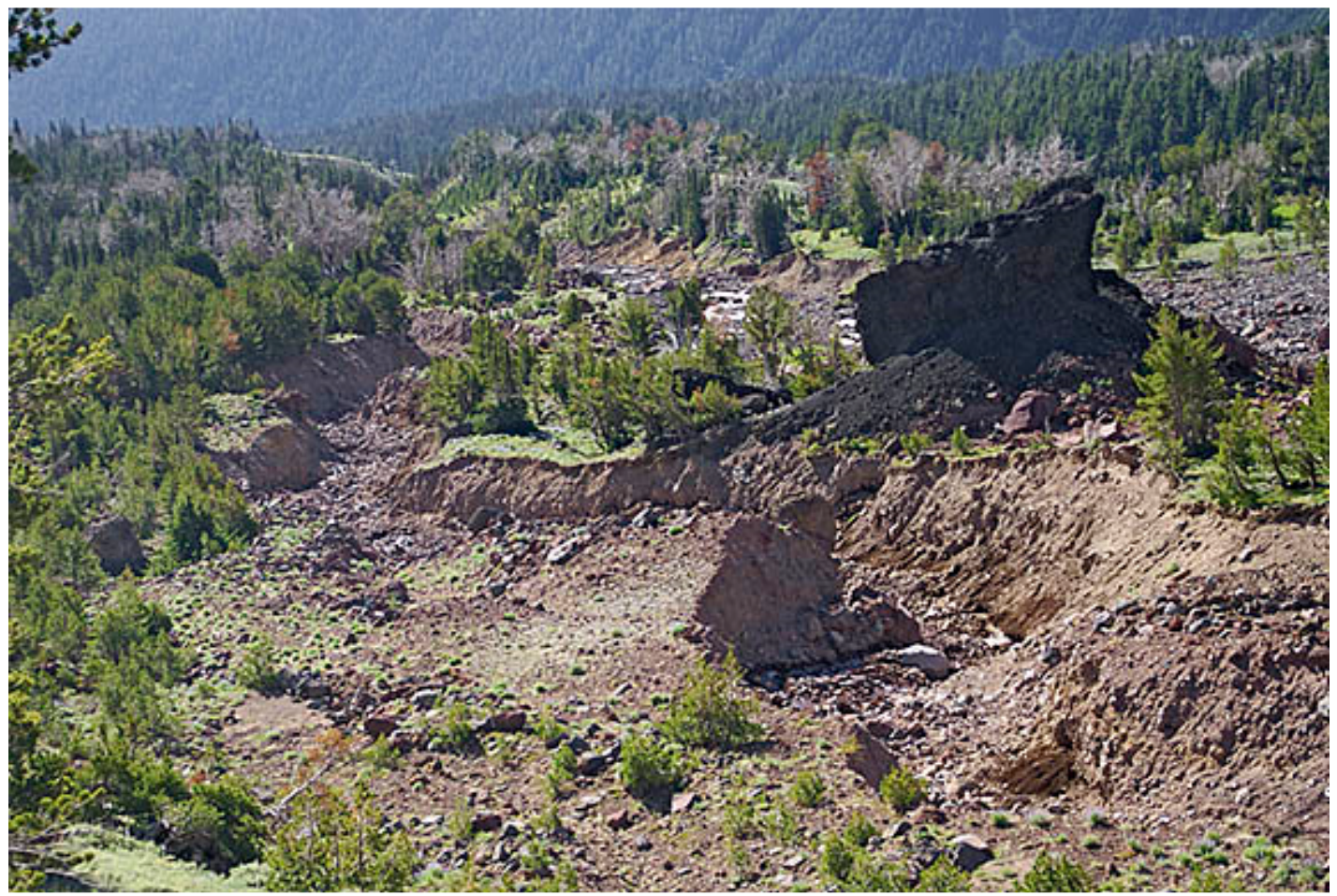

Figure 64: Several channels of debris flow action at 2,073 m elevation in the Rusk Creek Drainage. Photo taken by Darryl Lloyd 7/23/2007. 


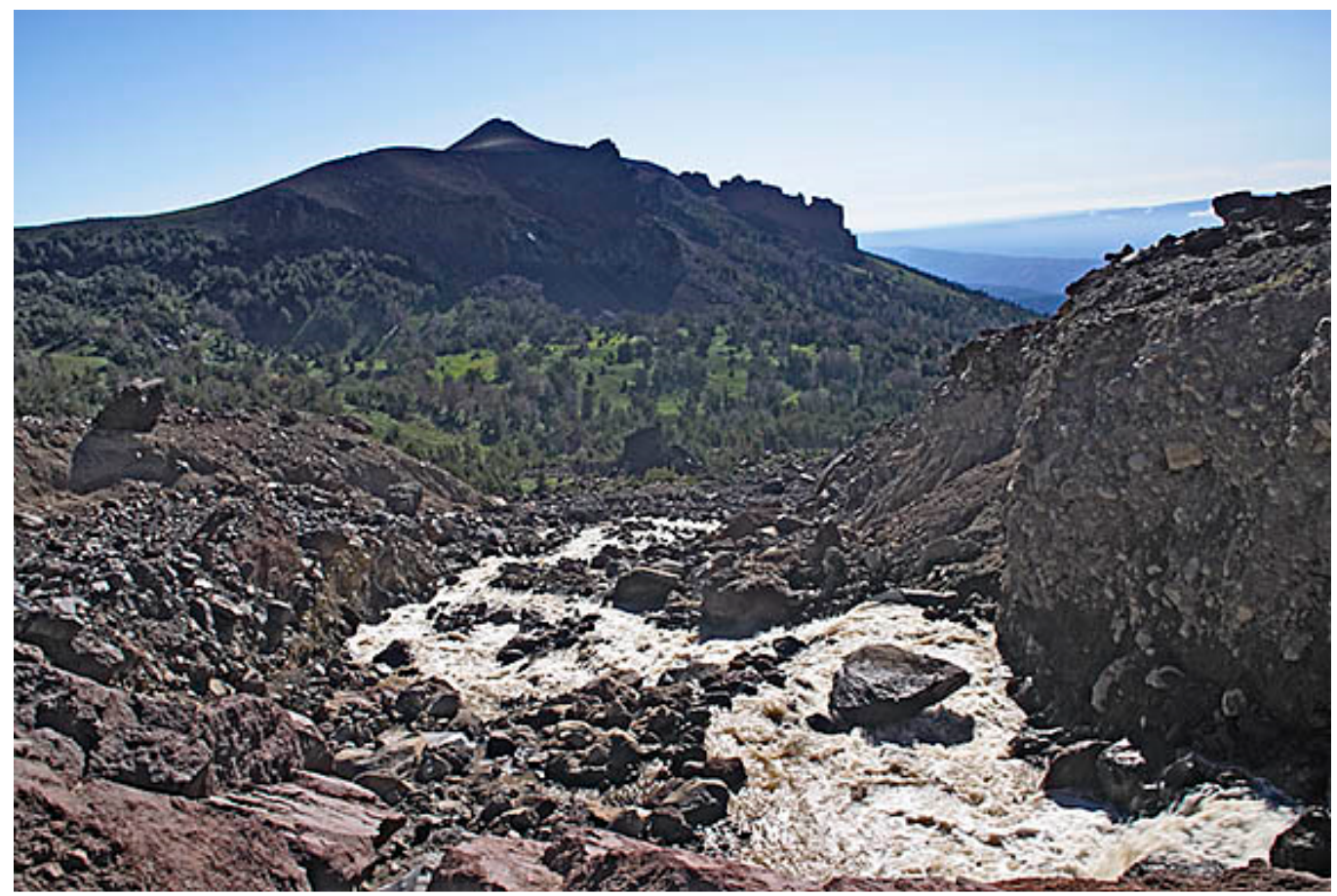

Figure 65: Middle branch of Rusk Creek at 2,100 m in elevation. Photo taken by Darryl Lloyd on July 23, 2007.

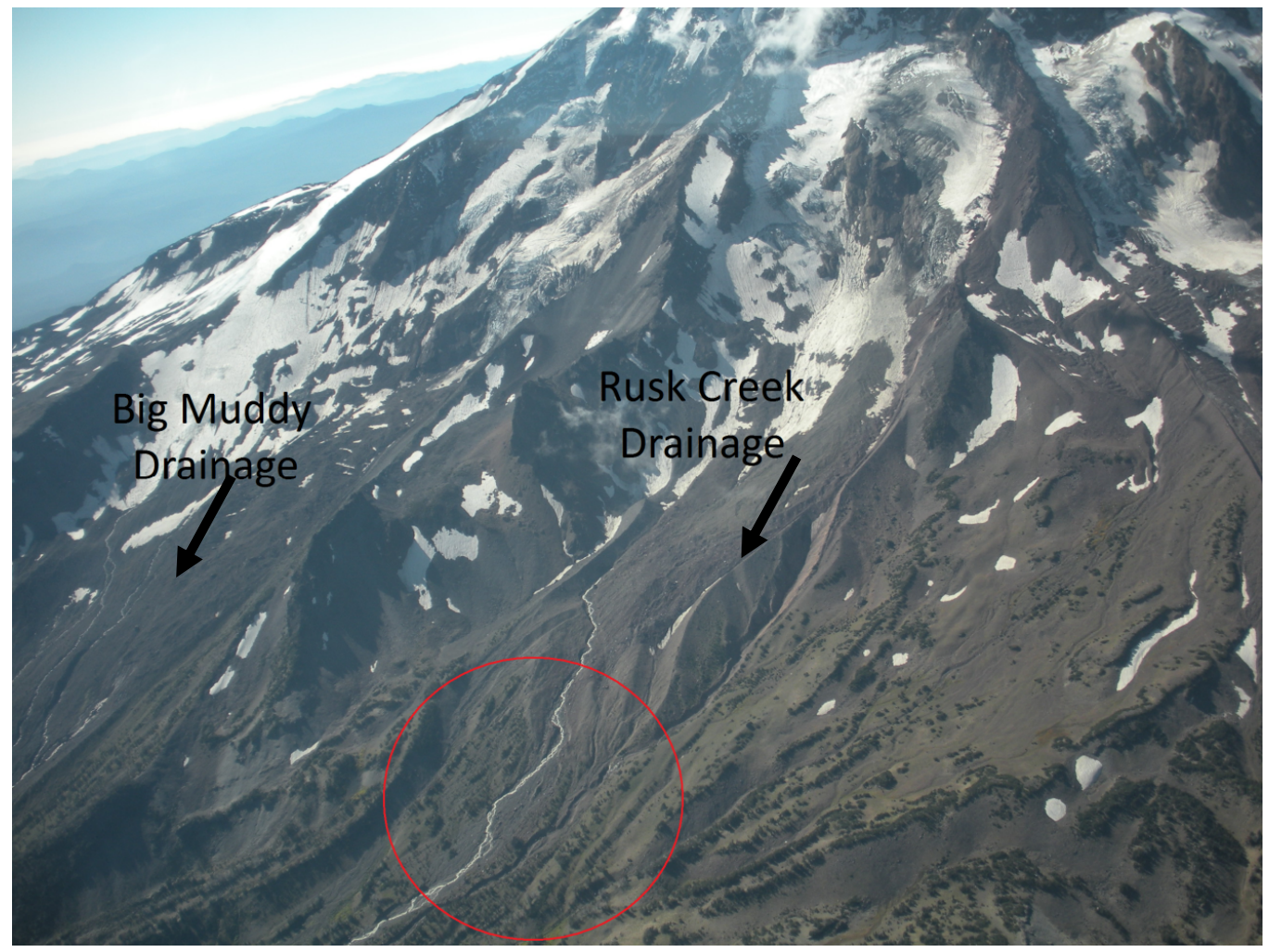

Figure 66: Oblique air photo of the upper Rusk Creek Drainage. The red circle indicates several eroded channels that coalesce at a lower elevation. Black arrows point down slope. Photo taken September $30^{\text {th }}, 2010$. 


\section{Sample Collection \& Sieve Results}

Samples were not collected for the Rusk Creek Drainage due to limited field season and a large study area.

Table 26: Rusk Creek Drainage Basin attributes

\begin{tabular}{|c|c|c|c|c|}
\hline \multicolumn{2}{|l|}{ Factor } & $\underline{\text { Value }}$ & $\begin{array}{l}\text { All Geologic } \\
\text { Units }\end{array}$ & $\begin{array}{l}\text { \% of Upper } \\
\text { Basin }\end{array}$ \\
\hline \multicolumn{2}{|c|}{ Elevation of initiation zone (m) } & 2220 & Ice & \\
\hline \multicolumn{2}{|c|}{ Total Basin Area $\left(\mathrm{m}^{2}\right)$} & 9972720 & Glacier & 26 \\
\hline \multicolumn{2}{|l|}{ Upper Basin Area $\left(\mathrm{m}^{2}\right)$} & 5137700 & Dacite & \\
\hline \multicolumn{2}{|c|}{ Distance from the glacier $(\mathrm{m})$} & 0 & Qvd(a) & 9 \\
\hline \multicolumn{2}{|l|}{ Glacier Area $\left(\mathrm{m}^{2}\right)$} & 1311880 & Basalt & \\
\hline \multicolumn{2}{|c|}{ Surface Connection to the Glacier } & Yes & Qvb(gt) & 1 \\
\hline \multicolumn{2}{|c|}{ Highest Elevation of the Basin (m) } & 3680 & Qvb(ri) & 0 \\
\hline \multicolumn{2}{|c|}{ Basin Height $(\mathrm{m})$} & 2360 & $\mathrm{Qvb}(\mathrm{rb})$ & 0 \\
\hline \multicolumn{2}{|l|}{ Upper Basin Length (m) } & 4450 & Andesite & \\
\hline \multicolumn{2}{|l|}{ Upper Basin Gradient } & 0.40 & Qva(a) & 18 \\
\hline \multicolumn{2}{|l|}{ Percent Vegetation } & 9 & Qva(ah) & 0 \\
\hline \multicolumn{2}{|l|}{ Percent Steep Slopes } & 25 & Qva(hb) & 0 \\
\hline \multicolumn{2}{|c|}{ Melton's Ruggedness number } & 0.75 & Qva(sb) & 0 \\
\hline \multicolumn{2}{|c|}{ Grain Size Average Sand Percent } & $\mathrm{N} / \mathrm{A}$ & Qvba(Im) & 0 \\
\hline \multicolumn{2}{|c|}{ Average Annual Precipitation (m) } & 1.6 & Glacial Drift & \\
\hline \multicolumn{2}{|c|}{ Glacier Area Lost From 1904-2006 (m²) } & 440000 & Qad & 44 \\
\hline \multicolumn{2}{|c|}{ Percent Glacier area lost 1904-2006 } & -23 & Qad(md) & 0 \\
\hline \multicolumn{2}{|c|}{ Glacier Area Lost From 1998-2006 $\left(\mathrm{m}^{2}\right)$} & 230000 & Volcaniclastic & \\
\hline & Qvc(a) & 2 \\
\hline Major Geologic Units & \multicolumn{2}{|c|}{ \% of Upper Basin } & & \\
\hline Ice & \multicolumn{2}{|c|}{26} & \multirow{3}{*}{$\begin{array}{l}\text { Bedrock vs. } \\
\text { Unconsolidated } \\
\text { Basalt Andesite }\end{array}$} & \% of Upper \\
\hline Dacite & \multicolumn{2}{|l|}{9} & & Basin \\
\hline Basalt & \multicolumn{2}{|l|}{1} & & \\
\hline Andesite & \multicolumn{2}{|l|}{18} & $\begin{array}{l}\text { Basalt, Andesite, } \\
\text { Dacite }\end{array}$ & 29 \\
\hline Glacial Drift & 44 & & \multirow{2}{*}{$\begin{array}{l}\text { Volcaniclastic, } \\
\text { Glacial Drift }\end{array}$} & \\
\hline Volcaniclastic & 2 & & & 46 \\
\hline
\end{tabular}

\section{Basin Attributes}

The elevation of the Rusk Creek Initiation Zone is about 2,220 m, on a deposit geologically mapped as Quaternary Glacial Drift (Department of Natural Resources, 2005). The total basin area is $10.0 \mathrm{~km}^{2}$, and the upper basin is $5.1 \mathrm{~km}^{2}$. The distance from the stream beginning to the glacier is zero meters, and $1.3 \mathrm{~km}^{2}$, or $26 \%$, of the 
upper basin is covered in glaciers. The stream is directly connected to the glacier. The highest elevation of the basin is $3,680 \mathrm{~m}$, the basin height is $2,360 \mathrm{~m}$, and the basin length is $4,450 \mathrm{~m}$. The gradient of the upper basin is $0.40,9 \%$ of the upper basin is vegetated and $25 \%$ are steep slopes. MRN is calculated as 0.75 , and the average annual precipitation is $1.6 \mathrm{~m}$.

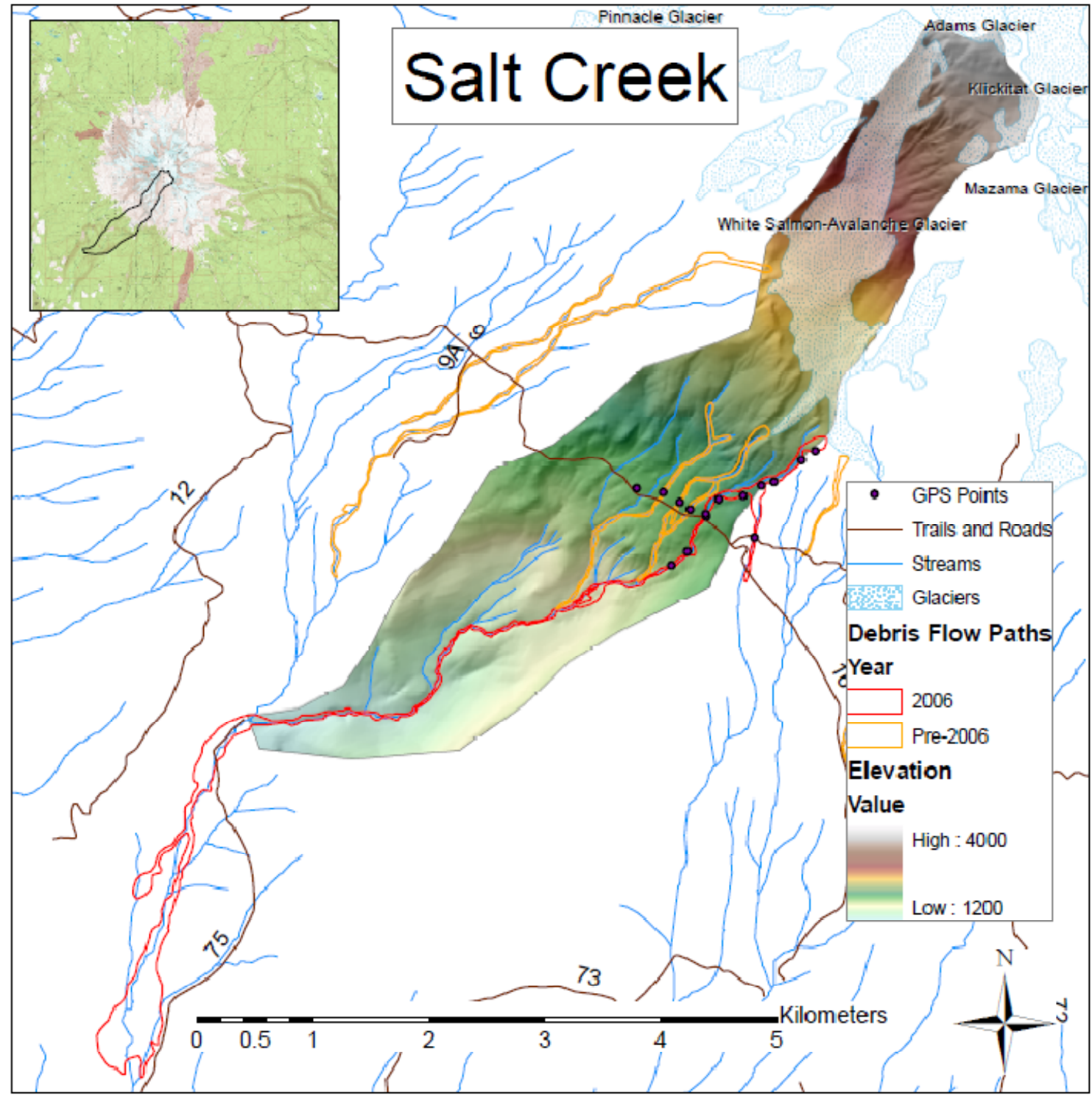

Figure 67: Map of Salt Creek Drainage. Black numbers are trail and road indicators, black dots are GPS points. 


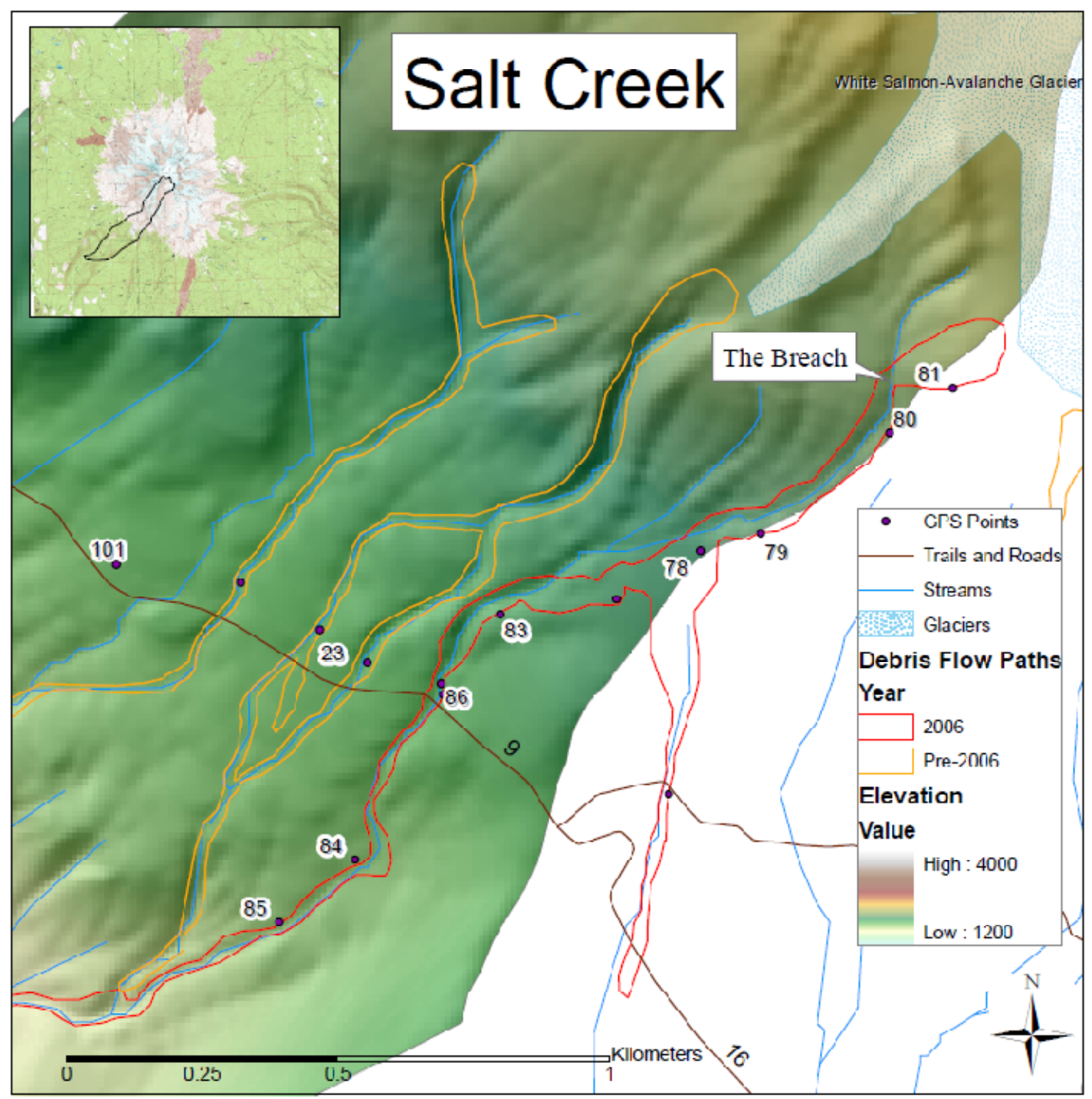

Figure 68: Close up map of Upper Salt Creek Drainage. Black numbers are trail and road indicators, black numbers with white halos refer to GPS points.

\subsubsection{Salt Creek}

Salt Creek is located on the southwestern side of Mt. Adams. In 2006 this drainage experienced a debris flow that traveled approximately 2,100 $\mathrm{m}$. This debris flow was caused by collapse of over-steepened and saturated moraine material (Darryl Lloyd, Personal Communication 2007). 
This debris flow travelled through a gap in a moraine, named "The Breach" deepening and widening it considerably. The Salt Creek Debris Flow spilled over into the Crofton Creek Drainage in several places. See section 4.2.5. for more information. The Salt Creek Debris Flow entered Cascade Creek Drainage at an elevation of 1,140 m. The flow cut deeply down Salt Creek (Figure 72) deposited in the lower Salt Creek Drainage (Figure 71) and entered The Cascade Creek Marsh at around 1,000 m in elevation (Figures $69 \& 70$ ). The marsh rose by $1 \mathrm{~m}$ as a result of this flow, and many hardwood trees were killed (Darryl Lloyd, Personal Communication 2007).

\section{Reconnaissance}

Initial reconnaissance was conducted in the summer of 2009. Hiking across Trail 9 in the Salt Creek Drainage, several streams were crossed. Nearly all these streams had evidence of debris flow activity. The most significant and most recent appearing debris flow channel was found at GPS point 21 (Figure 73). Here the channel is extremely steep, and the western bank is up to about $30 \mathrm{~m}$ high in some locations. Small vegetation was growing in a few places, but the channel center and sidewalls were clear. At other stream crossings in the Salt Creek Drainage, GPS points 22 and 23, similar channelized incision was visible but appeared older, with fewer boulders and more vegetation (Figures $74 \& 75$ ).

\section{Initiation Zone}

During the summer of 2009 the upper Salt Creek Drainage was explored by hiking a ridge between the Salt Creek and Crofton Creek drainages. The channel was 
easily followed up the mountain, and at GPS point 77 the channel split into two with one going down into the Crofton Creek Drainage and the other into the Salt Creek Drainage. Areas in the channel appeared wet looking. These are places where permafrost in the lateral moraine, exposed by the debris flow, were melting (Figure 76). The breach was clearly visible as a large ' $\mathrm{V}$ ' shaped incision into an orange brown moraine. From this location, looking down, the extent of the debris flow could be seen in both the Crofton Creek and Salt Creek drainages (Figure 77). The initiation zone was found when looking up through The Breach. Visible was a scarp with wet looking sediment (Figure 78). A view from the top of the initiation zone was provided by Darryl Lloyd (Figure 79) where a fresh cut in the edge of the rock glacier is visible. Telephoto figures were also created by Darryl Lloyd that show the initiation material of the debris flow (Figure 80) and highlight the path it took (Figure 81).

\section{Sample Collection}

One soil sample for Salt Creek was taken from GPS point 81. This location was immediately to the side of 'The Breach' on an area geologically mapped the same as the initiation zone and was visibly the same. 


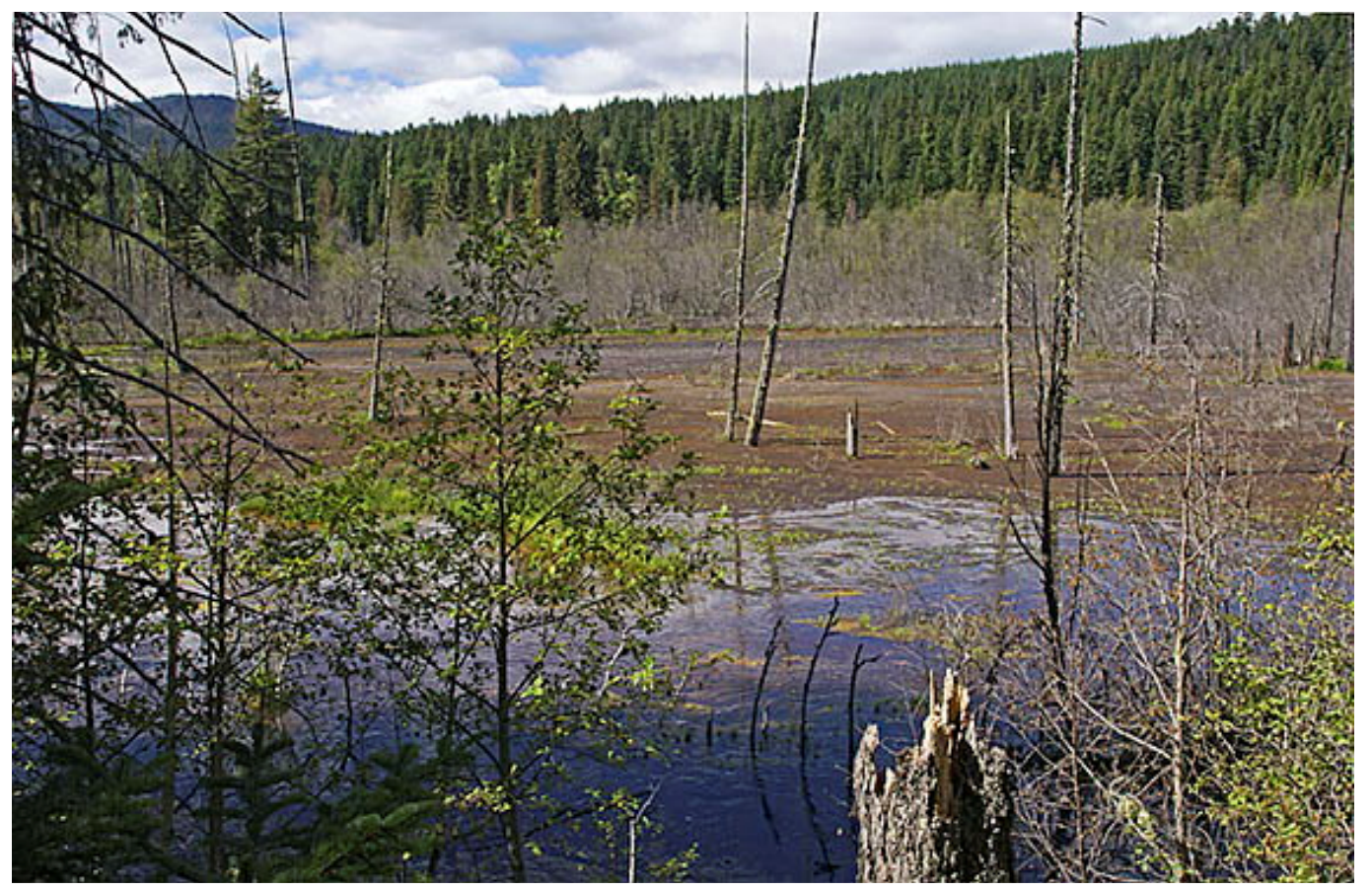

Figure 69: Cascade Creek Swamp, where the Salt Creek debris flow ended raising the water level by around a meter. Photo by Darryl Lloyd in 2007.

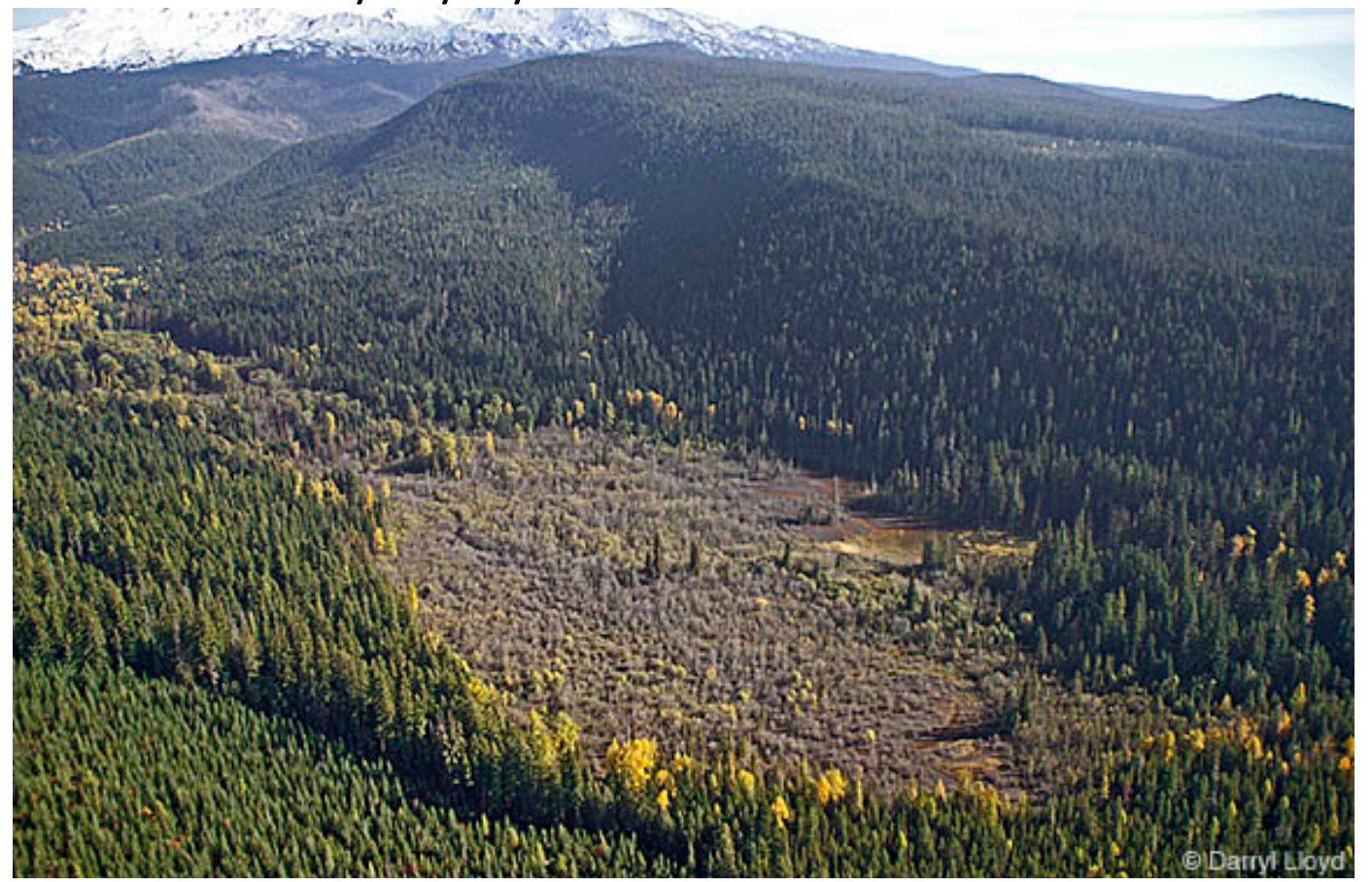

Figure 70: View of Cascade Creek Marsh, the end of the Salt Creek Debris Flow. Photo taken by Darryl Lloyd in 2007. 


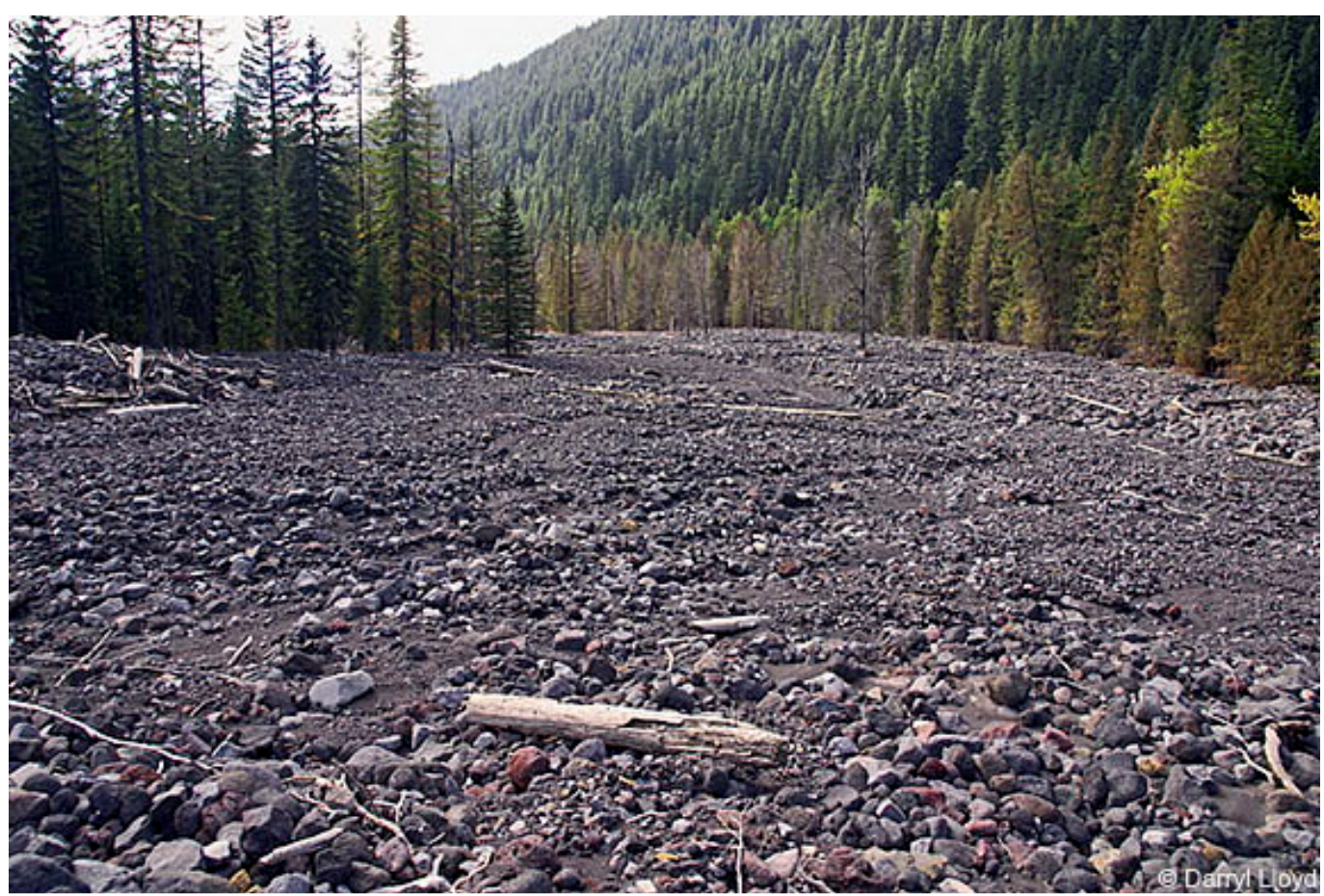

Figure 71: Salt Creek Debris Flow deposits in the lower Salt Creek Drainage. Photo taken by Darryl Lloyd in 2007.

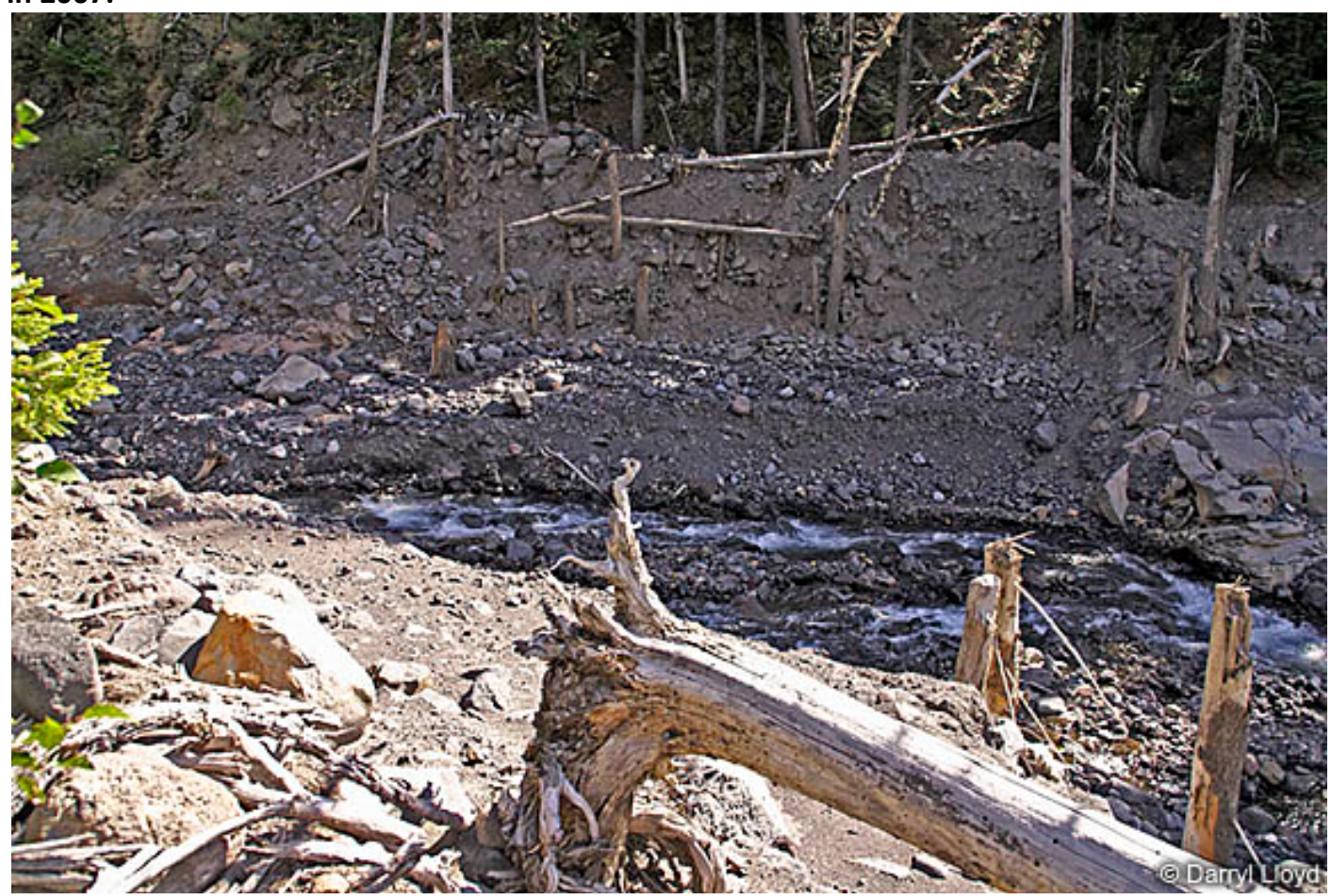

Figure 72: Lower Salt Creek Drainage showing run up height on the side of the channel in the background. Photo taken by Darryl Lloyd on September 23, 2007. 


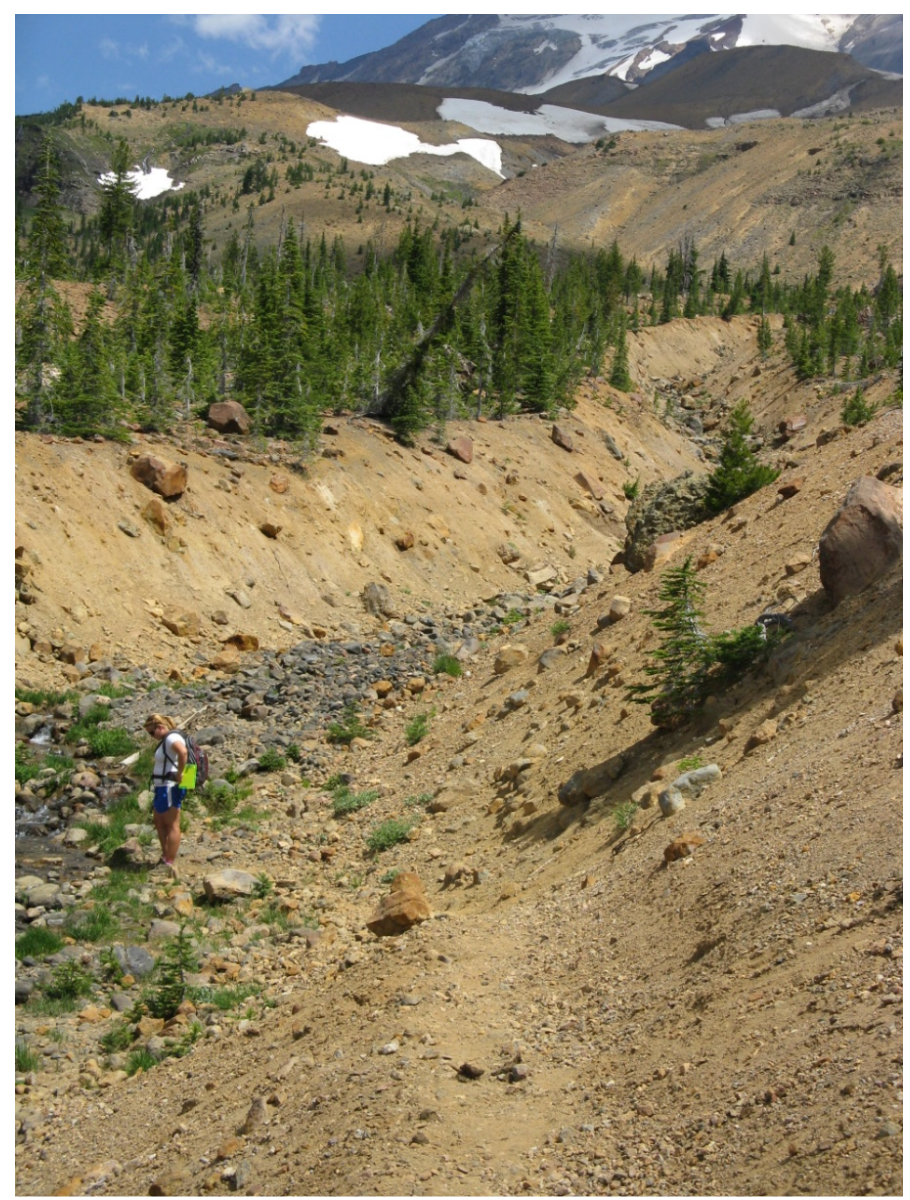

Figure 74: Salt Creek Drainage at GPS point 23. Photo taken during the summer of 2009

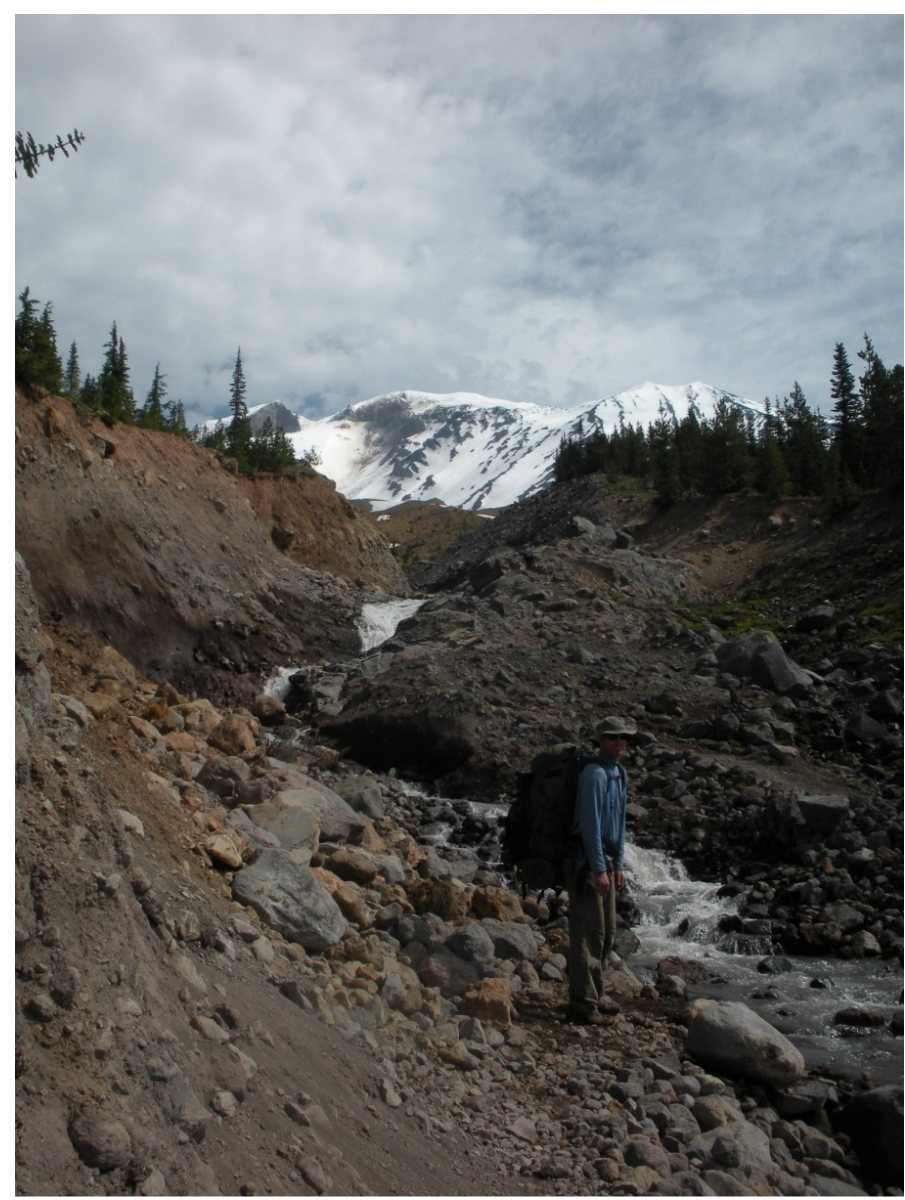

Figure 73: Salt Creek Drainage at GPS point 21. Photo taken during the summer of 2010 


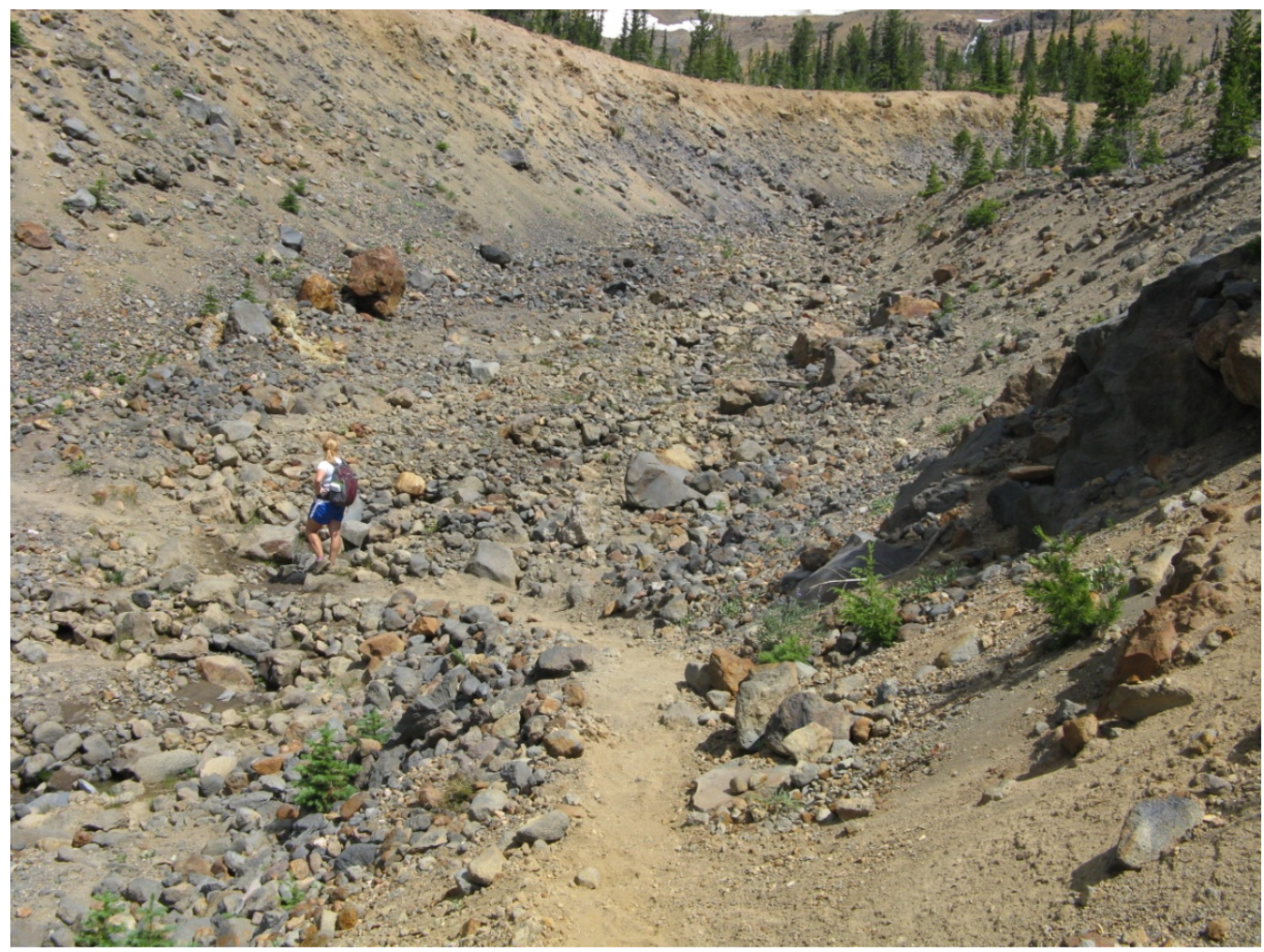

Figure 75: Salt Creek Drainage at GPS point 22. Photo taken during the summer of 2009.

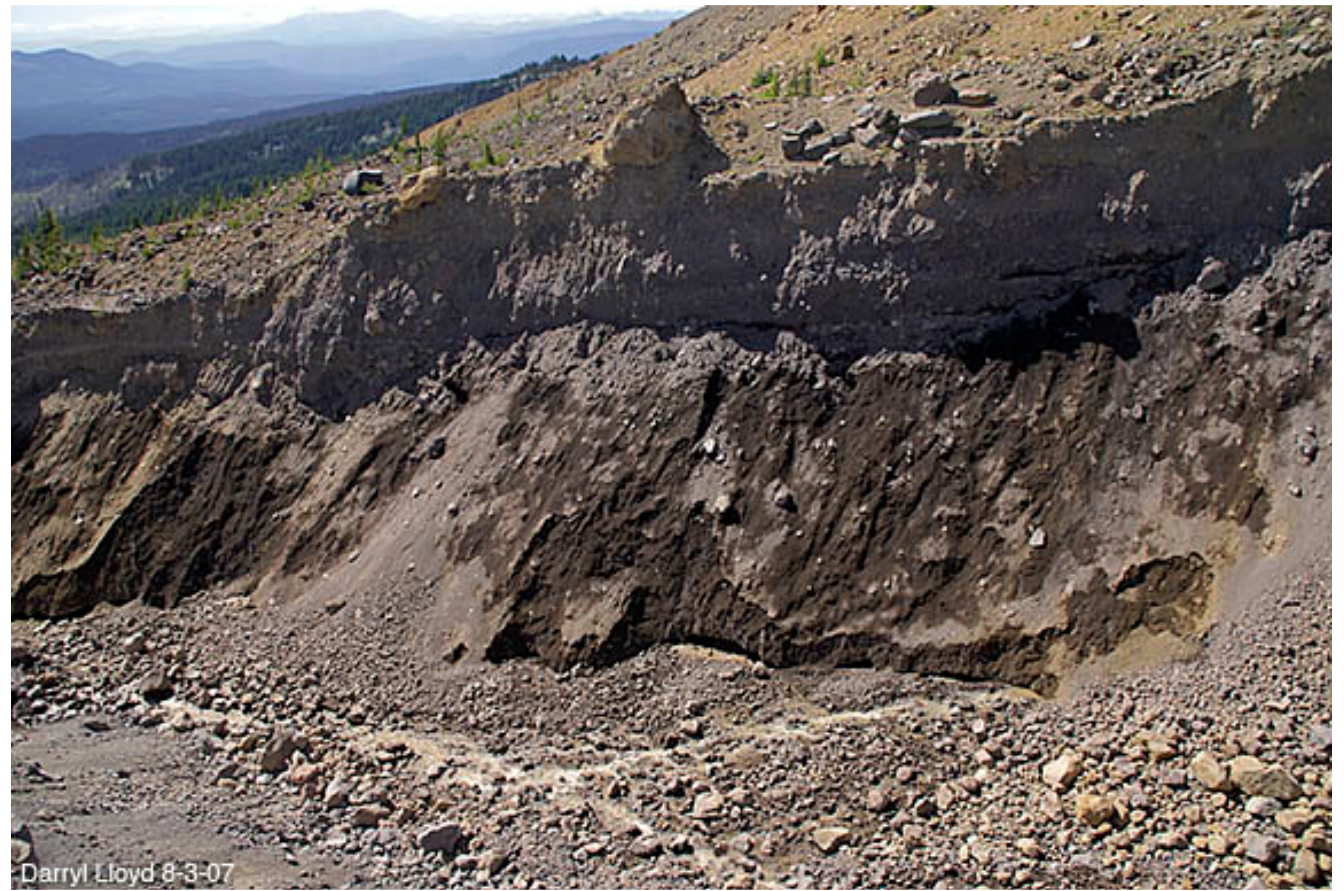

Figure 76: Melting permafrost exposed by the Salt Creek Debris Flow of November, 2006. Layer shows lahar deposit overlying glacial till overlying old glacial ice. Photo taken by Darryl Lloyd on August 30, 2007. 


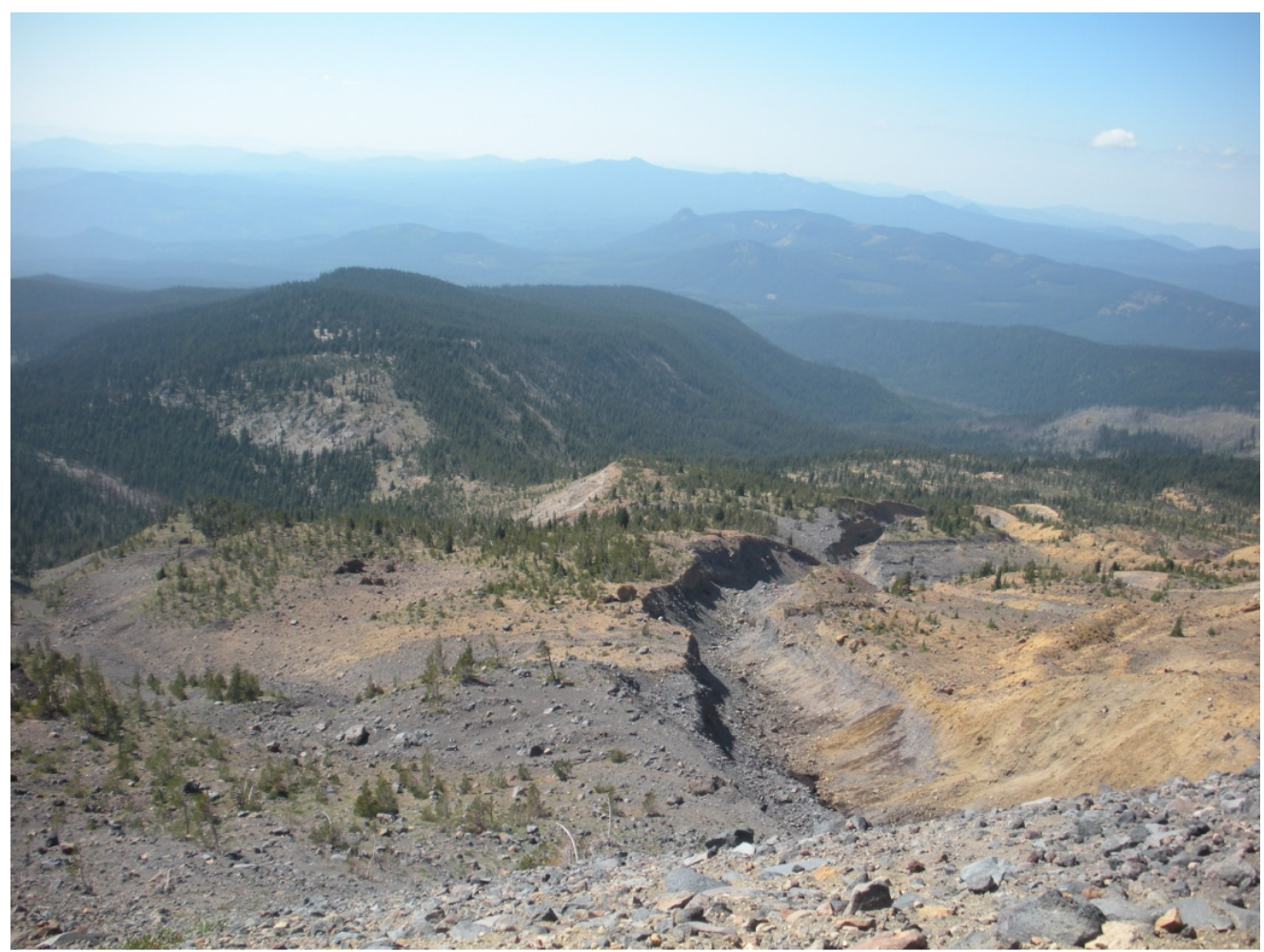

Figure 77: Salt Creek Debris Flow looking South. Photo taken from GPS point 81 in September 2009.

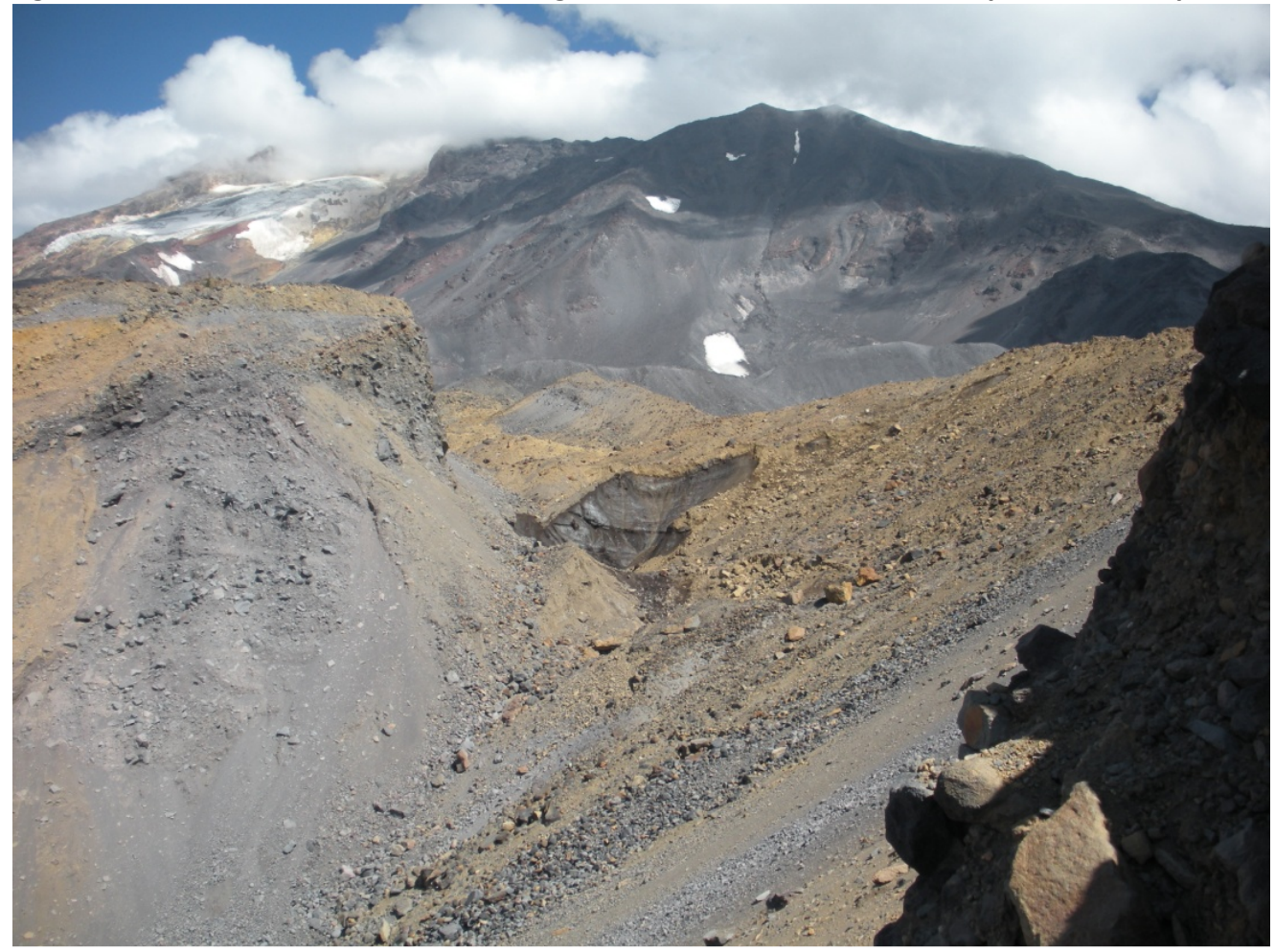

Figure 78: The Salt Creek Debris Flow looking up through "The Breach" at the initiation zone. Photo taken from GPS point 81 in September, 2009. 


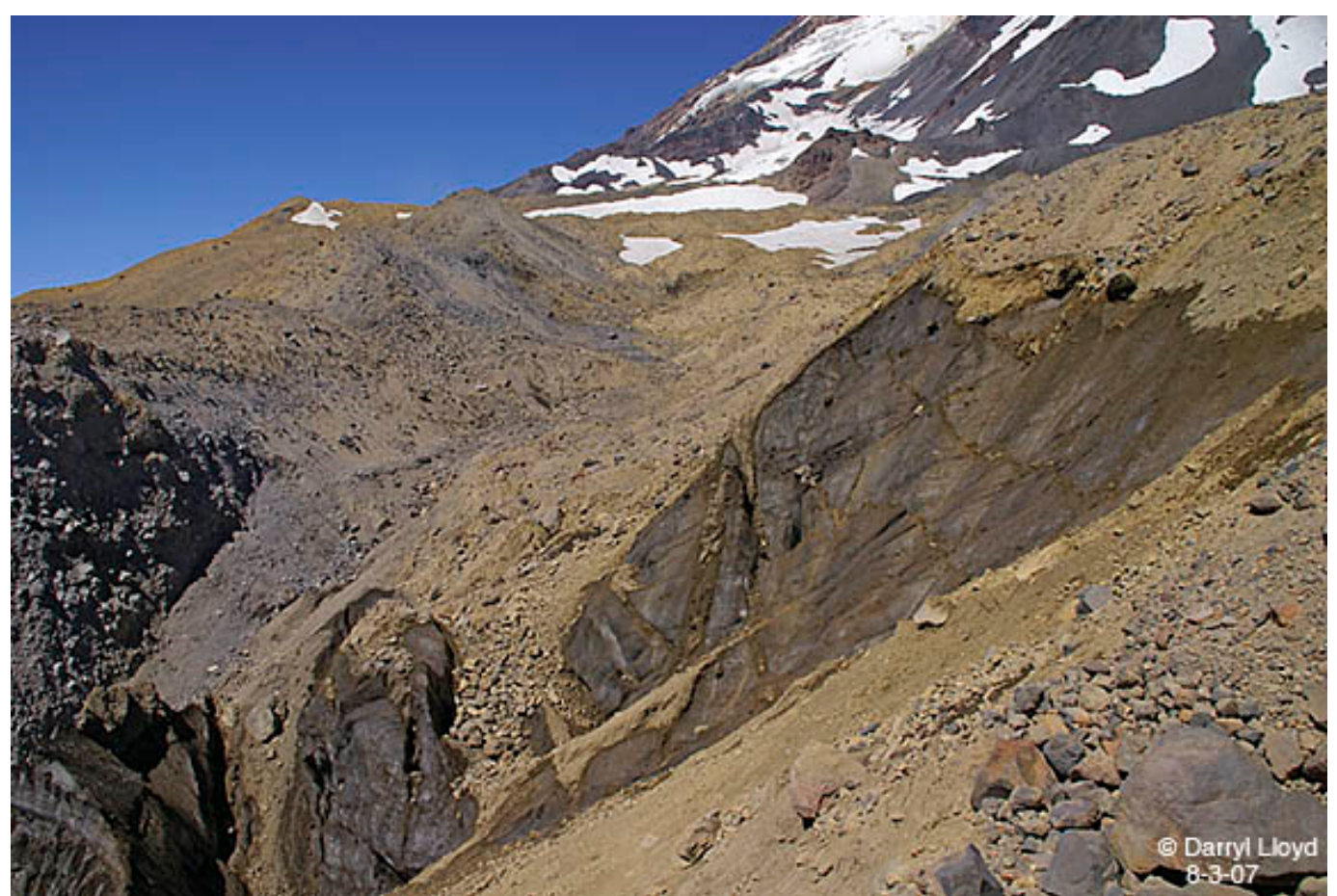

Figure 79: View of Salt Creek Debris Flow Initiation Zone. Edge of rubble covered glacier is exposed where material failed. Photo taken by Darryl Lloyd on August 3, 2007.

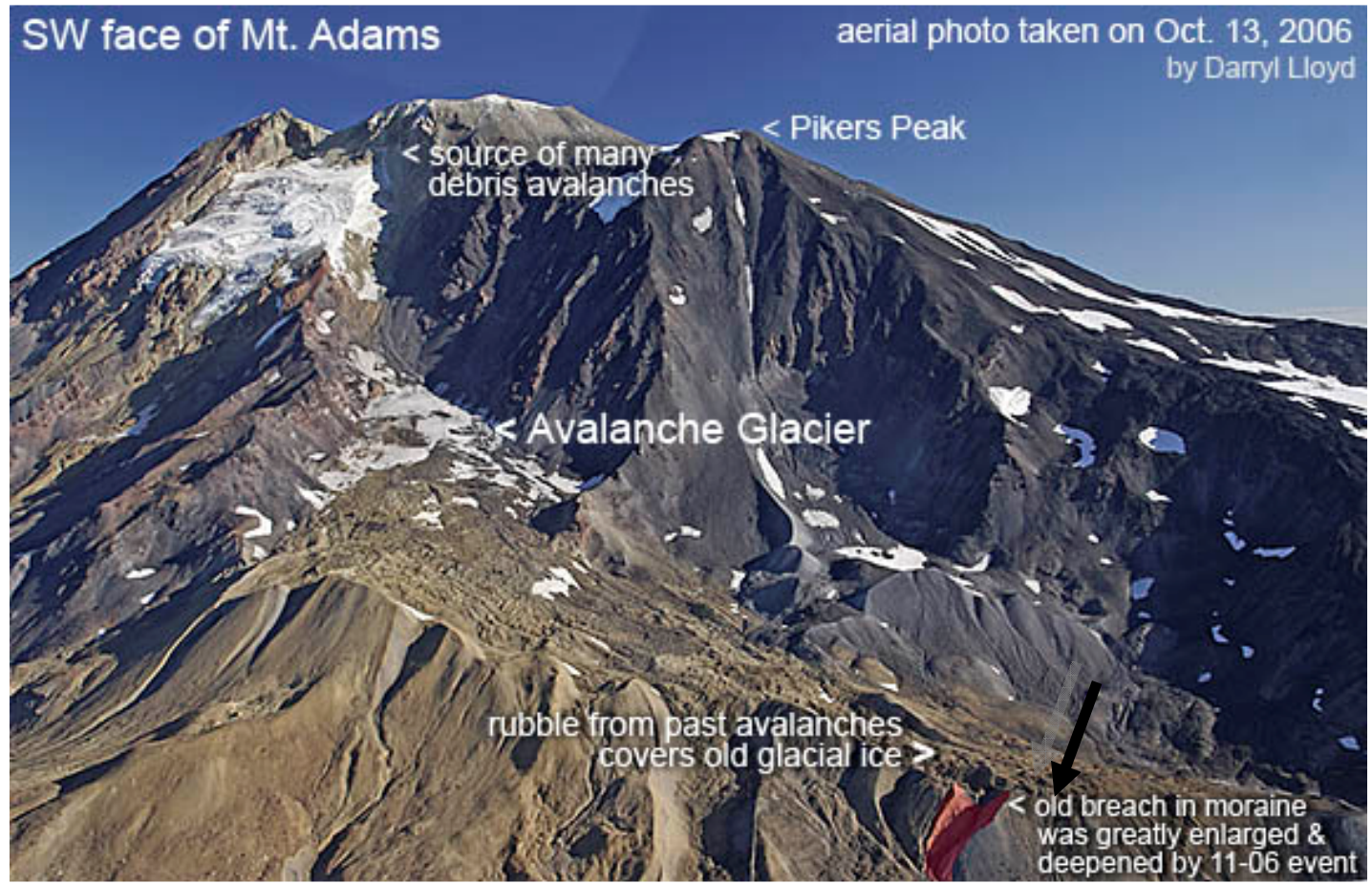

Figure 80: Southwest face of Mt. Adams before the November, 2006 storm. The old moraine breach was widened and deepened as the Salt Creek Debris Flow occurred. The initiation site is highlighted in red and pointed out by the black arrow. Figure by Darryl Lloyd, photo taken October 13, 2006. 


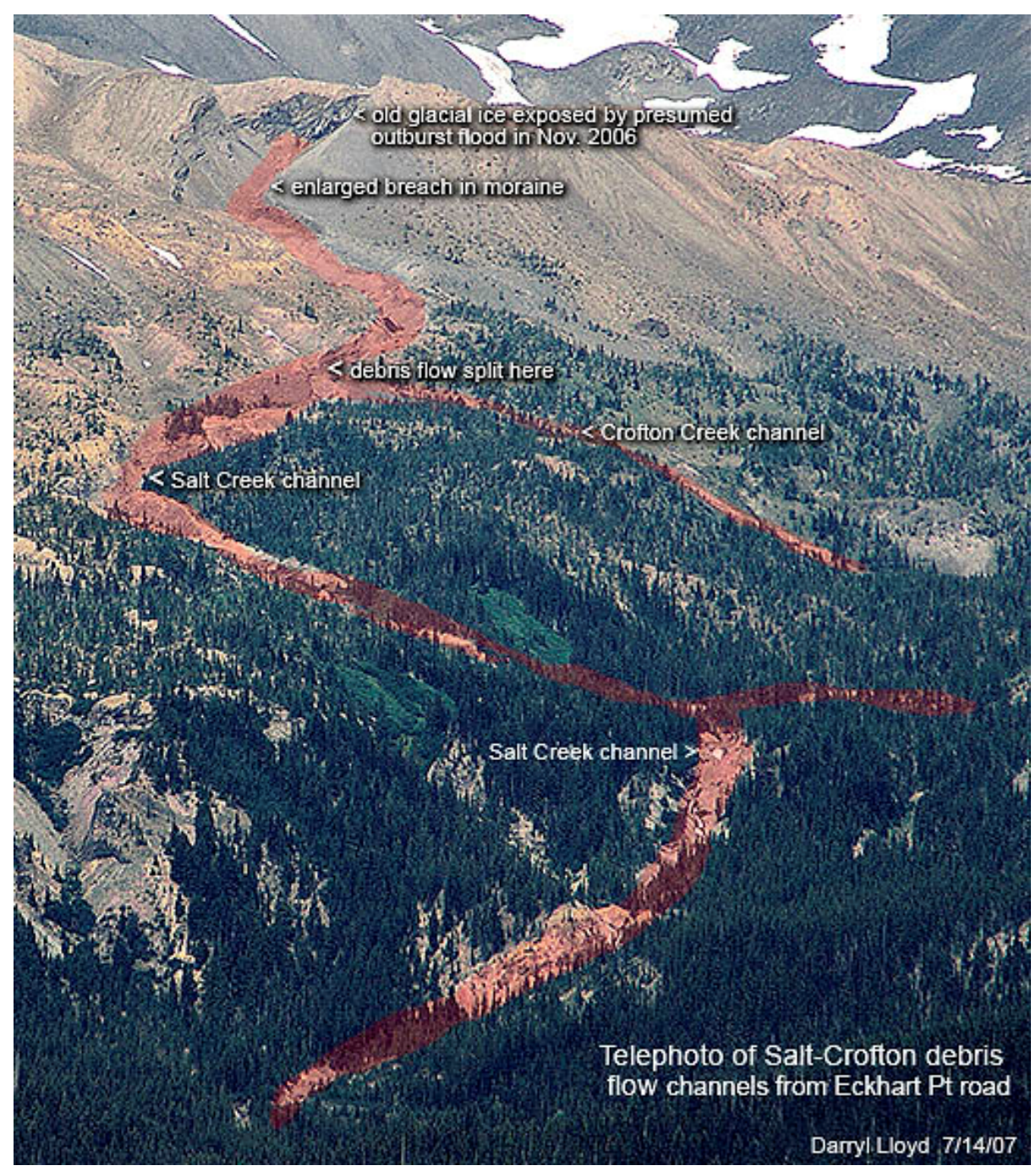

Figure 81: Telephoto of the Salt Creek Debris Flow. The path of the channel is highlighted in red and the area when the flow crossed into the Crofton Creek channel is labeled. Figure by Darryl Llyod, photo taken July 14, 2007.

Sieve Results

The sample from Salt Creek Drainage is presented in Table 27 below. The sample contained $27 \%$ gravel, $71 \%$ sand and $3 \%$ fines.

Table 27: Salt Creek sieve results, sample 140. See Table 1 for exact size definitions.

\begin{tabular}{|l|r|r|r|r|r|r|r|}
\hline \multirow{2}{*}{$\#$} & Bulk Density (g/cm3) & \multirow{2}{*}{ Gravel } & \multirow{2}{*}{ Sand } & \multicolumn{3}{|c|}{ Sand Distribution } & \multirow{2}{*}{$\begin{array}{c}\text { Silt \& } \\
\text { Clay }\end{array}$} \\
\cline { 5 - 8 } & & & & Coarse Sand & Medium Sand & Fine Sand & \\
\hline 1 & None & 48 & 50 & 37 & 9 & 4 & 2.5 \\
\hline
\end{tabular}


Table 28: Salt Creek Drainage Basin attributes

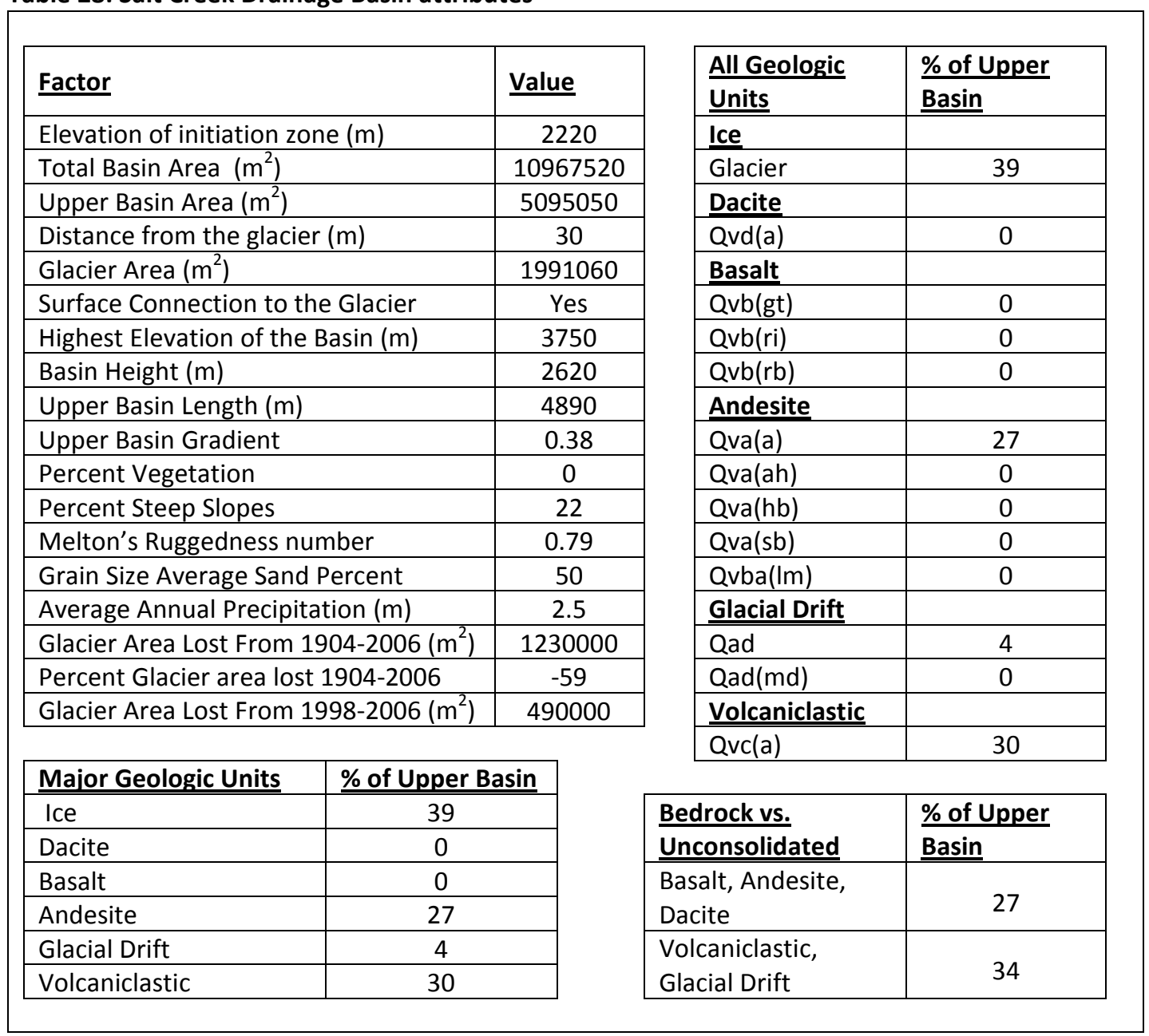

\section{Basin Attributes}

The elevation of the Salt Creek Initiation Zone is about 2,220 m, on a deposit geologically mapped as Quaternary Glacial Drift (Department of Natural Resources, 2005). The total basin area is $11.0 \mathrm{~km}^{2}$, and the upper basin is $5.1 \mathrm{~km}^{2}$. The distance from the stream beginning to the glacier is 30 meters, and $2.0 \mathrm{~km}^{2}$, or $39 \%$, of the upper basin is covered in glaciers. The stream is directly connected to the glacier. The highest elevation of the basin is $3,747 \mathrm{~m}$, the basin height is $2,620 \mathrm{~m}$, and the basin length is 
$4,890 \mathrm{~m}$. The gradient of the upper basin is $0.38,0 \%$ of the upper basin is vegetated and $22 \%$ are steep slopes. MRN is calculated as 0.79 , and the average annual precipitation is $2.5 \mathrm{~m}$.

\subsubsection{Trappers Creek}

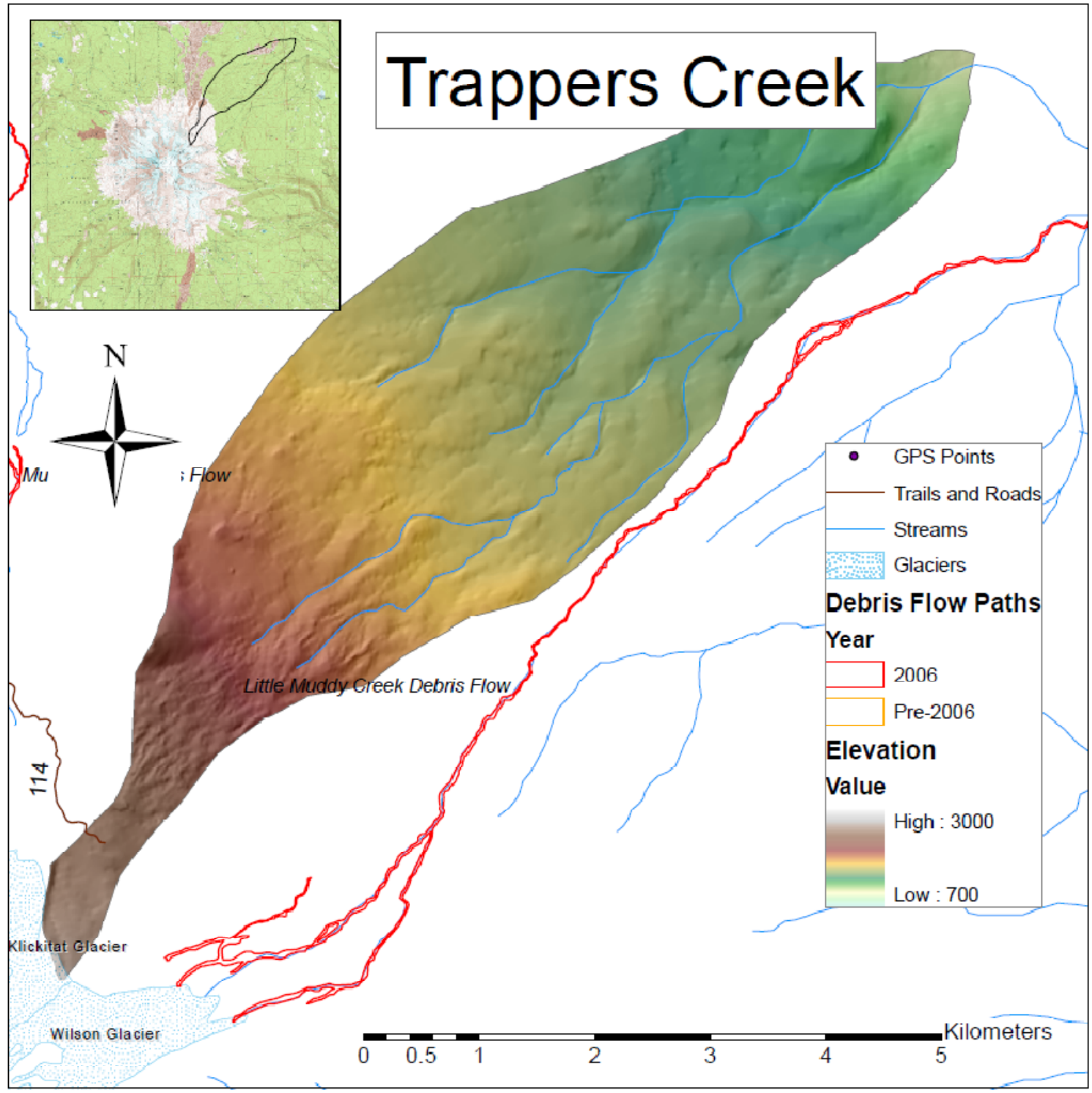

Figure 82: Map of Trappers Creek Drainage. Black numbers are trail and road indicators, black numbers with white halos refer to GPS points. 
Trappers Creek is located on the northeast side of Mt. Adams. This drainage is very remote and only the very uppermost portion is accessible from Trails 13 and 114 . This drainage is very secluded and not popular for outdoor recreation. Debris flow activity was not observed for this drainage.

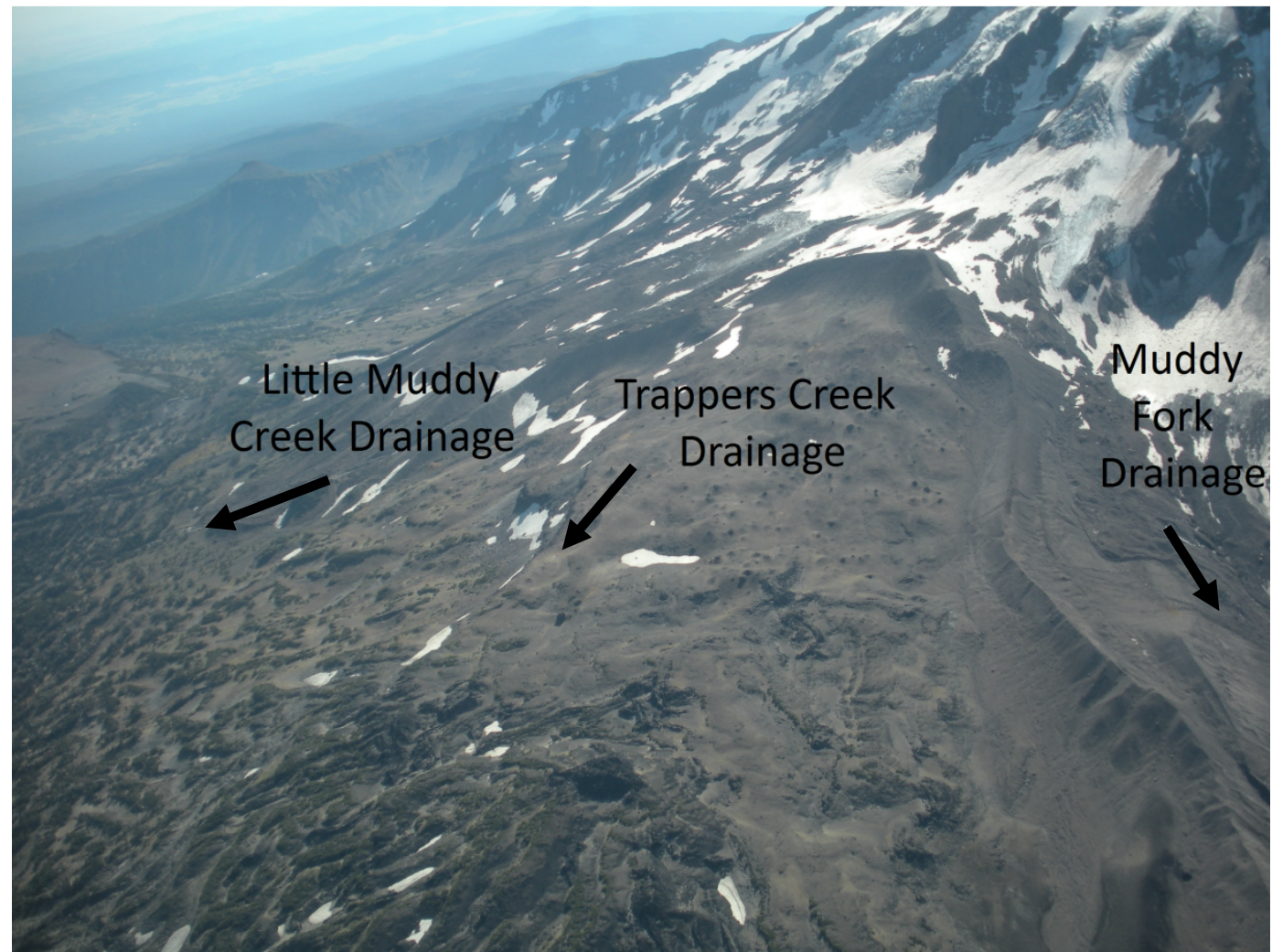

Figure 83: Oblique air photo of the upper Trapper's Creek drainage. Black arrows point down slope. Photo taken September $30^{\text {th }}, 2010$.

\section{Reconnaissance}

Due to limited field season, a large study area and difficulty of access, orthophotos and oblique air photos were used to determine debris flow activity for Trappers Creek. The oblique air photos showed normal stream activity, and no areas of incision or deposition were found. Orthophoto analysis of the drainage showed no difference in the channel between the pre storm 2006 photo and the 2009 photo. 


\section{Sample Collection \& Sieve Results}

Due to limited field season, a large study area and difficulty of access samples were not collected for Trappers Creek.

Table 29: Trappers Creek Drainage Basin attributes

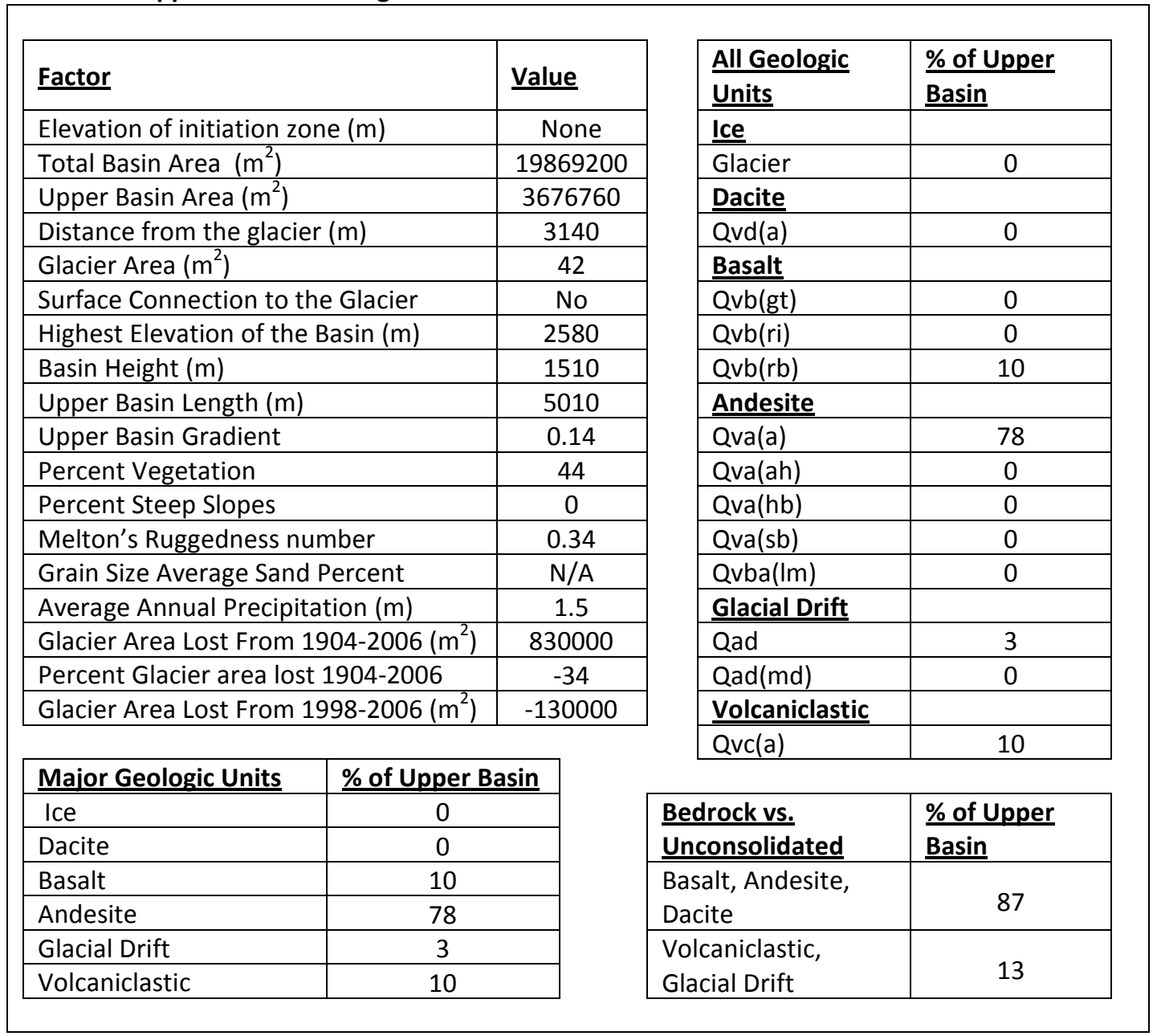

\section{Basin Attributes}

The total Trapper's Creek Basin area is $19.9 \mathrm{~km}^{2}$, and the upper basin is $3.7 \mathrm{~km}^{2}$.

The distance from the stream beginning to the glacier is 3,140 meters, and $40 \mathrm{~m}^{2}$, or $0 \%$, of the upper basin is covered in glaciers. The stream is not directly connected to the glacier. The highest elevation of the basin is $2,580 \mathrm{~m}$, the basin height is $1,510 \mathrm{~m}$, and 
the basin length is $5,010 \mathrm{~m}$. The gradient of the upper basin is $0.14,44 \%$ of the upper basin is vegetated and $0 \%$ are steep slopes. MRN is calculated as 0.34 , and the average annual precipitation is $1.5 \mathrm{~m}$.

\subsection{Summary of Results}

Basins experiencing debris flows as a result of the 2006 storm were Adams Creek, Big Muddy Creek, Lewis Creek, Little Muddy Creek, Muddy Fork, Rusk Creek and Salt Creek. Basins that had evidence of old debris flows were Cascade Creek, Crofton Creek, Hellroaring Creek, and Morrison Creek. Basins without evidence of debris flows were Bird Creek, East Fork, Gotchen Creek, Horseshoe Creek, Killen Creek, Riley Creek and Trappers Creek. Every drainage had a MRN of greater than .3, suggesting that each is capable of producing a debris flow (Jackson et al., 1987).

- A landslide initiated one debris flow, three were initiated by heavy water flow and in channel landslides, and three were initiated by a coalescence of eroded channels (headless debris flows).

- $\quad$ MRN ranged from 0.86 to 0.31 with an average value of $0.60 \pm .003$

- 11 drainages were directly connected to the glacier, 7 were not.

- $\quad$ Rainfall varied from 3.3 to 1.5 meters per year with an average value of $2.3 \pm .008$ meters per year.

- Percent vegetation values were between 44 and $0 \%$, averaging $15 \pm .2 \%$.

- Percent steep slopes ranged from 31 to $0 \%$ with an average value of $14 \pm .1 \%$. 
- The most common geologic material was andesite, averaging $47 \pm .4 \%$ of the upper basin, second was glacial drift averaging $24 \pm .2 \%$ of the upper basin, third was ice with $22 \pm .2 \%$ of the upper basin followed by volcaniclastics, basalt and dacite with $5 \pm .1,2 \pm .07$ and $0.6 \pm .03 \%$ of the upper basin respectively.

- Grouping the geology into three groups, bedrock (basalt, andesite and dacite) average a total of $49 \pm .4 \%$ of the upper basins, unconsolidated (volcaniclastics and glacial drift) averaged a total of $29 \pm .2 \%$ of the upper basins, leaving ice to average $22 \pm .2 \%$ of the upper basin.

- Gradient of the upper basin ranged from .62 to .18 with an average value of $.34 \pm$ .002 .

- $\quad$ The upper basin length varied from $3,710 \mathrm{~m}$ to $6,500 \mathrm{~m}$ averaging $4,974 \pm 13 \mathrm{~m}$.

- The upper basin height was between $718 \mathrm{~m}$ and 4,830 m, with an average of $1,682 \pm 8 \mathrm{~m}$.

- The total basin height ranged from 1,505 $\mathrm{m}$ to $2,870 \mathrm{~m}$, averaging $2,245 \pm 6 \mathrm{~m}$.

- The total basin area varied from $6.6 \mathrm{~km}^{2}$ to $42.9 \mathrm{~km}^{2}$.

- Glacier area lost from 1904 and 2006 ranged between 30,000 and 3,250,000 m² averaging 1,566,667 $\pm 18,060 \mathrm{~m}^{2}$

- Percent glacier area lost between 1904 and 2006 ranged from -6\% to -86\% averaging $-48 \pm .4 \%$.

- Glacier area lost from 1998 and 2006 varied between -130,000 and 890,000 $\mathrm{m}^{2}$ with an average value of $468,611 \pm 4,528 \mathrm{~m}^{2}$ 
- Each 2006 debris flow initiated in an area mapped as Quaternary Glacial Drift (Qad)( Department of Natural Resources, 2005). 


\section{Chapter 5: Statistics}

The statistical analysis of these data began with grouping the drainages based on debris flow occurrence. The two groups are the 'YES' group, which includes the drainages that experienced a debris flow as a result of the 2006 storm and the 'NO' group which includes drainages that had no evidence of debris flow occurrence or had a debris flow that had occurred before the 2006 storm. These groups are listed in Table 30.

Table 30: Drainage groupings for statistical analysis based on 2006 debris flow occurrence.

\begin{tabular}{|l|l|}
\hline YES & NO \\
\hline Adams Creek & Bird Creek \\
Big Muddy Creek & Cascade Creek \\
Lewis Creek & Crofton Creek \\
Little Muddy Creek & East Fork \\
Muddy Fork & Gotchen Creek \\
Rusk Creek & Hellroaring Creek \\
Salt Creek & Horseshoe Creek \\
& Killen Creek \\
& Morrison Creek \\
& Riley Creek \\
& Trappers Creek \\
& \\
\hline
\end{tabular}

\subsection{Analysis of Variance}

One way analysis of variance (ANOVA) was conducted on 21 basin attributes to determine which attributes had statistically different means for the YES and NO groups. Differences are considered to be detected if the $p$ values are less than .05 . All of the basin attributes used for this analysis are attributes that could be measured or calculated for every basin, with the exception of the sieve analysis. These data were only 
collected for some of the basins but were still tested for those basins. The attributes used and the result of the ANOVA are shown in Table 31.

Table 31: Results of ANOVA tests of basin attributes grouped by debris flow occurrence.

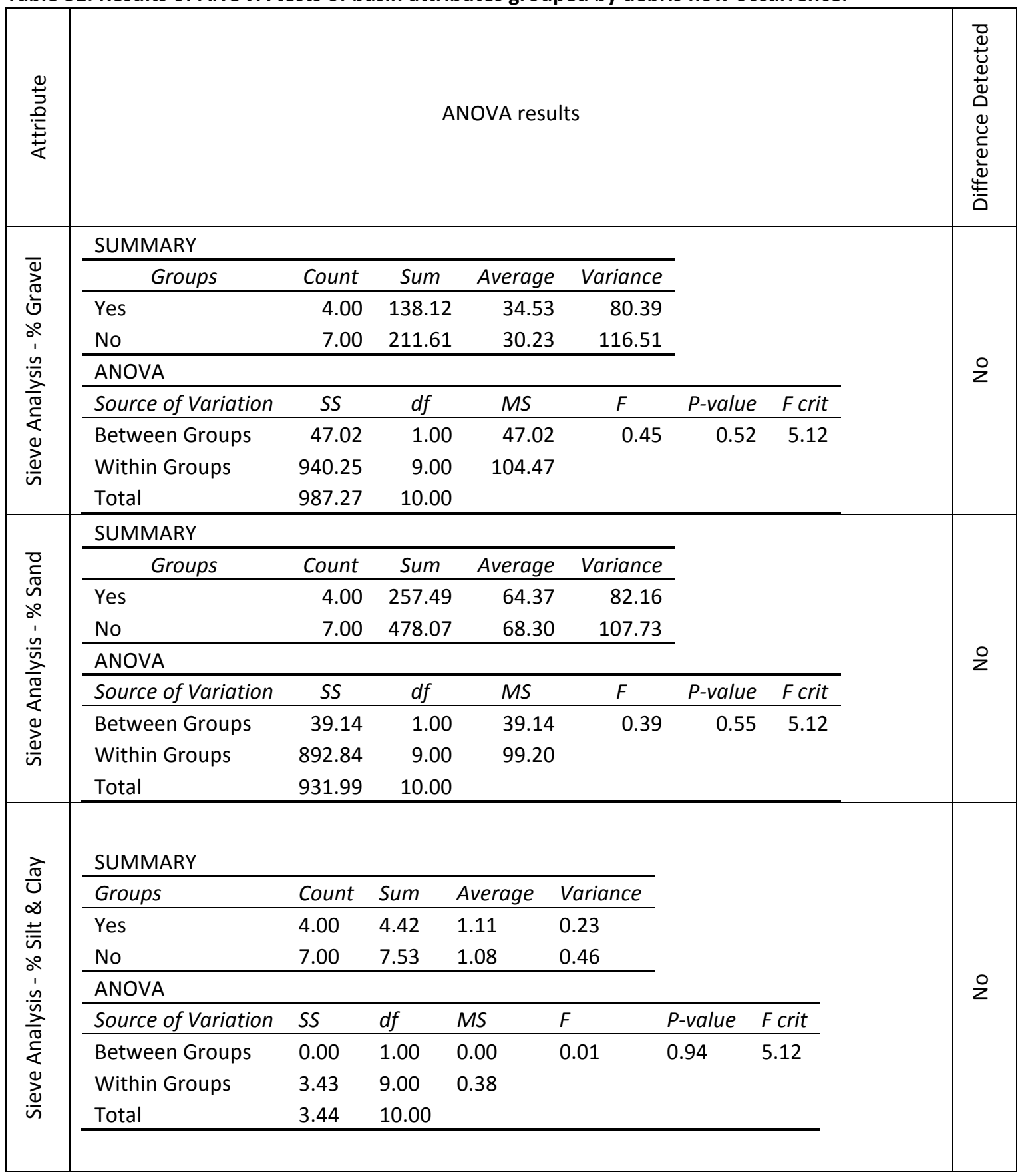


Table 31 Continued

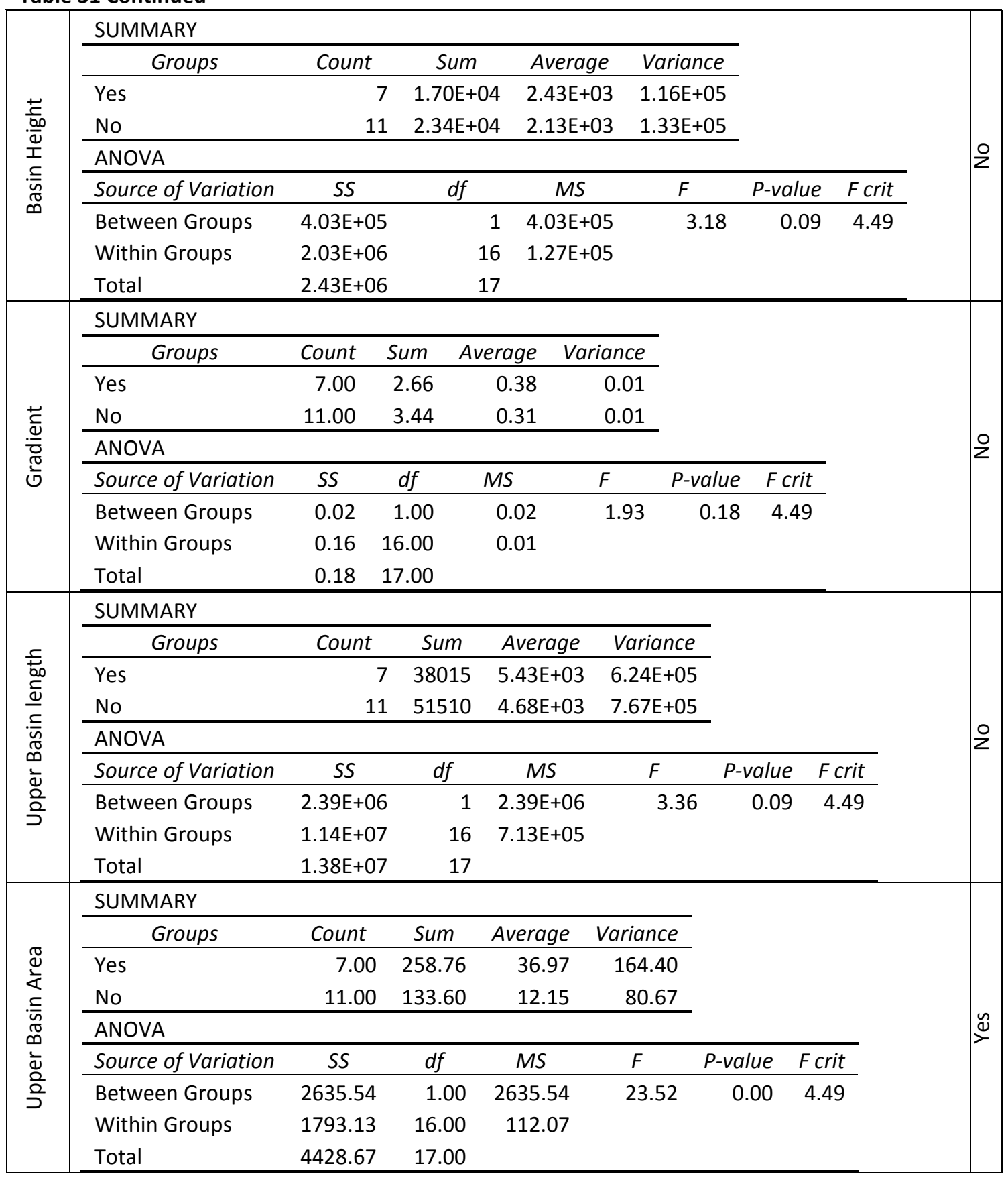


Table 31 Continued

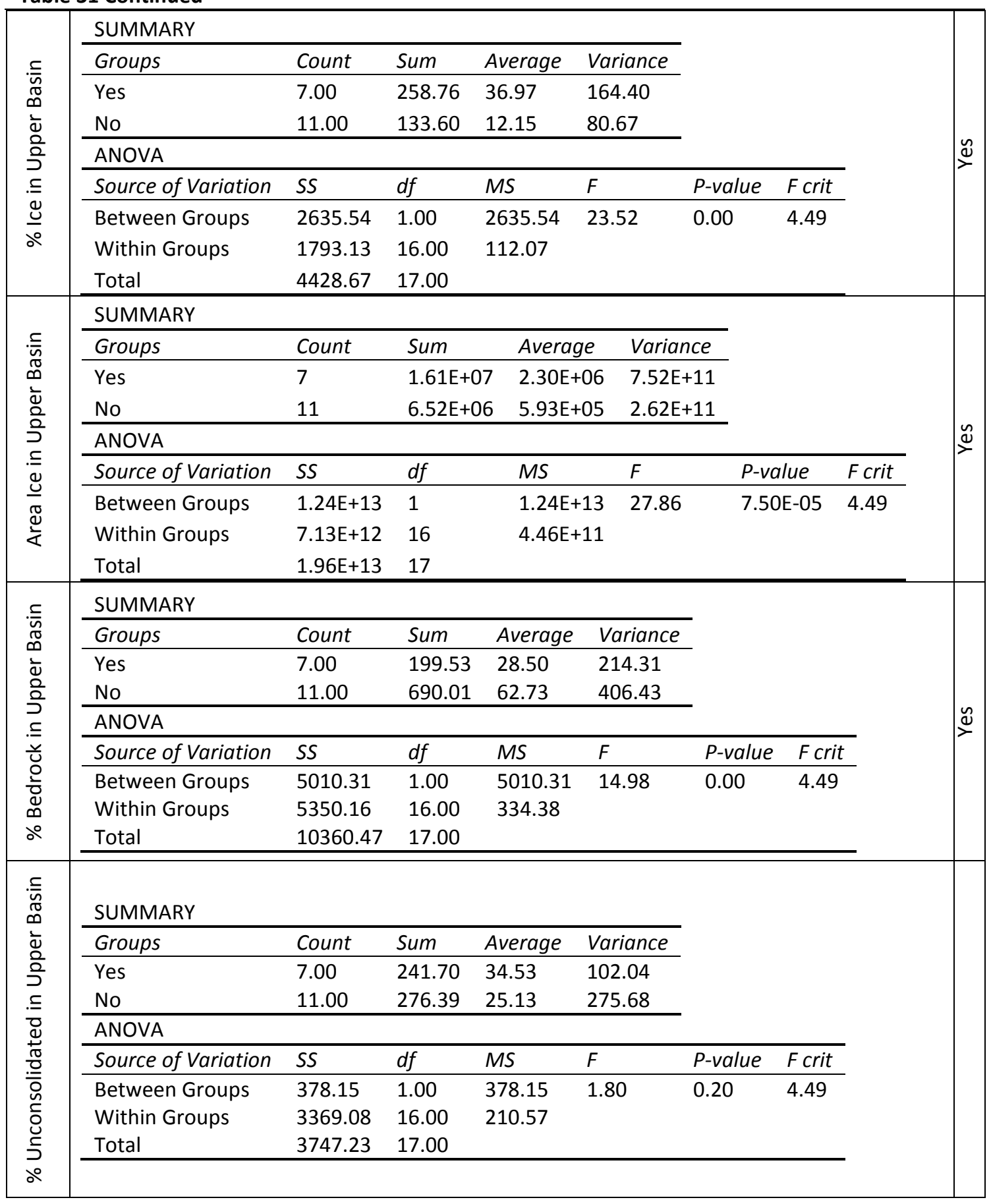


Table 31 Continued

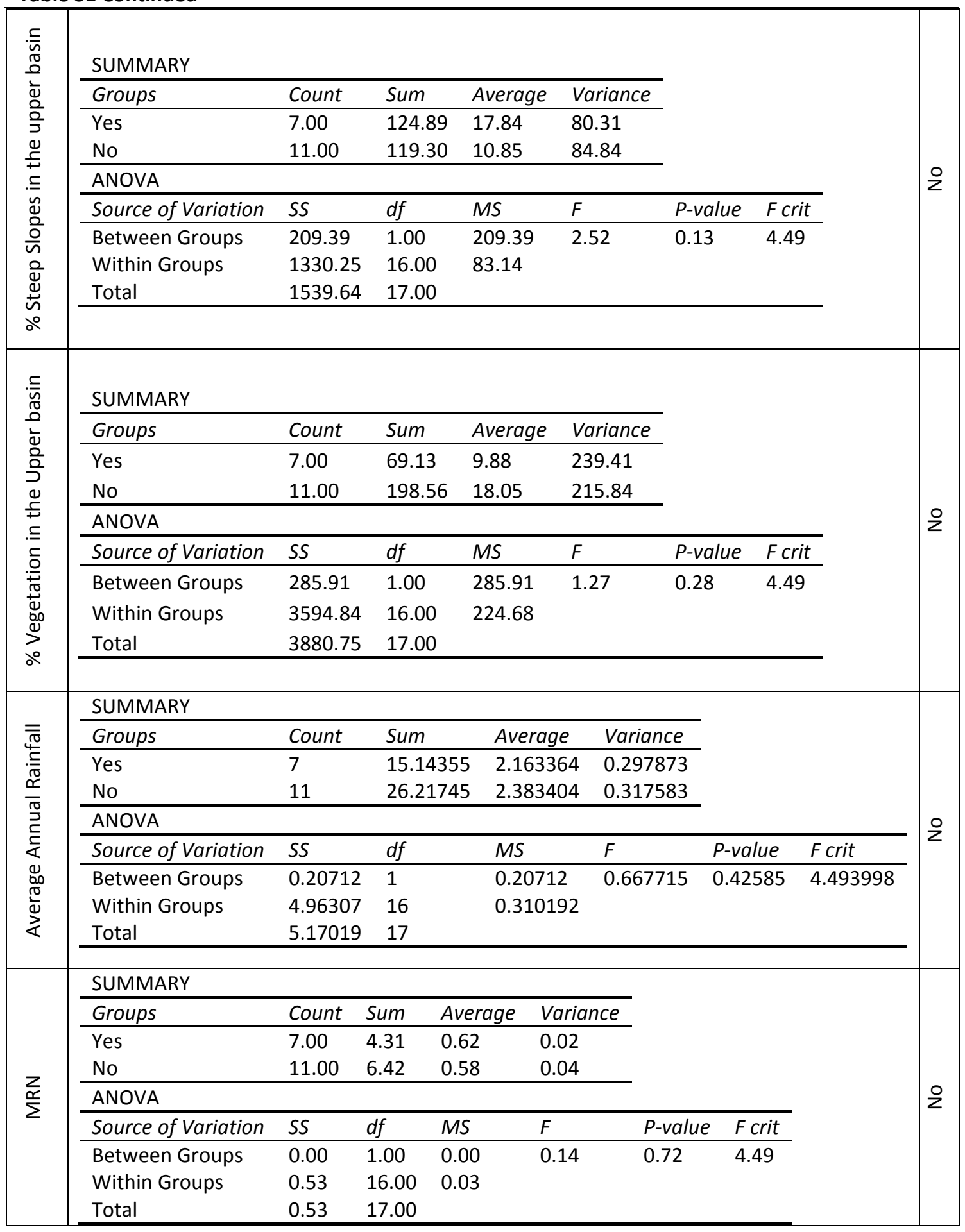


Table 31 Continued

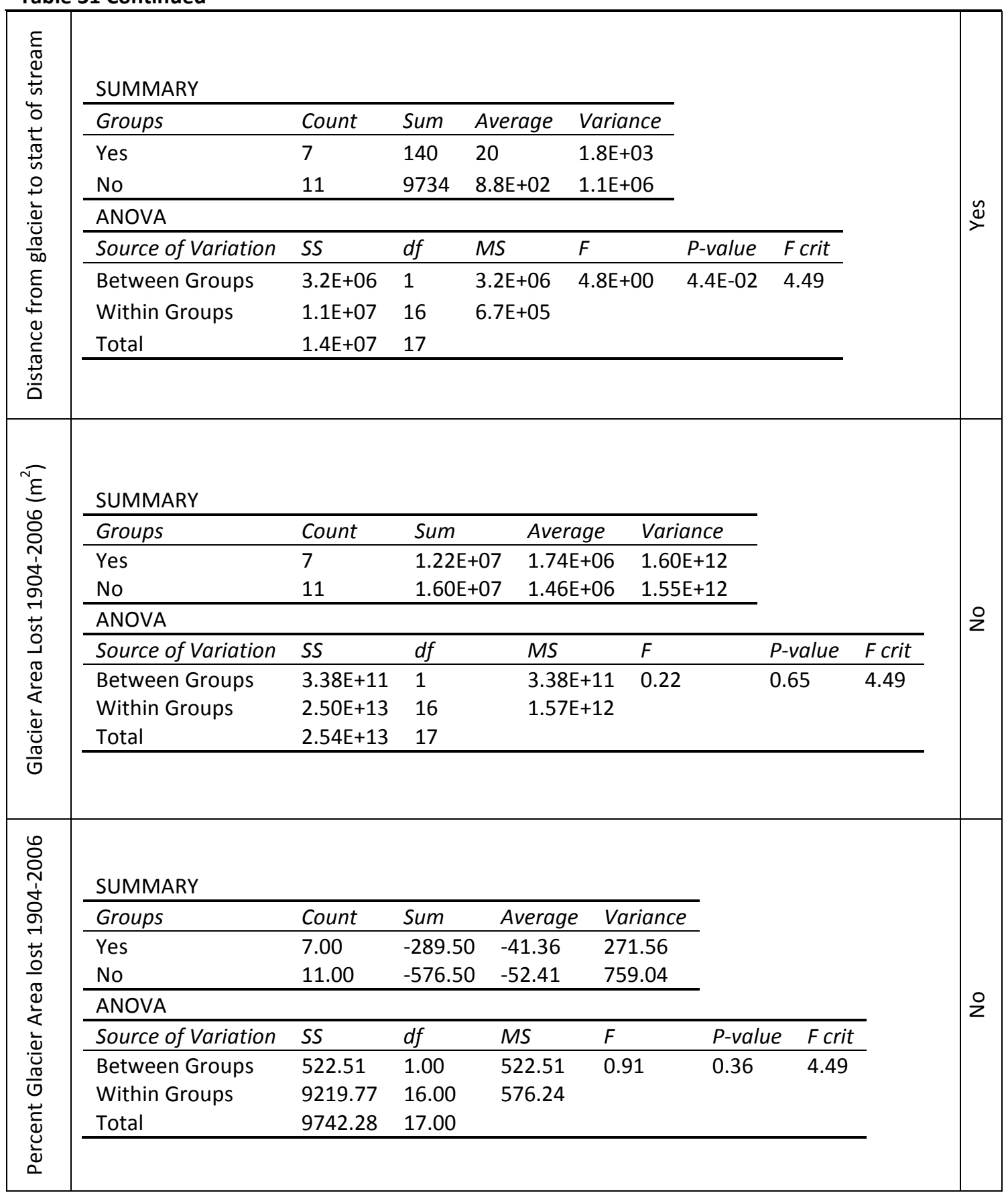


Table 31 Continued

\begin{tabular}{|c|c|c|c|c|c|c|c|c|}
\hline \multirow{9}{*}{ 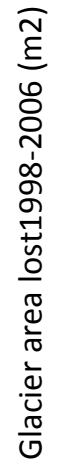 } & \multicolumn{5}{|l|}{ SUMMARY } & & & \multirow{9}{*}{ 운 } \\
\hline & Groups & Count & Sum & Average & Variance & & & \\
\hline & Yes & 7.00 & $3.64 \mathrm{E}+06$ & $5.20 \mathrm{E}+05$ & $6.87 \mathrm{E}+10$ & & & \\
\hline & No & 11.00 & $4.80 \mathrm{E}+06$ & $4.36 \mathrm{E}+05$ & $1.15 \mathrm{E}+11$ & & & \\
\hline & \multicolumn{7}{|l|}{ ANOVA } & \\
\hline & Source of Variation & SS & $d f$ & $M S$ & $F$ & P-value & F crit & \\
\hline & Between Groups & $3.02 \mathrm{E}+10$ & 1.00 & $3.02 E+10$ & 0.31 & 0.59 & 4.49 & \\
\hline & Within Groups & $1.57 \mathrm{E}+12$ & 16.00 & $9.78 \mathrm{E}+10$ & & & & \\
\hline & Total & $1.60 \mathrm{E}+12$ & 17.00 & & & & & \\
\hline
\end{tabular}

The analysis of variance determined that several attributes have significantly different means in the YES and NO groups. These factors are upper basin area, percent glacial coverage in the upper basin, area glacial coverage in the upper basin, percent andesite, basalt and dacite in the upper basin, and distance from glacier to start of stream. Factors determined to not have significantly different means are MRN, average annual rainfall, percent vegetation in the upper basin, percent steep slopes in the upper basin, percent volcaniclastics and glacial drift in the upper basin, upper basin length, upper basin height and gradient, sieve analysis percentages, glacier area lost from 1904 to 2006, percent glacier area lost 1904 to 2006, and glacier area lost from 1998 to 2006 . 


\subsection{Multiple Regression}

\subsubsection{Method}

The multiple regression method used for this project attempts to follow, as closely as possible, the method of Pirot (2010) in order for results to be accurately compared.

Logistic regression is used to predict the probability of an outcome by fitting predictor variables to a line. It is a simplified type of linear regression used to make the process as simple as possible. The analysis begins with a model using many predictor variables each with a coefficient (Davis, 2002; Pirot, 2010). The model takes the form of equation 3:

$$
Y=\frac{e^{\left(\alpha+\beta_{1} X_{1}+\beta_{2} X_{2}+\ldots+\beta_{n} X_{n}\right)}}{1+e^{\left(\alpha+\beta_{1} X_{1}+\beta_{2} X_{2}+\ldots+\beta_{n} X_{n}\right)}} \quad \text { Equation } 3
$$

where $\mathrm{Y}$ is the outcome predicted by predictor variables $\mathrm{X}$ with coefficients $\beta$. Multiple regression is then used to determine the weight of each predictor variable. The regression yields the coefficients of each predictor variable (Davis, 2002;Pirot, 2010). Each coefficient is then tested using the Wald test or the Likelihood Ratio Test to determine the statistical significance. The Wald Value (Equation 4) is the square of the coefficient $(\beta)$ divided by the standard error $\left(\mathrm{SE}_{\beta}\right)$ for that coefficient.

$$
W=\left(\frac{\beta}{S E_{\beta}}\right)^{2}
$$

\section{Equation 4}

After Wald testing of the coefficient of each predictor variables, the variable with the least influence, lowest Wald Value, is eliminated and the process starts again. This 
process continues until the only predictor variables left all have significant impact on the outcome.

\subsubsection{Application}

For this study, the outcome we are looking for is the occurrence of a debris flow. This is the $\mathrm{Y}$ value of which we give a 1 for YES and a 0 for NO. The predictor variables are the attributes we investigated that could be correlated across all the drainages. The letter $\mathrm{X}$ is used for these predictor variables. Some attributes could not be used due to repetition in those data. For example, the attribute total percent andesite, basalt and dacite in the upper basin is used but not total percent volcaniclastics and glacial drift in the upper basin due to the fact that one is related to the other. In addition, MRN, a factor based on basin height and area, is used but then basin height and area cannot then also be used. The first round of statistical tests showed some attributes did not have a significant difference in the mean between the groups that produced a 2006 debris flow and did not produce a 2006 debris flow. These factors are still used because the logistic regression should be able to show with more detail how important or unimportant these factors are to the prediction of a debris flow. The factors decided on for this study are listed in Table 32. A total of nine factors were used, labeled $X_{1}$ through $\mathrm{X}_{9}$ during the regression to avoid bias. 
Table 32: Raw data used for the Logistic Regression.

\begin{tabular}{|c|c|c|c|c|c|c|c|c|c|c|}
\hline Raw Data & 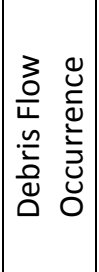 & 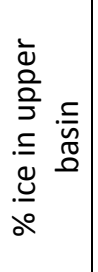 & 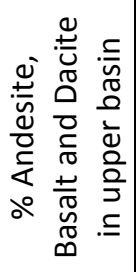 & 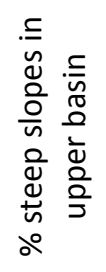 & 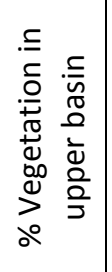 & 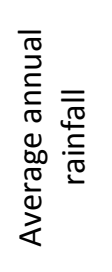 & 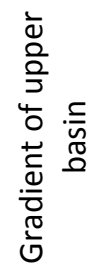 & 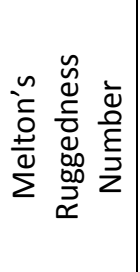 & 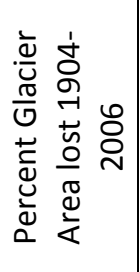 & 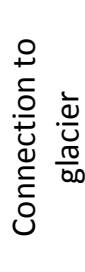 \\
\hline Drainage & Y & $X_{1}$ & $x_{2}$ & $x_{3}$ & $X_{4}$ & $X_{5}$ & $X_{6}$ & $x_{7}$ & $X_{8}$ & $X_{9}$ \\
\hline Adams Creek & 1 & 52 & 24 & 11 & 6 & 2.61 & 0.30 & 0.67 & -47 & 100 \\
\hline Big Muddy & 1 & 44 & 25 & 31 & 2 & 1.76 & 0.36 & 0.60 & -46 & 100 \\
\hline Bird Creek & 0 & 0 & 73 & 1 & 38 & 1.83 & 0.19 & 0.31 & -78 & 0 \\
\hline Cascade Creek & 0 & 19 & 16 & 11 & 6 & 2.91 & 0.37 & 0.78 & -72 & 100 \\
\hline Crofton Creek & 0 & 10 & 59 & 24 & 14 & 2.37 & 0.40 & 0.72 & -59 & 100 \\
\hline East Fork & 0 & 29 & 63 & 30 & 6 & 2.49 & 0.47 & 0.86 & -47 & 0 \\
\hline Gotchen Creek & 0 & 8 & 71 & 7 & 9 & 2.23 & 0.25 & 0.35 & -78 & 0 \\
\hline Hellroaring Creek & 0 & 22 & 39 & 16 & 29 & 1.75 & 0.29 & 0.49 & -62 & 100 \\
\hline Horeshoe & 0 & 6 & 64 & 8 & 0 & 3.27 & 0.36 & 0.80 & -86 & 0 \\
\hline Killen Creek & 0 & 11 & 84 & 3 & 18 & 2.44 & 0.23 & 0.43 & -47 & 0 \\
\hline lewis Creek & 1 & 31 & 20 & 8 & 9 & 2.93 & 0.29 & 0.61 & -47 & 100 \\
\hline Little Muddy & 1 & 18 & 60 & 8 & 44 & 1.51 & 0.30 & 0.47 & -14 & 100 \\
\hline Morrison Creek & 0 & 11 & 73 & 9 & 6 & 2.25 & 0.36 & 0.70 & -6 & 0 \\
\hline Muddy Fork & 1 & 49 & 15 & 20 & 0 & 2.23 & 0.62 & 0.42 & -54 & 100 \\
\hline Riley Creek & 0 & 17 & 62 & 10 & 28 & 3.16 & 0.34 & 0.63 & -7 & 100 \\
\hline Rusk Creek & 1 & 26 & 29 & 25 & 9 & 1.62 & 0.40 & 0.75 & -23 & 100 \\
\hline Salt Creek & 1 & 39 & 27 & 22 & 0 & 2.48 & 0.38 & 0.79 & -59 & 100 \\
\hline Trappers Creek & 0 & 0 & 87 & 0 & 44 & 1.51 & 0.18 & 0.34 & -34 & 0 \\
\hline
\end{tabular}

Table 33: Normalized data used for the Logistic Regression.

\begin{tabular}{|l|r|r|r|r|r|r|r|r|r|r|}
\hline Drainage & \multicolumn{1}{|c}{$\mathrm{Y}$} & \multicolumn{1}{c|}{$\mathrm{X}_{1}$} & \multicolumn{1}{c|}{$\mathrm{X}_{2}$} & \multicolumn{1}{c|}{$\mathrm{X}_{3}$} & \multicolumn{1}{c|}{$\mathrm{X}_{4}$} & \multicolumn{1}{c|}{$\mathrm{X}_{5}$} & \multicolumn{1}{c|}{$\mathrm{X}_{6}$} & \multicolumn{1}{c|}{$\mathrm{X}_{7}$} & \multicolumn{1}{c|}{$\mathrm{X}_{8}$} & \multicolumn{1}{c|}{$\mathrm{X}_{9}$} \\
\hline Adams Creek & 1.22 & 1.90 & -1.04 & -0.25 & -0.61 & 0.56 & -0.37 & 0.43 & 0.05 & 0.78 \\
\hline Big Muddy & 1.22 & 1.40 & -0.98 & 1.85 & -0.86 & -0.98 & 0.25 & 0.03 & 0.09 & 0.78 \\
\hline Bird Creek & -0.78 & -1.35 & 0.95 & -1.30 & 1.56 & -0.84 & -1.41 & -1.61 & -1.25 & -1.22 \\
\hline Cascade Creek & -0.78 & -0.15 & -1.34 & -0.29 & -0.61 & 1.11 & 0.26 & 1.06 & -1.02 & 0.78 \\
\hline Crofton Creek & -0.78 & -0.73 & 0.37 & 1.08 & -0.06 & 0.13 & 0.59 & 0.72 & -0.45 & 0.78 \\
\hline East Fork & -0.78 & 0.44 & 0.55 & 1.70 & -0.56 & 0.35 & 1.25 & 1.48 & 0.05 & -1.22 \\
\hline Gotchen Creek & -0.78 & -0.83 & 0.87 & -0.66 & -0.36 & -0.13 & -0.82 & -1.37 & -1.25 & -1.22 \\
\hline Hellroaring Creek & -0.78 & 0.00 & -0.43 & 0.25 & 0.96 & -0.99 & -0.51 & -0.61 & -0.58 & 0.78 \\
\hline Horeshoe & -0.78 & -0.98 & 0.57 & -0.54 & -0.98 & 1.76 & 0.17 & 1.14 & -1.58 & -1.22 \\
\hline Killen Creek & -0.78 & -0.69 & 1.39 & -1.10 & 0.21 & 0.26 & -1.01 & -0.93 & 0.05 & -1.22 \\
\hline lewis Creek & 1.22 & 0.56 & -1.19 & -0.57 & -0.39 & 1.15 & -0.46 & 0.10 & 0.05 & 0.78 \\
\hline Little Muddy & 1.22 & -0.26 & 0.43 & -0.59 & 1.92 & -1.43 & -0.35 & -0.70 & 1.42 & 0.78 \\
\hline Morrison Creek & -0.78 & -0.66 & 0.96 & -0.49 & -0.61 & -0.08 & 0.20 & 0.60 & 1.76 & -1.22 \\
\hline Muddy Fork & 1.22 & 1.67 & -1.40 & 0.68 & -0.98 & -0.13 & 2.75 & -1.02 & -0.23 & 0.78 \\
\hline Riley Creek & -0.78 & -0.28 & 0.50 & -0.37 & 0.86 & 1.56 & 0.03 & 0.21 & 1.72 & 0.78 \\
\hline Rusk Creek & 1.22 & 0.23 & -0.83 & 1.17 & -0.40 & -1.23 & 0.55 & 0.85 & 1.05 & 0.78 \\
\hline Salt Creek & 1.22 & 1.07 & -0.93 & 0.86 & -0.98 & 0.34 & 0.44 & 1.09 & -0.45 & 0.78 \\
\hline Trappers Creek & -0.78 & -1.35 & 1.53 & -1.43 & 1.91 & -1.43 & -1.56 & -1.46 & 0.59 & -1.22 \\
\hline
\end{tabular}


The first step is to change the values of the predictor variables to standard normal form. This is because each variable is in a different form, and we need to be able to compare the values to each other (Davis, 2002). The equation for this process is Equation 5 , where $Z_{i}$ is standard normal form, $X_{i}$ is the initial value, $S$ is the standard deviation among the group of variables, and $\mathrm{X}$ is the mean of the values for that variable.

$$
Z_{i}=\frac{X_{i}-X}{\mathrm{~s}} \quad \text { Equation } 5
$$

The results of changing the variable values to standard normal form are found in Table 33. Now, using the standardized variable values we will use regression to determine the coefficient values for each variable. The regression was performed in Excel 2007. The results of this regression are shown in Table 34.

Now we need to use the Wald Test to determine the influence of each variable. Wald Values are reported for each regression in Table 35. After each regression, the variable with the lowest Wald Value or the least influence on the outcome is removed. The order in which each variable drops out is important; those that drop out first are less influential, and those that drop out last are more influential. The order of variable removal is also shown in Table 35. 
Table 34: Results of the initial regression, before any variables were removed.

\begin{tabular}{|c|c|c|c|c|c|c|c|c|}
\hline \multicolumn{2}{|c|}{ SUMMARY OUTPUT } & & & & & & & \\
\hline \multicolumn{2}{|c|}{ Regression Statistics } & & & & & & & \\
\hline Multiple R & 0.87 & & & & & & & \\
\hline R Square & 0.76 & & & & & & & \\
\hline Adjusted R & 0.50 & & & & & & & \\
\hline Standard & 0.71 & & & & & & & \\
\hline Observations & 18 & & & & & & & \\
\hline \multicolumn{9}{|l|}{ ANOVA } \\
\hline & $d f$ & SS & MS & $F$ & Significan & & & \\
\hline Regression & 9 & 13.00 & 1.44 & 2.89 & 0.08 & & & \\
\hline Residual & 8 & 4.00 & 0.50 & & & & & \\
\hline \multirow[t]{2}{*}{ Total } & 17 & 17 & & & & & & \\
\hline & $\begin{array}{c}\text { Coefficie } \\
\text { nts }\end{array}$ & $\begin{array}{c}\text { Standard } \\
\text { Error }\end{array}$ & $t$ Stat & $\begin{array}{c}P- \\
\text { value }\end{array}$ & $\begin{array}{c}\text { Lower } \\
95 \%\end{array}$ & $\begin{array}{l}\text { Upper } \\
95 \%\end{array}$ & $\begin{array}{l}\text { Lower } \\
95.0 \%\end{array}$ & $\begin{array}{l}\text { Upper } \\
95.0 \%\end{array}$ \\
\hline Intercept & $1.3 \mathrm{E}-16$ & 0.17 & $7.8 \mathrm{E}-$ & 1 & -0.38 & 0.38 & -0.38 & 0.38 \\
\hline $\mathrm{X} 1$ & 0.66 & 0.40 & 1.65 & 0.14 & -0.27 & 1.60 & -0.27 & 1.60 \\
\hline$x 2$ & 0.00 & 0.63 & 0.00 & 1.00 & -1.46 & 1.46 & -1.46 & 1.46 \\
\hline$x 3$ & -0.44 & 0.46 & -0.97 & 0.36 & -1.50 & 0.61 & -1.50 & 0.61 \\
\hline $\mathrm{X} 4$ & -0.29 & 0.41 & -0.72 & 0.49 & -1.23 & 0.65 & -1.23 & 0.65 \\
\hline X5 & -0.49 & 0.35 & -1.39 & 0.20 & -1.29 & 0.32 & -1.29 & 0.32 \\
\hline$x 6$ & -0.01 & 0.30 & -0.05 & 0.96 & -0.70 & 0.67 & -0.70 & 0.67 \\
\hline$x 7$ & 0.13 & 0.36 & 0.36 & 0.73 & -0.71 & 0.96 & -0.71 & 0.96 \\
\hline$x 8$ & 0.08 & 0.27 & 0.29 & 0.78 & -0.55 & 0.71 & -0.55 & 0.71 \\
\hline$\times 9$ & 0.33 & 0.48 & 0.69 & 0.51 & -0.78 & 1.45 & -0.78 & 1.45 \\
\hline
\end{tabular}


Table 35: Results of the Wald Test for the coefficients after each regression and subsequent removal of the least significant variable. Least significant value is shown in red for each regression.

\begin{tabular}{|c|c|c|c|c|c|c|c|}
\hline$\frac{5}{\frac{0}{y}}$ & \multicolumn{2}{|c|}{ Results } & $\begin{array}{c}\text { Variable } \\
\text { Removed } \\
\text { for next }\end{array}$ & $\begin{array}{l}.0 \\
\frac{.}{y} \\
\frac{d}{00}\end{array}$ & \multicolumn{2}{|c|}{ Results } & $\begin{array}{c}\text { Variable } \\
\text { Removed } \\
\text { for next }\end{array}$ \\
\hline \multirow{10}{*}{0} & Coefficient & Wald Value & \multirow{10}{*}{$\begin{array}{c}X_{3} \\
\text { \% Steep } \\
\text { Slopes }\end{array}$} & \multirow{10}{*}{4} & & & \multirow{10}{*}{$\begin{array}{c}\mathrm{X}_{6} \\
\text { Gradient } \\
\text { of the } \\
\text { upper } \\
\text { basin }\end{array}$} \\
\hline & $\mathrm{B}_{1}$ & 2.71 & & & & & \\
\hline & $\mathrm{B}_{2}$ & 2.707 & & & Coefficient & Wald Value & \\
\hline & $\mathrm{B}_{3}$ & 0.000 & & & $\mathrm{~B}_{1}$ & 3.59 & \\
\hline & $\mathrm{B}_{4}$ & 0.939 & & & $\mathrm{~B}_{2}$ & 1.97 & \\
\hline & $\mathrm{B}_{5}$ & 0.513 & & & $\mathrm{~B}_{5}$ & 2.05 & \\
\hline & $\mathrm{B}_{6}$ & 1.945 & & & $\mathrm{~B}_{6}$ & 0.67 & \\
\hline & $B_{7}$ & 0.002 & & & $\mathrm{~B}_{8}$ & 1.29 & \\
\hline & $\mathrm{B}_{8}$ & 0.126 & & & & & \\
\hline & $\mathrm{B}_{9}$ & 0.086 & & & & & \\
\hline \multirow{9}{*}{1} & Coefficien & Wald Value & \multirow{9}{*}{$\begin{array}{c}\mathrm{X}_{9} \\
\text { Connection } \\
\text { to glacier }\end{array}$} & \multirow{9}{*}{5} & & & \multirow{9}{*}{$\begin{array}{c}X_{8} \\
\text { Percent } \\
\text { Glacier } \\
\text { Area lost } \\
1904- \\
2006\end{array}$} \\
\hline & $\mathrm{B}_{1}$ & 1.834 & & & & & \\
\hline & $\mathrm{B}_{2}$ & 0.38 & & & Coefficient & Wald Value & \\
\hline & $\mathrm{B}_{4}$ & 0.185 & & & $\mathrm{~B}_{1}$ & 3.09 & \\
\hline & $\mathrm{B}_{5}$ & 1.038 & & & $\mathrm{~B}_{2}$ & 1.80 & \\
\hline & $\mathrm{B}_{6}$ & 0.509 & & & $\mathrm{~B}_{5}$ & 2.72 & \\
\hline & $\mathrm{B}_{7}$ & 0.192 & & & $\mathrm{~B}_{8}$ & 1.16 & \\
\hline & $\mathrm{B}_{8}$ & 0.890 & & & & & \\
\hline & $\mathrm{B}_{9}$ & 0.054 & & & & & \\
\hline \multirow{8}{*}{2} & Coefficient & Wald Value & \multirow{8}{*}{$\begin{array}{c}\mathrm{X}_{4} \\
\% \\
\text { Vegetation } \\
\text { in the } \\
\text { upper basin }\end{array}$} & \multirow{8}{*}{6} & & & \multirow{8}{*}{$\begin{array}{c}\mathrm{X}_{2} \\
\text { \% Bedrock } \\
\text { in the } \\
\text { upper } \\
\text { basin }\end{array}$} \\
\hline & $\mathrm{B}_{1}$ & 2.02 & & & & & \\
\hline & $\mathrm{B}_{2}$ & 1.88 & & & Coefficient & Wald Value & \\
\hline & $\mathrm{B}_{4}$ & 0.14 & & & $\mathrm{~B}_{1}$ & 4.93 & \\
\hline & $B_{5}$ & 1.09 & & & $\mathrm{~B}_{2}$ & 1.09 & \\
\hline & $\mathrm{B}_{6}$ & ].52 & & & $\mathrm{B}_{5}$ & 3.61 & \\
\hline & $B_{7}$ & 0.18 & & & & & \\
\hline & $\mathrm{B}_{8}$ & 1.30 & & & & & \\
\hline \multirow{7}{*}{3} & Coefficient & Wald Value & \multirow{7}{*}{$\begin{array}{c}\mathrm{X}_{7} \\
\mathrm{MRN}\end{array}$} & \multirow{7}{*}{7} & & & \\
\hline & $\mathrm{B}_{1}$ & 3.11 & & & & & \\
\hline & $\mathrm{B}_{2}$ & 1.92 & & & Coefficient & Wald 国alue & \\
\hline & $\mathrm{B}_{5}$ & 1.04 & & & $\mathrm{~B}_{1}$ & 27.90 & \\
\hline & $\mathrm{B}_{6}$ & 0.43 & & & $\mathrm{~B}_{5}$ & 3.10 & \\
\hline & $B_{7}$ & 0.09 & & & & & \\
\hline & $\mathrm{B}_{8}$ & 1.28 & & & & & \\
\hline
\end{tabular}


Table 36: Results of the final regression showing the coefficients for the last two predictor variables.

\begin{tabular}{|c|c|c|c|c|c|c|c|c|}
\hline \multicolumn{2}{|c|}{ Regression Statistics } & & & & & & & \\
\hline Multiple R & 0.82 & & & & & & & \\
\hline R Square & 0.66 & & & & & & & \\
\hline Adjusted R & 0.6 & & & & & & & \\
\hline Standard & 0.62 & & & & & & & \\
\hline Observations & 18 & & & & & & & \\
\hline \multicolumn{9}{|l|}{ ANOVA } \\
\hline & $d f$ & SS & $M S$ & $F$ & \multicolumn{2}{|c|}{ Significance $F$} & & \\
\hline Regression & 2 & 11.29 & 5.65 & 14.85 & \multicolumn{2}{|l|}{0.00} & & \\
\hline Residual & 15 & 5.71 & 0.38 & & & & & \\
\hline \multirow[t]{2}{*}{ Total } & 17 & 17 & & & & & & \\
\hline & $\begin{array}{c}\text { Coefficie } \\
n t s\end{array}$ & $\begin{array}{c}\text { Standard } \\
\text { Error }\end{array}$ & t Stat & $\begin{array}{c}- \\
\text { value }\end{array}$ & $\begin{array}{c}\text { Lower } \\
95 \%\end{array}$ & $\begin{array}{c}\text { Upper } \\
95 \%\end{array}$ & $\begin{array}{l}\text { Lower } \\
95.0 \%\end{array}$ & $\begin{array}{l}\text { Upper } \\
95.0 \%\end{array}$ \\
\hline Intercept & 0.00 & 0.15 & $1.3 \mathrm{E}-$ & 1 & -0.31 & 0.31 & -0.31 & 0.31 \\
\hline $\mathrm{X} 1$ & 0.79 & 0.15 & 5.28 & $9.2 \mathrm{E}-$ & 0.47 & 1.11 & 0.47 & 1.11 \\
\hline$\times 5$ & -0.26 & 0.15 & -1.76 & 0.10 & -0.58 & 0.06 & -0.58 & 0.06 \\
\hline
\end{tabular}

Now that we have the results of the multiple regression, we will use the logistic equation, Equation 6, to input our results.

$$
\theta=\frac{e^{\left(\alpha+\beta_{1} X_{1}+\beta_{2} X_{2}+\cdots+\beta_{n} X_{n}\right)}}{1+e^{\left(\alpha+\beta_{1} X_{1}+\beta_{2} X_{2}+\cdots+\beta_{n} X_{n}\right)}}
$$

Where $\alpha$ is the equation constant and $\beta$ is the coefficient calculated by the regression for each predictor variable, X (Hosmer \& Lemeshow, 1989; Pirot, 2010).

For our equation, predictor variables $X_{1}$ and $X_{5}$ were found to be significant contributors. Therefore, they will be used with their coefficients $\beta_{1}$ and $\beta_{5}$ to produce a model to best predict $Y$. The equation is now our model:

$$
Y=\frac{e^{\left(0+.79 X_{1}+-.26 X_{5}\right)}}{1+e^{\left(0+.79 X_{1}+-.26 X_{5}\right)}}
$$


To test the accuracy of our model, we will use it with our data to see how accurately it predicts the outcome $\mathrm{Y}$ (2006 debris flow occurrence). The results are shown in Table 37. Because we used a logistic regression, the outcome is very simple. The values yielded will be between 0 and 1 with drainages yielding values closer to 1 having a higher probability of debris flow occurrence.

Table 37: Results of the model (Equation 7) made by multiple logistic regression. Drainages with values higher than .5 are bolded. Known $Y$ is occurrence of debris flow as found by this study.

\begin{tabular}{|l|c|c|}
\hline & $\begin{array}{c}\text { Result of } \\
\text { Model }\end{array}$ & $\begin{array}{c}\text { Known Y (Debris } \\
\text { flow occurrence) }\end{array}$ \\
\hline Big Muddy & $\mathbf{0 . 8 0}$ & $\mathbf{1}$ \\
\hline Adams Creek & $\mathbf{0 . 8 0}$ & $\mathbf{1}$ \\
\hline Muddy Fork & $\mathbf{0 . 8 0}$ & $\mathbf{1}$ \\
\hline Salt Creek & $\mathbf{0 . 6 8}$ & $\mathbf{1}$ \\
\hline Rusk Creek & $\mathbf{0 . 6 2}$ & $\mathbf{1}$ \\
\hline Hellroaring & $\mathbf{0 . 5 6}$ & $\mathbf{0}$ \\
\hline East Fork & $\mathbf{0 . 5 6}$ & $\mathbf{0}$ \\
\hline Little Muddy & $\mathbf{0 . 5 4}$ & $\mathbf{1}$ \\
\hline Lewis Creek & $\mathbf{0 . 5 4}$ & $\mathbf{1}$ \\
\hline Cascade Creek & 0.40 & 0 \\
\hline Morrison Creek & 0.38 & 0 \\
\hline Crofton Creek & 0.35 & 0 \\
\hline Killen Creek & 0.35 & 0 \\
\hline Gotchen Creek & 0.35 & 0 \\
\hline Riley Creek & 0.35 & 0 \\
\hline Trappers Creek & 0.33 & 0 \\
\hline Bird Creek & 0.30 & 0 \\
\hline Horeshoe Creek & 0.22 & 0 \\
\hline
\end{tabular}

The results of the model are very good. The result of .5 or higher indicates a positive agreement, and those below .5 indicate a negative (Pirot, 2010). The model predicted a debris flow for 9 drainages, of which 7 actually had them. The model also predicted no debris flows for 9 drainages, none of which actually had them. That is an 
$89 \%$ accuracy rate. The two factors used for this model, as found by multiple logistic regression, were percent glacial coverage in the upper basin and average annual rainfall.

\subsubsection{Regression with combined Mt. Adams and Mt. Hood Data}

The results of this model are fairly promising, however, accuracy could be increased with more data. Pirot, (2010) did a logistic regression using almost identical basin attributes to predict debris flows on Mt. Hood in Oregon. Mt. Hood and Mt. Adams are both Cascade volcanoes with similar process and climates. Combing the basin attribute data from both of these mountains could produce a more accurate debris flow model that could be used for other Cascade volcanoes.

The attributes used by Pirot (2010) were rainfall amount, percent bedrock in the upper basin, percent vegetation in the upper basin, percent slopes above 33 degrees in the upper basin, gradient of the upper basin, connection to glacier, glacier area and MRN. Only attributes that can be correlated across both mountains can be used for the combined logistic regression. Rainfall amount cannot be used because for the Mt. Hood study, these data were storm data that represented actual rainfall during the November, 2006 storm. These data only exist for Mt. Adams above 10,000 ft, higher than most initiation sites, due to its distance from the Doppler Weather Radar Station used to obtain the NEXRAD data. Percent bedrock and glacier area in the upper basin cannot be used due to a difference in methods of collection between Mt. Adams and Mt. Hood. Percent vegetation, percent slopes above 33 degrees, gradient of the upper basin, connection to glacier and MRN can be used due to consistent methods of 
collection between the Mt. Hood study and this study. Percent glacier area lost between 1904 and 2006 was not used for the Pirot, (2010) study and cannot be used here because although glacier change data exists for 6 of the main glaciers on Mt. Hood (Jackson \& Fountain, 2007), there is not glacier change data across all drainages. Percent glacial coverage in the upper basin was not used for the Pirot, (2010) study but was calculated to be used here.

Table 38: Attributes and raw data for the combined multiple regression analysis.

\begin{tabular}{|c|c|c|c|c|c|c|c|}
\hline Raw Data & 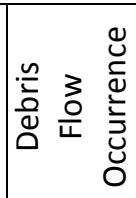 & 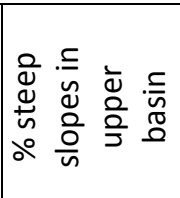 & 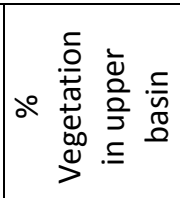 & 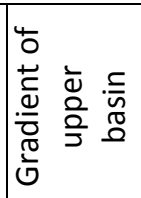 & 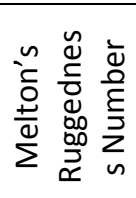 & 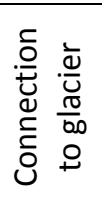 & 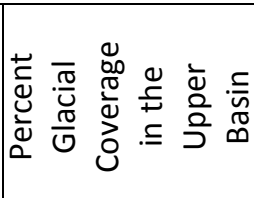 \\
\hline Drainage & $Y$ & $X_{1}$ & $x_{2}$ & $X_{3}$ & $X_{4}$ & $x_{5}$ & $X_{6}$ \\
\hline Adams Creek & 1 & 11 & 6 & 0.30 & 0.67 & 100 & 52 \\
\hline Big Muddy & 1 & 31 & 2 & 0.36 & 0.60 & 100 & 44 \\
\hline Bird Creek & 0 & 1 & 38 & 0.19 & 0.31 & 0 & 0 \\
\hline Cascade Creek & 0 & 11 & 6 & 0.37 & 0.78 & 100 & 19 \\
\hline Crofton Creek & 0 & 24 & 14 & 0.40 & 0.72 & 100 & 10 \\
\hline East Fork & 0 & 30 & 6 & 0.47 & 0.86 & 0 & 29 \\
\hline Gotchen Creek & 0 & 7 & 9 & 0.25 & 0.35 & 0 & 8 \\
\hline Hellroaring Creek & 0 & 16 & 29 & 0.29 & 0.49 & 100 & 22 \\
\hline Horeshoe & 0 & 8 & 0 & 0.36 & 0.80 & 0 & 6 \\
\hline Killen Creek & 0 & 3 & 18 & 0.23 & 0.43 & 0 & 11 \\
\hline lewis Creek & 1 & 8 & 9 & 0.29 & 0.61 & 100 & 31 \\
\hline Little Muddy & 1 & 8 & 44 & 0.30 & 0.47 & 100 & 18 \\
\hline Morrison Creek & 0 & 9 & 6 & 0.36 & 0.70 & 0 & 11 \\
\hline Muddy Fork & 1 & 20 & 0 & 0.62 & 0.42 & 100 & 49 \\
\hline Riley Creek & 0 & 10 & 28 & 0.34 & 0.63 & 100 & 17 \\
\hline Rusk Creek & 1 & 25 & 9 & 0.40 & 0.75 & 100 & 26 \\
\hline Salt Creek & 1 & 22 & 0 & 0.38 & 0.79 & 100 & 39 \\
\hline Trappers Creek & 0 & 0 & 44 & 0.18 & 0.34 & 0 & 0 \\
\hline Clark & 1 & 27 & 27 & 0.16 & 0.68 & 100 & 27 \\
\hline Coe & 0 & 10 & 25 & 0.25 & 0.53 & 100 & 40 \\
\hline Eliot & 1 & 18 & 4 & 0.23 & 0.85 & 100 & 38 \\
\hline Ladd & 1 & 11 & 14 & 0.19 & 0.33 & 100 & 30 \\
\hline Muddy & 0 & 12 & 32 & 0.30 & 0.70 & 100 & 34 \\
\hline Newton & 1 & 23 & 24 & 0.15 & 0.72 & 100 & 37 \\
\hline Polallie & 0 & 6 & 66 & 0.17 & 0.46 & 0 & 13 \\
\hline Salmon & 1 & 9 & 4 & 0.23 & 0.43 & 100 & 33 \\
\hline Sandy & 1 & 30 & 8 & 0.27 & 0.44 & 100 & 38 \\
\hline White & 1 & 42 & 2 & 0.18 & 0.75 & 100 & 24 \\
\hline Zig Zag & 0 & 46 & 16 & 0.25 & 0.40 & 0 & 25 \\
\hline
\end{tabular}


Data were collected for Mt. Hood using the same sources and methods as the Mt.

Adams data. The attributes that can be used for this combined logistic regression

analysis and their values are listed in Table 38. Table 39 lists the values used for the

combined regression after normalization

Table 39: Normalized data for the combined regression analysis.

\begin{tabular}{|c|c|c|c|c|c|c|c|}
\hline Drainage & $\mathrm{Y}$ & $\mathrm{X}_{1}$ & $x_{2}$ & $x_{3}$ & $\mathrm{X}_{4}$ & $X_{5}$ & $X_{6}$ \\
\hline Adams Creek & 1.02 & -0.46 & -0.69 & 0.08 & 0.50 & 0.66 & 1.91 \\
\hline Big Muddy & 1.02 & 1.26 & -0.92 & 0.68 & 0.09 & 0.66 & 1.34 \\
\hline Bird Creek & -0.95 & -1.31 & 1.32 & -0.95 & -1.60 & -1.46 & -1.77 \\
\hline Cascade Creek & -0.95 & -0.49 & -0.68 & 0.70 & 1.14 & 0.66 & -0.41 \\
\hline Crofton Creek & -0.95 & 0.63 & -0.18 & 1.02 & 0.79 & 0.66 & -1.07 \\
\hline East Fork & -0.95 & 1.14 & -0.64 & 1.67 & 1.57 & -1.46 & 0.25 \\
\hline Gotchen Creek & -0.95 & -0.79 & -0.46 & -0.36 & -1.35 & -1.46 & -1.18 \\
\hline Hellroaring Creek & -0.95 & -0.05 & 0.77 & -0.06 & -0.57 & 0.66 & -0.24 \\
\hline Horeshoe & -0.95 & -0.69 & -1.03 & 0.61 & 1.22 & -1.46 & -1.36 \\
\hline Killen Creek & -0.95 & -1.15 & 0.07 & -0.55 & -0.90 & -1.46 & -1.03 \\
\hline lewis Creek & 1.02 & -0.71 & -0.49 & -0.01 & 0.15 & 0.66 & 0.40 \\
\hline Little Muddy & 1.02 & -0.73 & 1.65 & 0.10 & -0.66 & 0.66 & -0.54 \\
\hline Morrison Creek & -0.95 & -0.65 & -0.69 & 0.64 & 0.67 & -1.46 & -0.99 \\
\hline Muddy Fork & 1.02 & 0.30 & -1.03 & 3.15 & -0.99 & 0.66 & 1.66 \\
\hline Riley Creek & -0.95 & -0.55 & 0.67 & 0.48 & 0.27 & 0.66 & -0.56 \\
\hline Rusk Creek & 1.02 & 0.70 & -0.49 & 0.98 & 0.92 & 0.66 & 0.02 \\
\hline Salt Creek & 1.02 & 0.45 & -1.03 & 0.88 & 1.17 & 0.66 & 0.97 \\
\hline Trappers Creek & -0.95 & -1.41 & 1.65 & -1.10 & -1.44 & -1.46 & -1.77 \\
\hline Clark & 1.02 & 0.90 & 0.62 & -1.26 & 0.54 & 0.66 & 0.15 \\
\hline Coe & -0.95 & -0.56 & 0.50 & -0.40 & -0.33 & 0.66 & 1.05 \\
\hline Eliot & 1.02 & 0.13 & -0.79 & -0.59 & 1.52 & 0.66 & 0.92 \\
\hline Ladd & 1.02 & -0.47 & -0.18 & -0.98 & -1.49 & 0.66 & 0.36 \\
\hline Muddy & -0.95 & -0.38 & 0.93 & 0.07 & 0.65 & 0.66 & 0.62 \\
\hline Newton & 1.02 & 0.56 & 0.44 & -1.36 & 0.77 & 0.66 & 0.81 \\
\hline Polallie & -0.95 & -0.90 & 3.01 & -1.17 & -0.73 & -1.46 & -0.88 \\
\hline Salmon & 1.02 & -0.64 & -0.79 & -0.59 & -0.91 & 0.66 & 0.53 \\
\hline Sandy & 1.02 & 1.16 & -0.54 & -0.21 & -0.85 & 0.66 & 0.93 \\
\hline White & 1.02 & 2.19 & -0.91 & -1.07 & 0.94 & 0.66 & -0.12 \\
\hline Zig Zag & -0.95 & 2.53 & -0.05 & -0.40 & -1.08 & -1.46 & 0.01 \\
\hline
\end{tabular}


Table 40 shows the results of the first combined regression, before any factors are taken out. Table 41 shows the Wald Values for each coefficient after each regression and the order in which variables were removed. Table 42 shows the final regression with the coefficients for the last two variables, connection to the glacier and percent glacial coverage in the upper basin. Our model from the combined data is Equation 8.

$$
Y=\frac{e^{\left(0+.38 X_{5}+.40 X_{6}\right)}}{1+e^{\left(0+.38 X_{5}+.40 X_{6}\right)}}
$$

Equation 8

Table 40: Result of the first regression of the combined Mt. Adams and Mt. Hood data, before any variables were removed.

\begin{tabular}{|c|c|c|c|c|c|c|c|c|}
\hline \multicolumn{2}{|c|}{ Regression Statistics } & & & & & & & \\
\hline Multiple R & 0.77 & & & & & & & \\
\hline R Square & 0.59 & & & & & & & \\
\hline Adjusted R & 0.48 & & & & & & & \\
\hline \multicolumn{9}{|l|}{ Standard } \\
\hline Error & 0.72 & & & & & & & \\
\hline Observations & 29 & & & & & & & \\
\hline \multicolumn{9}{|l|}{ ANOVA } \\
\hline & $d f$ & SS & MS & $F$ & Significo & ce $F$ & & \\
\hline Regression & 6 & 16.60 & 2.77 & 5.34 & 0.00 & & & \\
\hline Residual & 22 & 11.40 & 0.52 & & & & & \\
\hline \multirow[t]{2}{*}{ Total } & 28 & 28 & & & & & & \\
\hline & Coefficients & $\begin{array}{c}\text { Standard } \\
\text { Error }\end{array}$ & $\begin{array}{c}t \\
\text { Stat }\end{array}$ & $\begin{array}{c}P- \\
\text { value }\end{array}$ & $\begin{array}{c}\text { Lower } \\
95 \%\end{array}$ & $\begin{array}{l}\text { Upper } \\
95 \%\end{array}$ & $\begin{array}{l}\text { Lower } \\
95.0 \%\end{array}$ & $\begin{array}{l}\text { Upper } \\
95.0 \%\end{array}$ \\
\hline Intercept & $1.1 \mathrm{E}-16$ & 0.13 & $8.3 \mathrm{E}-$ & 1 & -0.28 & 0.28 & -0.28 & 0.28 \\
\hline $\mathrm{X} 1$ & 0.06 & 0.16 & 0.35 & 0.73 & -0.27 & 0.38 & -0.27 & 0.38 \\
\hline $\mathrm{x} 2$ & -0.27 & 0.18 & - & 0.15 & -0.64 & 0.10 & -0.64 & 0.10 \\
\hline $\mathrm{x} 3$ & -0.25 & 0.16 & - & 0.13 & -0.58 & 0.08 & -0.58 & 0.08 \\
\hline $\mathrm{X} 4$ & -0.13 & 0.16 & - & 0.42 & -0.46 & 0.20 & -0.46 & 0.20 \\
\hline $\mathrm{X} 5$ & 0.41 & 0.19 & 2.21 & 0.04 & 0.02 & 0.80 & 0.02 & 0.80 \\
\hline $\mathrm{x} 6$ & 0.34 & 0.20 & 1.65 & 0.11 & -0.09 & 0.76 & -0.09 & 0.76 \\
\hline
\end{tabular}


Table 41: Combined regression results of the Wald Test for the coefficients after each regression and subsequent removal of the least significant variable.

\begin{tabular}{|c|c|c|c|}
\hline Regression & & its & Variable Removed for next regression \\
\hline \multirow{7}{*}{0} & Coefficient & Wald Value & \multirow{7}{*}{$\begin{array}{c}\mathrm{X}_{1} \\
\text { Percent Steep Slopes in the Upper Basin }\end{array}$} \\
\hline & $\mathrm{B}_{1}$ & 0.12 & \\
\hline & $\mathrm{B}_{2}$ & 2.27 & \\
\hline & $\mathrm{B}_{3}$ & 2.49 & \\
\hline & $\mathrm{B}_{4}$ & 0.67 & \\
\hline & $\mathrm{B}_{5}$ & 4.87 & \\
\hline & $\mathrm{B}_{6}$ & 2.73 & \\
\hline \multirow{6}{*}{1} & Coefficient & Wald Value & \multirow{6}{*}{$\begin{array}{c}\mathrm{X}_{4} \\
\text { Melton's Ruggedness Number }\end{array}$} \\
\hline & $B_{2}$ & 2.72 & \\
\hline & $\mathrm{B}_{3}$ & 2.74 & \\
\hline & $\mathrm{B}_{4}$ & 0.61 & \\
\hline & $\mathrm{B}_{5}$ & 4.97 & \\
\hline & $\mathrm{B}_{6}$ & 3.41 & \\
\hline \multirow{5}{*}{2} & Coefficient & Wald Value & \multirow{5}{*}{$\begin{array}{l}\qquad \mathrm{X}_{2} \\
\text { Vegetation in the Upper Basin }\end{array}$} \\
\hline & $\mathrm{B}_{2}$ & 2.24 & \\
\hline & $\mathrm{B}_{3}$ & 3.22 & \\
\hline & $\mathrm{B}_{5}$ & 4.54 & \\
\hline & $\mathrm{B}_{6}$ & 3.77 & \\
\hline \multirow{4}{*}{3} & Coefficient & Wald Value & \multirow{4}{*}{$\begin{array}{c}\quad X_{3} \\
\text { Gradient }\end{array}$} \\
\hline & $\mathrm{B}_{3}$ & 1.57 & \\
\hline & $\mathrm{B}_{5}$ & 4.08 & \\
\hline & $\mathrm{B}_{6}$ & 6.07 & \\
\hline \multirow{3}{*}{4} & Coefficient & Wald Value & \\
\hline & $\mathrm{B}_{5}$ & 4.33 & \\
\hline & $\mathrm{B}_{6}$ & 4.88 & \\
\hline
\end{tabular}


Table 42: Results of the final regression showing the coefficients for the last two predictor variables for the combined Mt. Adams and Mt. Hood data. $X_{5}$ is connection to the glacier, and $X_{6}$ is percent glacial coverage in the upper basin.

\begin{tabular}{|c|c|c|c|c|c|c|c|c|}
\hline \multicolumn{2}{|c|}{ Regression Statistics } & & & & & & & \\
\hline Multiple R & 0.72 & & & & & & & \\
\hline \multicolumn{7}{|l|}{ Adjusted R } & & \\
\hline Square & 0.47 & & & & & & & \\
\hline \multicolumn{9}{|l|}{ Standard } \\
\hline Error & 0.73 & & & & & & & \\
\hline Observations & 29 & & & & & & & \\
\hline \multicolumn{9}{|l|}{ ANOVA } \\
\hline & $d f$ & SS & MS & $F$ & Significan & & & \\
\hline Regression & 2 & 14.33 & 7.16 & 13.62 & $9.0 \mathrm{E}-05$ & & & \\
\hline Residual & 26 & 13.67 & 0.53 & & & & & \\
\hline \multirow[t]{3}{*}{ Total } & 28 & 28 & & & & & & \\
\hline & Coefficie & Standard & & $P-$ & Lower & Upper & Lower & Upper \\
\hline & $n t s$ & Error & t Stat & value & $95 \%$ & $95 \%$ & $95.0 \%$ & $95.0 \%$ \\
\hline Intercept & $1.5 \mathrm{E}-17$ & 0.13 & $1.1 \mathrm{E}-$ & 1 & -0.28 & 0.28 & -0.28 & 0.28 \\
\hline$\times 5$ & 0.38 & 0.18 & 2.08 & 0.05 & 0.00 & 0.76 & 0.00 & 0.76 \\
\hline$x 6$ & 0.40 & 0.18 & 2.21 & 0.04 & 0.03 & 0.78 & 0.03 & 0.78 \\
\hline
\end{tabular}

To test our combined model we will use it with our data to see how accurately it predicts the outcome Y (2006 debris flow occurrence). Results are in table 43.

A result of .5 or higher indicates a positive agreement and a result of below .5 indicates a negative. The model predicted a debris flow for 19 drainages, of which only 14 actually had them. The model also predicted no debris flows for 10 drainages, of which 10 had none. That results in an $83 \%$ accuracy rate. The two factors used for this model were percent glacial coverage in the upper basin and connection to the glacier. 
Table 43: Results of the combined model with data from Mt. Adams and Mt. Hood. Drainages with values higher than .5 are bolded.

\begin{tabular}{|c|c|c|}
\hline Drainage & $\begin{array}{c}\text { Result of } \\
\text { Model }\end{array}$ & $Y$ \\
\hline Adams Creek & 0.74 & 1 \\
\hline Muddy Fork & 0.72 & 1 \\
\hline Big Muddy & 0.69 & 1 \\
\hline Coe & 0.66 & 0 \\
\hline Salt Creek & 0.66 & 1 \\
\hline Sandy & 0.65 & 1 \\
\hline Eliot & 0.65 & 1 \\
\hline Newton & 0.64 & 1 \\
\hline Muddy & 0.62 & 0 \\
\hline Salmon & 0.61 & 1 \\
\hline Lewis Creek & 0.60 & 1 \\
\hline Ladd & 0.60 & 1 \\
\hline Clark & 0.58 & 1 \\
\hline Rusk Creek & 0.56 & 1 \\
\hline White & 0.55 & 1 \\
\hline Hellroaring & 0.54 & 0 \\
\hline Cascade Creek & 0.52 & 0 \\
\hline Little Muddy & 0.51 & 1 \\
\hline Riley Creek & 0.51 & 0 \\
\hline Crofton Creek & 0.46 & 0 \\
\hline East Fork & 0.39 & 0 \\
\hline Zigzag & 0.37 & 0 \\
\hline Polallie & 0.29 & 0 \\
\hline Morrison Creek & 0.28 & 0 \\
\hline Killen Creek & 0.27 & 0 \\
\hline Gotchen Creek & 0.26 & 0 \\
\hline Horeshoe & 0.25 & 0 \\
\hline Trappers Creek & 0.22 & 0 \\
\hline Bird Creek & 0.22 & 0 \\
\hline
\end{tabular}

\subsection{Summary of results of statistical analysis}

Results were not completely consistent for the analysis of variance tests, the multiple logistic regression and the combined multiple logistic regression using additional data from Mt. Hood. Results are shown in Table 44. 
Table 44: Summary of statistical testing results for this study and for Pirot (2010).

\begin{tabular}{|c|c|c|}
\hline Method & Factors Found Important & Model Produced and Accuracy \\
\hline $\begin{array}{c}\text { Analysis of } \\
\text { Variance }\end{array}$ & $\begin{array}{c}\text { Upper basin Area } \\
\text { Percent Glacial Coverage in the Upper Basin } \\
\text { Area of Glacier in the Upper Basin } \\
\text { Percent Bedrock (Andesite, Basalt and } \\
\text { Dacite) in the upper basin } \\
\text { Distance from Glacier to Start of Stream }\end{array}$ & None \\
\hline $\begin{array}{c}\text { Multiple } \\
\text { Logistic } \\
\text { Regression }\end{array}$ & $\begin{array}{l}\text { (Listed in order of importance, with factors } \\
\text { deemed statistically important bolded) } \\
\text { 1. Percent Glacial Coverage in the upper } \\
\text { Basin } \\
\text { 2. Average Annual Rainfall } \\
\text { 3. Percent Bedrock (Andesite, Basalt and } \\
\text { Dacite) in the upper basin } \\
\text { 4. Percent Glacier Area Lost } 1904 \text { to } 2006 \\
\text { 5. Gradient of the Upper Basin } \\
\text { 6. Melton's Ruggedness number } \\
\text { 7. Percent Vegetation in the upper basin } \\
\text { 8. Connection to the Glacier } \\
\text { 9. Percent Steep Slopes in the upper Basin }\end{array}$ & $\begin{array}{c}Y=\frac{e^{\left(0+.79 X_{1}+-.26 X_{5}\right)}}{1+e^{\left(0+.79 X_{1}+-.2 X_{5}\right)}} \\
89 \% \text { Accurate for this study }\end{array}$ \\
\hline $\begin{array}{c}\text { Multiple } \\
\text { Logistic } \\
\text { Regression } \\
\text { using } \\
\text { addition data } \\
\text { from Mt. } \\
\text { Hood }\end{array}$ & $\begin{array}{l}\text { (Listed in order of importance, with factors } \\
\text { deemed statistically important bolded) } \\
\text { 1. Percent Glacial Coverage in the upper } \\
\text { Basin } \\
\text { 2. Connection to Glacier } \\
\text { 3. Percent Vegetation in the Upper Basin } \\
\text { 4. Gradient } \\
\text { 5. Percent Steep Slopes } \\
\text { 6. Melton's Ruggedness Number }\end{array}$ & $\begin{array}{c}Y=\frac{e^{\left(0+1 X_{1}+-.35 X_{7}\right)}}{1+e^{\left(0+1 X_{1}+-.35 X_{7}\right)}} \\
\text { 83\% Accurate combined for this study } \\
\text { and Pirot (2010). }\end{array}$ \\
\hline $\begin{array}{l}\text { Multiple } \\
\text { Logistic } \\
\text { Regression } \\
\text { on Mt. Hood } \\
\text { by Pirot } \\
\text { (2010) }\end{array}$ & $\begin{array}{l}\text { (Listed in order of importance, with factors } \\
\text { deemed statistically important bolded) } \\
\text { 1. Gradient } \\
\text { 2. Percent Vegetation in the Upper Basin } \\
\text { 3. Connection to Glacier } \\
\text { 4. Rainfall Amount } \\
\text { 5. Percent Bedrock in the Upper Basin } \\
\text { 6. Melton's Ruggedness Number } \\
\text { 7. Glacier Area in the Upper Basin } \\
\text { 8. Percent Steep Slopes in the upper basin }\end{array}$ & $\begin{array}{c}\theta=\frac{e^{\left(0+-.562 X_{3}+-.568 X_{5}+.346 X_{6}\right)}}{1+e^{\left(0+-.562 X_{3}+-.568 X_{5}+.346 X_{6}\right)}} \\
90 \% \text { Accurate for Pirot (2010). }\end{array}$ \\
\hline
\end{tabular}




\section{Chapter 6: Discussion}

\subsection{Limitations}

\subsubsection{Limitations of Analysis of Variance}

For this study, analysis of variance was performed in Excel 2007. This tool tests the variance of groups of samples to determine if they are derived from separate overall populations. A p value of .05 was the cutoff value for significance, meaning there was a $5 \%$ chance of a type I error. Limitations of this approach are that there are several assumptions made, including that each set of replicates is a random sample from different populations, each parent population is normally distributed, and that each parent population has the same variance (Davis, 2002). In addition, the test can tell you with a given certainty that the samples are from separate parent populations but it cannot tell you if they are from the same population. The test becomes more reliable as the number of samples increases (Davis, 2002). For this type of application, we are limited to a sample size equal to the number of drainages. Mt. Adams only has 18 drainages, far less than the ideal number for analysis of variance.

\subsubsection{Limitations of Multiple Logistic Regression}

The main limitations of regression are that we can determine relative relationship between factors and the outcome of a debris flow, but we cannot establish causation (Davis, 2002; Hill \& Lewicki, 2007). Correlation is still a valuable tool when trying to predict, but we must always be reminded that it does not imply cause. 
Logistic regression assumes that the probability of the outcome is linearly and additively related to the predictor variables on the logistic scale (Hill \& Lewicki, 2007). When, in reality, the factors could have any number of types of relationship to the outcome, and if they do, they may be thrown out early due to a low linear regression fit.

The number of variables related to the number of samples can be a limitation in multiple regression. It is recommended that you have at least 10 times the number of samples as the number of variables (Hill \& Lewicki, 2007). For this study that would have meant between 50 and 90 drainages, obviously impossible when that number is fixed for each mountain.

Logistic regression is known to tend towards over estimation of the probability when sample sizes are low (Hill \& Lewicki, 2007). For this study, this is better than under-estimating because when assessing hazards, it is better to over-estimate than under-estimate.

When testing the accuracy of the model, the best method would be to test it on data that were not used to create the model (Hill \& Lewicki, 2007). However, we do not have data of this type. Therefore, our accuracy is determined by testing against data that were used to create the model, which as a rule should be very high. The model should be tested on data from other mountains to determine its true accuracy. 


\subsubsection{Limitations of the Wald Test}

Using the Wald Test requires that the data be in a normalized format (Davis, 2002). Standard normal form was used for this study. This means that in order to use the resulting model with data that are not normalized it needs to be un-standardized. Therefore, the model produced by this study can only be used with normalized data.

\subsubsection{Limitations of Data}

The results of the statistical tests are only as good as the data used to perform them. All of the data were constrained to the boundaries of the drainages. The drainages were determined from dividing 12 digit hydrologic units by hand using a $10 \mathrm{~m}$ DEM. Boundaries could have been significantly different if different interpretations or decisions were made.

The samples used for the grain size analysis were very small. It is possible that with a small sample size a representative sample was not taken and the results of the grain size analysis are not accurate.

The rainfall data used were not storm data. Storm data come from Doppler Weather stations. Because of the distance from Mt. Adams to one of these stations, data were only available above $10,000 \mathrm{ft}$, which is higher than the areas of significance to this study. In addition, full coverage of the mountain is also not available, making comparing the data across the drainages impossible. Because of these issues, storm data were not used. Instead, average annual rainfall was used based on the possibility that average annual precipitation influences debris flow initiation. 
All elevation data were derived from a $10 \mathrm{~m}$ DEM which has a resolution of onethird arc-second, or about 10 meters. If LiDAR had been available results could have been more accurate. Percent steep slopes and percent vegetation were determined by hand outlining areas in ARCmap. These values could have been different if different interpretations or decisions were made. Some of the ages of the debris flows were determined by comparing orthophotographs. In many cases the ages of the debris flows were fairly obvious or outside sources confirmed their date, however in some cases interpretations were made that someone else may have made differently. The glacier data and the geologic data were obtained digitally from outside authors. Digital data can have differing sources of error due to creation, storage, and transfer methods. Arc Map was used to measure areas, lengths and heights of basins. Any error from this method would be due to error from creating the drainages or error from the DEM. Samples for the sieve analysis are subject to the human error resulting from collection, transport and measurement.

\subsection{Debris Flow Inventory}

The results of the initial inventory and collection of attributes for each drainage on Mt. Adams seemed to show few patterns. Debris flows occurred in 7 of the 18 drainages and were at first appeared to have occurred on all sides of the mountain. Cascade rainfall patterns usually produce more rain on the western side of the mountains causing more slope failures (Pirot, 2010). Further examination showed that six of the seven debris flow occurred on the north east half of the mountain. The 
SNOTEL sites showed more rainfall on the southwestern part of the mountain than on the north side, but debris flows concentrated on the side that had less rainfall and thereby suggest that more factors are in play than amount of rainfall. Even though there was more rainfall on the southwestern portion of the mountain, heavy rainfall was experienced on all sides of the mountain. The drainages on the southwestern side of the mountain also had many pre-2006 debris flows, and following standard Cascade weather patterns would have more rainfall during the year. This suggests that drainages on the southwestern side may be more likely to have a debris flow during any given year, but the drainages on the northeastern side of the mountain are more likely to have a debris flow given a large climatic trigger.

A landslide initiated one debris flow, three were initiated by heavy water flow and in channel landslides, and three were headless debris flows (Pirot, 2010). The initiation zones were all in areas mapped as Quaternary glacial drift suggesting that even in areas with roughly the same material, debris flows can initiate different ways.

The farthest traveling debris flow was the Big Muddy Creek debris flow attaining a distance of 11,600 m, followed closely by the Little Muddy Creek reaching 11,010 m. Other large debris flows were, Salt Creek, Muddy Fork and Rusk Creek, travelling 8,500, 6,180 and 5,400 m respectively. Debris flows that travelled smaller distances were Adams Creek, and Lewis Creek with 2,600 and 2,100 m respectively. However, length the debris flow travelled may not be the best way to measure size as this can be influenced by the morphology of the mountain. For example, the Adams Creek debris 
flow left one of the largest deposits but did not travel very far because a relatively flat area was present at a high elevation. The scope of the project did not include measurement of debris flow volume.

Initial difference in the percent bedrock (combined basalt, andesite and dacite), unconsolidated material (glacial drift and volcaniclastics), and glaciers in the upper basins seemed very significant. The biggest difference appeared to be percent bedrock, as basins with debris flows averaged $29 \%$ bedrock (with 35\% unconsolidated material and $37 \%$ glacial coverage) and basins without debris flows averaged $63 \%$ bedrock (with $25 \%$ unconsolidated material and $12 \%$ glacial coverage). This would make sense because to have a debris flow you need loose sediment that is easily transported, and basins with less bedrock would have more unconsolidated material (glacial drift and volcaniclastics). These basins would be described as transport limited, meaning they have plenty of sediment just waiting for the right climatic trigger to mobilize into a debris flow. The opposite would be weathering limited basins, where there is more hard rock that needs to be weathered in order to produce enough sediment to produce a debris flow. In general for this study it should seem that any basin that was transport limited should have experienced a debris flow in November, 2006 because it provided a large climatic event with lots of rainfall to mobilize sediment into a debris flow.

However, even with the large difference in percent bedrock in the upper basins, there was a smaller difference in percent unconsolidated material. Basins with debris flows did have a slightly higher (35\% unconsolidated material) than basins without 
debris flows ( $25 \%$ unconsolidated material), but the more important factor (as shown in the multiple logistic regression) was the percent glacial coverage. Basins with more glacial coverage in the upper basin were more likely to produce a debris flow. Drainages with debris flows averaged $37 \%$ glacial coverage and basins without debris flows only averaged $12 \%$. This is because although the storm produced lots of heavy rainfall, and there was extra water in all areas of the mountain, drainages with a large glacier above them received even more water as it ran off the glaciers. Glaciers acted as an impermeable surface, funneling more water into the drainages below them, causing slope failures and debris flows. Drainages with little glacial coverage in their upper basins were more able to absorb the water caused by rainfall because they did not have extra water running off the glaciers to deal with. Bedrock outcrops are also impermeable surfaces, and can increase runoff rates. Bedrock, as it was measured for this study, however, is simply what was mapped as andesite, basalt or dacite from the geologic map. These bedrock units may not actually be impermeable, as mapping practices allow for areas to be mapped as a bedrock unit even if they are not a solid bedrock outcrop.

However, this does not mean that receding glaciers will decrease debris flow activity. This storm occurred in early November, 2006 before significant snow had fallen in the Cascades. Snow cover, if it is significant instead of the small amount that was present for this storm, can act as a water barrier. It can absorb and slow down water movement into the streams. Receding glaciers and climate change could be coupled 
with less and later snowfall in the mountains. This would result in more exposed loose sediment as the glaciers uncover it, and less protective snow fall and more destructive rainfall, suggesting higher frequencies of debris flows (Burns et al., 2009).

In agreement with the idea that larger glacial coverage in upper basins produces more debris flows were the data for change in glacier area from 1904 to 2006 and 1998 to 2006 and the percent glacial change from 1904 to 2006. Surprisingly again, drainages with debris flows averaged $41 \%$ glacial loss and drainages without averaged $52 \%$. A small difference, and this correlation was only seen in the percent loss, as the total area loss was higher for debris flow producing basins for both year intervals.

Percent steep slopes, percent vegetation, average annual rainfall, gradient and MRN all had different average values for the debris flow groups and the non-debris flow groups but none of the raw values suggested anything significant. MRN was above .3 for all basins, indicating that they could all be capable of producing a debris flow.

Turning the focus to values instead of percentages for several of the basin attributes can give us some information about thresholds. Looking at area glacial coverage in the upper basin, basins with debris flows averaged $2.3 \mathrm{~km}^{2}$ and ranged from $3.5 \mathrm{~km}^{2}$ to $1.3 \mathrm{~km}^{2}$ while basins without debris flows averaged $0.6 \mathrm{~km}^{2}$ and ranged from $0 \mathrm{~km}^{2}$ to $1.6 \mathrm{~km}^{2}$. No debris flows occurred in basins with less than $1.3 \mathrm{~km}^{2}$ of glacial coverage in the upper basin. For upper basin area, basins with debris flows averaged 7.0 $\mathrm{km}^{2}$ and ranged from $4.8 \mathrm{~km}^{2}$ to $10.0 \mathrm{~km}^{2}$ while basins without debris flows averaged 4.3 
$\mathrm{km}^{2}$ and ranged from $3.0 \mathrm{~km}^{2}$ to $7.6 \mathrm{~km}^{2}$. No debris flows occurred in basins with an area of less than $4.9 \mathrm{~km}^{2}$.

\subsection{Statistical Tests}

\subsubsection{Analysis of Variance}

The results of the analysis of variance were not very surprising. Very few factors were determined to have significantly different means. This is most likely a result of the small sample size, a point which will be visited later in this section. These factors were upper basin area, percent glacial coverage in the upper basin, area of glacier in the upper basin, percent bedrock (andesite, basalt and dacite) in the upper basin, and distance from a glacier to the start of the stream. Basin area is logical as the larger basins would have a larger catchment area to collect water. Percent glacial coverage in the upper basin, area of glacier in the upper basin and distance from a glacier to the start of stream are also logical. These findings confirm conclusions assumed based on the initial value differences in the raw data. Basins with more glacial coverage most likely had excess water to manage because glaciers acted as impermeable surfaces funneling water directly to streams. Percent bedrock is also a confirmation of assumed conclusions from raw data. Bedrock is not easily weathered or mobilized into a debris flow. Basins with more bedrock are less likely to have experienced a debris flow. 


\subsubsection{Multiple Logistic Regression}

The results of the multiple logistic regression were interesting. The data for Mt. Adams produced a model that put the most emphasis on percent glacial coverage in the upper basin and then secondary emphasis on average annual rainfall. The percent glacial coverage was not unexpected as it was assumed important based on the raw data, and confirmed to be statistically significant by analysis of variance. The result of average annual rainfall was not anticipated. Initial values seemed to have little influence, and it was not determined to have significantly different means between the debris flow and non-debris flow groups by analysis of variance. Also of note is the negative in the coefficient. This meant that basins with less average annual rainfall were more likely to have experienced a debris flow in November, 2006. This is in agreement with the fact that six of the seven debris flows occurred on the northeast side of the mountain. This side of the mountain is dryer during the year, and these basins that get less rainfall are less accustomed to accommodating rainfall, and their runoff rates are higher meaning more water is being channeled into streams. This could also be because basins with less rainfall experience less erosion during the year and therefore have more unconsolidated sediments stored in their upper basins to be mobilized when a large climactic event occurs. These basins would also have undeveloped sub-surface runoff pathways, forcing more water to runoff on the surface.

The multiple logistic regression using additional data from Mt. Hood from Pirot (2010) produced results that could have been expected. The model produced 
emphasized two factors almost equally. First was percent glacial coverage in the upper basin, not surprising as it was deemed important by all the tests for Mt. Adams and had it been used in the same way for the Mt. Hood study it probably would have been found significant. Second was connection to the glacier. This result was not entirely unexpected because it was found important by Pirot (2010) and would shorten the amount of time for rain to enter the stream, meaning the stream would have more water to accommodate in a shorter amount of time. For the Mt. Adams data, however, it was determined to have significantly different means for the debris flow and nondebris flow groups by the analysis of variance, but it was very early to drop out of the regression. This suggests that it is an important factor in the initiation of debris flows but was less important for the storm of November, 2006 at Mt. Adams.

\subsubsection{Summary of Statistics}

Looking at the statistical tests performed on the Mt. Adams data, several things become clear. First, the different approaches to determine correlation produce different results. Factors that were not able to be determined to have significantly different means between debris flow drainages and non debris flow drainages ended up being significant contributors to the outcome of a debris flow in the logistic regression. Several issues could be contributing to this problem. First is the number of 'samples' which in this case is the number of drainages. Increasing the sample size can greatly increase the accuracy of all statistic tests. This study is limited at 18 samples because we can only have one measurement of each attribute per drainage. 
In an attempt to overcome this problem, the data were combined with close to identical types of data for Mt. Hood from Pirot (2010). However, the results of the combined logistic regression showed slightly less accurate results. The reasons for this could be slight differences in data collection and interpretation, or it could be different factors have different influences at the different mountains. However, when looking at each different approach of data analysis, patterns are visible, Table 44. Percent glacial coverage in the upper basin was determined important for all the statistic tests on the Mt. Adams data and for the combined multiple regression with data from Mt. Hood. Connection to the glacier was determined to have significantly different variances for the debris flow and non debris flow groups in the analysis of variance. It was early to drop out for the multiple regression on Mt. Adams data but determined to be significant in both the combined multiple regression and the multiple regression for Mt. Hood data. Other factors that are high on most of the lists include gradient and percent vegetation. A factor that was high on the list for Mt. Adams and not used for Mt. Hood was percent glacier lost between 1904 and 2006.

It is important to see that each mountain's separate model predicted it's debris flows with higher accuracy than when the data is combined. Accuracy went from $89 \%$ and $90 \%$ down to $83 \%$ when the data was combined. This suggests that each mountain might have slightly different factors contributing to debris flow generation. On Mt. Adams, \% glacial coverage and average annual rainfall were most important and on Mt. Hood, gradient, percent vegetation in the upper basin and connection to glacier were 
most important. The specific models for each mountain are more accurate for their locations, but they may not be more accurate for mountains without data in this study. If data from more mountains were included, it would be easier to tease out which factors are important across all Cascade volcanoes

The debris flows used for this study all occurred during one storm. Historical debris flows were not taken into account. If instead of using YES and NO for the Y value in the logistic regression I used a factor relating to the recurrence interval of debris flows in each drainage we could produce a model yielding which drainages are more likely to produce a debris flow in any given year, as drainages with higher debris flow recurrence intervals would be more likely to produce a debris flow any time. This study focused on one storm and the debris flows it produced. Therefore, the results of this study is a model that generates a likelihood of a debris flow occurring in a drainage with given attributes given the right climatic trigger. 


\section{Chapter 7: Conclusions}

In early November, 2006 a large "Pineapple Express," or MJO, storm caused debris flows in 7 of 18 drainages on Mt. Adams. Basins with debris flows were Adams Creek, Big Muddy Creek, Lewis Creek, Little Muddy Creek, Muddy Fork, Rusk Creek, and Salt Creek. Of these seven debris flows, a landslide initiated one, three were initiated by heavy water flow and in-channel landslides, and three were initiated by a coalescence of eroded channels (headless debris flows). Salt Creek was landslide initiated; Adams Creek, Lewis Creek, and Muddy Fork were initiated by in-channel landslides caused by increased water flow; and headless debris flows occurred in Big Muddy Creek, Little Muddy Creek, and Rusk Creek drainages.

The farthest traveling debris flow was the Big Muddy Creek debris flow attaining a distance of 11,600 m, followed closely by the Little Muddy Creek reaching 11,010 m. Other large debris flows were, Salt Creek, Muddy Fork and Rusk Creek, travelling 8,500, 6,180 and 5,400 m respectively. Debris flows that travelled smaller distances were Adams Creek, and Lewis Creek with 3,900 and 2,600 m respectively.

Debris flows dated prior to 2006 were found in Cascade Creek, Crofton Creek, Hellroaring Creek and Morrison Creek. These debris flows were not dated but appeared to be recent. Figure 84 is an inventory map including the 2006 debris flows and the older debris flows. 


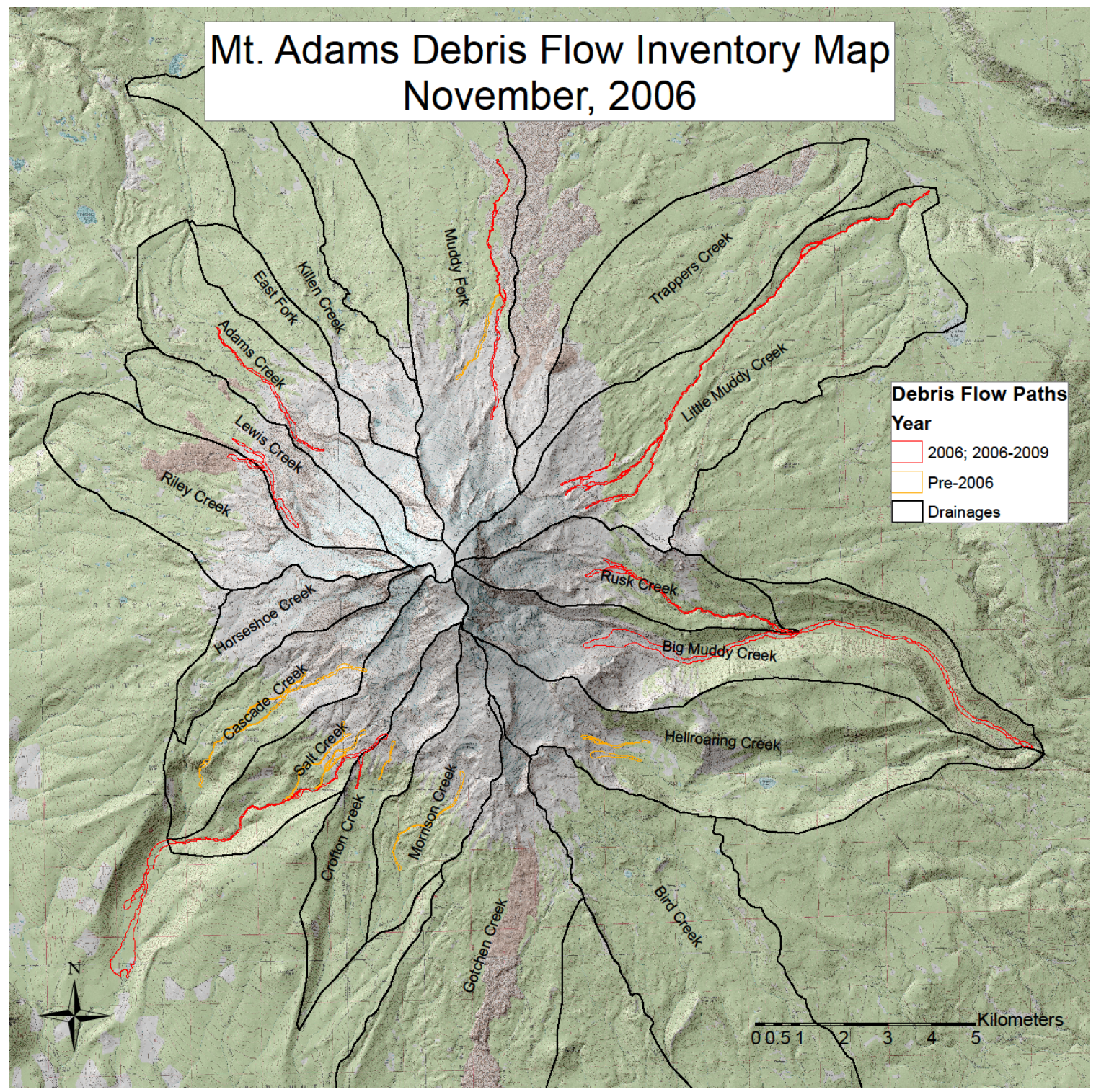

Figure 84: Debris Flow Inventory Map for Mt. Adams.

Each debris flow that occurred at Mt. Adams in early November of 2006 initiated in an area mapped as Quaternary glacial drift (Department of Natural Resources, 2005).

The elevations of the initiation zones were all very similar, ranging from 2,140 m to $2,320 \mathrm{~m}$ with an average value of $2,209 \mathrm{~m} \pm .83$. 
Melton's Ruggedness Number was above .3 for all basins on Mt. Adams, implying each of them is capable of producing a debris flow (Jackson et al., 1987).

The upper basins of drainages with debris flows averaged $37 \%$ glacial coverage, $29 \%$ bedrock and $35 \%$ unconsolidated material. The upper basins of drainages without debris flows without averaged $12 \%$ glacial coverage, $63 \%$ bedrock, and $25 \%$ unconsolidated material.

All of the drainages with debris flows were directly connected to the glacier, opposed to only $36 \%$ of the drainages without debris flows.

Drainages with debris flows averaged $18 \%$ slopes above $33^{\circ}, 10 \%$ vegetation, a gradient of 0.38 , a MRN of 0.62 , an average annual rainfall of $2.16 \mathrm{~m}$, and $-52 \%$ glacier lost between 1904-2006. The upper basins of drainages without debris flows averaged $11 \%$ slopes above $33^{\circ}, 18 \%$ vegetation, a gradient of 0.31 , a MRN of 0.58 , an average annual rainfall of $2.38 \mathrm{~m}$, and $-41 \%$ glacier lost between 1904-2006.

Grain size analysis was performed on 29 samples from 11 different areas on Mt. Adams. There was no significant difference in grain size between samples taken from debris flow initiation sites in basins that experienced a 2006 debris flow from elevations similar to other debris flow initiation size in basins that did not experience a 2006 debris flow. Average values from the grain size analysis for the debris flow and non-debris flow basins are listed in Table 45. 
No debris flows occurred in basins with less than $1.3 \mathrm{~km}^{2}$ of glacial coverage in the upper basin.

No debris flows occurred in basins with an area of less than $4.9 \mathrm{~km}^{2}$

Table 45: Overall grain size analysis results grouped by occurrence of 2006 debris flow.

\begin{tabular}{|c|c|c|c|}
\hline $\begin{array}{c}\text { Debris } \\
\text { Flow }\end{array}$ & \% Gravel & \% Sand & \% Silt\&Clay \\
\hline NO & $30.2 \pm .16(12.7-46.5)$ & $68.3 \pm .15(52.7-85.5)$ & $1.1 \pm .01(.3-2.1)$ \\
\hline YES & $34.5 \pm .13(31.0-47.6)$ & $64.4 \pm .13(51.3-72.4)$ & $1.1 \pm .007(.5-1.5)$ \\
\hline
\end{tabular}

Analysis of variance showed that the following attributes had significantly different means between debris flow and non debris flow basins:

- Upper basin area

- Percent glacial coverage in the upper basin

- Area glacial coverage in the upper basin

- Percent bedrock (andesite, basalt and dacite) in the upper basin

- Distance from the glacier to start of the stream.

Multiple logistic regression showed that the following attributes were significant contributors to the outcome of a debris flow. They are listed in order of importance:

1. Percent glacial coverage in the upper basin

2. Average annual rainfall 
Multiple logistic regression eliminated the following attributes. Those listed first showed a higher influence and those listed last showed the least influence.

1. Percent bedrock (andesite, dacite, and basalt) in the upper basin

2. Percent glacier area lost 1904 to 2006

3. Gradient of the upper basin

4. Melton's Ruggedness Number (MRN)

5. Percent vegetation in the upper basin

6. Connection to the glacier

7. Percent steep slopes in the upper basin

Of the factors determined significant by multiple logistic regression, percent glacial coverage is directly proportional to debris flow occurrence and average annual rainfall in inversely proportional to debris flow occurrence.

The debris flow model resulting from the multiple logistic regression is:

$$
Y=\frac{e^{\left(0+.79 X_{1}+-.26 X_{5}\right)}}{1+e^{\left(0+.79 X_{1}+-.26 X_{5}\right)}}
$$

where $X_{1}$ is percent glacial coverage in the upper basin and $X_{5}$ is average annual rainfall, in standard normal form, and $Y$ is the probability of a basin with those attributes producing a debris flow given a climatic event similar to the storm of November, 2006. 
The Debris Flow Hazard Map for Mt. Adams based on this model is Figure 85.

This map was created by using the debris flow model equation (Equation 7) with the attributes for each basin. The values produced were divided into four groups: $<37 \%$ very low, 38-51\% low, 52-66\% moderate, and 67-80\% high. The hazard map colored these divisions from green to red, with green indicating very low, light green indicating low, yellow indicating moderate, orange indicating high and red indicating very high.

Models produced by multiple regression separately for Mt. Adams and Mt. Hood (Pirot, 2010) were more accurate at predicting their 2006 debris flows then when the data were combined. Accuracy went from $89 \%$ and $90 \%$ to $83 \%$. 


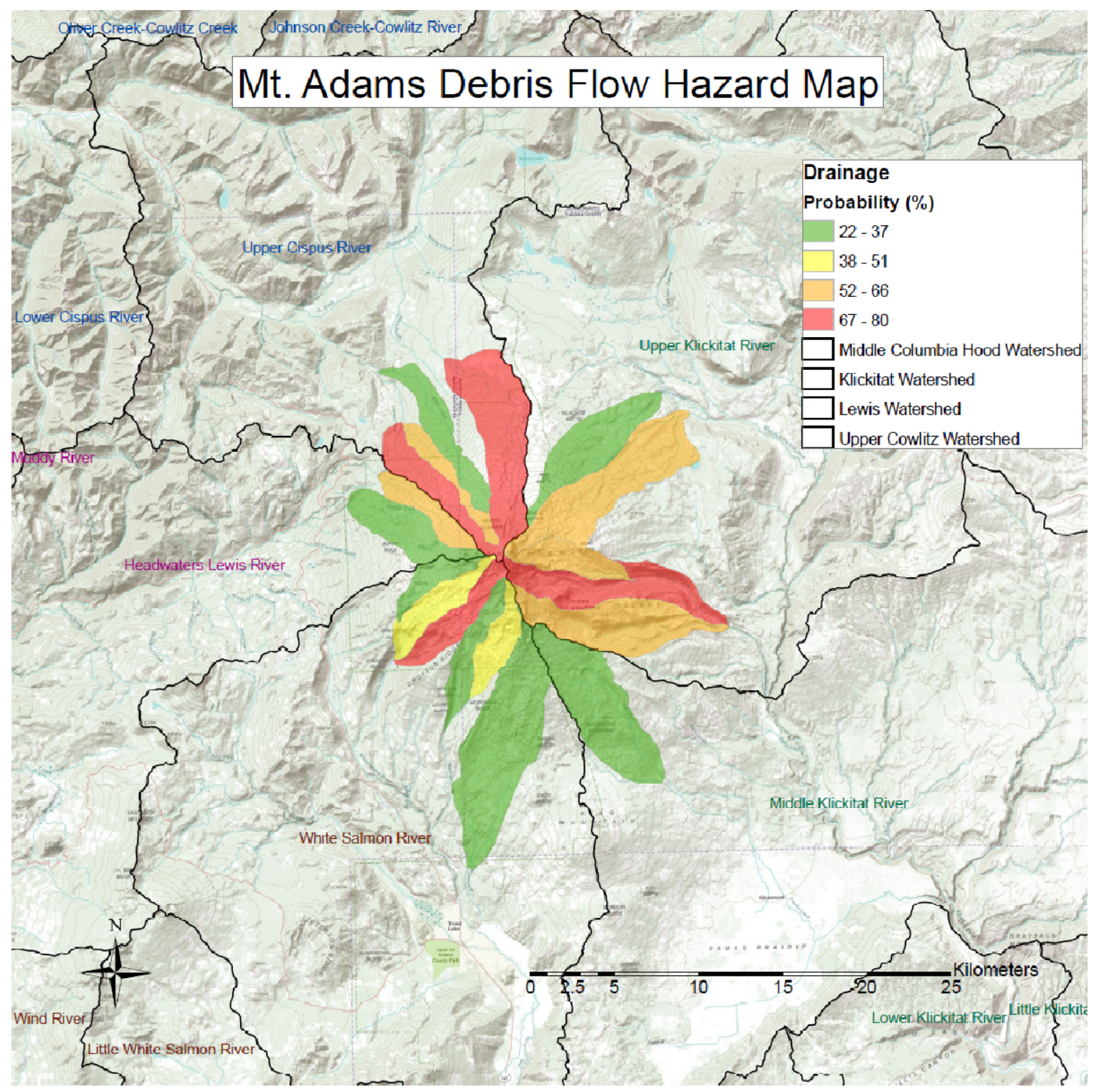

Figure 85: Debris Flow Hazard Map for Mt. Adams produced by logistic regression model. 


\section{Chapter 8: Future Work}

Although this project has produced conclusions, it has also raised several questions. The fact that different factors are significant contributors to debris flow occurrence at Mt. Adams and Mt. Hood suggest that either different process occur at each mountain or that a larger sample size would have found more consistent results. Repeating the logistic regression with more Cascade Mountain drainages could be an area of future work.

This project investigated debris flows that occurred as a result of a single storm. Several studies have previously shown the importance of recurrence intervals for debris flow producing basins. Using historical data to assign a recurrence interval attribute for the drainages and using that value instead of a 'YES' or 'NO' $\mathrm{Y}$ value in a logistic regression could yield a model more able to predict debris flows at any given time instead of predicting debris flows given a drainage and storm conditions similar to that of 2006.

The attributes used for the multiple logistic regression used percent coverage, when it may be more significant to look at the actual values. Repeating a multiple regression with absolute values for glacial coverage, amount of unconsolidated material, vegetation, and steep slopes may give a better insight into conditions needed to produce a debris flow.

Once the data and model were obtained for this thesis, the work of imputing values and applying symbology to produce the inventory and hazard maps was fairly 
cumbersome. This could have been made easier by creating a model with ArcGis so that other hazard maps could be made by simply inputting drainage polygons with attribute fields needed for the model. 


\section{Works Cited}

ASTM (1990). Method for particle-size analysis of soils. American society for testing and materials, Annual book of ASTM standards, sec. 4, v. 04.08, ASTM Designation D 422-63.

Bond, N. (2006) 2006 Record November Rainfall. Office of the Washington State Climatologist. Retrieved May 19, 2011 from www.climage.washington.edu/events/2006NovRain.html.

Bovis, M.J., \& Jakob, M. (1999). The role of debris supply conditions in predicting debris flow activity. Earth Surface Processes and Landforms, v. 24, p. 1039-1054.

Burns, Scott F., Pirot, R.P., Sobieszcyk, S., \& Williams, K. (2009). Massive debris flow events on Pacific Northwest volcanoes, November, 2006; as the climate changes, more debris flow events to come. Geological Society of America annual meeting Portland, Abstracts With Programs, vol. 41, No. 7, p. 716.

Cannon, S. H., Gartner, J. E., Rupert, M. G., \& Michael, J. A. (2003). Emergency Assessment of Debris-Flow Hazards from Basins Burned by the Grand Prix and Old Fires of 2003, Southern California. U.S. Department of the Interior, U.S. Geological Survey, Open-File Report of-03-475, 14 p.

Cannon, S. H., Gartner, J. E., Rupert, M. G., \& Michael, J. A. (2007). Methods for the Emergency Assessment of Debris-Flow Hazards from Basins Burned by the Fires of 2007, Southern California. U.S. Department of the Interior, U.S. Geological Survey, Open-File Report 2007-1384, 10 p.

Coe, J. A., Godt, J.W., Parise, M., \& Moscariello, A. (2003). Estimating debris-flow probability using fan stratigraphy, historic records, and drainage-basin morphology, Interstate 70 highway corridor, central Colorado, U.S.A. In: D. Rickenmann, \& C. Chen (Eds.), Debris-Flow Hazards Mitigation: Mehchanics, Prediction and Assessment. Rotterdam: Millpress p. 1085-1096.

Copeland, E. A. (2009). Recent Periglacial Debris Flows From Mount Rainier, Washington. MA Thesis, Oregon State University, Oregon. Print.

Davis, J. C. (2002). Statistics and Data Analysis in Geology, Third Edition. New York: John Wiley \& Sons, Inc. 
Department of Natural Resources, Washington Division of Geology and Earth Resources Staff (2005). Digital 1:100,000-scale Geology of Washington State, Version 1.0. Open File Report 2005-3.

Fannin, R.J., \& Wise, M.P. (2001). An empirical-statistical model for debris flow travel distance. Canadian Geotechnical Journal v. 38, p. 982-994.

Godt, J. W., \& Coe, J. A. (2007). Alpine Debris flows triggered by a 28 July 1999 thunderstorm in the central Front Range, Colorado. Geomorphology, v. 84, p. 80-97.

Gottschalck, J., Kousky, V., Higgins, W., \& L'Heureux, M. (2005). Madden Julian Oscillation (MJO) Summary. National Weather Service Climate Prediction Center. Retrieved May 19, 2011, from www.cpc.ncep.noaa.gov/products/precip/CWlink/MJO/MJO_summary.pdf

Hildreth, W., \& Fierstein, J. (1997). Recent eruptions of Mount Adams, Washington Cascades, USA. Bulletin of Volcanology, v. 58, p. 472-490.

Hildreth, W., \& Lanphere M. A. (1994). Potassium-argon geochronology of a basaltandesite-dacite arc system: The Mount Adams volcanic field, Cascade Range of southern Washington. Geological Society of America Bulletin, v. 106, p. 1413-1429.

Hill, T. \& Lewicki, P. (2007). Statistics Methods and Applications. Statsoft, Tulsa, OK.

Hoblitt, R.P., Miller, C. D., Scott W. E. (1987). Volcanic Hazards with Regard to Siting Nuclear-Power Plants in the Pacific Northwest. U.S. Geological Survey Open-File Report 87-297, 11 p.

Hosmer, D. W., \& Lemshow, S. (1989). Applied Logistic Regression. New York: John Wiley \& Sons, Inc.

Iverson, R. M., Schilling, S. P., \& Vallance, J.W. (1998). Objective delineation of laharinundation hazard zones. Geological Society of America Bulletin, v. 110, p. 972-984.

Iverson, R.M. (1997). The physics of debris flows. Reviews of Geophysics, p. 245-296.

Jackson, K. M., Fountain, A. G. (2007). Spatial and morphological change on Eliot Glacier, Mount Hood Oregon, USA. Annals of Glaciology, 46, p. 222-226.

Jackson, L. E., Kostaschuk, R. A., \& MacDonald, G. M. (1987) Identification of debris flow hazard on alluvial fans in the Canadian Rocky Mountains. In J. E. Costa, \& G. F. 
Wieczorek (Eds.), Debris Flows/Avalanches; Process, Recognition and Mitigation. Reviews in Engineering Geology, v. VII. Geological Society of America, p. 115-124.

Jakob, M., Bovis, M., \& Oden, M. (2005). The significance of channel recharge rates for estimating debris-flow magnitude and frequency. Earth Surface Processes and Landforms v. 30, p. 755-766.

Lloyd, Darryl (2007) Personal Communication. Long Shadow Photography, 1025 State Street Hood River, OR 97031.

Melton, M. A. (1965). The geomorphic and paleoclimatic significance of alluvial deposits in southern Arizona. Journal of Geology, v. 73, p. 1-38.

National Agriculture Imagery Program (NAIP) (2006) \& (2009). USDA-FSA-APFO Digital Ortho Mosaic.Quadrangle Orthophoto digital files.

Olson, Keith (2011). Analysis of Debris Flow Hazards for Mount St. Helens, Washington Based on the Major Rainfall Event of November 6-9, 2006. In: Proceedings of the Oregon Academy of Science.; February 26, 2011; Portland Community College, Sylvania, v. 70, p. 40.

Pierson, T. C. (2005). Distinguishing between debris flows and floods from field evidence in small watersheds. U.S. Geological Survey, USGS Fact Sheet 2004-3142, 4 p.

Pierson, T. C., Janda R. J., Thouret J-C., \& Borrero, C. A. (1990) Perturbation and melting of snow and ice by the 13 November 1985 eruption of Nevado del Ruiz, Colombia, and consequent mobilization, flow and deposition of lahars. Journal of Volcanology and Geothermal Research, v. 41, p. 17-66.

Pierson, T.C., \& Scott, K. M. (1985) Downstream dilution of a lahar: transition from debris flow to hyperconcentrated streamflow. Water Resources Research, v. 21, p. 1511-1524.

Pirot, R. (2010) Initiation Zone Characterization of Debris Flows in November, 2006, Mount Hood, Oregon. MA Thesis, Portland State University, Oregon. Print.

Scott, W. E., Iverson, R. M., Vallance, J. W., and Hildreth, W., (1995). Volcano Hazards in the Mount Adams Region, Washington. U.S. Geological Survey Open-File Report 95492, $11 p$. 
Sherrod, D. R., \& Smith, J. G. (1990). Quaternary extrusion rates of the Cascade Range, Northwestern United States and Southern British Columbia. Journal of Geophysical Research, v. 95, p. 19,465-19,474.

Sitts, D. J., Fountain, A. G., \& Hoffman, M. J. (2010). Twentieth Century glacier change on Mount Adams, Washington, USA. Northwest Science v. 84(4), p. 378-385.

Sobieszczyk, S., Uhrich, M. A., Piatt, D. R., \& Bragg, H. M. (2008). Analysis of geomorphic and hydrologic characteristics of Mount Jefferson debris flow, Oregon, November 6, 2006. U.S. Geologic Survey Scientific Investigations Report 2008-5204.

Topinka, L. (1997). Major Cascade Range Volcanoes of Washington, Oregon, and Northern California. USGS/CVO. Retrieved June 30, 2011, from http://vulcan.wr.usgs.gov/Volcanoes/Cascades/Maps/map_cascades_locationmap. html.

USDA Forest Service (March, 29 2007). Storm Damage Affects Visitor Access for Forest. Press Release. Retrieved May 19, 2011 from www.fs.fed.us/gpnf/news/2007/20070329a-forest-access-storm-damage.shtml.

US Forest Service, Gifford Pinchot National Forest (2008). Existing vegetation stands digital file. Retrieved August 4, 2011, from http://www.fs.fed.us/r6/datalibrary/gis/gifford-pinchot/index.shtml

Vallance, J. W. (1999). Postglacial lahars and potential hazards in the White Salmon River System on the Southwest Flank of Mount Adams, Washington. U.S. Geologic Survey Bulletin 2161.

Walder, J. S., \& Driedger, C. L. (1994). Geomorphic change caused by outburst floods and debris flows at Mount Rainier, Washington, with emphasis on Tahoma Creek valey. U.S. Geological Survey Open-File Report 93-4093, p. 3.

Willford, D. J., Sakals, M. E., Innes, J. L., Sidle, R. C., \& Bergerud, W.A. (2004). Recognition of debris flow, debris flood and flood hazard through watershed morphometrics. Landslides, v. 1, p. 61-66. 


\section{Appendix: SNOTEL data}

\begin{tabular}{|c|c|c|c|}
\hline Site Id & Date & Precipitation Accumulation & Precipitation Per Day \\
\hline 804 & $11 / 1 / 2006$ & 3.1 & 3.1 \\
\hline 804 & $11 / 2 / 2006$ & 3.3 & 0.2 \\
\hline 804 & $11 / 3 / 2006$ & 4.3 & 1 \\
\hline 804 & $11 / 4 / 2006$ & 6.8 & 2.5 \\
\hline 804 & $11 / 5 / 2006$ & 8.7 & 1.9 \\
\hline 804 & $11 / 6 / 2006$ & 11.4 & 2.7 \\
\hline 804 & $11 / 7 / 2006$ & 18.2 & 6.8 \\
\hline 804 & $11 / 8 / 2006$ & 21.7 & 3.5 \\
\hline 804 & $11 / 9 / 2006$ & 22.4 & 0.7 \\
\hline 804 & $11 / 10 / 2006$ & 23 & 0.6 \\
\hline 804 & $11 / 11 / 2006$ & 24.2 & 1.2 \\
\hline 804 & $11 / 12 / 2006$ & 25 & 0.8 \\
\hline 804 & $11 / 13 / 2006$ & 26.3 & 1.3 \\
\hline 804 & $11 / 14 / 2006$ & 28.1 & 1.8 \\
\hline 804 & $11 / 15 / 2006$ & 28.2 & 0.1 \\
\hline 702 & $11 / 1 / 2006$ & 2.4 & 2.4 \\
\hline 702 & $11 / 2 / 2006$ & 2.4 & 0 \\
\hline 702 & $11 / 3 / 2006$ & 3.6 & 1.2 \\
\hline 702 & $11 / 4 / 2006$ & 5.2 & 1.6 \\
\hline 702 & $11 / 5 / 2006$ & 7.1 & 1.9 \\
\hline 702 & $11 / 6 / 2006$ & 8.2 & 1.1 \\
\hline 702 & $11 / 7 / 2006$ & 12.1 & 3.9 \\
\hline 702 & $11 / 8 / 2006$ & 14.1 & 2 \\
\hline 702 & $11 / 9 / 2006$ & 14.5 & 0.4 \\
\hline 702 & $11 / 10 / 2006$ & 14.6 & 0.1 \\
\hline 702 & $11 / 11 / 2006$ & 15.7 & 1.1 \\
\hline 702 & $11 / 12 / 2006$ & 16.3 & 0.6 \\
\hline 702 & $11 / 13 / 2006$ & 17.3 & 1 \\
\hline 702 & $11 / 14 / 2006$ & 18.3 & 1 \\
\hline 702 & $11 / 15 / 2006$ & 18.3 & 0 \\
\hline 599 & $11 / 1 / 2006$ & 0.7 & 0.7 \\
\hline 599 & $11 / 2 / 2006$ & 0.7 & 0 \\
\hline 599 & $11 / 3 / 2006$ & 1 & 0.3 \\
\hline 599 & $11 / 4 / 2006$ & 1.2 & 0.2 \\
\hline
\end{tabular}




\begin{tabular}{|c|c|c|c|}
\hline 599 & $11 / 5 / 2006$ & 1.7 & 0.5 \\
\hline 599 & $11 / 6 / 2006$ & 2.4 & 0.7 \\
\hline 599 & $11 / 7 / 2006$ & 4.8 & 2.4 \\
\hline 599 & $11 / 8 / 2006$ & 6.7 & 1.9 \\
\hline 599 & $11 / 9 / 2006$ & 7 & 0.3 \\
\hline 599 & $11 / 10 / 2006$ & 7 & 0 \\
\hline 599 & $11 / 11 / 2006$ & 7.3 & 0.3 \\
\hline 599 & $11 / 12 / 2006$ & 7.4 & 0.1 \\
\hline 599 & $11 / 13 / 2006$ & 8.1 & 0.7 \\
\hline 599 & $11 / 14 / 2006$ & 8.4 & 0.3 \\
\hline 599 & $11 / 15 / 2006$ & 8.4 & 0 \\
\hline
\end{tabular}

